



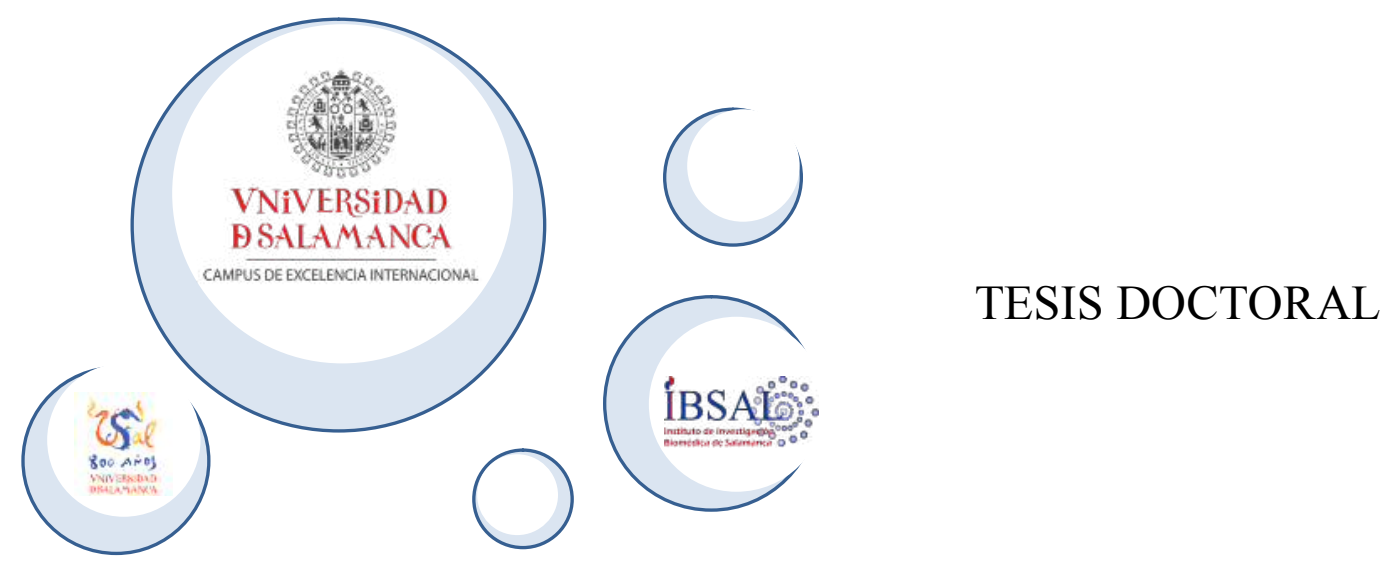

\section{ESTUDIO DE LA CAPACIDAD TERAPÉUTICA DE LAS CÉLULAS MESENQUIMALES ADMINISTRADAS POR VÍA SUBCONJUNTIVAL EN EL TRATAMIENTO DE LA ENFERMEDAD INJERTO CONTRA RECEPTOR OCULAR EN UN MODELO MURINO OPTIMIZADO}

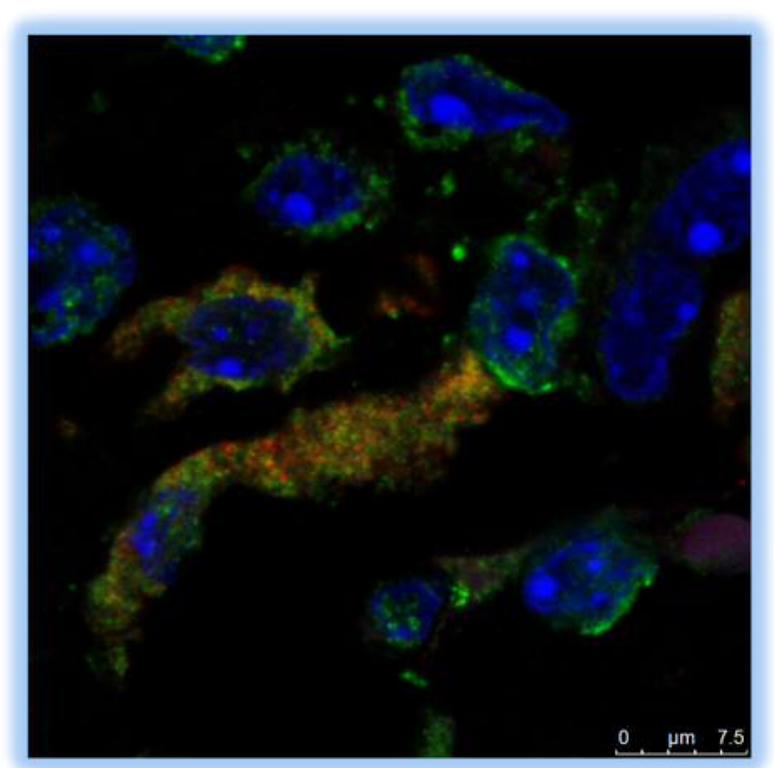

Facultad de Medicina

Departamento de Cirugía

Elisabet Martín García 2017 

Dr. D. Emiliano Hernández Galilea, Doctor en Medicina y Cirugía. Profesor titular de Oftalmología de la Universidad de Salamanca.

Dr. D Fermín Sánchez-Guijo Martín, Doctor en Medicina y Cirugía. Profesor asociado de Hematología y Hemoterapia de la Universidad de Salamanca (USAL) y responsable del Área de Terapia Celular y Hematopoyesis del Servicio de Hematología del Hospital Universitario de Salamanca (HUS).

Dr. D. Luis Ignacio Sánchez-Abarca Bernal, Doctor en Farmacia e Investigador Postdoctoral en la Fundación Investigación del Cáncer de la Universidad de Salamanca (IBMCC).

\section{CERTIFICAN:}

Que el presente trabajo titulado "ESTUDIO DE LA CAPACIDAD TERAPÉUTICA DE LAS CÉLULAS MESENQUIMALES ADMINISTRADAS POR VÍA SUBCONJUNTIVAL EN EL TRATAMIENTO DE LA ENFERMEDAD INJERTO CONTRA RECEPTOR OCULAR EN UN MODELO MURINO OPTIMIZADO" realizado por Dña. Elisabet Martín García, bajo su dirección en el Departamento de Cirugía, reúne, a su juicio, todos los requisitos y méritos exigidos para ser presentado ante el tribunal correspondiente y optar al Grado de Doctor por la Universidad de Salamanca. 



\section{AGRADECIMIENTOS}

Deseo expresar mi agradecimiento a todas aquellas personas e instituciones que de una u otra forma han hecho posible la elaboración de esta tesis doctoral.

Al Dr. Emiliano Hernández Galilea por darme la oportunidad de contactar con el mundo de la investigación y confiar en mí para desarrollar este proyecto. Además, me ha contagiado el entusiasmo y la pasión por la oftalmología, por lo que siempre será para mi un referente tanto profesional como docente.

Al Dr. Fermín Sánchez-Guijo por su respeto y su profesionalidad en todo momento. Ha contribuido en la dirección y en la consecución del proyecto. Me ha transmitido la serenidad, la positividad y la tranquilidad necesaria para que lleguen los éxitos en investigación.

Al Dr. Luis Ignacio Sánchez-Abarca, o simplemente Nacho, que ha sido mi pilar fundamental a lo largo de todo el proceso. Me llevo a un AMIGO que ha logrado sacar lo mejor de mí en cada momento y siempre me ha apoyado en lo profesional y en lo personal. Ha integrado en mí, con sus consejos, su paciencia y optimismo el verdadero sentido de la investigación.

Al Dr. Aijón por acceder de forma desinteresada a ser mi tutor durante todo este periodo.

A la Dra. Cañizo, por aceptarme en su laboratorio y permitirme trabajar y aprender en su magnífico grupo de investigación, todo un referente a nivel nacional e internacional.

Al Dr. Ángel Santos-Briz por su tiempo, sus importantes aportaciones a este proyecto, su amabilidad e inmensa generosidad. 
A María Ángeles, Inés Franco, Fernando Prieto, Ana Sánchez-Jara, Lourdes, Rebeca Lorenzo, Paco León, Santiago García, Ángel Bustos, Ángel Beltrán, Álvaro Casado, Daniel Ramos, Isabel Gómez, Rebeca Castro, Dori, Gumer, Cristina Cañete, Vanesa, Paco Escudero e Isabel Jiménez; mis maestros y referentes. Me han acompañado a lo largo de mis años de residencia. A todos ellos los admiro y admiraré el resto de mi vida tanto profesional como humanamente. Tienen el mérito de haberme levantado siempre que he tropezado, y han logrado gracias a su trabajo, esfuerzo y paciencia (especialmente en la cirugía) que hoy sea la especialista que soy. Nunca sabré como agradeceros vuestro tiempo invertido.

A todos mis residentes mayores, a los de mi año y a los residentes pequeños que han confiado en mí, siempre han estado dispuestos a ayudarme y de los que he aprendido muchísimo y de los que sin duda me queda mucho por aprender. Estoy segura de que serán grandes profesionales y personas.

A Mayte y Maritina que han sido mis segundas madres en el Servicio de Oftalmología, que en todo momento están dispuestas a ayudar sin perder nunca la sonrisa.

A Teresita, Ana y Rafa sin cuya experiencia, conocimientos y ayuda desinteresada no hubiera sido capaz de terminar este trabajo.

Al laboratorio de Cultivos y Terapia Celular del Servicio de Hematología, Conchi, Rebeca, Silvia, Ana, Sandra, Belén... que me han hecho sentir como una más y me han acogido con tanto cariño en el laboratorio.

A mis amigos, a los que estáis ahí y que sé, que siempre estaréis, porque nos une un gran cariño, y porque sois los primeros a la hora de ahogar penas o compartir alegrías. 
A mi familia y especialmente a Ignacio y Rosario, médicos y doctores extraordinarios, todo un referente para mi. Ellos tienen parte de culpa de que sea oftalmóloga y me han hecho tía del sobrino más bonito que una puede tener y del cual sentirse orgullosa, sí tú, pequeño Rodrigo.

A Luis Miguel, el mejor compañero con el que desde hace unos años comparto este largo viaje llamado vida y con el que tengo perspectivas de crear nuevos y grandes proyectos personales. Sin ti no sería una mujer completa, gracias por compartir todo conmigo, por comprenderme, por creer en mí de forma incondicional desde el principio y por no dejarme tirar la toalla jamás, por muy profundo que fuera el bache. Te quiero. Pase lo que pase, juntos hasta el final.

Y finalmente a mis padres, todo se lo debo a ellos, mis mentores y mi inspiración de todos y cada uno de los segundos de mi vida desde que nací. Sois mi principio y mi fin, porque sin vosotros no estaría aquí y sin vosotros no puedo vivir. Gracias por guiarme, apoyarme, aconsejarme y siempre y en todo momento estar ahí. Juntos hemos conseguido todo lo que nos hemos propuesto, somos invencibles. Un verdadero lujo ser vuestra hija; antes, ahora y siempre. Os quiero muchísimo. 

"El único verdadero viaje de descubrimiento consiste no en buscar nuevos paisajes sino en mirar con nuevos ojos."

Marcel Proust (1871-1922) 

Índice

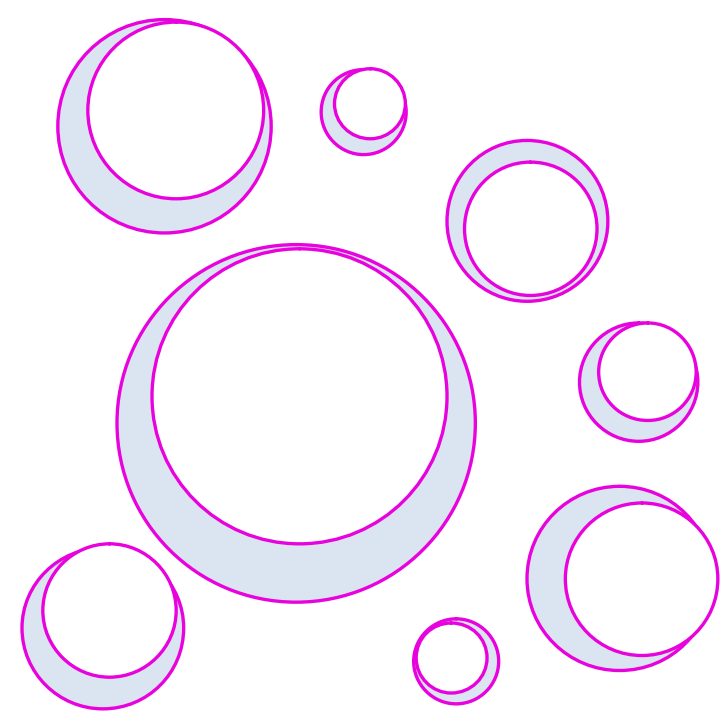



1. Anatomía del sistema visual y anejos____ 19

1.1. El globo ocular___ 19

1.2. Los párpados 20

1.3. La conjuntiva__ 26

1.4. Vía lagrimal __ 32

1.5. La película lagrimal ___ 34

2. Enfermedad injerto contra receptor (EICR) ___ 37

2.1. Clasificación de la EICR ___ 38

2.2. Fisiopatología de la EICR _ 39

2.2.1. EICR aguda__ 40

2.2.2. EICR Crónica

2.3. Manifestaciones clínicas de la EICR__ 43

2.4. Criterios de respuesta al tratamiento en la EICR __ 48

3. Enfermedad injerto contra receptor ocular (EICRo) ___ 50

3.1. Fisiopatología _— 50

3.2. Manifestaciones clínicas de la EICRo __ 61

3.2.1. Superficie ocular __ 62

3.3. Estrategias terapéuticas actuales en la EICRo____ 67

3.3.1. Lubricación y conservación de la lágrima ___ 67

3.3.2. Reducción de la carga inflamatoria de la superficie ocular___ 68

3.3.3. Soporte del epitelio corneal __ 70

3.3.4. Prevención de la evaporación lagrimal ___ 73

3.3.5. Tratamiento sistémico de la EICRo ___ 73

4. Células estromales mesenquimales _ 75

4.1. Caracterización y cultivo de las CSM__ 75

4.2. Potencial de diferenciación de las CSM _ 76

4.3. Funcionalidad de las CSM _ 77

4.4. Aplicaciones clínicas de las CSM en el contexto del trasplante hematopoyético____ 78

4.4.1. Aplicación en citopenias y EICR aguda __ 79

4.4.2. Reparación de las CSM en un modelo de ojo seco secundario a EICR __ 80

5. Importancia de la vía de administración en el tratamiento de las enfermedades oculares y en terapia celular ____ 82

5.1. Vías de administración oftalmológica_____ 82

5.2. Vías de administración de la terapia celular____ 83

2. Hipótesis y Objetivos ___ 85

3. Material y Métodos ___________ 89

3.1. Material _____ 91

3.1.1. Animales de experimentación ___ 91

3.1.2. Obtención de células estromales mesenquimales para cultivo____ 91

3.1.3. Material no biológico ___ 92

3.2. Métodos ___ 97

3.2.1. Modelo murino de generación de EICRo _________ 97

3.2.1.1. Células empleadas en el trasplante ___ 98

3.2.1.2. Irradiación _ 98

3.2.1.3. Trasplante__ 99

3.2.1.4. Evolución del quimerismo post-trasplante mediante citometría de flujo ____ 100

3.2.2. Obtención, aislamiento, expansión y transducción de CSM ___ 102 
3.2.2.1. Obtención de la MO

3.2.2.2. Separación de CMN

3.2.2.3. Cultivo y expansión de CSM

3.2.2.4. Caracterización inmunofenotípica de las CSM___ 103

3.2.2.5. Diferenciación de CSM 105

3.2.2.6. Transducción de las CSM _ 107

3.2.3. Administración de CSM __ 109

3.2.3.1. Administración tópica ___ 109

3.2.3.2. Administración subconjuntival____ 109

3.2.4. Extracción de los ojos, la glándula lagrimal y el párpado____ 110

3.2.5. Procesamiento histológico para microscopía óptica ___ 111

3.2.6. Técnicas inmunohistoquímicas ___ 113

3.2.7. Técnica de la citología de impresión ___ 117

3.2.8. Animales con EICR _ـ 117

3.2.8.1. Monitorización de la EICR __ 117

3.2.8.2. Monitorización de la EICRo __ 118

3.2.8.3. Experimento murino ___ 119

3.2.8.4. Modelo de punto final ___ 123

3.2.9. Fluorescencia y luminiscencia ___ 123

3.2.9.1. Bioluminiscencia___ 124

3.2.9.2. Análisis de la bioluminiscencia in vivo ___ 126

3.2.10. Medida de la producción de lágrima. Prueba del rojo fenol (PRT) ___ 127

3.2.11. Osmolaridad de la película lagrimal_____ 128

3.2.12. Infiltración linfocitaria de la glándula lagrimal en ratones BALB/c con EICRo_____ 130

4. Resultados

4.1. Modelo de generación de la EICRo

4.2. Animales con EICRo. Análisis clínico y anatomopatológico del párpado y de la glándula lagrimal

4.2.1. Signos clínicos de EICR y EICRo ___ 135

4.2.2. Examen anatomopatológico de la superficie ocular en el modelo de EICRo____ 139

4.2.2.1. Examen histológico mediante hematoxilina ___ 139

4.2.2.2. Examen histológico mediante PAS-azul alcian del párpado_____ 144

4.2.2.3. Examen histológico de la conjuntiva tarsal mediante caspasas $3 \ldots 145$

4.2.2.4. Examen histológico mediante citología de impresión conjuntival_____ 146

4.3. Análisis de las variaciones en la producción de lágrima ___ 147

4.4. Osmolaridad de la película lagrimal _______ 148

4.5. Transducción de las CSM ___ 149

4.6. Animales control tratados con inyección subconjuntival de CSM. Análisis Inmunohistoquímico de la glándula lagrimal y del párpado 153

4.6.1. Análisis Inmunohistoquímico de la glándula lagrimal control __ 153

4.6.2. Análisis Inmunohistoquímico del párpado control ___ 154

\subsection{Animales con EICRo tratados con inyección subconjuntival de CSM. Análisis} Inmunohistoquímico de la glándula lagrimal y del párpado

4.7.1. Análisis Inmunohistoquímico de la presencia de células $\mathrm{GFP}^{+}$inyectadas subconjuntivalmente en glándula lagrimal de ratones con EICRo 155

4.7.2. Análisis Inmunohistoquímico de la presencia de células GFP ${ }^{+}$inyectadas subconjuntivalmente en el párpado de ratones con EICRo

4.8. Análisis de la infiltración de etiología inflamatoria en la glándula lagrimal de la población afectada por EICR mediante citometría de flujo 
4.9. Diferenciación de las poblaciones que constituyen el infiltrado linfoide de etiología inflamatoria en glándulas lagrimales de ratones con EICRo 161

4.10. Efecto ejercido por las hCSM administradas por vía subconjuntival frente a la EICRo

4.10.1. Análisis clínico de la afectación ocular. Monitorización 162

4.10.2. Examen histológico mediante hematoxilina-eosina de la glándula lagrimal tratada mediante inyección subconjuntival de hCSM

4.10.3. Examen histológico mediante hematoxilina-eosina del párpado tratado mediante inyección subconjuntival de hCSM

4.10.4. Análisis de las variaciones en la producción de lágrima 165

4.10.5. Análisis de las variaciones en la osmolaridad de la película lagrimal ___ 166

4.10.6. Alteración en el tamaño y granularidad de la glándula lagrimal 167

5. Discusión

5.1. Optimización del modelo murino de ojo seco secundario a EICR

5.2. Administración subconjuntival de las hCSM

5.3. Efecto terapéutico de la administración subconjuntival de hCSM en un modelo de EICRo 181

5.3.1. CSM y regeneración

5.3.2. Inflamación y CSM

5.3.3. Correlación entre la actividad inflamatoria y la eficacia de la terapia con hCSM 



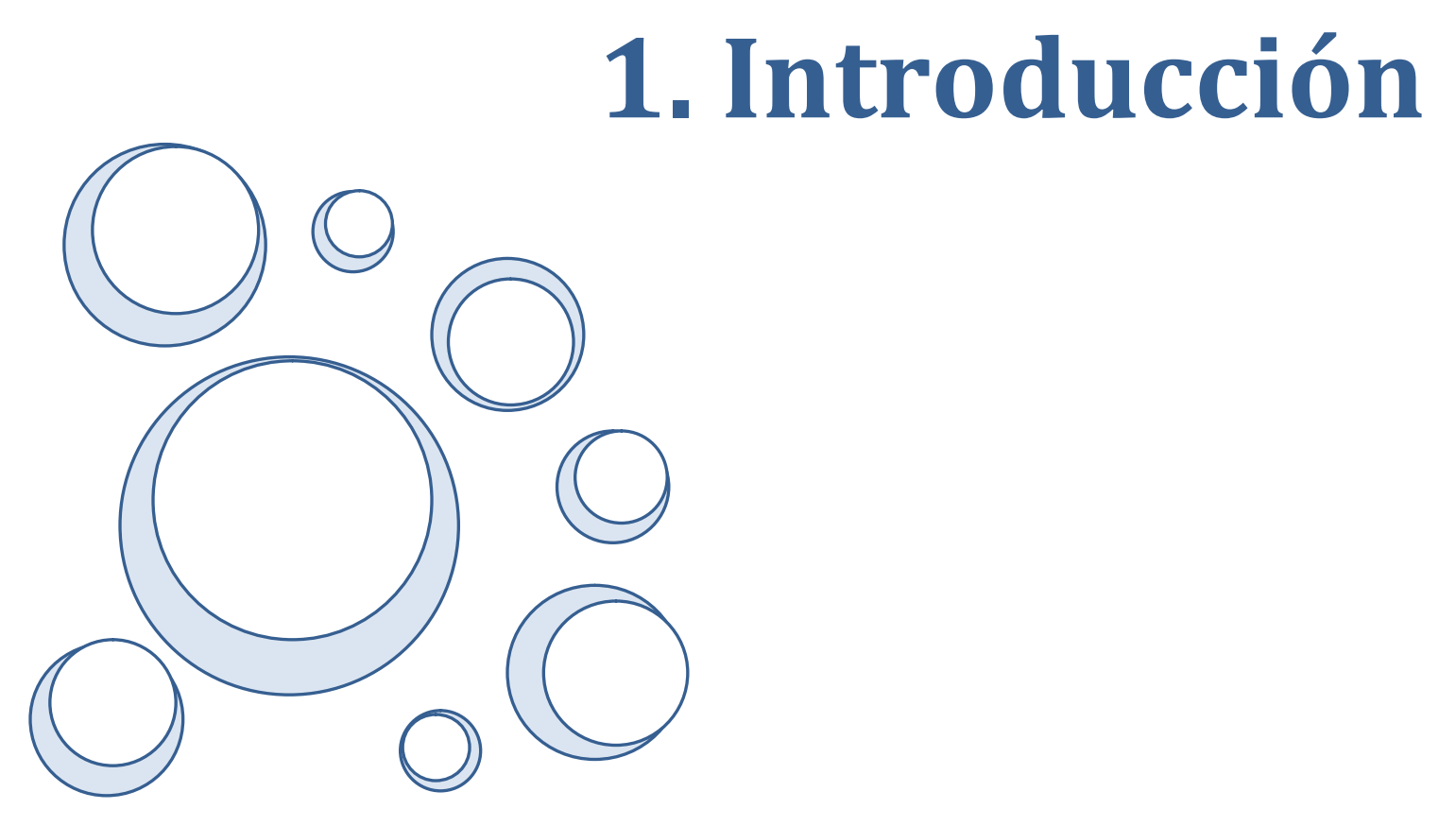





\section{ANATOMÍA DEL SISTEMA VISUAL Y ANEJOS}

\subsection{El globo ocular}

Es el elemento fundamental del órgano de la visión y se caracteriza por ser irregularmente esférico pues su parte anterior, constituida por la córnea, posee un radio de curvatura más corto que el resto del globo ocular.

El globo se compone de una pared y de un contenido. La pared está formada por tres capas concéntricas, que son de fuera a adentro la esclera que se continúa anteriormente con la córnea, la úvea y la retina. El contenido consta del cristalino, el humor acuoso y el cuerpo vítreo

La esclera o esclerótica es una membrana resistente e inextensible que adopta la forma del ojo. Constituye las cinco sextas partes posteriores de la capa fibrosa del globo ocular. La superficie externa de la esclera es lisa y blanca, a su vez, presenta las inserciones tendinosas de los músculos motores del globo ocular y numerosos orificios por donde pasan los vasos y nervios del globo.

La córnea es redondeada, enteramente transparente y constituye un segmento de esfera de un radio menor al de la esclera por ello protuye en la parte anterior del globo ocular. A su vez está constituida por dos caras. Se denomina limbo esclerocorneal a la zona, por medio de la cual la córnea, la esclera y la membrana mucosovascular se unen a la periferia de la córnea.

La úvea es la túnica vascular que se diferencia en tres segmentos que, de posterior a anterior, son la coroides, el cuerpo ciliar y el iris.

La coroides es una membrana esencialmente vascular situada entre la esclera y la retina, aproximadamente en los dos tercios posterior del globo ocular. Anteriormente

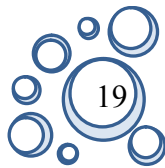


la coroides se continúa con el cuerpo ciliar. El límite anterior de la coroides está indicado por una línea circular y sinuosa denominada ora serrata.

El cuerpo ciliar es la parte de la capa vascular del globo ocular comprendida entre la ora serrata y el iris. El corte transversal del cuerpo ciliar es de forma triangular, con el vértice en la ora serrata y la base orientada hacia el eje del globo ocular.

El iris constituye la parte anterior. Se sitúa como un diafragma anterior al cristalino. Está perforado en su centro por un orificio denominado pupila.

La retina es la capa de tejido sensible a la luz que se encuentra en la parte más posterior del globo ocular. La retina convierte las imágenes en señales eléctricas y las envia por el nervio óptico al cerebro.

El cristalino está situado posteriormente al iris y anteriormente al cuerpo vítreo. Las dos caras de la lente anterior y posterior son convexas y se mantiene en su lugar mediante un sistema de fibras el cual se denomina zónula de Zinn. El humor acuoso es un líquido incoloro que llena el espacio entre la córnea y el cristalino.

El cuerpo vítreo es un gel transparente que rellena toda la parte de la cavidad ocular posterior a la lente. Está envuelto por una membrana llamada hialoides la cual se adhiere débilmente a la superficie interna de la retina.

\subsection{Los párpados}

Entre los anejos oculares se encuentran los párpados son pliegues musculomembranosos móviles que se extienden sobre la parte anterior del ojo cuando éste se cierra. De esta manera se protege al ojo constituyendo la primera barrera mecánica de protección del globo ocular. Posee además otras funciones como evitar la desecación de la córnea y conjuntiva, proteger la superficie ocular del traumatismo, renovar la película lagrimal y eliminan las sustancias tóxicas y de desecho mediante el parpadeo y ayudar a la pupila a delimitar la cantidad de luz que penetra en el ojo. 
Los párpados son convexos hacia delante, en correspondencia con la curvatura del globo ocular, siendo el párpado superior, más grande que el inferior. A su vez, cada párpado presenta dos caras, una anterior y una posterior; dos extremos, uno medial y otro lateral, y dos bordes, uno adherente y otro libre.

La cara anterior presenta dos partes una es convexa y resistente, en relación con el globo ocular que es la porción ocular o tarsal de los párpados; la otra comprendida entre la porción tarsal y el borde orbitario, es la porción orbitaria que es de consistencia blanda y corresponde en profundidad a la grasa de la cavidad orbitaria.

Las porciones ocular y orbitaria de cada párpado están separadas por el surco palpebral.

Su cara posterior está constituida principalmente por conjuntiva, los extremos de los párpados se unen y forman las comisuras. El borde adherente corresponde al borde orbitario. El borde libre mide $3 \mathrm{~cm}$ de longitud y $2 \mathrm{~mm}$ de espesor. La hendidura palpebral es el área que queda entre los párpados cuando este está abierto.

Aunque existen numerosas variaciones en relación a la posición de los márgenes palpebrales, generalmente el párpado superior solo cubre la parte superior del limbo cuando los ojos están abiertos mirando al frente. La posición del párpado inferior es más variable, generalmente a un milímetro del limbo inferior.

Los dos párpados presentan las mismas características generales y se componen de una serie de planos superpuestos que son, de anterior a posterior (Fig. 1):

La piel palpebral es una capa muy delgada y posee finas vellosidades con sus correspondientes glándulas sebáceas. También tiene numerosas glándulas sudoríparas. La piel de los párpados es muy pigmentada, dado que se encuentran muchos melanocitos en la epidermis. 
La capa de tejido celular subdérmica es muy laxa y rara vez contiene tejido adiposo.

La porción palpebral del músculo orbicular se encarga del cierre palpebral, y se inserta como una delgada lámina de fibras musculares concéntricas entre la piel y el tarso disponiéndose alrededor de la hendidura palpebral. Este músculo esta inervado por el nervio facial y con su contracción se produce el parpadeo, que es involuntario, a pesar de las características estriadas de la musculatura y de la inervación somática eferente.

La segunda capa de tejido celular laxo está comprendida entre el músculo orbicular del ojo y el plano fibroelástico, es delgada y presenta las mismas características que la capa de tejido celular subdérmica. Está recorrida por las ramificaciones principales de las arterias palpebrales.

El tarso y el septum orbitario (plano fibroelástico) son el esqueleto de tejido conectivo del párpado, pues se componen de tejido conectivo de colágeno. Cada tarso posee la forma del párpado correspondiente de manera que el tarso superior es de forma semilunar y el inferior rectangular. Los tarsos se moldean sobre la curvatura del globo ocular. Los extremos correspondientes de los tarsos superior e inferior se unen mediante fascículos fibrosos tarsianos muy cortos. De esta unión resulta la formación de dos cintillas fibrosas, una medial y otra lateral que reciben el nombre de ligamentos palpebrales. Los tarsos contienen en su espesor las glándulas de secreción sebácea entre las que destacan las glándulas de Meibomio.

Las glándulas de Meibomio son glándulas sebáceas grandes modificadas y no relacionadas con folículos pilosos. Se observan alrededor de 30 en cada párpado, alguna más en el superior que en el inferior. Cada glándula está constituida por 10-15 lóbulos o acinos unidos a un largo tubo recto de recorrido vertical a través de toda la altura del 
tarso que desemboca en el borde libre del párpado, justo por delante del borde posterior. Las glándulas se disponen en una hilera en cada tarso hasta ocupar casi todo su espesor.

Son glándulas de naturaleza holocrinas, es decir, su secreción se produce por descomposición de toda la célula. Las células descompuestas se mueven a través del conducto hacia la abertura. La presión ejercida por el parpadeo libera la secreción en la película lagrimal y en ese momento la secreción (gotas de lípidos y restos celulares) forma la capa más externa de la película lagrimal. Esta secreción propia de las glándulas de Meibomio, se ha llamado meibum para distinguirla del sebo secretado por las glándulas sebáceas de los folículos de la piel y el pelo. El meibum es más viscoso que el sebo y es menos polar.

Histológicamente, las glándulas de Zeiss son similares a las de Meibomio. Sin embargo; están compuestas de 1 ó 2 acinos y están asociadas a un folículo de la pestaña, liberando sebo en el folículo, lo que impide que las pestañas se sequen y sean quebradizas.

La secreción grasa de ambas glándulas, Meibomio y Zeiss, lubrica los bordes de los párpados e impide que se adhieran y que el líquido lagrimal rebase los límites palpebrales protegiendo la piel de la maceración.

El músculo elevador del párpado superior está muy relacionado con el tarso superior, comienza en la parte posterior de la órbita, transcurre hacia delante y termina en un tendón con forma de abanico, con una hoja superficial y una profunda. El músculo elevador del párpado superior es inervado por el nervio motor ocular común.

El músculo de Müller es una capa muscular lisa constituida en cada párpado por una lámina de fibras musculares lisas en dirección vertical, que se denominan músculos tarsales. El músculo tarsal superior se comunica con el músculo elevador del párpado superior, mientras que el músculo tarsal inferior se fija al tarso inferior, y éste se une al

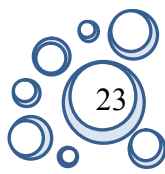


músculo oblicuo menor. Los dos músculos tarsales están inervados por el sistema simpático cervical.

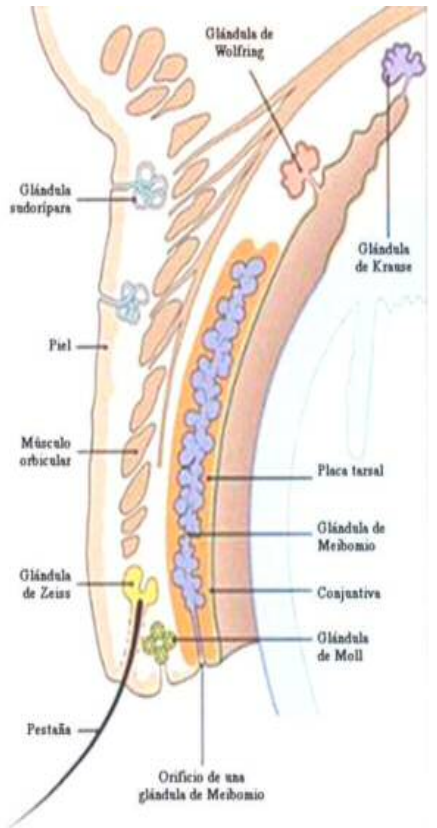

A

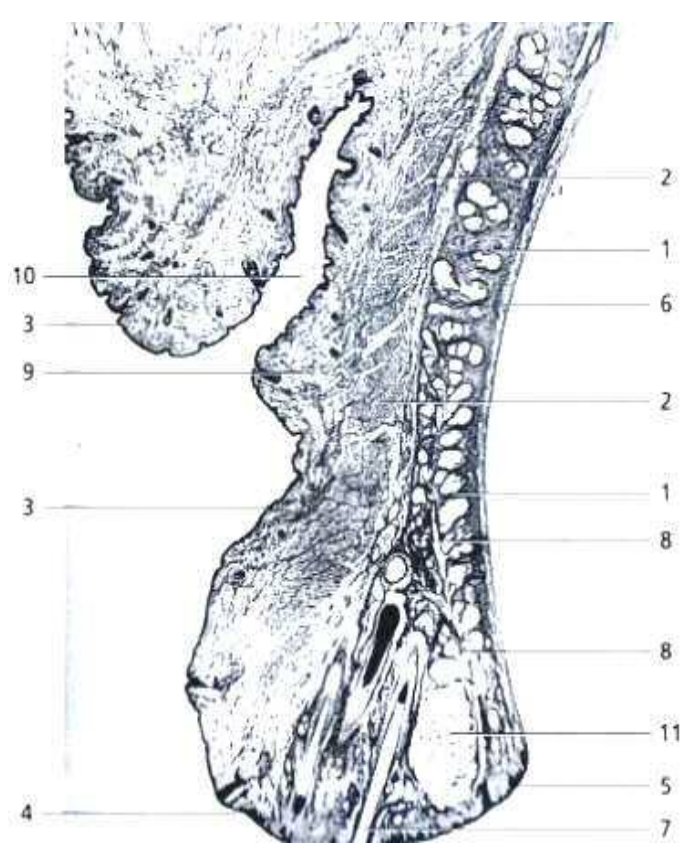

B

Fig. 1. A. Esquema del párpado formado por piel, músculo orbicular, tarso y conjuntiva. Contiene varios tipos de glándulas. B. Párpado. Tinción con hematosilina-eosina. Cada párpado está compuesto por una lámina densa fibroelástica, el tarso (1), cubierta externamente por una piel fina y muy plegada (3) y en su parte interna por tejido subcutáneo laxo (9) y conjuntiva tarsal (6). Las fibras musculares del músculo orbicular (2) y del elevador del párpado aparecen sobre el tarso. Dentro del tarso se encuentran las glándulas de Meibomio (7). Asociadas a las pestañas (6) están las glándulas de Zeiss y de Moll.

Los párpados están recubiertos posteriormente por la conjuntiva que es una mucosa delgada, lisa y transparente, que recubre la superficie posterior de los párpados bajo la forma de la conjuntiva tarsal, y la cara anterior del globo ocular, desde el surco escleral hasta la inserción de los músculos rectos, bajo la forma de la conjuntiva bulbar. Los pliegues entre las conjuntivas tarsal y bulbar se denominan fórnix o fondo de saco conjuntival. A nivel de los bordes palpebrales, la conjuntiva se continúa con la piel a lo largo del borde posterior del orificio de las glándulas tarsales.

Las pestañas parten del borde libre de los párpados en 2-3 hileras irregulares, se tratan de pelos terminales que son más largos y numerosos en el párpado superior. Los

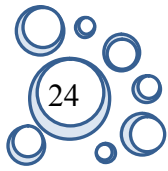


folículos pilosos de las pestañas se extienden unos milímetros hacia arriba y abajo en el tejido conectivo denso que se continúa en el tarso cerca del borde del párpado. Los folículos pilosos carecen de músculo erector del pelo. Las glándulas de Zeiss son glándulas sebáceas que se localizan cerca de los bordes de los párpados y son bastante grandes (aunque más pequeñas que las glándulas de Meibomio). Las glándulas de Moll son glándulas sudoríparas apocrinas modificadas que se encuentran entre los folículos pilosos de las pestañas. Estas se abren sobre los bordes libres de los párpados. Estudios histoquímicos recientes han identificado péptidos antimicrobianos y proteínas en las secreciones de la glándula lo que sugiere el papel de la inmunidad para proteger el eje de las pestañas y de la superficie ocular.

La vascularización e inervación palpebral está compuesta fundamentalmente por las arterias palpebral superior e inferior. Nacidas de la arteria oftálmica e inferiores a la tróclea del músculo oblicuo superior, las arterias palpebrales se dirigen hacia el borde libre del párpado correspondiente. Seguidamente discurren de medial a lateral cerca del borde libre del párpado. Así alcanzan el ángulo lateral, dónde terminan anastomosándose entre sí. Los párpados reciben además algunos ramos de las arterias supraorbitarias, supratroclear, lagrimal y angular.

Las venas situadas en la capa suborbicular desembocan lateralmente en las venas de la región temporal y medialmente en la vena angular. Las otras son subconjuntivales y tributarias de las venas oftálmicas.

Los vasos linfáticos nacen de dos redes, una subcutánea y otra subconjuntival. Los vasos mediales van a los nódulos linfáticos submandibulares y los linfáticos laterales se dirigen a los nódulos linfáticos parotídeos. 
El nervio facial inerva el músculo orbicular del ojo. Los nervios sensitivos proceden del nervio infratroclear medialmente, el nervio supratroclear superiormente, el nervio lagrimal lateralmente y el nervio infraorbitario inferiormente.

\subsection{La conjuntiva}

Se trata de una membrana mucosa delgada y traslucida que se extiende desde el limbo sobre la esclera anterior hasta la línea de los párpados. Desde el punto de vista descriptivo, en la conjuntiva se describen tres porciones: la conjuntiva palpebral o tarsal, la conjuntiva del fórnix y la conjuntiva bulbar.

La conjuntiva palpebral o tarsal se inicia en el borde libre de cada párpado, donde tiene continuidad con la piel. Está compuesta por dos capas, una de epitelio estratificado y otra de tejido conectivo estromal denominada submucosa.

La capa epitelial de la conjuntiva es una continuación del epitelio de la piel en la unión musculocutánea de los bordes del párpado. Se sustituyen las células escamosas por células cúbicas y columnares formando un epitelio estratificado ${ }^{3,4}$. En la unión mucocutánea, la capa epitelial es de aproximadamente cinco células de espesor y puede dar lugar a células madre para repoblar el epitelio conjuntival palpebral. En el párpado superior, el epitelio conjuntival es de 2 a 3 células de espesor mientras que en el párpado inferior es de 3 a 4 células de espesor ${ }^{5}$. Este epitelio se continúa a través de los fondos de saco en la conjuntiva bulbar, donde cambia de estratificado a escamoso cerca del limbo convirtiéndose en el epitelio corneal. Las invaginaciones del epitelio conjuntival, a menudo situadas cerca del fondo de saco se denominan criptas de Henle. La superficie de las células conjuntivales superficiales, sus microvellosidades y micropliegues, están cubiertas por un glicocalix similar al de la superficie corneal $^{6,7}$. 
Las células caliciformes producen, almacenan y secretan la capa mucosa de la película lagrimal y se encuentran dispersas por todo el epitelio conjuntival, siendo más numerosas en la conjuntiva tarsal nasal inferior.

Los sistemas simpático y parasimpático se han asociado al funcionamiento de las células caliciformes y por lo tanto, podrían desempeñar un papel en su secreción ${ }^{8}$.

La submucosa o estroma de la conjuntiva palpebral es una capa muy delgada en la parte tarsal del párpado y se va volviendo cada vez más gruesa a nivel de la porción orbitaria. Se compone de un tejido conectivo laxo vascularizado que se puede subdividir en una capa exterior linfoide y una capa fibrosa de profundidad. Además de los componentes normales del tejido conjuntivo (fibrillas de colágeno, fibroblastos, sustancia fundamental, y fibras elásticas finas). La capa linfoide contiene macrófagos, mastocitos, leucocitos polimorfonucleares, eosinófilos, acumulaciones de linfocitos y ocasionales células de Langerhans ${ }^{9}$. Además contiene inmunoglobulina A ( $\left.\operatorname{Ig} \mathrm{A}\right)$, por lo que la conjuntiva es un tejido inmunológicamente activo ${ }^{10,11}$. Existe más tejido linfoide en la conjuntiva palpebral que en la bulbar ${ }^{12}$. La capa fibrosa profunda conecta a la conjuntiva estructuras subyacentes y contiene una red aleatoria de fibrillas de colágeno y fibroblastos, numerosos vasos sanguíneos, nervios y glándulas lagrimales accesorias. Esta capa fibrosa se funde y se continúa con el conectivo denso tejido de la placa tarsal.

Las células madre de la conjuntiva se encuentran dispersas en la capa basal de la conjuntiva siendo más numerosas en los fondos de saco.

La reflexión de la conjuntiva palpebral sobre el globo ocular se realiza a una distancia de la córnea que difiere según los meridianos que se consideren formando un fondo de saco irregularmente circular denominado fondo de saco conjuntival o fórnix.

Los fondos de saco se unen débilmente a las extensiones de la fascia del músculo elevador proporcionando la coordinación del movimiento conjuntival con el

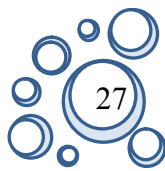


movimiento del globo y de los párpados. Además, los fórnices colaboran logrando el movimiento del globo ocular sin generar tensiones en la conjuntiva. En la unión cutáneo-mucosa del borde palpebral el epitelio escamoso conjuntival no queratinizado se continúa con el epitelio escamoso queratinizado de la epidermis del párpado.

En la conjuntiva bulbar se distinguen dos porciones: una porción escleral y una corneal

El pliegue semilunar es un repliegue conjuntival, vertical, falciforme y aplanado de anterior a posterior, cuyo borde libre es cóncavo y situado en el canto medial. Su epitelio está compuesto por 8-10 capas de células de espesor y contiene células caliciformes y un estroma muy vascularizado, fibras musculares lisas y tejido adiposo. El pliegue semilunar corresponde al tercer párpado de algunos vertebrados (membrana nictitante de las aves).

La carúncula lagrimal, es una estructura medial al pliegue semilunar y constituye un segmento aislado de los párpados. Histológicamente la carúncula es similar a la conjuntiva, contiene epitelio no queratinizado y glándulas lagrimales accesorias, aunque también tiene elementos cutáneos como folículos pilosos, glándulas sebáceas y sudoríparas.

La vascularización conjuntival está compuesta por arterias que son ramas de las arcadas que se anastomosan a ambos lados de la placa tarsal. La irrigación de los fondos de saco procede de las arcadas periféricas. Estas se anastomosan con el plexo de las arterias conjuntivales anteriores formadas por ramas de las arterias ciliares anteriores. Las venas conjuntivales son más numerosas y paralelas a las arterias, estas drenan en las venas palpebrales y venas oftálmicas. Los vasos linfáticos se organizan en redes superficiales y profundas dentro de la submucosa. Los de la cara medial desembocan en 
el ganglio linfático submandibular y los de la cara lateral en el ganglio linfático de la parótida.

La inervación sensorial de la conjuntiva bulbar está mediada por los nervios ciliares largos. La de la conjuntiva palpebral superior procede de distintas ramas del nervio frontal y lagrimal del nervio oftálmico. La de la conjuntiva palpebral inferior del nervio lagrimal y la rama infraorbitaria del maxilar. Toda la información sensitiva es llevada por el nervio trigémino.

El aparato lagrimal constituye otro anejo del órgano de la visión y está formado por la glándula lagrimal, destinada a secretar las lágrimas, y por las vías lagrimales, que conducen a las cavidades nasales las lágrimas vertidas por los conductillos excretores de la glándula.

Las glándulas lagrimales constan de una glándula lagrimal principal y varias glándulas accesorias. La glándula lagrimal principal se localiza en la porción temporal superior de la órbita ubicándose en la fosa de la glándula lagrimal, justo por dentro del ángulo ocular lateral y por detrás del septum orbital. Es una glándula arracimada tubuloacinosa que consta de dos porciones: una mayor y superior denominada porción orbitaria, y una menor e inferior, la porción palpebral. Estas dos porciones están separadas por un plano fibrotendinoso constituido por el haz orbitario lateral del músculo elevador del párpado superior, la expansión del músculo recto superior y la aleta ligamentosa lateral de la vaina del globo ocular. A su vez presenta dos porciones:

- La porción orbitaria aplanada de superior a inferior y de forma oval. Su eje mayor se dirige en sentido oblicuo posterior, lateral e inferomedialmente.

- La porción palpebral que es una masa formada por 15-40 lóbulos, aplanada de superior a inferior y ubicada en el párpado superior a lo largo de la parte superolateral del fondo de saco conjuntival superior. 
La glándula tiene unos 10 conductos excretores provenientes de ambas porciones y todas desembocan en el fondo de saco conjuntival superior. Todos los conductos excretores atraviesan la porción palpebral de la glándula.

Desde el punto de vista histológico, la glándula lagrimal es una glándula tubular que sólo contiene células glandulares serosas en las terminales secretoras. Estas poseen una luz bastante grande, que suele contener producto de secreción, y células casi cilíndricas. En las porciones terminales y en los conductos excretores se ven abundantes células mioepiteliales insertadas entre las células epiteliales y la membrana basal. Las porciones terminales secretoras y los conductos excretores están rodeados por estroma de tejido conectivo laxo, que suele ser rica en linfocitos y en células plasmáticas productoras de $\operatorname{IgA}$ que liberan al líquido lagrimal. Los conductos excretores más pequeños contienen un epitelio cúbico bajo que pasa a cilíndrico en los conductos interlobulillares y luego a epitelio de dos capas.

Cada unidad acinar o unidad secretora, de la glándula lagrimal está compuesta por una capa interna de células cilíndricas secretoras dispuestas hacia una luz central, rodeadas por una capa basal de células mioepiteliales. Estas células mioepiteliales al contraerse facilitan la salida de las secreciones hacia el sistema de drenaje tubular.

Las glándulas lagrimales accesorias se hallan distribuidas en el tejido subconjuntival, a lo largo de los fórnices conjuntivales, estas reciben el nombre de glándulas de Krause, y las que se hallan distribuidas en los párpados se denominan glándulas de Wolfring- Ciaccio. El volumen total de todas las glándulas accesorias es de 0,1 ml. Se trata de un grupo de células secretoras con una forma de tronco piramidal dispuestas en un patrón de ovillo alrededor de una luz central ${ }^{13}$. Los acinos están a veces rodeados de una forma incompleta por una capa de células mioepiteliales. Su secreción contiene agentes antibacterianos, lisozima, lactoferrina e inmunoglobulinas. 
La vascularización de la glándula lagrimal se compone de la arteria lagrimal. La sangre venosa se vierte, por medio de la vena lagrimal, en la vena oftálmica superior. Los vasos linfáticos rodean el reborde de la órbita y se dirigen a los nódulos linfáticos parotídeos.

La inervación procede del nervio lagrimal, que es ramo del nervio oftálmico.

\section{- Inervación funcional de la glándula lagrimal.}

La glándula principal produce secreciones basal, refleja y emocional. Los neurotransmisores liberados en las terminaciones nerviosas autonómicas de las glándulas lagrimales pueden ser colinérgicos, adrenérgicos y peptidérgicos.

Las terminaciones colinérgicas están en las caras basal e intercelular de los lacrimocitos. Cuando se estimulan, producen simultáneamente secreción de los lacrimocitos, exprimido de los acinos por contracción de las células de Boll y vasodilatación de las arteriolas lacrimales.

Las terminaciones adrenérgicas se saben que existen en las glándulas lagrimales, pero se discute si se encuentran los lacrimocitos.

Las terminaciones peptidérgicas responden a determinados péptidos, de los cuales el más conocido es el VIP (vasoactive intestinal polypeptid), un potente estimulador de la secreción acuosa y proteica de la glándula lagrimal. Otros péptidos detectados en las glándulas lacrimales son la substancia P, el CGRP (calcitonina gene-related peptide) y la 5-hidroxitriptamina.

La vía parasimpática está constituida por el núcleo parasimpático preganglionar lacrimosecretor que está situado en la parte ventral del núcleo salival superior, en el tronco del encéfalo. De sus cuerpos neuronales salen unos axones de $10 \mathrm{~cm}$ de longitud que se separan a nivel del ganglio geniculado en el interior del peñasco, siguen por el

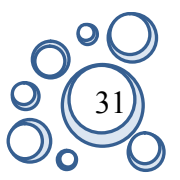


nervio petroso superficial mayor, continuan por el nervio vidiano y finalmente llegan al ganglio esfenopalatino. Allí, sinaptan con los cuerpos neuronales de la segunda neurona. De ellas salen los axones postganglionares, que saltan a la segunda rama del trigémino y penetran en la órbita por la rama orbitocigomática, continúan por su ramo anastomótico al nervio lagrimal (rama de la primera rama del trigémino) y directamente o a través del nervio lagrimal alcanzan la glándula lagrimal principal.

La vía simpática parte del núcleo simpático preganglionar está situado en la columna gris del asta intermedio lateral de la médula cervicodorsal, escalonado entre los niveles de la Dorsa1 1 (D1) y Dorsal 4 (D4). Sus axones siguen por los ramos comunicantes blancos D1, D2 y D3, ascienden por la cadena simpática paravertebral y alcanzan el ganglio cervical superior, donde sinaptan con los cuerpos neuronales de la segunda neurona. De ellos salen los axones postganglionares que saltan al plexo carotídeo. Desde allí alcanzan la glándula lagrimal y los vasos de la cuenca lagrimal por la arteria oftálmica y sus ramas, por anastomosis con el ganglio de Gasser y la primera rama del trigémino, y por anastomosis con el nervio Vidiano y vía parasimpática.

Todavía no existe acuerdo sobre las contribuciones relativas de las glándulas principales y accesorias. En la visión tradicional, las glándulas accesorias proporcionan la secreción basal y la principal está relacionada con la secreción refleja.

\subsection{Vía lagrimal}

Las lágrimas secretadas por las glándulas lagrimales se dirigen, gracias al movimiento de los párpados, hacia el lago lagrimal situado en el ángulo medial del ojo. Del lago lagrimal son transportadas a las cavidades nasales por las vías lagrimales.

Las vías lagrimales comienzan en el borde libre de los párpados en los puntos lagrimales. De los puntos lagrimales a las cavidades nasales, las vías lagrimales están 
constituidas por los canalículos lagrimales, el saco lagrimal y el conducto nasolagrimal (Fig. 2).

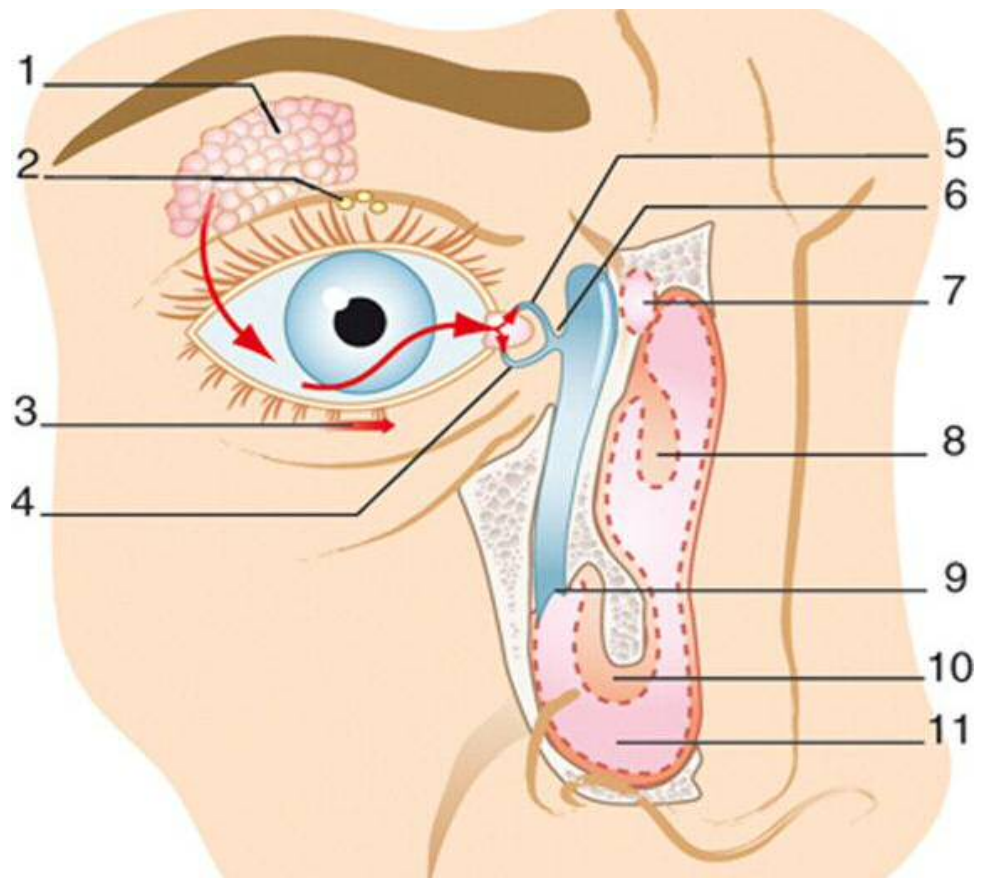

Fig. 2. Localización de las vías lagrimales. 1. Gándula lagrimal pricipal. 2. Glándulas lagrimales accesorias. 3. Dirección del flujo lagrimal. 4. Canaliculo lagrimal inferior. 5 Canalículo lagrimal superior.6. Canalículo común. 7. Concha nasal superior. 8. Concha nasal media. 9. Válvula de Hassner (conducto lacrimonasal). 10. Concha nasal inferior. 11. Meato nasal inferior.

Los puntos lagrimales son dos, uno para cada párpado. Gracias a su disposición, cuando se ocluyen los párpados, los puntos se yuxtaponen. Los canalículos lagrimales pasan por el espesor del borde libre de los párpados. Cada uno de ellos adopta primero una dirección vertical, y después se continúan horizontalmente en sentido medial.

El saco lagrimal es un conducto cilíndrico, ligeramente aplanado transversalmente y cerrado en su parte superior, donde termina en un fondo de saco que se abre inferiormente en el conducto nasolagrimal con el que se continúa. Su dirección no es del todo vertical, si no ligeramente oblicuo inferior, lateral y posteriormente.

El conducto nasolagrimal se extiende desde el saco lagrimal hasta el meato nasal inferior. Está contenido en un conducto óseo. Su superficie interna es irregular y 
presenta numerosos pliegues mucosos. De estos repliegues unos son más contantes que otros y se denominan válvulas.

La vascularización de las vías lagrimales está compuesta por las arterias de las vías lagrimales que proceden de las arterias palpebrales superior e inferior y de la arteria dorsal de la nariz, ramas de la arteria oftálmica. Las venas de las vías lagrimales forman, alrededor del saco lagrimal y del conducto nasolagrimal, un plexo venoso especialmente abundante alrededor del conducto. De estos plexos parten venas que se dirigen superiormente hacia las ramas de origen de las venas oftálmicas y a la vena angular e inferiormente hacia los plexos venosos del cornete nasal inferior. Los vasos linfáticos desembocan en los nódulos linfáticos submandibulares. Inferiormente, los vasos linfáticos comunican con la red linfática de las cavidades nasales y son, al igual que esta, tributarios de los nódulos linfáticos cervicales laterales profundos y de los nódulos linfáticos retrofaríngeos. La inervación de las vías lagrimales procede fundamentalmente del nervio infratroclear.

\subsection{La película lagrimal}

La película lagrimal cubre la superficie anterior del globo ocular, tiene numerosas funciones:

- Mantiene la superficie húmeda y sirve como lubricante entre los globos y los párpados.

- Atrapa residuos y ayuda a eliminar la capa de células epiteliales de desecho.

- Constituye la fuente primaria de oxígeno para la córnea.

- Proporciona una superficie lisa refractiva para dar una función óptica óptima ${ }^{14}$.

- Contiene agentes antimicrobianos que protegen de una posible infección ${ }^{15}$ (lisozima, lactoferrina, inmunoglobulinas...). 
- Ayuda a mantener la hidratación de la córnea por cambios de tonicidad que se producen con la evaporación ${ }^{16}$.

La película lagrimal se compone de tres capas (Fig. 3):

- La capa más externa es la capa lipídica que está formada por ésteres, colesterol y ácidos grasos libres. Está producida principalmente por las glándulas de Meibomio. Proporciona lubricación y retrasa la evaporación.

- La capa media es la acuosa que contiene sales inorgánicas, glucosa, urea, enzimas, proteínas, glicoproteínas y la mayoría de las sustancias antibacterianas. Es secretada por las glándulas accesorias y principal.

- La capa más interna es la mucosa y facilita la adhesión de la capa acuosa de las lágrimas a la superficie ocular ${ }^{17,18}$. Está compuesta de un glicocalix secretado por el epitelio de superficie y mucina producido por las células caliciformes.

Según algunos autores, la película lagrimal tiene de 7 a $10 \mu \mathrm{m}$ de espesor siendo la capa acuosa la más importante, representando un $90 \%$ del espesor ${ }^{19}$. Otros autores han sugerido que la capa lagrimal tiene un espesor de 35 a $45 \mu \mathrm{m}$ siendo la capa mucosa la más espesa ${ }^{20-22}$. Las porciones mucosa y acuosa no son estáticas y no permanecen como capas separas y diferenciadas pero pueden formar un tipo de gradiente que obstaculiza llevar a cabo estas medidas precisas ${ }^{23}$.

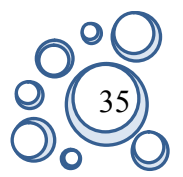


--ー-ー-ー: Capa lipídica

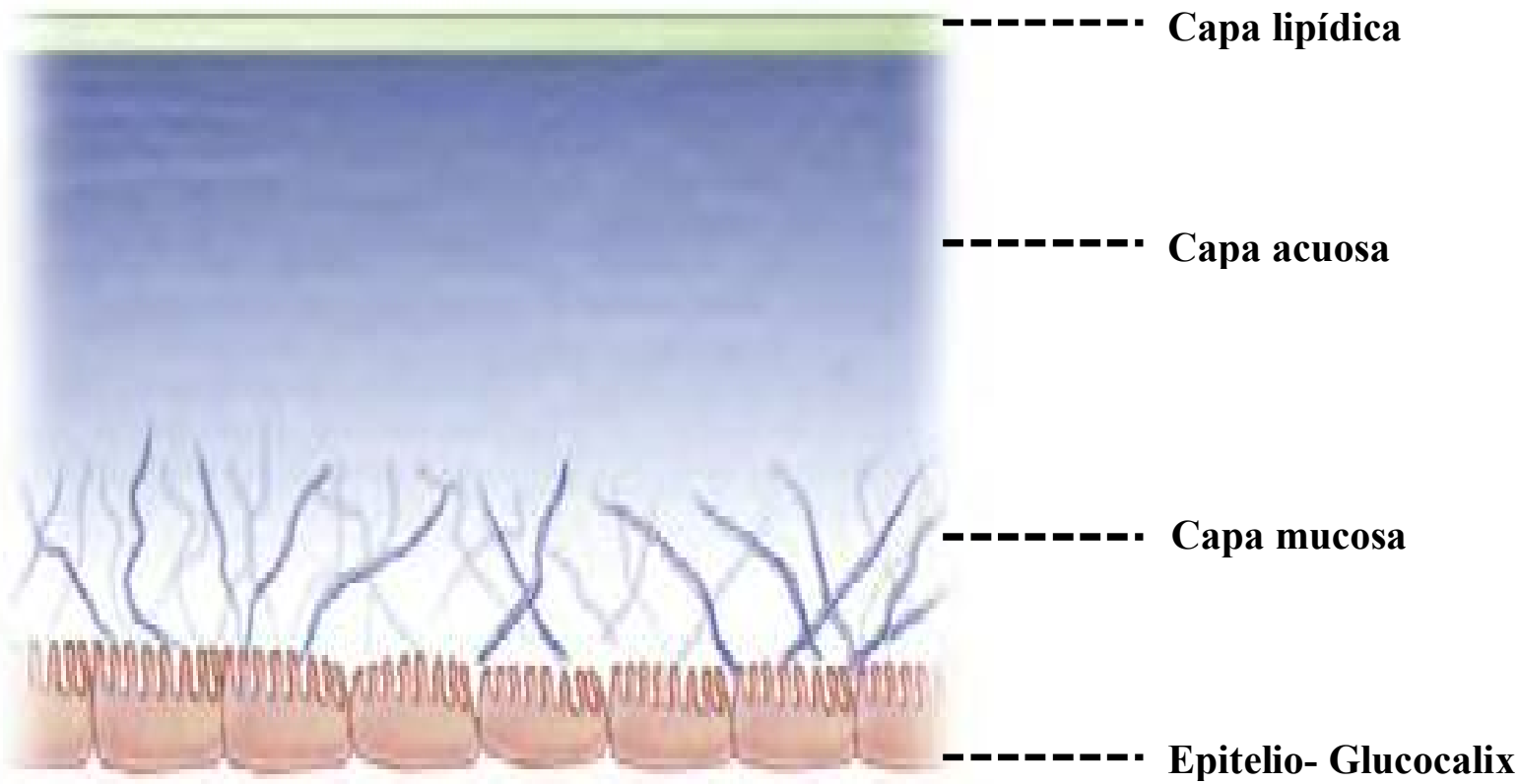

Fig. 3. Esquema representativo de la película lagrimal.

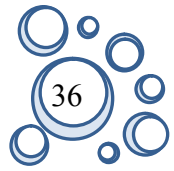




\section{ENFERMEDAD INJERTO CONTRA RECEPTOR (EICR)}

El trasplante alogénico de progenitores hematopoyéticos (alo-TPH) representa un tratamiento potencialmente curativo en casos de enfermedades hematológicas benignas y malignas, lo cual justifica el número creciente de trasplantes realizados a nivel mundial desde su desarrollo hace más de 50 años. Se trata, por tanto, de una estrategia terapéutica sobre la que existe una amplia experiencia. Sin embargo, no está exenta de complicaciones, la más relevante de las cuales es la enfermedad injerto contra receptor (EICR) la cual constituye una causa importante de morbimortalidad entre los pacientes sometidos a esta terapia.

La incidencia de la EICR puede alcanzar hasta un $80 \%$ en la serie de pacientes sometidos a trasplante alogénico de progenitores hematopoyéticos de donante no emparentado. Sin embargo, el desarrollo de EICR se asocia en ocasiones con el reconocimiento de las células tumorales por parte de los linfocitos $\mathrm{T}$ del donante, y este efecto inmunoterápico es lo que se conoce como el efecto injerto contra leucemia $(\text { EICL })^{24,25}$ y es la base de las propiedades curativas del alo-TPH.

La incidencia de EICR varía dependiendo de diversos factores como son la fuente del tejido donante, edad, enfermedad subyacente, intensidad del proceso de acondicionamiento, grado de histocompatibilidad y sexo de donante y receptor ${ }^{26-30}$. Los órganos diana implicados en la EICR dependen del subtipo de EICR, como vamos a ver a continuación. En la EICR aguda se afectan fundamentalmente la piel, el tubo digestivo y el hígado. En la EICR crónica, además de la piel y mucosas, es frecuente la afectación ocular, pulmonar y en menor medida otros órganos ${ }^{31,32}$. 


\subsection{Clasificación de la EICR}

Existen dos formas clásicas de EICR, aguda y crónica. En el pasado la diferencia entre ambas estaba establecida por el momento de su desarrollo. Así, la EICR se clasificaba en aguda (si se desarrollaba en los primeros 100 días postransplante) y crónica (si aparecía tras este periodo). Esta distinción arbitraria basada en el tiempo de inicio no refleja las diferencias fisiopatológicas y clínicas entre la forma aguda y la crónica. Según un consenso reciente, van a ser las manifestaciones clínicas y no el tiempo de aparición de los síntomas las que van a determina si un caso de EICR se clasifica como agudo o como crónico (Tabla 1).

La EICR aguda en estos momentos incluye:

1) EICR clásica con afectación cutánea (erupción maculopapular), gastrointestinal (náuseas, vómitos, anorexia, íleo y/o diarrea), y/o hepática (colestasis) que ocurre dentro de los primeros 100 días postrasplante sin la aparición de signos distintivos de la EICR crónica.

2) EICR aguda persistente recurrente o de inicio tardío, la cual presenta las características de la EICR descrita en el apartado anterior sin diagnóstico ni signos distintivos de la EICR crónica y que se producen después de los 100 días postrasplante.

La EICR crónica incluye:

1) EICR crónica clásica sin características de EICR aguda, que puede ocurrir en cualquier momento postrasplante. Sus características principales se incluyen en el apartado 2.3 (Tabla 2).

2) El síndrome de solapamiento en la cual, la forma aguda y crónica se producen de forma concomitante. 
Es necesario señalar que la recurrencia o nueva aparición de alteraciones características cutáneas, gastrointestinales y hepáticas en ausencia de hallazgos histológicos o clínicos de EICR crónica deben clasificarse como EICR aguda, independientemente del tiempo transcurrido tras el trasplante ${ }^{33}$.

Tabla 1. Diagnóstico diferencial entre EICR aguda y EICR crónica

\begin{tabular}{|c|c|c|c|}
\hline Tipo & $\begin{array}{l}\text { Tiempo de aparición } \\
\text { tras TPH o ILD }\end{array}$ & $\begin{array}{c}\text { Presencia de } \\
\text { signos/síntomas de } \\
\text { EICR aguda }\end{array}$ & $\begin{array}{c}\text { Presencia de signos/ } \\
\text { síntomas de EICR } \\
\text { crónica }\end{array}$ \\
\hline $\begin{array}{l}\text { EICR aguda } \\
\text { - Clásica } \\
\text { - } \quad \text { Persistente, } \\
\\
\text { recurrente o de } \\
\text { inicio tardío }\end{array}$ & $\begin{array}{l}\leq 100 \text { días } \\
>100 \text { días }\end{array}$ & $\begin{array}{l}\text { Sí } \\
\text { Sí }\end{array}$ & $\begin{array}{l}\text { No } \\
\text { No }\end{array}$ \\
\hline $\begin{array}{ll}\text { EICR crónica } & \\
- & \text { Clásica } \\
- & \text { Síndrome } \\
\text { solapamiento } & \text { de }\end{array}$ & Sin límite de tiempo & $\begin{array}{l}\text { No } \\
\text { Sí }\end{array}$ & $\begin{array}{l}\text { Sí } \\
\text { Sí }\end{array}$ \\
\hline
\end{tabular}

Para establecer el diagnóstico de EICR crónica, el grupo de trabajo NIH recomienda identificar al menos un signo o síntoma diagnóstico de la EICR crónica o la presencia de al menos un signo o síntoma característico (ver Tabla 2, apartado 2.3), siempre que se confirme el diagnostico mediante una biopsia o una prueba diagnóstica complementaria (test de laboratorio, prueba radiológica) en el mismo o en otro órgano ${ }^{33}$.

\subsection{Fisiopatología de la EICR}

La patogénesis de la EICR es multifactorial. Se trata de una enfermedad inmunomediada producto de complejas interacciones que se dan entre la respuesta inmune innata e inmune adaptativa del donante y del receptor. 


\subsubsection{EICR aguda}

La EICR aguda refleja una respuesta inflamatoria mediada por los linfocitos del donante en un microambiente alogénico. El desarrollo de la EICR aguda se puede dividir en tres fases (Fig. 4):

- Primera fase. Activación de células presentadoras de antígeno (CPA). Constituye la primera fase en el desarrollo de EICR aguda y se produce bien por la enfermedad subyacente y/o bien por el régimen de acondicionamiento. Los regimenes de acondicionamiento de baja intensidad activan con menor intensidad a las CPA. La activación de estas células conducen a un daño tisular del huésped mediante la liberación de citocinas proinflamatorias (como por ejemplo el factor de necrosis tumoral TNF $\alpha$ ), células degradadas y sus núcleos así como un aumento en la expresión de moléculas de adhesión (ICAM-1), antígenos del complejo mayor de histocompatibilidad (MHC) y moléculas coestimuladoras (Fig. 4) ${ }^{34-37}$.

- Segunda fase. Activación, proliferación, diferenciación y migración de las células $T$ donantes. Las interacciones entre las CPAs del receptor y los linfocitos $\mathrm{T}$ del donante conducen a la proliferación y diferenciación de las células $\mathrm{T}$ activadas, a su vez, esta proliferación se ve aumentada por las moléculas expresadas en la fase anterior ${ }^{38}$. Esta activación celular conduce a una cascada bioquímica compleja en la que se produce la transcripción de numerosas proteínas, incluyendo citocinas y sus receptores. Recientemente se ha reconocido la importancia de la vía reguladora constituida por el $\mathrm{CD} 4{ }^{+} \mathrm{CD} 25^{+} \mathrm{FoxP}^{+}$y células $\mathrm{T}$ reguladoras, así como la Interleucina 2 (IL-2) y el Interferon (IFN) y, el cual juega un doble papel en la EICR aguda generando un aumento de la expresión de receptores de citocinas, proteínas MHC y la 
adhesión molecular, facilitando de este modo la presentación de antígenos así como la sensibilidad de los monocitos y macrófagos a estímulos que aceleran las vías intracelulares de respuesta ${ }^{39}$. Las citocinas antiinflamatorias IL-10 y TGF- $\beta$ (secretada por los linfocitos T reguladores) pueden inhibir las CPAs, además de proporcionar la inhibición contacto-dependiente generada por los linfocitos $\mathrm{T}$ reguladores ${ }^{40}$. La IL-10 colabora en la regulación de la EICR aguda a través de su papel de supresión de la respuesta inmune según sugieren los hallazgos $\operatorname{clínicos}^{41}$. Aunque el TGF- $\beta$ reduce la EICR aguda, se ha observado que sus niveles se incrementan en la EICR crónica (Fig. 4).

- Tercera fase. Destrucción del tejido diana. La fase efectora comprende una compleja cascada que implica la liberación de mediadores inflamatorios los cuales promueven la destrucción de un tejido diana. Entre estos mediadores celulares se hallan los linfocitos T citotóxicos y las células NK y mediadores solubles tales como el IFN- y, IL-1, TNF- $\alpha$ y el óxido nítrico (Fig. 4$)^{42 .}$

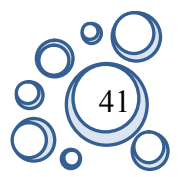




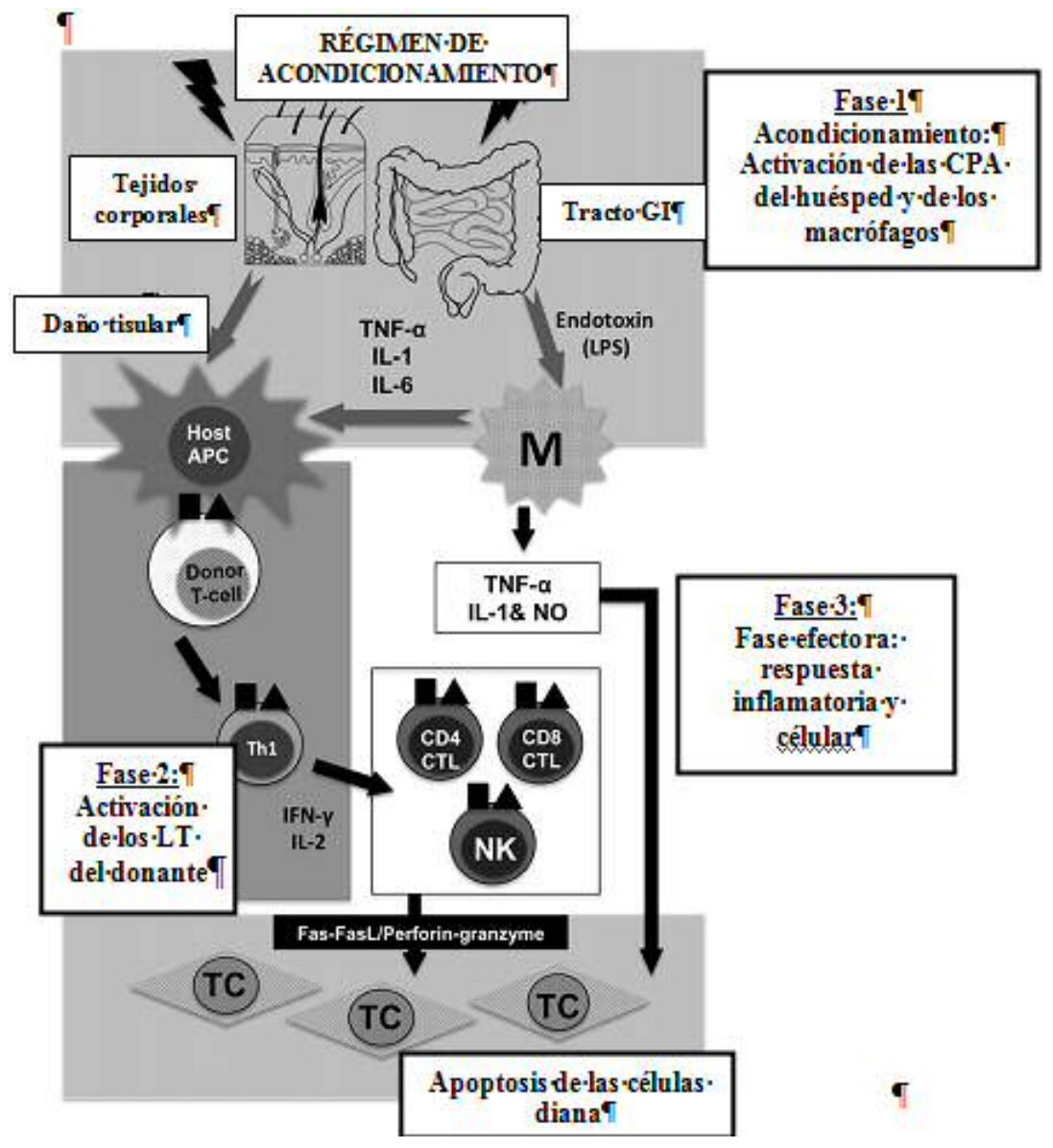

Fig. 4. Fisiopatología de la EICR aguda. APC: Células Presentadoras de Antígenos. LPS: Lipopolisacáridos.NK: Natural Killer. CTL: LT citotóxicos. NO: Oxido nítrico. TC: células diana. Adaptado de Shikari Hy cols. Survey of Ophthalmology. 58(3):233-250 .2013.

\subsubsection{EICR Crónica}

La fisiopatología de la EICR crónica es más compleja y menos conocida. Se ha postulado la posibilidad de que se desarrolle una reconstitución aberrante del sistema inmune conduciendo a una pérdida de la capacidad del mismo para llevar a cabo una regulación normal. Se ha observado que en los pacientes con EICR crónica existe una disminución de linfocitos $\mathrm{T}$ reguladores en volumen y en función ${ }^{43}$. Existe también disfunción tímica y alteración de las células B, junto a presencia de auto-anticuerpos ${ }^{44}$. 


\subsection{Manifestaciones clínicas de la EICR}

Las manifestaciones clínicas iniciales de la EICR aguda son secundarias al daño selectivo a los tejidos la piel, tracto gastrointestinal e hígado ${ }^{45}$.

- Piel. Es el órgano más comúnmente afectado y la EICR aguda se manifiesta por prurito o sensación de dolor cutáneo y erupción maculopapular en las formas hiperagudas se forman bullas con aparición de necrólisis epidérmica que se manifiesta por ampollas y se compromete gravemente el estado general ${ }^{46}$.

- Afectación gastrointestinal. La afección gastrointestinal consiste habitualmente en diarrea secretora muy voluminosa, asociada a dolor abdominal intenso en las formas graves ${ }^{47}$. La hemorragia digestiva resultante de la ulceración de la mucosa se asocia con un mal pronóstico ${ }^{48}$. Las formas leves pueden cursar únicamente con clínica gastrointestinal alta (náuseas, vómitos, sensación de plenitud) con o sin diarrea leve.

- Hígado. Se manifiesta fundamentalmente por ictericia. La alteración de la función hepática es común durante el período post-trasplante debido a la enfermedad veno-oclusiva, la toxicidad del acondicionamiento y a infecciones virales.

La EICR crónica puede afectar prácticamente a cualquier órgano, recordando a diversas enfermedades autoinmunes (Tabla 2). Los órganos evaluados son piel, boca, ojos, tracto gastrointestinal, hígado, pulmones, articulaciones, fascias y tracto genital femenino $^{33}$. 
Tabla 2. Signos y síntomas de EICR crónica por órganos y tejidos

\begin{tabular}{|c|c|c|c|c|}
\hline Órgano o tejido & Diagnóstico & Características & Otras manifestaciones & Comunes \\
\hline Piel & $\begin{array}{l}\text {-Poiquilodermia } \\
\text {-Liquen plano } \\
\text {-Cambios } \\
\text { escleróticos } \\
\text {-Morfea } \\
\text {-Liquen escleroso }\end{array}$ & -Despigmentación & $\begin{array}{l}\text {-Alteraciones en la } \\
\text { sudoración } \\
\text {-Ictidosis } \\
\text {-Hipopigmentación/ } \\
\text { Hiperpigmentación }\end{array}$ & $\begin{array}{l}\text {-Eritema } \\
\text {-Rash } \\
\text { maculopapular } \\
\text {-Prurito }\end{array}$ \\
\hline Uñas & & $\begin{array}{l}\text {-Distrofia } \\
\text {-Uñas quebradizas, } \\
\text { estrías } \\
\text {-Onicolisis } \\
\text {-Pterigium ungueal } \\
\text {-Pérdida ungueal }\end{array}$ & & \\
\hline $\begin{array}{l}\text { Cuero } \\
\text { cabelludo y } \\
\text { vello corporal }\end{array}$ & & $\begin{array}{l}\text {-Alopecia } \\
\text {-Lesiones } \\
\text { papuloescamosas }\end{array}$ & $\begin{array}{l}\text {-Pelo fino, desigual, } \\
\text { opaco } \\
\text {-Canas precoces }\end{array}$ & \\
\hline Boca & $\begin{array}{l}\text {-Liquen plano } \\
\text {-Hiperqueratosis } \\
\text {-Esclerosis } \\
\text { (dificultad } \\
\text { apertura boca) }\end{array}$ & $\begin{array}{l}\text {-Xerostomía } \\
\text {-Mucocele } \\
\text {-Atrofia mucosa }{ }^{\mathrm{b}} \\
\text {-Pseudomembranas } \\
\text {-Úlceras }\end{array}$ & & $\begin{array}{l}\text {-Gingivitis } \\
\text {-Mucositis } \\
\text {-Eritema } \\
\text {-Dolor }\end{array}$ \\
\hline Ojos & & $\begin{array}{l}\text {-Ojo seco: dolor, } \\
\text { sensación de cuerpo } \\
\text { extraño }^{c} \\
\text {-Conjuntivitis } \\
\text { cicatricial } \\
\text {-Queratoconjuntivitis } \\
\text { seca }^{c} \\
\text {-Queratopatía } \\
\text { punctata. } \\
\text {-Queratitis } \\
\text { filamentosa }\end{array}$ & $\begin{array}{l}\text {-Fotofobia } \\
\text {-Hiperpigmentación } \\
\text { periorbitaria } \\
\text {-Blefaritis }\end{array}$ & \\
\hline
\end{tabular}<smiles></smiles> 


\begin{tabular}{|c|c|c|c|c|}
\hline Genitales & $\begin{array}{l}\text {-Liquen plano } \\
\text {-Estenosis vaginal }\end{array}$ & & & \\
\hline $\begin{array}{l}\text { Tracto } \\
\text { gastrointestinal }\end{array}$ & $\begin{array}{l}\text {-Liquen plano } \\
\text {-Estenosis alta o } \\
1 / 3 \text { medio esófago }\end{array}$ & & $\begin{array}{l}\text {-Insuficiencia } \\
\text { pancreática exocrina }\end{array}$ & $\begin{array}{l}\text {-Anorexia } \\
\text {-Náuseas- } \\
\text { vómitos } \\
\text {-Diarrea } \\
\text {-Pérdida de } \\
\text { peso } \\
\text {-Retraso en el } \\
\text { crecimiento } \\
\text { (niños) }\end{array}$ \\
\hline Hígado & & & & $\begin{array}{l}\text {-Aumento de } \\
\text { los niveles de } \\
\text { bilirrubina ó } \\
\text { fosfatasa } \\
\text { alcalina. } \\
\text {-Aumento de } \\
\text { los niveles de } \\
\text { GOT o GPT }\end{array}$ \\
\hline Pulmones & $\begin{array}{l}\text {-Bronquiolitis } \\
\text { obliterante } \\
\text { diagnosticada por } \\
\text { biopsia }\end{array}$ & $\begin{array}{l}\text {-BO diagnosticada } \\
\text { por PFR y radiología }^{c}\end{array}$ & & -BOOP \\
\hline $\begin{array}{l}\text { Aparato } \\
\text { locomotor }\end{array}$ & $\begin{array}{l}\text {-Fascitis } \\
\text {-Rigidez o } \\
\text { contractura } \\
\text { articular por } \\
\text { esclerosis }\end{array}$ & $\begin{array}{l}\text {-Miositis } \\
\text {-Polimiositis }\end{array}$ & $\begin{array}{l}\text {-Edema } \\
\text {-Calambres } \\
\text {-Artralgias o artritis }\end{array}$ & \\
\hline $\begin{array}{l}\text { Sistema } \\
\text { hematopoyético } \\
\text { e inmune }\end{array}$ & & & $\begin{array}{l}\text {-Trombocitopenia } \\
\text {-Eosinofilia } \\
\text {-Linfopenia } \\
\text { - } ९ \downarrow \text { Gammaglobulina } \\
\text {-AHAI o PTI }\end{array}$ & \\
\hline
\end{tabular}




\begin{tabular}{|l|l|l|}
\hline -Derrames pleural o \\
pericárdico \\
Otros & -Ascitis \\
& -Neuropatía periférica \\
& -Síndrome nefrótico \\
& -Miastenia gravis \\
& -Arritmias o \\
cardiomiopatía
\end{tabular}

AHAI: Anemia hemolítica autoinmune; PTI: Púrpura trombocitopénica Inmune. BOOP: Bronquiolitis obliterante con neumonía organizativa. a. se considera parte de la EICHc si se confirma el diagnóstico de la misma. b. Siempre se ha de descartar infección, toxicidad farmacológica ó neoplasia. c. Requiere biopsia ó confirmación radiológica (o test de Schirmer en caso de ojos).

La afectación de cada órgano se puntúa con una escala de 0 a 3, donde 0 ) indica normalidad, 1) lesión sin repercusión funcional, 2) lesión que conlleva limitación significativa de la capacidad para las actividades diarias y 3) lesión grave con discapacidad mayor (Tabla 3 y 4). Además se incluye una evaluación del estado general del paciente. La clasificación propuesta en el National Institutes of Health (NIH) Consensus Development Project pretende establecer 3 grupos de pacientes en función del número de órganos afectados por la EICR crónica y el grado de afectación de cada órgano, de manera que la EICR crónica se divide en: (1) Leve: afectación de uno o dos órganos (excepto el pulmón) sin repercusión funcional significativa (puntuación máxima de 1 en todos los órganos afectos); (2) Moderada: Al menos 1 órgano afecto con repercusión clínica funcional pero no grave (puntuación máxima de 2) ó 3 ó más órganos sin repercusión funcional significativa (puntuación máxima de 1 en todos los órganos afectos); (3) Grave: Indica limitación funcional grave (puntuación tres en cualquier órgano). Una puntuación $\geq 2$ pulmonar se considera grave.

El tratamiento sistémico está indicado en los pacientes con EICR crónica moderada o grave. Sin embargo, para la indicación de terapia sistémica hay que tener en 
cuenta otros factores de riesgo como plaquetopenia o el inicio progresivo o la naturaleza de la hemopatía por la cual se realizó el TPH. Iniciar un tratamiento inmunosupresor precoz podría evitar la progresión hacia las formas más graves de EICR crónica, mientras que la coexistencia de infecciones graves puede modificar esta decisión ${ }^{33}$.

Tabla 3. Otros indicadores, manifestaciones clínicas o complicaciones relacionadas con EICRc

\begin{tabular}{|c|c|c|c|c|}
\hline PUNTUACIÓN & $\mathbf{0}$ & 1 & 2 & 3 \\
\hline Estado general & $\begin{array}{l}\text {-Asintomático y } \\
\text { totalmente } \\
\text { activo (ECOG } \\
\text { 0, KPS } 100 \% \text { ) }\end{array}$ & $\begin{array}{l}\text {-Sintomático, } \\
\text { ambulatorio, } \\
\text { limitación actividad } \\
\text { física extenuante } \\
\text { (ECOG 1, KPS 80- } \\
90 \% \text { ) }\end{array}$ & $\begin{array}{l}\text {-Sintomático, } \\
\text { ambulatorio, se } \\
\text { vale por si } \\
\text { mismo, } \\
\text { deambula }> \\
50 \% \text { del tiempo } \\
(\text { ECOG } 2, \text { KPS } \\
60-70 \%)\end{array}$ & $\begin{array}{l}\text {-Sintomático, } \\
\text { dificultad para su } \\
\text { propio cuidado, } \\
>50 \% \text { en sillón- } \\
\text { cama (ECOG 3-4, } \\
\text { KPS }<60 \% \text { ) }\end{array}$ \\
\hline $\begin{array}{l}\text { Piel } \\
\text { - Rash maculopapular } \\
\text { - Liquen plano } \\
\text { - Ictiosis } \\
\text { - Hiperpigmentación. } \\
\text { - Hipopigmentación } \\
\text { - Queratosis pilaris } \\
\text { - Eritema } \\
\text { - Eritrodermia } \\
\text { - Poiquilodermia } \\
\text { - Esclerosis } \\
\text { - Prurito }\end{array}$ & -No síntomas & $\begin{array}{l}-<18 \% \mathrm{SC} \text { afecta } \\
\text { pero sin esclerosis }\end{array}$ & $\begin{array}{l}-19-50 \% \text { SC o } \\
\text { esclerosis } \\
\text { superficial ( se } \\
\text { puede pellizcar) }\end{array}$ & $\begin{array}{l}->50 \% \text { SC o } \\
\text { esclerosis profunda } \\
\text { o movilidad } \\
\text { limitada o prurito } \\
\text { grave. }\end{array}$ \\
\hline Boca & -No síntomas & $\begin{array}{l}\text {-Síntomas } \\
\text { moderados que no } \\
\text { dificultan la ingesta }\end{array}$ & $\begin{array}{l}\text {-Síntomas } \\
\text { moderados que } \\
\text { sí limitan } \\
\text { parcialmente }\end{array}$ & $\begin{array}{l}\text {-Síntomas graves } \\
\text { con limitación grave } \\
\text { de la ingesta. }\end{array}$ \\
\hline $\begin{array}{l}\text { Ojos } \\
\text { Test lagrimal (mm) } \\
->10 \\
-6-10 \\
-<5 \\
- \text { No realizado }\end{array}$ & -No síntomas & $\begin{array}{l}\text {-Sequedad ocular } \\
\text { leve que no afecta } \\
\text { actividad cotidiana o } \\
\text { queratoconjuntivitas } \\
\text { seca asintomática }\end{array}$ & $\begin{array}{l}\text {-Sequedad } \\
\text { ocular } \\
\text { moderada que } \\
\text { afecta algo a la } \\
\text { actividad } \\
\text { cotidiana sin } \\
\text { pérdida de la } \\
\text { agudeza visual }\end{array}$ & $\begin{array}{l}\text {-Sequedad ocular } \\
\text { grave que afecta } \\
\text { significativamente } \\
\text { la actividad } \\
\text { cotidiana o } \\
\text { incapacidad laboral } \\
\text { por síntomas } \\
\text { oculares o pérdida } \\
\text { de visión por } \\
\text { queratoconjuntivitis } \\
\text { seca }\end{array}$ \\
\hline
\end{tabular}

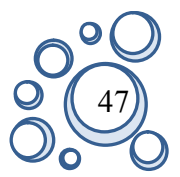




\begin{tabular}{|c|c|c|c|c|}
\hline $\begin{array}{l}\text { Tracto } \\
\text { gastrointestinal }\end{array}$ & -No síntomas & $\begin{array}{l}\text {-Síntomas como } \\
\text { disfagia, anorexia, } \\
\text { náuseas, vómitos, } \\
\text { dolor abdominal, } \\
\text { diarrea, sin pérdida } \\
\text { de peso }(<5 \%)\end{array}$ & $\begin{array}{l}\text {-Síntomas que } \\
\text { ocasionan } \\
\text { pérdida del 5- } \\
15 \%\end{array}$ & $\begin{array}{l}\text {-Síntomas con } \\
\text { pérdida }>15 \% \text { del } \\
\text { peso que requiera } \\
\text { aportes calóricos } \\
\text { adicionales }\end{array}$ \\
\hline Hígado & $\begin{array}{l}\text {-Función } \\
\text { hepática normal }\end{array}$ & $\begin{array}{l}-\uparrow \text { Bilirrubina, } \\
\text { Fosfatasa alcalina, } \\
\text { GOT o GPT }<2 \mathrm{x} \\
\text { límite alto }\end{array}$ & $\begin{array}{l}\text {-Bilirrubina }>3 \\
\text { mg/dL o B, } \\
\text { GOT/GPT 2-5 } \\
x\end{array}$ & $\begin{array}{l}\text {-Bilirrubina } \\
\text { GOT/GPT 5x }\end{array}$ \\
\hline $\begin{array}{l}\text { Pulmón } \\
\text {-FEV1 } \\
\text {-DLCO }\end{array}$ & $\begin{array}{l}\text {-No síntomas } \\
\text { FEV1 }>80 \%\end{array}$ & $\begin{array}{l}\text {-Disnea al subir un } \\
\text { tramo de escalera } \\
\text { FEV } 60-79 \%\end{array}$ & $\begin{array}{l}\text {-Disnea al } \\
\text { caminar sobre } \\
\text { llano }\end{array}$ & $\begin{array}{l}\text {-Disnea en reposo } \\
\text { FEV1 }<39 \%\end{array}$ \\
\hline Aparato locomotor & -No síntomas & $\begin{array}{l}\text {-Rigidez leve de las } \\
\text { extremidades, con } \\
\text { normalidad o leve } \\
\text { dificultad en los } \\
\text { movimientos }\end{array}$ & $\begin{array}{l}\text {-Rigidez o } \\
\text { contracturas o } \\
\text { fascitis con } \\
\text { moderada } \\
\text { limitación } \\
\text { funcional }\end{array}$ & $\begin{array}{l}\text {-Contracturas con } \\
\text { significativa } \\
\text { limitación } \\
\text { movilidad }\end{array}$ \\
\hline Genital & -No síntomas & $\begin{array}{l}\text {-Síntomas con } \\
\text { signos leves enla } \\
\text { exploración sin } \\
\text { repercusión en la } \\
\text { función sexual }\end{array}$ & $\begin{array}{l}\text {-Síntomas con } \\
\text { signos } \\
\text { moderados en } \\
\text { la exploración } \\
\text { con dispareunia } \\
\text { o disconfort al } \\
\text { examen } \\
\text { ginecológico }\end{array}$ & $\begin{array}{l}\text {-Síntomas con } \\
\text { signos avanzados } \\
\text { (estenosis, } \\
\text { aglutinación labial, } \\
\text { úlceras graves) y } \\
\text { dolor grave durante } \\
\text { el coito o } \\
\text { imposibilidad de } \\
\text { insertar el espéculo }\end{array}$ \\
\hline
\end{tabular}

Tabla 4. Valoración de la gravedad de la EICR crónica por órganos.

\begin{tabular}{|c|c|c|}
\hline Estenosis o membranas & Derrame peircárdico & Derrame pleural \\
esofágicas & Síndrome nefrótico & Neuropatía periférica \\
Ascitis (serositis) & Miocardiopatía & Eosinofilia $>500 / \mu \mathrm{L}$ \\
Miastenia gravis & Defectos de la conducción & Coronariopatía \\
Polimiositis & cardiaca & \\
Plaquetas $<100 \times 10^{9} / \mathrm{L}$ & Inicio progresivo & \\
\hline
\end{tabular}

\subsection{Criterios de respuesta al tratamiento en la EICR}

Hasta la fecha no existen criterios de respuesta de la EICR estandarizados. Ello supone un obstáculo importante en el diseño de ensayos clínicos y en el manejo de los pacientes con esta complicación. Las definiciones actuales de respuesta completa o 
parcial son subjetivas y poco reproducibles, variando ampliamente según diferentes ensayos clínicos.

El documento de consenso del National Institutes of Health Trials in Chronic GVHD propone una serie de medidas para cuantificar la actividad de la EICR en ensayos clínicos fase I-III que pretendan evaluar la respuesta al tratamiento. Estas medidas están dirigidas a la investigación y no deben de valorarse en el paciente de forma rutinaria., además deben de cumplir las siguientes condiciones:

- (1) Ser sencillas de usar en la consulta.

- (2) Ser aplicables tanto en niños como en adultos.

- (3) Centrarse en las manifestaciones de EICR más frecuentes

- (4) Usar medidas cuantitativas siempre que sea posible.

- (5) Medir por separado usando escalas adecuadas los síntomas, signos, valoración global, calidad de vida y estado general ${ }^{33}$.

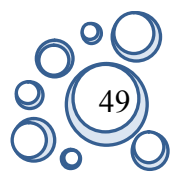




\section{ENFERMEDAD INJERTO CONTRA RECEPTOR}

\section{OCULAR (EICRO)}

\subsection{Fisiopatología}

La Enfermedad Injerto Contra Receptor ocular (EICRo) afecta entre un 40-60\% de los pacientes que han recibido un alotrasplante de progenitores hematopoyéticos, desarrollándose complicaciones oculares entre un 60-90\% de los casos ${ }^{49-52 .}$ La EICR ocular no suele producir una pérdida visual permanente, se ha demostrado que existe un curso clínicamente estable con buena agudeza visual, pero se produce un gran deterioro en la calidad de vida ${ }^{53}$ y en el desarrollo de las actividades diarias de los pacientes afectados.

La EICR ocular puede afectar a la superficie ocular y a las glándulas lagrimales mediante procesos de inflamación y cicatrización. Así mismo, se produce una disfunción de las glándulas de Meibomio.

Los hallazgos histológicos en la conjuntiva de los pacientes con EICR son similares a los que se encuentran en la piel, hígado y tracto gastrointestinal incluyendo disqueratosis con pérdida de células epiteliales, menor densidad de células caliciformes, exocitosis de linfocitos y necrosis en satélite epitelial con cuerpos apoptóticos, todo ello fenómenos característicos de la EICR. Desde el punto de vista inmunohistoquímico, Rojas y cols. pusieron de manifiesto que en la conjuntiva de los pacientes sometidos a un trasplante alogénico se pueden detectar en el epitelio células $\mathrm{CD}^{+}$y $\mathrm{CD} 14^{+}$, y en el estroma una mayor proporción de $\mathrm{LT}\left(\mathrm{CD}^{+}, \mathrm{CD}^{+}, \mathrm{CD}^{+}\right)$y células $\mathrm{CD} 14^{+}$con expresión de VLA-4 y LFA-1. En aquellos pacientes trasplantados que además presentan síntomas de ojo seco, aumenta el porcentaje de células $\mathrm{CD}_{1} 4^{+}$en epitelio y estroma $^{54}$, desvinculando a las células NK de este proceso. Todos estos macrófagos y el 
aumento de citocinas proinflamatorias participantes ${ }^{55}$ serían las responsables de la queratinización típica que aparece en la EICRo crónica.

A nivel de la glándula lagrimal se ha publicado que hasta la mitad de los pacientes que reciben un alo-TPH desarrollarán un ojo seco 6 meses más tarde o presentarán un empeoramiento en el ojo seco preexistente, que progresará rápidamente tras el inicio de los síntomas en la mayoría de los casos. El inicio de este cuadro de sequedad ocular suele coincidir con el descenso del tratamiento inmunosupresor administrado como profilaxis de la $\mathrm{EICR}^{56}$. Este cuadro ha sido descrito como una parte del denominado Síndrome Sjögren-like que también incluye xerostomía, sequedad vaginal y cutánea ${ }^{57}$. Para entender el origen del ojo seco que aparece tras el TCMH, es importante conocer la histopatología de la EICR crónica que abarca un proceso complejo el cual incluye varias fases. Inicialmente existe un infiltrado inflamatorio linfoplasmocitario que afecta al epitelio y a distintos tejidos glandulares, seguido por un proceso de fibrosis, estenosis, obliteración y atrofia de tejidos como sucede en el hígado, piel, intestino y pulmones. El cuadro evoluciona hacia una destrucción masiva de las glándulas túbulo-alveolares y de los conductos de las mismas, desarrollándose, entre otras alteraciones, un síndrome seco que afecta a las glándulas salivares y lagrimales. Los hallazgos histopatológicos indican que existe una participación muy importante en la patogenia de los fibroblastos estromales, puesto que, se ha observado que la gravedad del ojo seco está relacionada con el grado de fibrosis existente en la glándula lagrimal.

El mecanismo patogénico propuesto incluiría que las células $\mathrm{CD}^{+}$donantes actuarían sobre los fibroblastos produciendo una activación de los mismos, los cuales sintetizarían un exceso de matriz extracelular dando lugar a en una excesiva fibrosis intersticial que se acompaña de una pérdida progresiva de funcionalidad de la

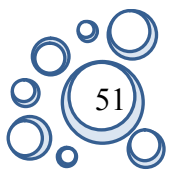


glándula ${ }^{58}$. Por tanto, el compromiso funcional de la glándula lagrimal debido a la EICR es el principal responsable del desarrollo de la queratoconjuntivitis seca en estos pacientes, a pesar de que existen otras causas que podrían contribuir al desarrollo de sequedad ocular tales como la irradiación corporal total, la toxicidad ocular de la quimioterapia y el tratamiento inmunosupresor ${ }^{59,60}$.

\section{- Histología de la glándula lagrimal en la EICRo aguda}

Los hallazgos histológicos ponen de manifiesto que en la EICR aguda aparece un fenómeno de éstasis del contenido glandular caracterizado por la presencia de material $\mathrm{PAS}^{+}$acumulado en los acinos, una dilatación de los conductos y una obliteración de la luz de los mismos, cambios similares a los observados en las vías biliares de los pacientes con EICR.

\section{- Histología de la glándula lagrimal en la EICRo crónica}

A pesar de que la presentación clínica es similar entre la EICR y el síndrome de Sjögren, hay diferencias significativas en los hallazgos patológicos de estas dos entidades. Para Ogawa y cols. ${ }^{61}$, el tejido glandular de los pacientes con EICR crónica presenta una serie de características histológicas peculiares las cuales van a permitir establecer la diferencia entre la EICR y el Síndrome de Sjögren. En primer lugar, existe un aumento de fibroblastos $\mathrm{CD} 34^{+}$los cuales coexisten con distintos grados de fibrosis intersticial especialmente a nivel del área periductal. En segundo lugar, se observan linfocitos $\mathrm{T} \mathrm{CD}^{+} \mathrm{y} \mathrm{CD}^{+}$a frecuencias similares pero con una distribución diferente; mientras que los linfocitos $\mathrm{T} \mathrm{CD}^{+}$infiltran el área periductal de la glándula, los linfocitos $\mathrm{CD}^{+}$se localizan infiltrando el epitelio acinar. En tercer lugar, para conocer el estado de activación de las células T en el área periductal e intraepitelial, se valora la 
expresión de la molécula CD154 que es el ligando de CD40, una molécula que se expresa sobre la superficie de las Células Presentadoras de Antígeno (CPA). CD154 también se expresa de forma transitoria sobre los linfocitos T CD4 y CD8 y por lo tanto se utiliza como marcador de células $\mathrm{T}$ que se han activado recientemente por la existencia de un estímulo antigénico. Por lo tanto, un aumento de células T CD154 en todos los conductos glandulares en pacientes con EICR crónica sugiere que los péptidos antigénicos son presentados de forma óptima por parte de las CPA periductales. En cuarto lugar, se han detectado células mononucleares que expresan HLA-DR, CD54, CD40, CD80 y CD86 en el intersticio glandular de todos los pacientes con EICR crónica y células mononucleares $\mathrm{CD} 6^{+}$alrededor de los conductos medianos y áreas perilobulares.

Los fibroblastos que rodean los conductos de tamaño medio expresan HLA-DR y CD54, siendo más numerosos los que expresan HLA-DR. Estos fibroblastos periductales coexisten en localización con células T CD4 y CD8. En el intersticio glandular de pacientes con EICR crónica existe una parte de fibroblastos que expresan CD40, CD80, o CD86 y una población de fibroblastos que expresan simultáneamente HLA-DR y CD40, CD80, CD86.

No se ha encontrado relación significativa entre la expresión de estas moléculas y el grado de sequedad ocular, tipo de donante, la radiación corporal total recibida, el momento de la biopsia tras el trasplante, profilaxis empleada o lesiones de la EICR crónica en otros órganos diferentes a los ojos. Sin embargo, si que se ha visto que los fibroblastos que expresan todas las moléculas a las cuales se han hecho referencia están presentes en pacientes con ojo seco severo a diferencia de los pacientes con ojo seco leve.

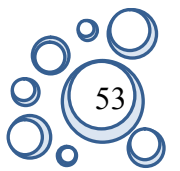


Yamazaki y Eyden ${ }^{62-64}$ han publicado recientemente que el aumento del número de fibroblastos en la glándula lagrimal de pacientes con EICR crónica son fibroblastos que tienen su origen de las zonas inter e intralobulillares. Otra posibilidad es que estos fibroblastos se originen a partir de células mesenquimales del donante. Por lo tanto, el área periductal es el sitio principal de activación de las células T en la glándula lagrimal en pacientes con EICR tras el trasplante. Esta afirmación se basa en la acumulación de células T CD4 y CD8, la expresión de CD154 por linfocitos T activados, células mononucleares, la presencia de fibroblastos estromales que expresan HLA-DR, CD54 y moléculas coestimuladoras localizados fundamentalmente en todos los conductos glandulares. Así mismo, los linfocitos $\mathrm{T}_{\mathrm{CD}}{ }^{+}$del área periductal podrían ejercer múltiples efectos como inducir cambios fenotípicos en los fibroblastos del estroma o promover la activación de linfocitos T CD8 citotóxicos. La interacción funcional entre linfocitos T CD4 y fibroblastos puede dar lugar a la proliferación y actuación de los fibroblastos a través del contacto célula-célula y factores solubles derivados de las células T activas tales como IL-4,6 o 17.

A. S. Hassan y cols. ${ }^{65}$ describieron cambios histológicos muy similares a los observados en humanos en la glándula lagrimal en modelos murinos de EICR. El infiltrado inflamatorio ha sido descrito de forma temprana a las dos semanas del trasplante. Este infiltrado se encuentra principalmente alrededor de los conductos de la glándula pero también impregna los septos que rodean al acino. El éstasis de las secreciones en la luz de los conductos así como la presencia de restos celulares en los conductos se encuentran también aumentados en los especímenes sometidos a trasplante alogénico respecto a los controles a las 4 semanas y aumenta de forma significativa a las 6 semanas. El infiltrado leucocitario observado en los ratones a las 6 semanas tras el trasplante alogénico esta constituido predominantemente por células $\mathrm{CD}^{+}$ 
(primordialmente $\mathrm{CD}^{+}$y en menor medida $\mathrm{CD} 4^{+}$). También se han observado células mononuclares al emplear el marcador CD68. No existe tinción significativa de CD20 de linfocitos B y tampoco neutrófilos.

Sale y cols. ${ }^{66}$ han sugerido que el daño de los conductos y la obliteración de la luz de los mismos son cambios precoces que aparecen en las glándulas salivares y lagrimales en pacientes con EICR crónica y que la fibrosis es un cambio secundario a este proceso funcional obstructivo.

Así mismo, se ha observado una multidelaminación de la membrana basal de los vasos sanguíneos que puede ser el resultado de un daño repetido seguido de un proceso de reparación de las paredes vasculares. Este fenómeno se describe con frecuencia en pacientes con vasculopatía sistémica como por ejemplo ocurre en la diabetes mellitus o en la artritis reumatoide ${ }^{67}$. Hay que tener en cuenta que la rotura de la membrana basal observada en los pacientes que reciben trasplantes alogénicos es multifactorial y que puede ser debida a otro factores como el empleo de fármacos antitumorales, inmunosupresores o bien por una infección de citomegalovirus ${ }^{68}$. Se ha postulado que esta rotura puede ser uno de los procesos iniciales implicados en la patogénesis del ojo seco puesto que se ha observado la formación de múltiples capas así como el adelgazamiento de la membrana basal de los conductos glandulares en estadios iniciales, constituyendo una de las características histológicas que aparecen en la glándula lagrimal de pacientes con $\mathrm{EICR}^{69}$. Se ha descrito una correlación entre el grado de adelgazamiento de la membrana basal y la severidad del ojo seco. La rotura de la membrana basal de los conductos y la posterior infiltración de las células $\mathrm{T}$ en los pacientes con ojo seco leve, podrían justificar que la multidelaminación de la membrana basal sea debida a la producción acelerada de matriz extracelular por parte de los fibroblastos y células mioepiteliales tras tomar contacto con las células $\mathrm{T}$ infiltrantes.

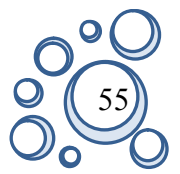


Muchos de los pacientes con EICR crónica reciben una radiación corporal total como régimen de acondicionamiento previo al trasplante. Por lo tanto, no se puede excluir la posibilidad de que la fibrosis y la alteración de la membrana basal observada en los pacientes con EICR crónica sometidos a una radiación corporal total previa sea debida a esta. Para demostrarlo, Sale y cols. ${ }^{66}$ realizaron diversos estudios y no hallaron una correlación significativa entre la radiación corporal total y los hallazgos histopatológicos los cuales incluyen cambios en el epitelio de los conductos y la infiltración linfocítica de las paredes de los mismos. Además, se ha descrito exceso de fibrosis y adelgazamiento de la membrana basal de los vasos, lóbulos y conductos en pacientes que no han recibido radiación corporal.

A modo esquemático, Owaga y cols. ${ }^{70}$ en 2008 resumieron los eventos que van sucediendo en los pacientes con EICR crónica y que conducen a la fibrosis de la glándula lagrimal y de la conjuntiva, desembocando finalmente en una impotencia funcional de la misma (Fig. 5). Primero, existe una rotura de la lámina basal del vaso sanguíneo que favorece la migración de los linfocitos $\mathrm{T}$ y de los fibroblastos derivados del donante hacia los tejidos oculares, tal vez debido a las señales de homing liberadas por parte de la respuesta inmunológica. Estas células T poco después son activadas y migran hacia las zonas periductales donde interaccionan con el epitelio de la glándula lagrimal promoviendo el paso de estas células de un fenotipo mioepitelial a un fenotipo mesenquimal, convirtiéndose en células presentadoras de $\mathrm{HSP} 47^{70}$, las cuales facilitan la producción de haces de colágeno por el mioepitelio (Fig. 5). Al mismo tiempo, inducido por las citocinas liberadas por las células inflamatorias, los fibroblastos derivados del donante son activados y proliferan. Estos fibroblastos activados, promueven la expresión de altos niveles de HSP47, lo cual conduce a una exacerbación de la producción de matriz extracelular. Este exceso de matriz contribuye a la fibrosis 
intersticial que se traduce en una pérdida de la función de la glándula lagrimal. Los fibroblastos derivados del donante son incapaces de transformarse en miofibroblastos y pueden tener una esperanza de vida prolongada durante la cual continúan generando más matriz extracelular. (Fig. 5).

A este esquema habría que sumar las aportaciones de trabajos anteriores, que sugieren que en la fisiopatología de la EICR crónica podrían participar células $\mathrm{T}$ autorreactivas que han escapado al proceso de selección negativa que se lleva a cabo en el timo el cual se encuentra alterado por los distintos regimenes de acondicionamiento que reciben los pacientes o bien por la existencia previa de EICR aguda. Los fibroblastos donantes expresan HLA-DR y moléculas coestimuladoras que pueden actuar como CPA desencadenando la EICR crónica $^{70}$ (Fig. 5).

\section{REPRESENTACIÓN ESQUÉMATICA DE LOS PROCESOS DE FIBROSIS EN LA GLÁNDULA LAGRIMAL EN ENFERMOS CON EICHc}

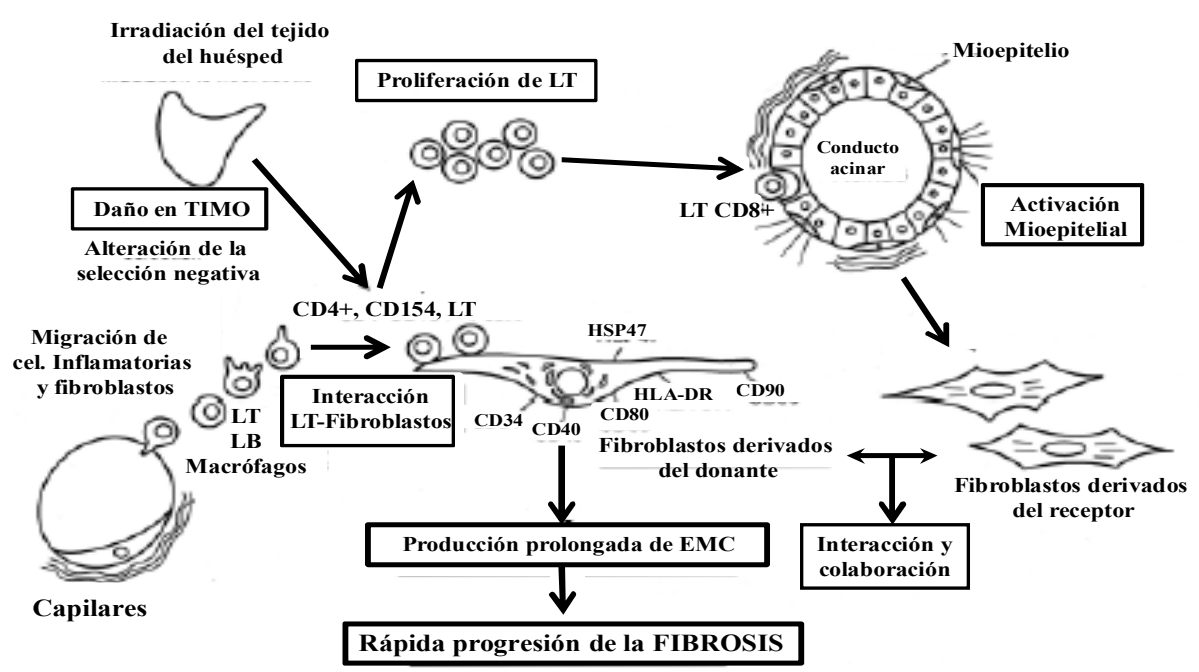

Adaptado de Ogawa Y et al. Inflammation and regeneration. 2008

Fig. 5. Representación esquemática de los procesos de fibrosis en la glándula lagrimal de los enfermos con EICRo. Adaptado de Ogawa Y y cols. Inflammation and regeneration. 2008.

En caso de que sea preciso, las biopsias diagnósticas de mucosa lagrimal deben de ser biopsias incisionales, de zona no ulcerada y que incluyan de 5 a 10 lóbulos

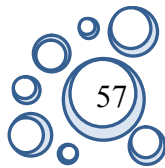


glandulares. Se deben realizar entre 16 y 20 cortes seriados teñidos con hematosilinaeosina.

A la hora de su interpretación, existen unos criterios mínimos para el diagnóstico de actividad en EICR crónica (infiltración linfocitaria con apoptosis variable) y unos criterios específicos tales como infiltración inflamatoria y daño del epitelio de los ductos intralobulares, fibroplasia en el estroma periductal e inflamación con desestructuración del tejido glandular ${ }^{33}$

La citología de impresión es una técnica que permite recoger las capas más superficiales del epitelio córneo-conjuntival mediante la aplicación de papeles de filtro. Esta técnica no es invasiva, es fácil de realizar, causa mínimas molestias al paciente y puede ser utilizada a lo largo del tiempo. Entre las virtudes de la citología de impresión destaca el mantenimiento de la morfología de la superficie córneo-conjuntival, la relación célula- célula y la interacción entre estas células epiteliales y otros componentes celulares (células inflamatorias, etc.), así como conocer la morfología celular permitiendo recoger hasta tres capas de células de la superficie conjuntival y una corneal. Aunque el proceso de metaplasia escamosa es continuo, se ha dividido en diversos grados para una mejor comprensión. Nelson desarrolló una escala de cuatro grados, basándose en el número de células caliciformes y el aspecto de las células epiteliales. Los grados oscilan entre el 0 y el 3, siendo el 0 normal y el 3 muy alterado.

Si bien la queratinización es fácilmente reconocible mediante exámenes biomicroscopicos, la metaplasia escamosa, que es un fenómeno anterior a la queratinización, solo puede ser demostrada mediante la citología de impresión, por lo que se trata de una prueba de gran valor diagnóstico permitiendo descubrir la enfermedad en sus fases más tempranas, antes de la aparición de algún signo clínico, 
pudiendo adelantar el inicio de un determinado tratamiento y evitar así la aparición de síntomas en el paciente.

El test de Schirmer constituye el estándar de excelencia en el diagnóstico de la EICR crónica. Existen estudios que hacen especial hincapié en la realización del test de Schirmer con estimulación nasal para optimizar el diagnóstico de ojo seco asociado a EICR crónica junto con una correcta evaluación de la superficie ocular ${ }^{71-74}$. La proporción de falsos positivos en el diagnóstico del ojo seco debido a EICR crónica empleando el test de Schirmer sin estimulación nasal es del 19,4\% y la de falsos negativos 36,4\%. El valor medio del test de Schirmer con estimulación nasal se correlaciona bien en pacientes con la EICR crónica, sin embargo no hay una correlación clara entre el test de Schirmer sin estimulación nasal y la EICR crónica ${ }^{56}$.

La córnea y limbo corneoescleral están afectados de forma predominante en la EICRo. El síndrome de ojo seco secundario a EICR presenta diversas manifestaciones clínicas entre las que destaca la queratoconjuntivitis seca que puede evolucionar hacia la opacidad corneal. La córnea (epitelio, estroma y endotelio), es la puerta de entrada de las imágenes al ojo y juega un papel crítico por sus condiciones especiales de trasparencia y avascularidad. El limbo esclerocorneal que constituye una zona de transición entre la córnea y la conjuntiva tiene gran importancia en la regeneración del epitelio corneal porque posee células madre.

Actualmente, no existe un tratamiento etiológico para los pacientes que sufren EICRo. Por este motivo, la investigación en la búsqueda de nuevas estrategias terapéuticas que puedan aminorar la sintomatología e incrementar la calidad de vida de los pacientes con EICRo, resulta absolutamente decisiva. Por este motivo, uno de las primeros objetivos de nuestro grupo de investigación fue la generación de un modelo murino de EICRo. En 2011 Lorenzo y cols. ${ }^{224}$, describieron las características

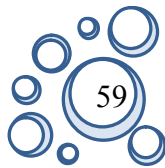


histopatológicas en córnea y limbo que constituyen la base de la fisiopatología de la enfermedad a nivel ocular. Se observó en el limbo y en la córnea fenómenos de satelitosis, así como cuerpos apoptóticos, vacuolización e infiltrado inflamatorio tanto en epitelio como en estroma, manteniéndose integro el endotelio.

La queratitis y el síndrome de ojo seco grave que sufren los enfermos con EICRo se justifican por los cambios anatomopatológicos que se producen a nivel corneal. También existe una pérdida de transparencia corneal y limbar al existir edema estromal difuso lo cual conlleva una disminución de la agudeza visual. Así mismo, un epitelio alterado provoca irregularidades corneales las cuales facilitan la aparición de úlceras corneales recidivantes y de queratitis, aumentando el riesgo potencial de infecciones.

En este trabajo, Lorenzo y cols. ${ }^{224}$, también estudiaron el limbo esclerocorneal que juega un importante papel en la regeneración del epitelio corneal. Este epitelio límbico posee un mayor potencial de proliferación que el epitelio corneal central y periférico, contiene una población de células madre cuyas células hijas colonizarán la córnea $^{75}$. Por tanto, la insuficiencia o la destrucción total del limbo conducen a una disminución de la capacidad de regeneración epitelial, de lo que se deduce que las células madre localizadas en el limbo son las responsables de la regeneración corneal $^{76,77}$. Cuando por consecuencia de la EICRo disminuye el número de células madre en el limbo, las células epiteliales de la conjuntiva pueden invadir la córnea induciendo una pérdida de la transparencia corneal, un proceso inflamatorio crónico, neovascularización y la aparición de úlceras corneales debidas a un epitelio de escasa calidad (Fig.6) ${ }^{78}$ 


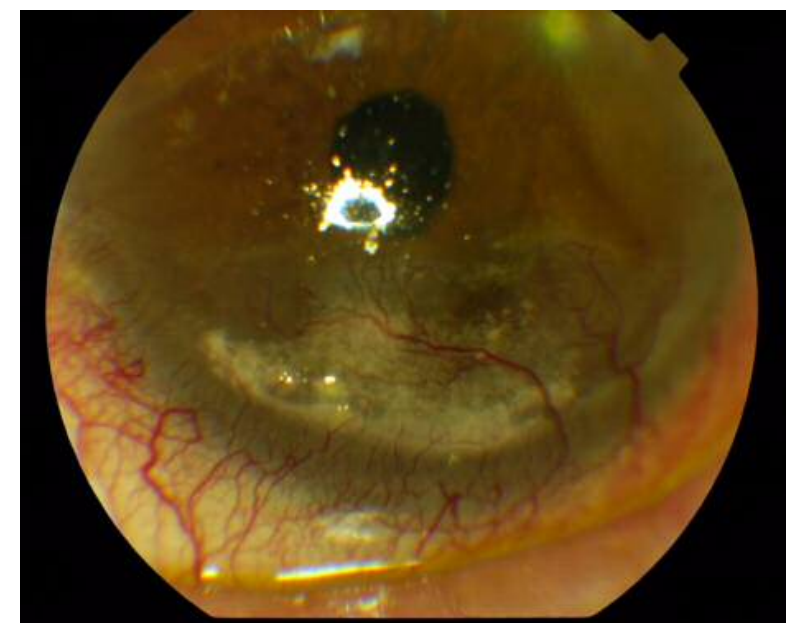

Fig.6. Neovascularización corneal inferior secundaria a insuficiencia limbar acompañado de adelgazamiento periférico corneal.

\subsection{Manifestaciones clínicas de la EICRo}

Una de las complicaciones más relevantes del alo-TPH es el desarrollo de EICR (ocurre entre un 20-70\% de los casos), además, la EICR genera una serie de problemas relacionados cómo puede ser una deficiente función del injerto hematopoyético postrasplante (aproximadamente un $20 \%$ de los pacientes). Entre el 40 y el $90 \%$ de los pacientes con EICR desarrollan lesiones oculares ${ }^{79,80}$, sobre todo en aquellos que sufren EICR crónica ${ }^{81}$. En este cuadro se involucran casi todas las estructuras oculares: párpados, glándula lagrimal, conjuntiva, córnea, vítreo, coroides y nervio óptico. Las estructuras que más frecuentemente se ven afectadas por la EICR son la glándula lagrimal y la superficie ocular ${ }^{82}$.

- Durante la fase aguda de la EICRo puede aparecer una conjuntivitis pseudomembranosa cuya aparición es un signo de mal pronóstico. Menos frecuentemente se han descrito otras manifestaciones como son el glaucoma secundario o la escleritis posterior con desprendimiento coroideo. También se han descrito la aparición de infecciones por virus del herpes simple ${ }^{56}$ en los distintos segmentos oculares. 
- Durante la fase crónica de la EICRo se puede desarrollar una disfunción de las glándulas de Meibomio o una queratoconjuntivitis seca y las complicaciones corneales secundarias que llevan asociadas. La aparición de cataratas, aunque es una complicación potencial, se observa con menos frecuencia en la actualidad debido a los modernos regimenes de acondicionamiento y la reducción en el empleo de corticoides sistémicos. Son muy raras las ocasiones que aparecen casos de uveítis, se piensa que derivados del ataque directo de los linfocitos del donante hacia los antígenos del receptor ${ }^{50}$. En la retina se pueden encontrar exudados algodonosos, hemorragias retinianas, depósitos lipídicos en el contexto de una retinopatía isquémica y proliferativa, edema macular quístico e incluso retinitis infecciosas ${ }^{83-86}$. También se han descrito en algunos casos la afectación de la órbita e incluso del nervio óptico ${ }^{57,60}$.

\subsubsection{Superficie ocular}

La complicación más frecuente de los pacientes que desarrollan EICRo es la querotoconjuntivitis sicca (Fig.7). Esta es más frecuente en los pacientes con EICRo crónica $^{87}$. Dado que su incidencia es muy alta (69-77\% de los pacientes con EICRo) algunos autores han correlacionado directamente la gravedad del ojo seco con la severidad de la EICR ${ }^{51,88}$.

El ojo seco se diagnostica mediante la realización de una adecuada historia clínica, un examen bajo lámpara de hendidura buscando el tiempo de ruptura de la película lagrimal (BUT $\leq 10$ segudos), la tinción con fluoresceína, verde de lisamina y rosa de bengala y el test de Schirmer además de otras pruebas complementarias como el hilo rojo fenol, el análisis bioquímico de la lágrima, la citología de impresión y la videoqueratoscopía $^{89}$. En casos de dudosa etiología, se pueden realizar raspados corneales y conjuntivales para estudios microbiológicos. Otras pruebas más recientes 
incluyen la medición de la osmolaridad de la película lagrimal y el empleo de la microscopía confocal ${ }^{90}$.

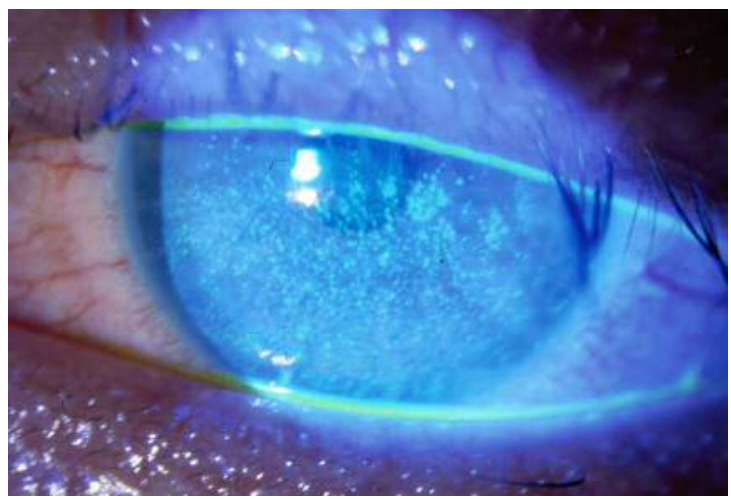

Fig.7. Queratopatía punctata superficial derivada de la queratoconjuntivitis sicca.

En relación a la osmolaridad de la película lagrimal, aunque algunos estudios han demostrado una excelente correlación entre las mediciones realizadas y el síndrome de ojo seco, otros muchos no lo recogen; por lo tanto, la medida de la osmolaridad lagrimal no debe utilizarse como un único indicador de enfermedad de ojo seco; tampoco se puede establecer el diagnóstico definitivo de ojo seco mediante una sola medición de la osmolaridad lagrimal. Sin embargo, el empleo de mediciones seriadas sobre el mismo paciente, puede ser útil en la monitorización con la finalidad de valorar el éxito del tratamiento instaurado.

La evaluación sintomática puede realizarse mediante cuestionarios relativos a la calidad de vida como el Ocular Surface Disease Index (OSDI) cuyos valores son superiores en pacientes con EICRo crónica que en pacientes en periodo pre- o postrasplante sin EICR.

La córnea y la conjuntiva son las dianas inmunológicas iniciales de la EICRo, de forma que la primera manifestación que aparece en la superficie ocular es una conjuntivitis no infecciosa pseudomembranosa aislada o asociada a otras alteraciones de

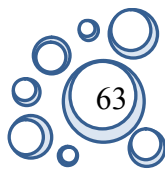


la superficie. Los sistemas de clasificación de la conjuntivitis en la EICR ocular se engloban en 4 grados en función de los hallazgos y según sea aguda o crónica (Tabla 5) 91,92

Tabla 5. Clasificación conjuntival en la EICR aguda y crónica

\begin{tabular}{l} 
CLASIFICACIÓN DE LA CONJUNTIVITIS EN LA EICRo AGUDA \\
0. Nada \\
1. Hiperemia \\
2. Hiperemia con exudación serosanguinolenta \\
3. Conjuntivitis pseudomembranosa \\
4. Conjuntivitis pseudomembranosa con descamación epitelial de la córnea \\
$\qquad$ CLASIFICACIÓN DE LA CONJUNTIVITIS DE LA EICRo CRÓNICA \\
\hline 0. Ninguno \\
\hline 1. Hiperemia \\
2. Cambios fibrovasculares en la conjuntiva palpebral con o sin descamación epitelial \\
total \\
\hline 4. Participación de > 75\% de la superficie total con o sin entropión cicatricial \\
\hline
\end{tabular}

Recientemente, Calonge y cols., han diseñado un modelo predictivo basado en el análisis de biomarcadores presentes en la lágrima para facilitar el diagnóstico de la EICRo crónica ${ }^{93}$. Este análisis de las citocinas lagrimales ha revelado la existencia de unos niveles de EGF (Epidermal Growth Factor) y de IP-10/ CXCL10 inferiores en las lágrimas de aquellos pacientes con EICRo crónica que en el caso de los controles sanos. Además, se ha observado que en las células epiteliales de la conjuntiva de los pacientes con EICRo crónica la expresión de los genes del receptor del EGF (EGFR) es 2,6 veces inferior a la que existe en los sujetos sanos ${ }^{94}$, lo cual confirma lo anteriormente expuesto 
en relación a los bajos valores de EGF. IP-10/CXCL10 es una molécula quimiotáctica que ejerce su efecto sobre los linfocitos $\mathrm{T}$, las células NK y los monocitos ${ }^{95} \operatorname{los}$ cuales también se encuentran disminuidos en las secreciones lagrimales de los pacientes con EICRo crónica. Los linfocitos T activados producen la liberación de diversas citocinas tales como CXCL 9, IP-10/CXCL10, CXCL 11 que a su vez colaboran en el reclutamiento de células $\mathrm{T} \mathrm{CXCR}^{+}$dando todo ello lugar al daño tisular característico de la EICR $^{96}$. La importancia del papel de la PI-10/CXCL10 en pacientes con EICR ha sido descrita con anterioridad por diversos autores.

Westekemper y cols. ${ }^{97}$, demostraron mediante la realización de la técnica de PCR sobre biopsias conjuntivales de individuos sanos y con EICRo crónica, que la PI10/CXCL10, CXCL9, CXCL11 así como su receptor CXCR3, se encontraban sobreexpresados en el tejido conjuntival de los pacientes con EICRo crónica. Aunque estos hallazgos no son específicos de la EICRo crónica, el seguimiento cuantitativo de estas citocinas y de sus receptores puede ser considerado como un método diagnostico útil en el caso de la EICR crónica conjuntival permitiendo a su vez encontrar terapias alternativas y dirigidas hacia estas dianas ${ }^{97}$.

Así mismo, también se ha hallado un aumento de los niveles de IL-1Ra, IL8/CXCL8 e IL-10 en el fluido lagrimal de los pacientes afectados por EICRo crónica ${ }^{98-}$ 102. Uno de los principales mediadores en la respuesta inflamatoria es IL-8/CXCL 8 y se ha visto que existe una clara correlación entre la elevación de sus niveles y la aparición de signos clínicos más intensos en pacientes con EICR aguda ${ }^{103}$ observándose niveles hasta 5 veces superiores en el epitelio conjuntival de pacientes enfermos respecto a los controles $\operatorname{sanos}^{94}$; esta molécula está fuertemente asociada con la mortalidad, la refractariedad al tratamiento y el riesgo de desarrollar EICR ${ }^{104,105}$.

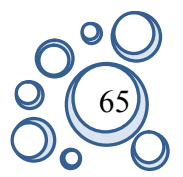


Riemens y cols. describieron la existencia de un incremento de los niveles de IFN- $\gamma$ y de IL-6 lagrimal en pacientes con EICRo y establecieron una asociación entre los niveles de estas citocinas y las características clínicas presentes en la exploración de cada paciente, de tal modo que las concentraciones de IL-6 se correlacionaban con la sensación de cuerpo extraño, con el cuestionario OSDI y con la alteración de la tinción corneal, y las de IFN- $\gamma$ se asociaban con alteración en los valores del test de Schirmer y en el test de ruptura de la película lagrimal (TBUT) ${ }^{106}$.

Se desconoce cual es la fuente exacta de producción de IL-6 en la etiopatogenía del síndrome de ojo seco. Se sabe que la IL-6 puede ser producida por distintas células tales como monocitos, macrófagos y fibroblastos ${ }^{107}$ y que interviene como potente mediador en la inflamación local y sistémica ejerciendo efecto sobre los Linfocitos B y $\mathrm{T}^{107-109}$; también participa en la diferenciación de células Th17 las cuales son unas células reguladoras que juegan un papel relevante en la respuesta autoinmune y por lo tanto en el desarrollo del la EICRo aguda ${ }^{10,111}$. Mediante el empleo de modelos murinos, se ha observado cómo el bloqueo de la señal de IL-6 conduce a una atenuación drástica de la respuesta de las células Th17 y por extensión, reduce la aparición de EICRo ${ }^{108,111,112}$.

Otras citocinas estudiadas son la IL-2, IL-4, IL-6, IL-10, IL-17A e TNF $\alpha$. Todas ellas elevadas en pacientes con EICRo pero sin una correlación significativa entre sus niveles y los parámetros clínicos ${ }^{113}$ a diferencia de lo que ocurre con citocinas tales como el EGF, IL-2Ra, IL-8/CXCL8 e IP-10/CXCL10 las cuales sí muestran la existencia de una correlación entre sus niveles y los parámetros clínicos.

Tras numerosos estudios, se ha observado como los modelos basados en múltiples biomarcadores ayudan a mejorar el rendimiento en comparación a aquellos que se centran la determinación de una solo molécula. Por ello, el modelo predictivo 
planteado por Calonge y cols., basado en la determinación lagrimal de IL-8/CXCL8 y IP-10/CXCL10 $0^{93}$ puede constituir una herramienta muy útil para el desarrollo de la práctica clínica habitual dentro del manejo de la EICRo crónica, debido al fácil acceso que se dispone del fluido lagrimal ${ }^{114}$, en detrimento de la actual citología de impresión conjuntival que es más invasiva y menos específica.

Otros procesos inflamatorios descritos en la superficie ocular son la epiescleritis y la queratoconjuntivitis límbica superior a las cuales se pueden asociar un simbléfaron de la conjuntiva palpebral y de los fondos de saco dando lugar a una alteración anatómica y función palpebral (entropión, ectropión, atrofia de las glándulas de Meibomio y estenosis de los puntos lagrimales). La presencia de signos conjuntivales unida a una disfunción de las glándulas de Meibomio en pacientes con EICR puede ser de otra etiología como la iatrogénica o la secundaria a terapias de acondicionamiento e infecciones.

\subsection{Estrategias terapéuticas actuales en la EICRo}

Las opciones terapéuticas actuales en el tratamiento de la enfermedad injerto contra receptor ocular se basan en cuatro principios fundamentales:

1.- Preservar la lágrima y lubricar la superficie ocular.

2.- Reducir de la carga inflamatoria de la superficie ocular.

3.- Prevenir la evaporación de la lágrima.

4.- Proporcionar soporte al epitelio corneal.

\subsubsection{Lubricación y conservación de la lágrima}

- Constituye el primer escalón terapéutico en caso de queratitis asociada a ojo seco. En estos casos se recomienda llevar a cabo una lubricación mediante lágrimas artificiales sin conservantes según las necesidades del paciente. En caso de que se

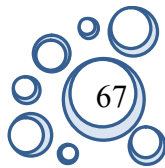


requieran aplicaciones muy frecuentes, se pueden recurrir a lágrimas más viscosas, tales como geles oftálmicos que persistan durante más tiempo en contacto con la superficie ocular. El uso frecuente de lágrimas artificiales permite además de lubricar, diluir los mediadores inflamatorios de la superficie ${ }^{115}$.

- La acetilcisteína al 5-10\% tópica se puede emplear en casos de queratitis filamentosa debido a sus propiedades mucolíticas.

- Los secretagogos orales, tales como la Pilocarpina o Cevimeline (agonistas muscarínicos selectivos) pueden resultar efectivos al estimular la secreción de la porción acuosa de la película lagrimal; sin embargo, su uso no se ha demostrado efectivo en el caso de EICRo crónica y además conlleva unos efectos secundarios y tóxicos en pacientes con abundante medicación sistémica. En la misma línea se deben evitar fármacos que induzcan xerosis como antihistamínicos, antidepresivos tricíclicos y derivados mórficos.

- La conservación de la lágrima también se puede lograr mediante la oclusión de los puntos lagrimales que se puede llevar a cabo de forma temporal a través de tapones no perforados de silicona, o bien de forma permanente mediante cauterización térmica de los mismos. La decisión de qué tipo de oclusión emplear se tomará en función del resultado del test de Schirmer y de la afectación clínica del paciente. La pérdida de los tapones de silicona es factible en un bajo porcentaje de pacientes debido a la fibrosis subepitelial de los puntos lagrimales. En estos casos, cuando existe una pérdida constante de los tapones, se recomienda realizar una cauterización térmica de los $\operatorname{mismos}^{116}$.

\subsubsection{Reducción de la carga inflamatoria de la superficie ocular}

- La ciclosporina tópica al 1\% (CsA) se ha empleado con éxito en pacientes con EICRo y queratoconjuntivitis sicca refractaria a tratamientos convencionales basados en 
lubricación y corticoides tópicos ${ }^{117,118}$ La ciclosporina actúa inhibiendo la proliferación de células $\mathrm{T}$, así como, la producción y liberación de citocinas por parte de las células $\mathrm{T}$ activadas en la conjuntiva. Durante su empleo, se ha demostrado que existe un aumento en el número de células caliciformes y en la tasa de renovación del epitelio conjuntival $^{119,120}$. La administración tópica de ciclosporina alcanza mayores concentraciones en conjuntiva y humor acuoso que administrada de forma sistémica ${ }^{121}$.

- Se recomienda el uso de corticoides tópicos en la EICRo crónica cuando existen cambios cicatriciales. Las principales complicaciones asociadas a un tratamiento de larga duración son el aumento de la presión intraocular (PIO) y el desarrollo de cataratas subcapsulares posteriores, además debido a sus propiedades, están contraindicados en pacientes con defectos epiteliales, adelgazamientos corneales o infiltrados corneales debido al alto riesgo de infección.

- El antagonista del receptor de la IL-1 (IL-1Ra, Anakinra) por vía tópica se ha empleado en modelos murinos de ojo seco con el fin de reducir la inflamación obteniendo resultados prometedores ${ }^{122}$. La aplicación a nivel clínico de IL-1Ra al 2,5\% en pacientes con EICRo ha demostrado mejoría en el tiempo de ruptura lagrimal y una mejoría en el OSDI.

- El tacrólimus (FK506) es un antibiótico de la familia de los macrólidos y tiene un mecanismo de acción y unos parámetros farmacocinéticos similares a la Ciclosporina, por ello también puede resultar útil en enfermedades de la superficie ocular. Existe experiencia en el uso de tacrólimus en ungüento al $0,005 \%{ }^{123}$ en pacientes intolerantes a otros fármacos como la ciclosporina tópica con buenos resultados clínicos, puesto que los pacientes refieren una disminución subjetiva de las molestias oculares, y funcionales debido a que esta preparación farmacéutica se caracteriza por tener una gran penetrancia a nivel corneal y conjuntival logrando una

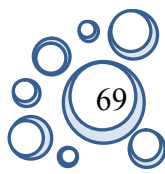


mayor inmunosupresión y por lo tanto una mayor eficacia terapéutica. Además su aplicación local evita efectos adversos.

- También se han descrito los efectos beneficiosos en el uso de ácido retinoico tópico en pacientes con EICRo crónica, dado que revierte la queratinización conjuntival de forma eficaz ${ }^{124}$.

\subsubsection{Soporte del epitelio corneal}

- El suero autólogo tópico ha demostrado ser un tratamiento muy bien tolerado y seguro, con escasos efectos secundarios ${ }^{125}$, en el tratamiento del ojo seco severo asociado a EICRo crónica. Este suero es rico en factores que favorecen el desarrollo epitelial como la albúmina, vitaminas, la fibronectina y el TGF- $\beta$, que son esenciales para la proliferación, diferenciación, maduración y el mantenimiento de la integridad del epitelio corneal y de la superficie conjuntival. Además, tiene un efecto bacterióstatico puesto que en su composición contiene inmunoglobulinas y lisozimas ${ }^{126}$.

-En algunos casos, se ha descrito el uso de lentes de contacto blandas a modo de vendaje mejorando la sintomatología, aunque se ha observado que el uso de lentes de hidrogel de silicona de forma prolongada aumenta el riesgo de infección sobre todo en pacientes con epiteliopatía activa y/o inmunosupresión asociada, y no mejoran las características de la superficie ocular dañada. Las lentes esclerales y PROSE (Prosthetic Replacement of Ocular Surface Ecosystem) son lentes rígidas gas permeable de gran diámetro que recubren la mayor parte de la superficie ocular (Fig. 8). Estas lentes de apoyo conjuntival recubren la esclera creando un espacio entre la cara posterior de la lente y el epitelio corneal que funciona a modo de reservorio proporcionando una hidratación continua y permitiendo la resolución de epiteliopatías ${ }^{127}$. 


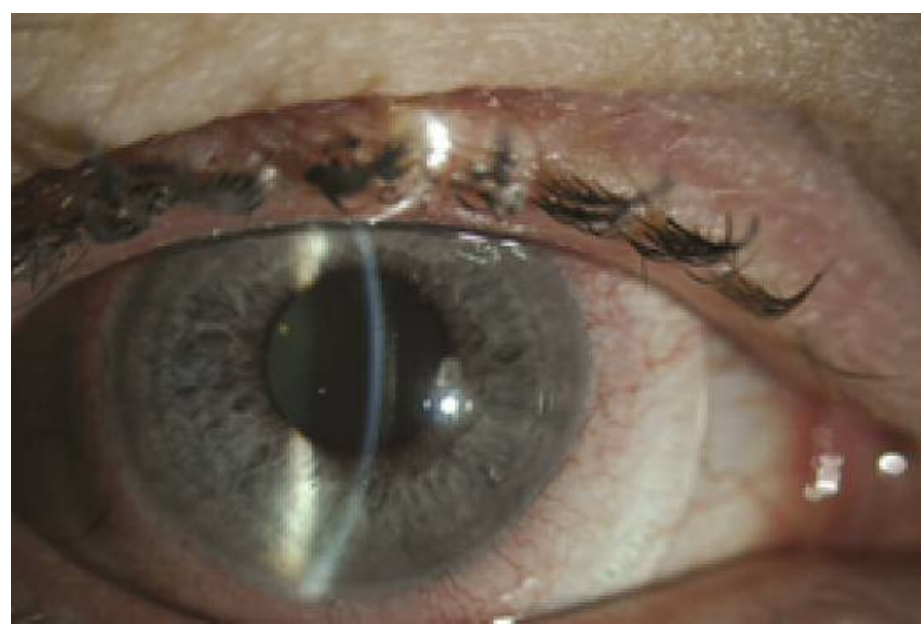

Fig. 8. Tratamiento PROSE. Lente escleral en paciente con ojo seco severo secundario a EICR crónica.

- Recientemente, se ha incorporado el Plasma Rico en Factores de Crecimiento $(P R G F)$ como arma terapéutica en el contexto del ojo seco moderado-severo refractario.

El PRGF se basa en la utilización de las plaquetas como vehículo para la liberación controlada de factores de crecimiento que intervienen en la comunicación celular ya que transmiten su información al interaccionar con los receptores situados en la membrana celular. Además actúan simultáneamente sobre distintos tipos celulares estimulando procesos biológicos como la quimiotaxis, la proliferación, la diferenciación celular o la angiogénesis entre otros ${ }^{128}$. En la actualidad, se ha desarrollado la tecnología ENDORET ${ }^{\circledR}$ la cual facilita los medios necesarios para el aislamiento y la concentración de estos factores de la sangre implicados en la regeneración tisular, así como para su adecuada aplicación en el lugar de la lesión ${ }^{129,130}$. Entre sus mecanismos de acción destacan la disminución el dolor y la inflamación ${ }^{131}$, el incremento de la proliferación celular ${ }^{132}$ y la secreción autocrina y paracrina ${ }^{133}$ y la protección frente a la fibrosis ${ }^{134}$. Esta tecnología permite elaborar diversas formulaciones terapéuticas (colirio, coágulo, inyectable y/o membrana de fibrina) en función de los objetivos clínicos que se deseen alcanzar $^{135}$. 
- El uso de membrana amniótica en la EICRo también es potencialmente útil. Sus efectos clínicos son múltiples, entre ellos destaca el efecto tectónico en caso de defectos estromales extensos ${ }^{136}$, el favorecimiento de la epitelización (migración y adhesión) ${ }^{137}$, la disminución de la inflamación, la neovascularización y del tejido cicatricial $^{138}$, el efecto neuroprotector ${ }^{139}$, el efecto antiálgico y la constitución de una barrera antimicrobiana. Sus aplicaciones pueden ser sobre estructuras conjuntivales y/o corneales. A nivel corneal se emplea principalmente en casos de defectos epiteliales persistes y perforaciones ${ }^{140}$ o en casos de lisis corneal generalizada con el fin de frenarla $\mathrm{y}$ favorecer la regeneración corneal $^{141}$. Su versatilidad permite dos formas de implantación: en primer lugar como injerto, orientando su cara estromal hacia abajo, cuyo principal objetivo es generar una barrera física y un microambiente gracias a los factores que aporta, y en segundo lugar, como recubrimiento orientando su cara estromal hacia arriba consiguiendo reducir la carga inflamatoria favoreciendo de este modo la epitelización y disminuyendo la cicatrización y la vascularización submembrana ${ }^{142}$.

-Determinados casos, con afectación grave del segmento anterior, pueden requerir intervenciones quirúrgicas más complejas. El trasplante de células madre del limbo ${ }^{143}$ y la queratoplastia penetrante (Fig.9) ${ }^{144}$ pueden ser dos alternativas a tener en cuenta, sin embargo, la queratoplastia penetrante constituye el último escalón terapéutico dado el mal pronóstico que tienen en estos pacientes con importante alteración limbar e insuficiencia lagrimal severa. Lo que se ha descrito con éxito han sido las queratoplastias tectónicas en casos de perforaciones corneales localizadas así como los trasplantes de membrana amniótica multicapa ${ }^{145}$.

- También debe de ser valorada la tarsorrafia ${ }^{146}$ que ayuda a reducir la exposición de la superficie ocular aunque disminuye el campo de visión periférico y 
pueden ser consideradas por algunos pacientes como poco estéticas al imposibilitar el uso de lentes de contacto o necesitar el empleo de gafas oclusivas.

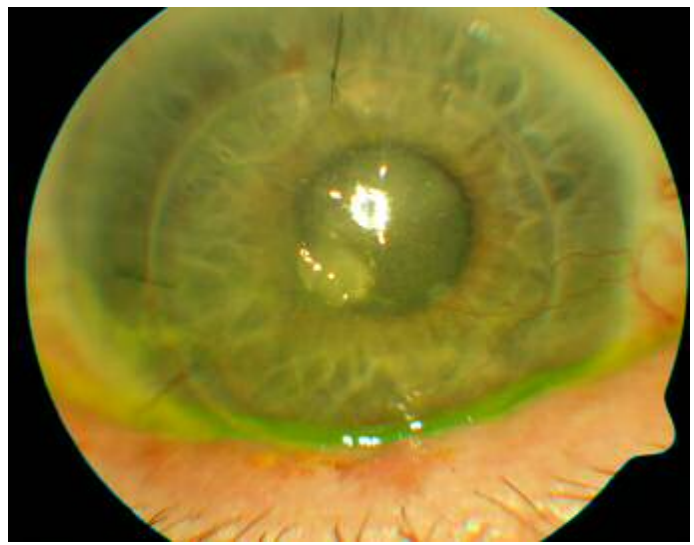

Fig.9. Queratoplastia penetrante con presencia de neovascularización corneal periférica incipiente a las 3 horas y queratitis filamentosa.

\subsubsection{Prevención de la evaporación lagrimal}

La inestabilidad de la película lagrimal característica de un síndrome de ojo seco evaporativo se puede observar cuando existe asociada una disfunción de las glándulas de Meibomio (DGM). La aplicación de calor seco mediante compresas al menos dos veces al día combinado con cuidados higiénicos del borde palpebral suelen ser suficientes en la mayoría de los casos.

- El uso de antibióticos de la familia de las tetraciclinas (doxiciclina, minociclina) o macrólidos (azitromicina) se puede asociar a las medidas anteriores en los casos más graves puesto que además ser un antibiótico tiene propiedades antiinflamatorias a través la inhibición de las metaloproteinasas y de la actividad de la IL-1.

\subsubsection{Tratamiento sistémico de la EICRo}

La inmunosupresión sistémica no se recomienda de entrada en aquellos pacientes con EICRo aislada por sus efectos adversos. Sin embargo, se ha observado

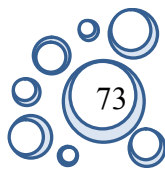


que la reducción de la dosis de los fármacos inmunosupresores o su retirada puede conducir a un empeoramiento de la EICRo. En casos de EICRo refractaria a tratamientos tópicos o EICRo grave asociada a otras manifestaciones sistémicas, se deberá valorar la instauración de inmunosupresión sistémica. En este sentido, se ha descrito una mejoría en los resultados del test de Schirmer en pacientes con EICR crónica en tratamiento con imatinib ${ }^{147}$. Entre los fármacos más empleados son la ciclosporina, el tacrólimus, los corticoides y el rituximab ${ }^{148}$.

- La fotoaféresis ha demostrado buenos resultados en los pacientes con EICR crónica mejorando la clínica de su afectación ocular ${ }^{149}$.

- Los ácidos grasos esenciales como el omega 3, deben de ser administrados con la dieta o a través de complejos vitamínicos disponibles en el mercado, puesto que inhiben la síntesis de mediadores de la inflamación y mejoran la clínica ${ }^{150}$. 


\section{CÉLULAS ESTROMALES MESENQUIMALES}

Las células estromales mesenquimales (CSM) son células multipotentes adultas con morfología fusiforme $\mathrm{y}$ de aspecto fibroblástico $\mathrm{y}$ con potencialidad para diferenciarse hacia diversos linajes celulares en diferentes estadios de maduración, como condrocitos, osteocitos y adipocitos entre otros. Las CSM son frecuentemente utilizadas en terapia celular y fueron descritas por primera vez por Friedenstein y colaboradores $^{151-154}$. Estas células se pueden aislar principalmente a partir de médula ósea (MO), sangre de cordón umbilical y tejido adiposo de donde se han logrado establecer cultivos que han permitido estudiar sus propiedades funcionales $\mathrm{y}$ fenotípicas.

\subsection{Caracterización y cultivo de las CSM}

La MO es la principal fuente de aislamiento de CSM, aunque se han aislado de tejido adiposo, páncreas, hígado, músculo esquelético, dermis, membrana sinovial, hueso trabecular ${ }^{155-158}$, sangre de cordón umbilical ${ }^{159}$, tejido pulmonar $^{160}$, pulpa dental y ligamento periodontal ${ }^{161}$.

Las CSM procedentes de MO humana se encuentran en una baja proporción en su fracción mononuclear, siendo su porcentaje inferior al $0.01 \%{ }^{153,154,162,163}$. La selección de la población mesenquimal se realiza mediante sucesivos pases en cultivo y las CSM derivadas de MO se suelen caracterizar en pase 3, donde la contaminación con células hematopoyéticas medulares es prácticamente inexistente. En cuanto a su inmunofenotipo esta población no posee un marcador específico, sino que comparte características fenotípicas con algunas células endoteliales, epiteliales y musculares, si bien el patrón de expresión empleado diversos marcadores es característico ${ }^{164-174}$. Dada la relevancia clínica de las CSM, la Sociedad Internacional de Terapia Celular en 2006

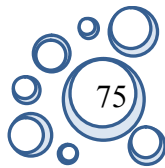


puso de manifiesto la necesidad de utilizar un método de identificación común y propuso tres criterios mínimos que toda célula que se defina como CSM debe cumplir y que se utilizan para la identificación de dichas células ${ }^{175}$.

- 1) Las CSM deben tener capacidad de adherencia al plástico cuando se mantienen en condiciones estándar de cultivo.

- 2) Deben expresar mediante citometría de flujo (Fig. 10) determinados marcadores (CD105, CD73 y CD90) y no expresar otros marcadores específicos de diversas líneas hematopoyéticas como CD45, CD14, CD11b, CD79 $\alpha$ o CD19 ni tampoco moléculas del complejo mayor de histocompatibilidad de clase 2 (HLA-DR).

- 3) Deben mostrar capacidad de diferenciarse in vitro hacia osteoblasto, adipocito y condroblasto.

\section{EXPRESIÓN POSITIVA}
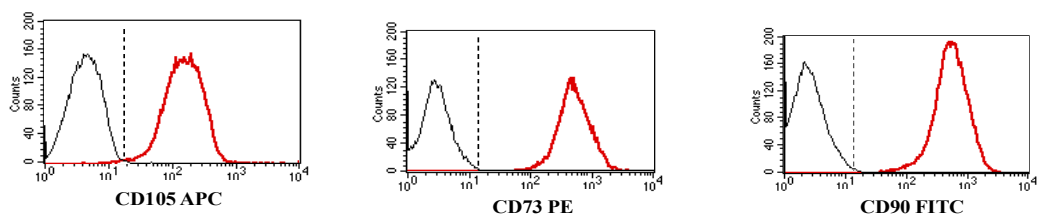

\section{EXPRESIÓN NEGATIVA}
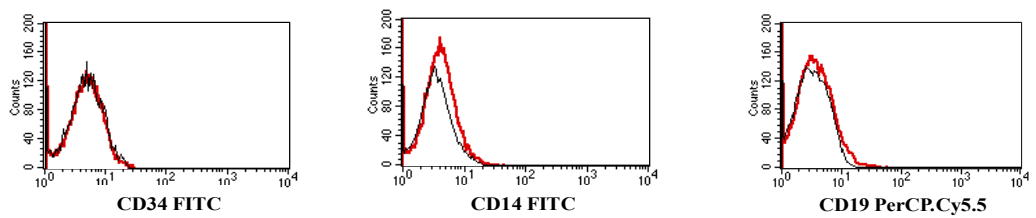

Fig. 10. Queratoplastia penetrante con presencia de neovascularización corneal periférica incipiente a las 3 horas y queratitis filamentosa.

\subsection{Potencial de diferenciación de las CSM}

Esta capacidad de diferenciación multilineal, convierte a las CSM en un tipo celular muy atractivo para el campo de la medicina regenerativa y de la ingeniería tisular. 
Existe numerosa bibliografía en la que se pone de manifiesto que las CSM pueden diferenciarse in vitro hacia células de distintos tejidos como tenocitos, miocitos esqueléticos, células del mesodermo e incluso, según algunos autores, del ectodermo y del endodermo, aunque esto es motivo de notable controversia ${ }^{153,176-180}$. Sin embargo, la Sociedad Internacional de Terapia Celular requiere al menos diferenciación a adipocito, osteoblasto y condrocito $^{181}$.

- Diferenciación a osteoblasto. La diferenciación osteogénica se detecta evaluando el aumento de la actividad de la fosfatasa alcalina y la aparición de depósitos de calcio, que se observan tras la tinción con NBT- BCIP o con rojo alizarina, respectivamente ${ }^{182}$.

- Diferenciación a adipocito. La diferenciación hacia adipocito se detecta por la aparición vacuolas lipídicas en el citoplasma que con el tiempo se van agrupando y llenando el citoplasma celular. Estos acúmulos de lípidos se ponen de manifiesto mediante la tinción con rojo al aceite (oil-red-O) ${ }^{181}$.

- Diferenciación a condorcito. La diferenciación condrogénica de las CSM se pone de manifiesto al demostrar en estas células los cambios morfológicos y la expresión de componentes de la matriz extracelular como colágenos tipo I, II, IX o $\operatorname{agrecano}^{183}$.

\subsection{Funcionalidad de las CSM}

Funcionalmente, las CSM de médula ósea debido a la gran variedad de citocinas que secretan tanto en estado de reposo como tras estimulación y a la gran cantidad de señales que reciben tanto inductivas como reguladoras colaboran en la formación del nicho hematopoyético de modo que proporciona el microambiente adecuado para la

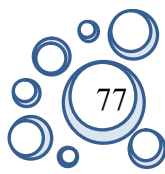


auto-renovación, proliferación y diferenciación de las propias CSM y otros progenitores hematopoyéticos. Pueden ser movilizadas y diferenciarse a distintas estirpes del tejido conectivo debido a diferentes vías de señalización. Estas señales pueden ser inducidas por daños traumatológicos, de inflamación, necrosis o tumores. Por tanto, la capacidad de las CSM para secretar distintos factores solubles puede alterar el microambiente y de este modo favorecer la reparación del daño tisular. Entre estos factores secretados por las CSM se incluyen TGF-1, IL-1, IL-1 $\beta$, IL- 3, IL-6, IL-7, IL-11, el factor de crecimiento de hepatocitos que actúan estimulando la proliferación y diferenciación de los progenitores endógenos que se encuentran en el tejido, disminuyendo la inflamación y la reacción inmune ${ }^{184}$. Las CSM poseen importantes propiedades inmunomoduladoras sobre LT, LB, células dendríticas y células $\mathrm{NK}^{175}$.

Además, las CSM producen numerosos factores de crecimiento, proteasas y citoquinas que juegan un importante papel en su capacidad inmunomoduladora y en su capacidad de migración ${ }^{185}$.

\subsection{Aplicaciones clínicas de las CSM en el contexto del}

\section{trasplante hematopoyético}

En los últimos años la Terapia Celular se perfila como una prometedora opción terapéutica en el tratamiento de diversas enfermedades ${ }^{186-193}$, y las CSM destacan entre los tipos celulares con mayor potencial debido a su fácil obtención y expansión in vitro, así como por sus propiedades inmunomoduladoras, antiinflamatorias, de multipotencialidad y de baja inmunogenicidad ${ }^{186-212}$.

La escasa inmunogenicidad de las CSM se debe a la limitada expresión de moléculas HLA, así como por la limitada o nula expresión de moléculas coestimuladoras. 
En cuanto a su capacidad para modular la respuesta inmune, se ha descrito que las CSM son capaces de inhibir la activación y proliferación de $\mathrm{LT}^{213-215}$. Esta capacidad inhibitoria es muy relevante en el tratamiento de la enfermedad injerto contra receptor $^{216}$.

Existe numerosa bibliografía en la que se emplean distintos modelos animales como en ensayos clínicos, en los que se describe cómo las CSM expandidas ex vivo han sido capaces de diferenciarse hacia distintas estirpes celulares de los tejidos dañados, reparando el daño y recuperando parcialmente la función normal ${ }^{217-222}$.

\subsubsection{Aplicación en citopenias y EICR aguda}

Las CSM se están evaluando fundamentalmente en el contexto del alo-TPH para la mejora del injerto hematopoyético y para el tratamiento de la EICR refractaria a esteroides:

- El fallo de injerto hematopoyético está presente hasta en un $20 \%$ de los casos. En muchos pacientes hematológicos sometidos a trasplante, el estroma puede presentar daño debido al acondicionamiento previo, lo que podría retrasar e incluso impedir el injerto de las células hematopoyéticas. Por ello, se están llevando a cabo ensayos con el fin de analizar la capacidad de las CSM para facilitar el injerto hematopoyético tras un trasplante, puesto que las CSM son las células estromales medulares ${ }^{223-227}$.

- El desarrollo de EICR agudo (EICRa) ocurre entre un 20-70\% de los casos.

La primera referencia en el empleo de CSM alógenicas en alo-TPH se publicó en 2004 en un paciente con EICR aguda grado IV refractario que respondió favorablemente a la terapia celular ${ }^{217}$. Posteriormente se han publicado resultados de distintos ensayos clínicos todos ellos con un pequeño número de pacientes y la mayor parte, ensayos en fase I o II. El ensayo con mayor número de pacientes es el que ha llevado a cabo el grupo $\mathrm{EBMT}^{228}$. En este trabajo se incluyeron un grupo heterogéneo

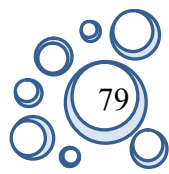


de pacientes con EICR aguda refractaria y que se trataron con una o más dosis de CSM alcanzando respuestas completas en el $70 \%$ de los casos y parciales en el $54 \%$. No se describieron efectos adversos. De forma global, se ha observado en los distintos ensayos en fase I y II realizados que aquellos pacientes que alcanzan una respuesta completa tienen una tasa de supervivencia global mayor.

A pesar de todo, quedan numerosas cuestiones por responder que afectan principalmente al método de expansión, al momento de administración, al número de dosis adecuado y su intervalo de administración, entre otros.

La experiencia en la EICR crónica es menor pero también ha demostrado ser una terapia segura y eficaz ${ }^{211}$ aunque el porcentaje de respuestas completas es inferior ${ }^{229}$.

Finalmente, en cuanto al papel de las CSM en la prevención de la EICR aguda existe poca información y los resultados son poco específicos ${ }^{230}$.

A pesar de todos estos resultados, diversos grupos de investigación se han propuesto desarrollar estrategias de manipulación celular para conseguir CSM con mayor potencial terapéutico estimulando sus propiedades inmunorreguladoras y favoreciendo los mecanismos de anidamiento.

\subsubsection{Reparación de las CSM en un modelo de ojo seco secundario a EICR}

La investigación en la búsqueda de nuevas estrategias terapéuticas que puedan aminorar la sintomatología e incrementar la calidad de vida de los pacientes con EICRo, resulta absolutamente prioritaria. Por este motivo, uno de las primeros objetivos de nuestro grupo de investigación fue la generación de un modelo murino de EICRo. En un primer trabajo, Lorenzo y cols., describieron las características histopatológicas que involucran córnea y limbo y que constituyen la base de la fisiopatología de la enfermedad a nivel ocular. Este modelo permite evaluar futuras estrategias terapéuticas para el tratamiento de la EICRo antes de su uso en un entorno clínico $^{224}$. 
Posteriormente, nuestro grupo de investigación ha puesto de manifiesto que CSM derivadas de MO transducidas con lentivirus que expresan GFP (Green fluorescence protein) y LUC2 (luciferasa), son capaces de migrar y de diferenciarse en tejido de la córnea después de ser administradas mediante inyección subconjuntival en el ojo de ratones $\mathrm{BALB} / \mathrm{c}$ a los que se les generó $\mathrm{EICRo}^{224}$. Tras el transplante, las hCSM GFP+ adquieren características morfológicas de células epiteliales, estromales y células endoteliales. Aparecen en diferentes capas y con diferentes morfologías dependiendo de su posición dentro de la córnea. Además, estas células presentan propiedades ultraestructurales, tales como haces de filamentos intermedios, interdigitaciones y desmosomas junto a células GFP negativas murinas, lo que confirma su diferenciación en tejidos de la córnea. En los ratones en los que se verificó la alteración de la superficie ocular secundaria a EICR una vez tratados, tanto el examen macroscópico como histopatológico mostraron una disminución de la sintomatología de la EICR en el ojo tratado, mientras que el ojo no tratado (no se inyectaron CSM) presentó las alteraciones típicas de la EICRo. Confirmamos en este estudio que las CSM inducen su efecto terapéutico al menos en parte por la diferenciación y regeneración de los tejidos dañados en el receptor. Estos resultados proporcionan la evidencia experimental de que las CSM pueden representan un potencial tratamiento celular con el objetivo de atenuar la EICRo. 


\section{IMPORTANCIA DE LA VÍA DE ADMINISTRACIÓN EN}

\section{EL TRATAMIENTO DE LAS ENFERMEDADES}

\section{OCULARES Y EN TERAPIA CELULAR}

\subsection{Vías de administración oftalmológica}

- Vía sistémica: El fármaco debe de atravesar una serie de barreras (hematoacuosa y hematorretinianas interna y externa) para alcanzar el interior del ojo. Las dos últimas son prácticamente impermeables a todas las sustancias en condiciones normales. En circunstancias libres de patología, se puede facilitar la penetración de los fármacos a las estructuras oculares disminuyendo su tamaño molecular y su unión a las proteínas circulantes o logrando un aumento en la solubilidad de los lípidos. También determinados procesos como la inflamación aumentan la permeabilidad de los tejidos $^{231}$.

- Vía tópica: Se caracteriza por su fácil aplicación y por lograr concentraciones elevadas en la superficie ocular. Entre las estrategias que se emplean para incrementar su absorción se encuentran: la adición de sustancias tensoactivas, favorecer la oclusión de los puntos lagrimales y palpebral tras la administración del fármaco, aumentar la frecuencia de las gotas y la solubilidad lipídica del fármaco. Entre los principales inconvenientes de esta vía destacan la limitada cantidad que entran en los fondos de saco conjuntivales y que solo un $1 \%$ de la dosis administrada llega a atravesar la barrera corneal alcanzando el segmento anterior siendo escasa su penetración en los tejidos del polo posterior. Además, pueden ejercer algún efecto tóxico debido a algunas reacciones de hipersensibilidad o efectos directos sobre la piel periocular, conjuntiva o la córnea. 
- Vía subconjuntival/ subtenon: La vía subconjuntival se prioriza cuando se requiere una alta concentración intraocular de antibióticos, anestésicos o corticoides dado que se evita el epitelio conjuntival. Un fármaco inyectado mediante punción conjuntival alcanza el espacio subconjuntival que por su característica laxitud permite albergar un volumen considerable de fármaco, el cual posteriormente puede ser reabsorbido por los tejidos adyacentes de forma progresiva. De esta forma permite obtener concentraciones intraoculares mejores y un tiempo de actuación más prolongado que los que se consiguen por vía tópica. El principal inconveniente son las complicaciones que pueden derivar de la técnica ${ }^{231}$.

-Vía retrobulbar/peribulbar: Se emplea en anestesia fundamentalmente.

- Vía intracamerular: La sustancia se introduce en la cámara anterior. Suele reservarse a la administración de fármacos en la cirugía.

- Vía intravítrea: Se introduce en el interior del vítreo mediante una inyección en pars plana. Asegura concentraciones terapéuticas mantenidas en los tejidos del segmento posterior ${ }^{231}$.

\subsection{Vías de administración de la terapia celular}

Hasta el momento, las vías de administración de las CSM en el ámbito clínico son la local o inyección directa y la administración por infusión sistémica. Para hacer una infusión sistémica eficaz se requiere un mayor volumen de CSM en comparación con las que se necesitan en una administración local. Este objetivo se puede lograr mediante su expansión in vitro.

El primer obstáculo que se encuentran las CSM tras su administración por vía intravenosa es el lecho capilar pulmonar. El tamaño de las CSM en suspensión es de alrededor de $30 \mu \mathrm{m}^{237}$, aunque este varia en función de la osmolaridad del medio de cultivo, el número de pases, la densidad celular durante la siembra así como las

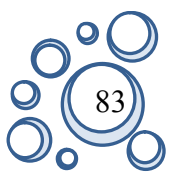


condiciones de cultivo. Su gran tamaño, contrasta con el de las células hematopoyéticas que son de menor diámetro $(4-12 \mu \mathrm{m}){ }^{238}$. Existen evidencias en distintos trabajos, que la acumulación de CSM a nivel pulmonar es el factor principal que condiciona su biodistribución y la molécula responsable de estos fenómenos parece ser la VLA4/VCAM1.

Se han desarrollado diversos estudios comparativos entre la administración intraarterial y la intravenosa $\mathrm{s}^{239,240}$ los cuales han demostrado una mayor asociación entre la administración intravenosa y la retención de las CSM en los pulmones y la administración intraarterial y una mayor acumulación de las células en los tejidos diana. Aunque se precisan desarrollar más estudios en este campo, en la actualidad se puede afirmar que la vía intraarterial es más efectiva al evitar la acumulación de las células a nivel pulmonar de modo que se puede mejorar la biodistribución y biodisponibilidad de las CSM trasplantadas alcanzando aquellos tejidos que son clínicamente relevantes y sobre los cuales deben de ejercer su efecto terapéutico.

Se han descrito la existencia de interacciones entre las CSM y los distintos tipos de células inmunes, lo cual implica que tienen capacidad de responder a las señales emitidas por las distintas células que constituyen el sistema inmune. Es probable que las señales de inflamación y reparación tisular influyan en las respuestas de las CSM in vivo incluyendo su biodistribución.

No hay estudios comparativos de la administración local por vía subconjuntival de CSM con otras vías de administración convencionales. El potencial de la administración subconjuntival se explora en el presente trabajo. 


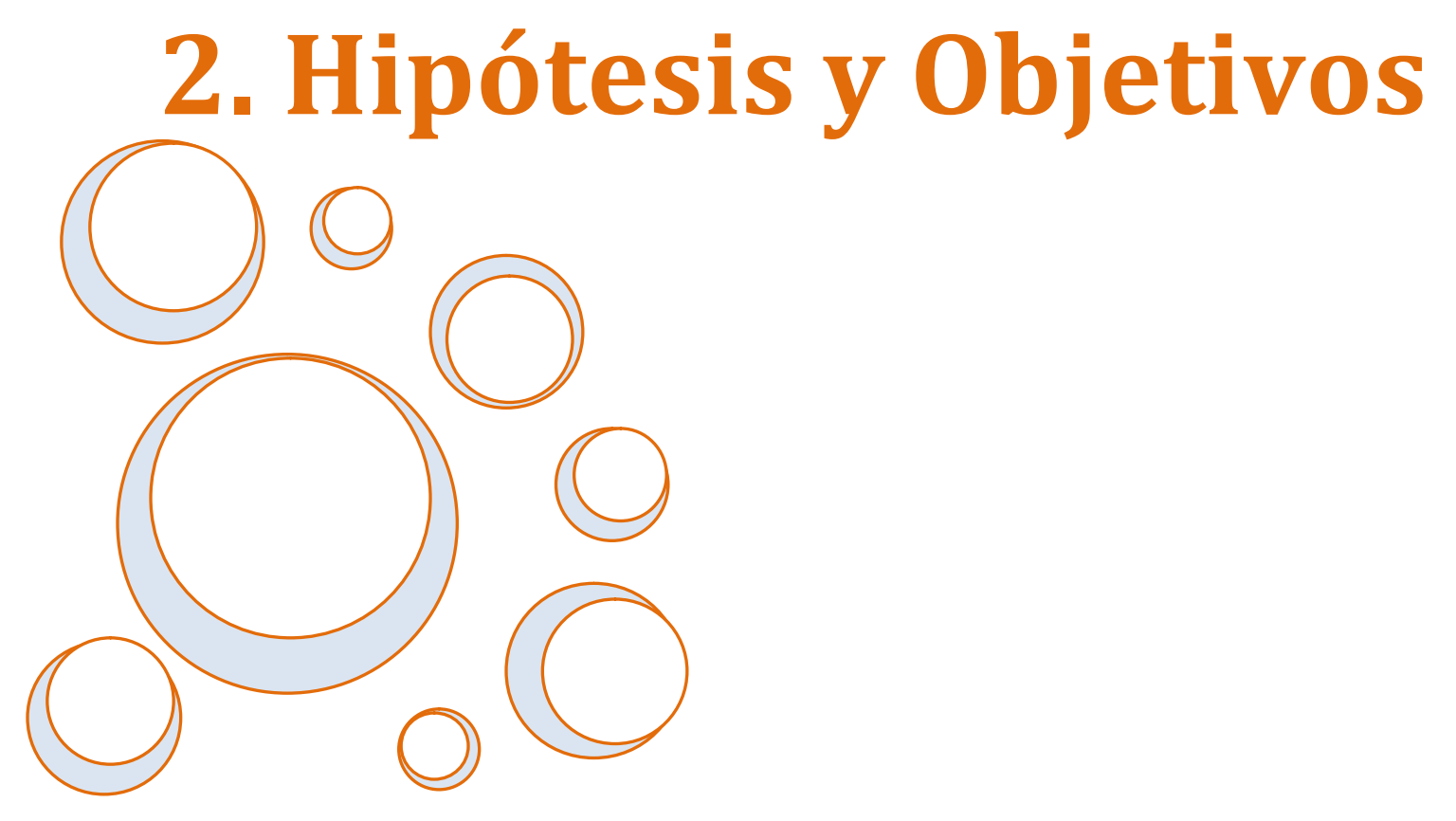





\section{HIPÓTESIS Y OBJETIVOS}

Los modelos animales de EICRo se han basado en el análisis histológico del tejido afectado, que es fundamentalmente el segmento anterior y la superficie ocular. Pero teniendo en cuenta que una de las características de esta complicación es la infiltración por células $\mathrm{T}$ alogénicas y que las manifestaciones fundamentales son las del ojo seco, nos planteamos como hipótesis por una parte que el análisis de la evolución de la infiltración celular así como la determinación de parámetros clínicos en el modelo animal de EICRo podría implementarlo y así aproximarlo más a lo que ocurre en los pacientes con EICRo, y por otra parte que la administración local de las hCSM podría ser potencialmente útil en el tratamiento de la EICRo, especialmente si su administración es mediante inyección subconjuntival, pues esta vía permitirá la persistencia celular a largo plazo y ejercer su efecto de forma continuada.

Con esta doble hipótesis nos planteamos los siguientes objetivos:

$1^{\mathrm{o}}$.- Generar y validar un modelo murino de EICRo con ojo seco que presente afectación a nivel palpebral y glandular, que evalúe de forma multiparamétrica los cambios de parámetros macroscópicos, histológicos y funcionales del modelo murino de ojo seco generado, analizando en detalle las alteraciones que definen el síndrome de ojo seco como son la medida de producción de lágrima y la osmolaridad de la película lagrimal.

$2^{\circ}$.- Evaluar mediante técnicas de bioluminiscencia e inmunohistoquímica, la persistencia a largo plazo de las hCSM administradas por vía subconjuntival en el ojo derecho de ratones BALB/c a los que previamente se les ha generado EICRo.

$3^{\circ}$.- Analizar el efecto terapéutico de la administración subconjuntival de hCSM evaluando la mejoría en la infiltración linfocitaria $\mathrm{T}$ alogénica, los cambios histológicos $\mathrm{y}$ en el volumen $\mathrm{y}$ osmolaridad lagrimal tras el tratamiento celular. 



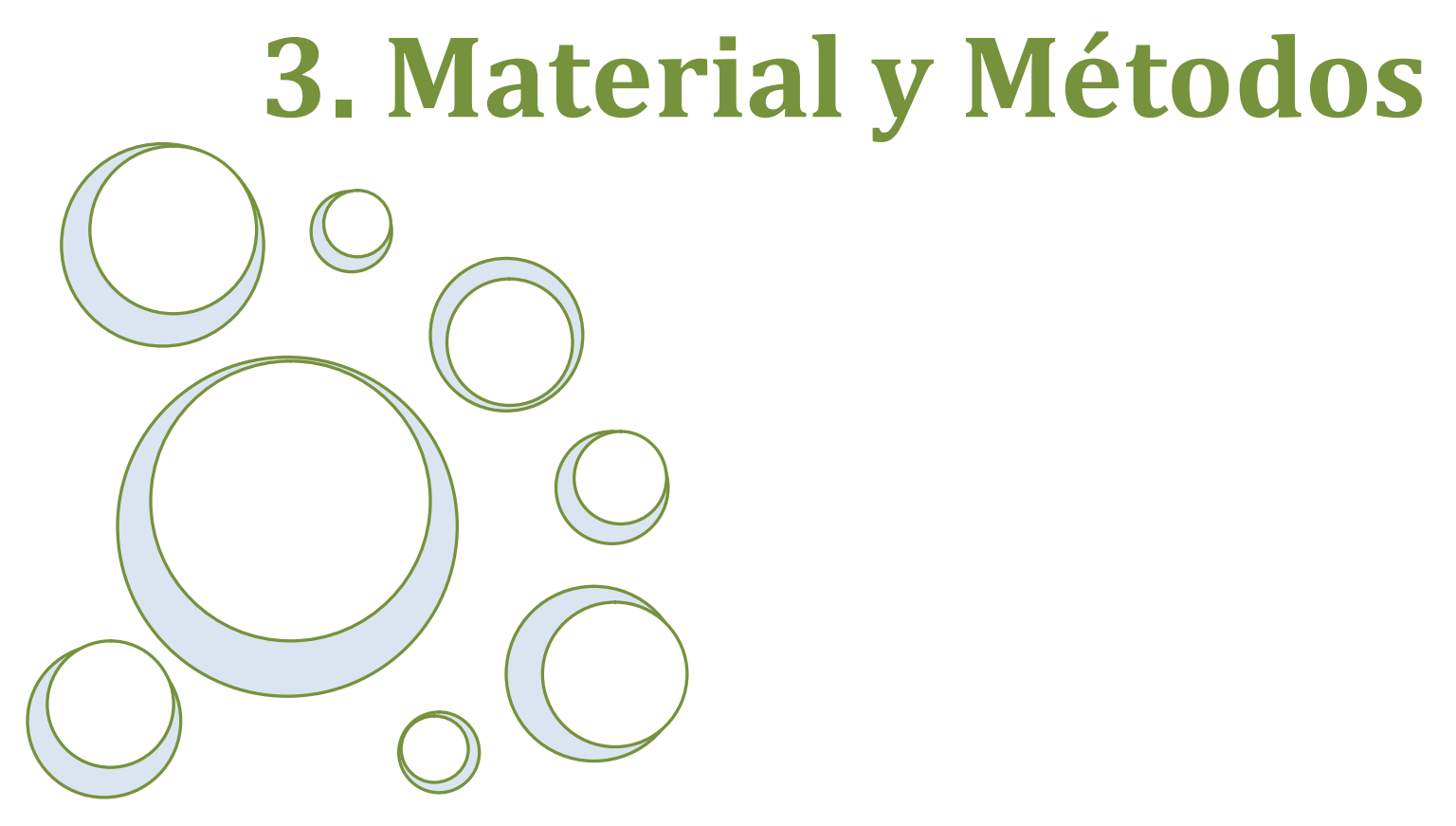





\subsection{MATERIAL}

\subsubsection{Animales de experimentación}

Los experimentos vinculados con la investigación animal se llevaron a cabo en el Servicio de Experimentación Animal de la Universidad de Salamanca, en las instalaciones del Edificio Departamental de la Universidad de Salamanca.

Se utilizaron las siguientes cepas de ratón: hembras BALB/c (H2d) y machos C57BL/6 (H2b). Todos los ratones se adquirieron en Charles River Laboratory (France).

Los protocolos de mantenimiento, manipulación y sacrificio de los animales cumplieron las directrices del Consejo de las Comunidades Europeas (86/609/EEC y 2003/65/EC) y de la legislación española (RD 1201/2005 de 10 de octubre, BOE de 21 de octubre de 2005) vigentes para el uso y cuidado de animales de experimentación y se llevaron a cabo bajo la supervisión del Servicio de Experimentación Animal de la Universidad de Salamanca.

\subsubsection{Obtención de células estromales mesenquimales para cultivo}

Para llevar a cabo tanto los estudios in vitro e in vivo, se emplearon muestras procedentes de MO de donantes sanos. Las muestras empleadas se obtuvieron tras el correspondiente consentimiento informado de acuerdo con la Declaración de Helsinki. Los procedimientos empleados siguen las directrices establecidas por el Comité Ético del Hospital Universitario de Salamanca. El procesamiento de las muestras se realizó en el Laboratorio de Cultivos y Terapia Celular del Servicio de Hematología en el Hospital Universitario de Salamanca bajo estrictas condiciones de esterilidad. 


\subsubsection{Material no biológico}

Los materiales necesarios para llevar a cabo los experimentos fueron los siguientes:

-Para desarrollar el modelo murino de trasplante y generación de EICH se utilizaron: Suero fisiológico 0,9\% de Baxter S.L. (Ribarroja del Turia, Valencia), medio de cultivo RPMI, PBS y antibióticos (penicilina y estreptomicina) de GIBCO BRLInvitrogen (Grand Island, NY, EEUU), placas de petri estériles de $100 \mathrm{~mm}$ de Soria Genlab, S.A., filtros con tamaño de poro de $40 \mu \mathrm{m}$ de Becton-Dickinson, Biosciencie, San José, CA, agujas de 25G (0,5mm x 16mm) de BD MicrolanceTM (BD Drogheda, Irland), jeringas de $1 \mathrm{ml}$ de BD Plastipak (BD Madrid) y agujas de insulina de $27 \mathrm{G}(0.4$ $\mathrm{x} 12 \mathrm{~mm})$ de TERUMO.

- Para el acondicionamiento pre-trasplante de los ratones se empleó un irradiador de muestras biológicas Gammacell 1000 con una fuente de Cesio de 137 situado en el Animalario del Edificio Departamental de la Universidad de Salamanca.

- Los estudios de citometría se llevaron a cabo en un citómetro FACS Calibur (Becton Dickinson Bioscience San Jose, CA, EEUU) y empleamos el programa de adquisición CellQuestR de (Becton Dickinson Bioscience, San José, CA, EEUU) y las muestras se analizaron mediante el programa Infinicyt1.1 (Cytognos S.L. Salamanca).

- La separación de las CMN procedentes de MO humana se hizo por centrifugación mediante gradiente de densidad con Ficoll (Ficoll-Paque, densidad: 1.077k, GE Healthcare BioSciences, Buckinghampshire, UK). La MO se diluyo en Medio Hanks (Hanks Salt Solution, Gibco ${ }^{\circledR}$, Invitrogen ${ }^{\mathrm{TM}}$ ).

- Para la realización de los cultivos y la expansión de las CSM se empleó: el medio Dulbecco's modified Eagle's medium-low glucose (DMEM) (GIBCO ${ }^{\text {, }}$ Invitrogen ${ }^{\mathrm{TM}}$ Corporation, Paisely, UK) suplementado con Suero Bovino Fetal al 10\% 
(SBF: BioWhittakerR Lonza, Verviers, Belgium) y Penicilina 105U/ml/Estreptomicina $105 \mu \mathrm{g} / \mathrm{ml}$ (Gibco, Invitrogen, Paisely, UK) al 1\%. El medio Hanks's Balanced Salt Solution $1 \mathrm{X}$ con $0.35 \mathrm{~g} / \mathrm{L}$ NaHCO3 (HBSS) de Sigma-Aldrich (St. Louis, MO, USA). La heparina libre de aditivos 5000U/ml procede de Biochrom AG (Berlin, Alemania). El dimetil sulfoxido (DMSO) es de Sigma-Aldrich. El PBS estéril (GIBCO ${ }^{\text {, }}$ Invitrogen ${ }^{\mathrm{TM}}$ Corporation, Paisely, UK). La tripsinización de los cultivos se llevó a cabo con Trypsin-EDTA .05\% 1X (GIBCO®, Invitrogen ${ }^{\mathrm{TM}}$ Corporation, Paisely, UK).

- La Diferenciación de las CSM se llevó a cabo con medio de diferenciación osteogénica (NH Osteodiff Medium, Miltenyi Biotec, Bergisch Gladbach, Germany), medio de diferenciación adipogénica (NH Adipodiff Medium, Miltenyi Biotec, Bergisch Gladbach, Germany), medio de diferenciación condrocítica (NH Chondrodiff Medium, Miltenyi Biotec, Bergisch Gladbach, Germany), etanol (Merck KGaA, Darmstadt, Germany), NBT/BCIP solution (Nitroblue tetrazolium chloride/5-bromo-4chloro-3 indolylphosphate, Roche, Basel, Switzerland), Oil-Red-O solution (Certistain ${ }^{\circledR}$ Merck KGaA, Darmstadt, Germany), isopropanol (Merck KGaA, Darmstadt, Germany), paraformaldehído (Panreac, Barcelona, España), Hematoxilina (Merck KGaA, Darmstadt, Germany), tubos cónicos de 15ml (Corning Incorporated, Corning, NY, USA).

- Para el procesamiento histológico de las muestras obtenidas se empleó el tampón salino Dulbecco's Phosphate Buffer Saline $1 \mathrm{X}$ (PBS) de GIBCO ${ }^{\circledR}$ InvitrogenTM (Paisely, UK), el medio OCT ${ }^{\circledR}$ Tissue-Tek y se cortaron en el criostato MICROM HM 505 N. Para el procesamiento de las muestras en parafina: Primeramente se fijaron con formaldehido a 10\% (Sigma-Aldrich, USA), se deshidrataron con alcoholes y xilol (Panreac, Barcelona, España) y finalmente fueron incluidas en parafina (Leica ASP 6025). Las muestras se cortaron con el micrótomo Leica RM 2235 (Leica 
Misrosystems, Alemania) en secciones de $4 \mu \mathrm{m}$. Las muestra cortadas se montaron en portas Leica bond plus.

La tinción histológica con hematoxilina (Merck Millipore, Darmstadt, Alemania)/eosina (Merck Millipore, Darmstadt, Alemania) se llevó a cabo en el teñidor (Thermo Scientific Varistain Gemini).

La reacción de PAS (Periodic Acid Schiff) se basa en la oxidación de los tejidos con ácido peryodico (Merck Millipore, Darmstadt, Alemania) y posteriormente, la muestra se trata con el reactivo de Schiff (Merck Millipore, Darmstadt, Alemania) dando una coloración rojo-púrpura característica.

La determinación de la caspasa 3 se realizó mediante el sistema automatizado BOND-MAX ${ }^{\circledR}$ (Leica Biosystems, Melbourne, Australia). Se empleó el anticuerpo primario policlonal de conejo anti Caspasa 3 (Cell Signaling Technology, MA, USA) y se reveló utilizando el Novolink Polymer Detection System ${ }^{\circledR}$ (Leica Microsistemas, Barcelona, España).

Las muestras de citología de impresión se recogieron en tiras de papel de filtro de $5 \times 3 \mathrm{~mm}$ de tamaño, se fijaron en una Solución de fijación comercial (Exeter Clinical Laboratory, Exeter, United Kingdom), procediéndose posteriormente a su tinción con PAS-hematoxilina.

Todas las imágenes de microscopía óptica de este trabajo fueron obtenidas con el Microscopio óptico Leica DMD 108 del Servicio de Anatomía Patológica del Complejo Asistencial Universitario de Salamanca.

- Para los estudios de inmunohistoquímica, los anticuerpos empleados para la identificación de las CSM humanas fueron: anti-GFP (AB-5450, Abcam) y antimitocondria humana (MAB-1273, Millipore). Las imágenes de microscopia confocal fueron obtenidas con el Microscopio Laser Confocal Leica SP5. 
- El seguimiento celular de las CSM se hizo mediante estudios de bioluminiscencia in vivo. Los ratones se sedaron con isofluorano (Forane, Abbot Laboratories, Madrid) y se les inyectó por vía intraperitoneal, una solución de luciferina (Promega, Madison, WI, USA). 
-Los anticuerpos monoclonales, empleados para análisis por citometría de flujo fueron:

Tabla 6. Relación de los anticuerpos monoclonales

\begin{tabular}{|c|c|c|c|}
\hline Anticuerpo & Fluorocromo & Isotipo & Procedencia \\
\hline CD14 & $\mathrm{PE}$ & MouseIgG $_{2 \mathrm{a}, \kappa}$ & Cytognos \\
\hline CD19 & PerCP/Cy5.5 & MouseIgG $\mathrm{I}_{1, \kappa}$ & BD Bioscience \\
\hline CD34 & FITC & MouseIgG $_{1, \kappa}$ & BD Bioscience \\
\hline CD44 & FITC & MouseIgG $_{1, \kappa}$ & BD Bioscience \\
\hline CD45 & PerCP/Cy5.5 & MouseIgG $\mathrm{I}_{1, \kappa}$ & BD Bioscience \\
\hline CD73 & $\mathrm{PE}$ & MouseIgG $_{1, \kappa}$ & BD Pharmingen \\
\hline CD90 & FITC & MouseIgG $\mathrm{I}_{1, \kappa}$ & BD Pharmingen \\
\hline CD105 & APC & MouseIgG $\mathrm{I}_{1, \kappa}$ & R\&D System \\
\hline CD166 & $\mathrm{PE}$ & MouseIgG $\mathrm{I}_{1, \kappa}$ & BD Pharmingen \\
\hline HLA-DR & PerCP & MouseIgG $_{2 \mathrm{a}, \kappa}$ & BD Bioscience \\
\hline $\mathrm{H} 2 \mathrm{Db}$ & FITC & MouseIgG $_{2 b, \kappa}$ & BD Pharmingen \\
\hline H2Dd & PE & MouseIgG $_{2 \mathrm{a}, \kappa}$ & BD Pharmingen \\
\hline CD3 & PerCP/Cy5.5 & MouseIgG $_{2 b, \kappa}$ & BD Pharmingen \\
\hline CD4 & APC & MouseIgG $_{2 b, \kappa}$ & Inmunostep \\
\hline CD8 & Percp/Cy5.5 & MouseIgG $\mathrm{I}_{2 \mathrm{~b}, \kappa}$ & Inmunostep \\
\hline CD45 & Alexa Fluor & MouseIgG $_{2 b, \kappa}$ & BD Pharmingen \\
\hline
\end{tabular}




\subsection{MÉTODOS}

\subsubsection{Modelo murino de generación de EICRo}

Para la generación de un modelo de EICRo murino empleamos como donantes, ratones machos de entre 8 y 10 semanas de edad de la cepa C57BL/6 con haplotipo $\mathrm{H} 2 \mathrm{~b}$ y como receptores ratones hembras de entre 8 y 10 semanas de la cepa BALB/c con haplotipo H2d (Fig.11). Estas dos cepas comparten el antígeno de clase I (H2) y difieren en antígenos miHAs ( $\mathrm{H} 2 \mathrm{~d}$ versus $\mathrm{H} 2 \mathrm{~b}$ ). Con el modelo de trasplante $\mathrm{C} 57 \mathrm{BL} / 6$ en BALB/c se consigue un modelo de incompatibilidad HLA para generar una EICR comparable a la que sucede en humanos. Mediante citometría de flujo, es posible la identificación de las células procedentes tanto del donante como del receptor en los ratones trasplantados, debido a la existencia de anticuerpos monoclonales específicos para cada cepa de ratón. De este modo se puede conocer el quimerismo a diferentes tiempos post-trasplante. Los Antígenos Menores de Histocompatibilidad (MiHAs) son péptidos propios polimórficos capaces de inducir una respuesta por células $\mathrm{T}$ y disparar una enfermedad de injerto-contra-huésped cuando son presentados por las MHC I y MHC II, los MiHAs son por tanto restringidos por el $\mathrm{MHC}^{224}$.

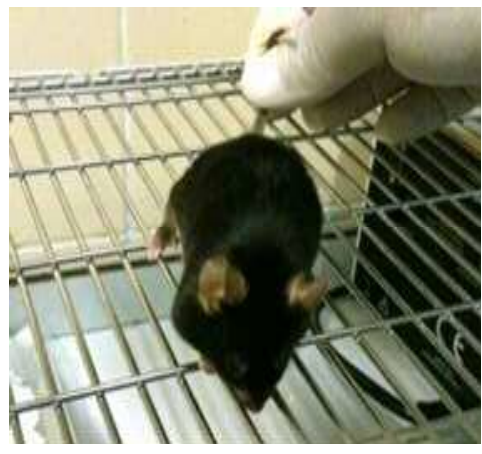

C57BL6

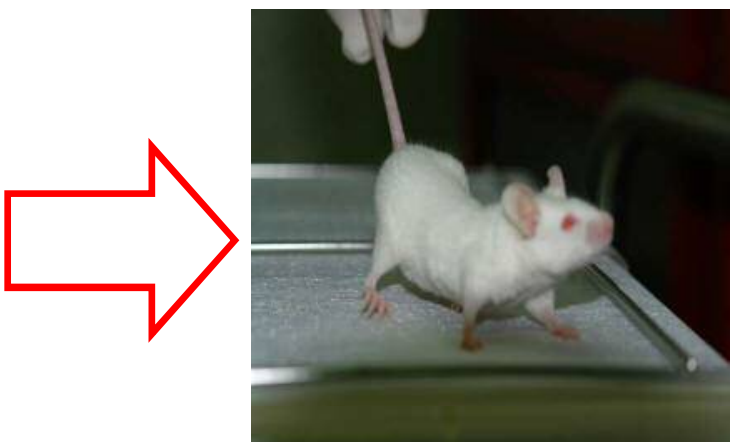

BALB/c

Fig. 11. Modelo murino del trasplante de MO y generación de EICR: C57BL/6 $\rightarrow$ BALB/C

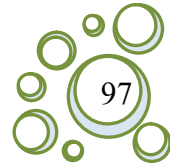




\subsubsection{Células empleadas en el trasplante}

Para la generación del modelo murino EICRo en los ratones de la cepa BALB/c se llevó a cabo un trasplante alogénico murino de células de MO y bazo procedentes de ratones donantes $\mathrm{C} 57 \mathrm{BL} / 6$ en ratones receptores BALB/c (Fig. 12).

La MO se obtuvo inyectando medio de cultivo RPMI a presión por el canal medular de los fémures y las tibias de los ratones donantes. Para ello, se emplearon agujas de $25 \mathrm{G}(0,5 \times 16 \mathrm{~mm})$. La solución celular resultante se hizo pasar a través de filtros de $40 \mu \mathrm{m}$ de poro y después su centrifugación se contaron mediante una cámara celular de Neubauer.

Las células procedentes del bazo del ratón donante (esplenocitos) tienen un elevado porcentaje de LT maduros lo que le confiere un papel esencial en la generación de EICR en el ratón receptor. El bazo se disgregó mecánicamente entre dos portas esmerilados. Al igual que las células procedentes de MO, la solución de esplenocitos obtenida se hizo pasar a través de un filtro de $40 \mu \mathrm{m}$ de poro y tras el lavado de las células se determinó el número de células disponibles.

\subsubsection{Irradiación}

El proceso de irradiación de los ratones $\mathrm{BALB} / \mathrm{c}$ se llevó a cabo empleando una fuente de Cesio 137, mediante un irradiador de muestras biológicas Gammacell 1000 que consta de dos partes:

-Un contenedor fijo de la fuente radiactiva encapsulada en plomo

-Un rotor que contiene un canister donde se introducen los ratones y cuya base rotatoria permite una exposición homogénea de la muestra a la fuente.

Los ratones receptores se sometieron a una irradiaron corporal letal de 850cGy dividida en dos fracciones de 425cGy separadas por 4 horas (Fig. 12). 


\section{GENERACIÓN DE EICH \\ TRASPLANTE DE MO y ESPLENOCITOS}
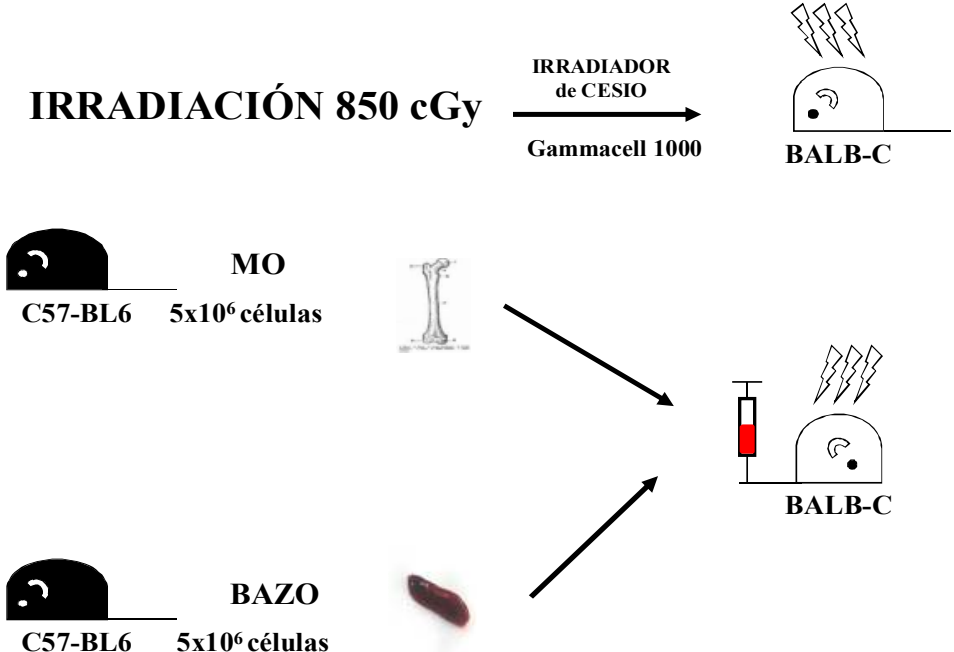

Fig. 12. Esquema del modelo murino de trasplante y generación de EICHo. Modelo C57BL/6 en BALB/c.

\subsubsection{Trasplante}

Dos horas después de la segunda irradiación procedimos al trasplante de los ratones receptores. El ratón receptor se inmoviliza en una jaula donde con una bombilla infrarroja de calor conseguimos dilatar las venas laterales de su cola (Fig. 13). Inmediatamente después administramos con una jeringa TERUMO MYJECTOR de $0,5 \mathrm{~mL}$ y una aguja montada de $27 \times 1 / 2 "-0,4 \times 12 \mathrm{~mm}$ una infusión que contiene $5 \times 10^{6}$ células de MO y 5 x $10^{6}$ esplenocitos de ratones donadores en un volumen de $300 \mu 1$ de RPMI.

\section{Canalización de las venas laterales de la cola del ratón}

BALB/c para la administración del trasplante

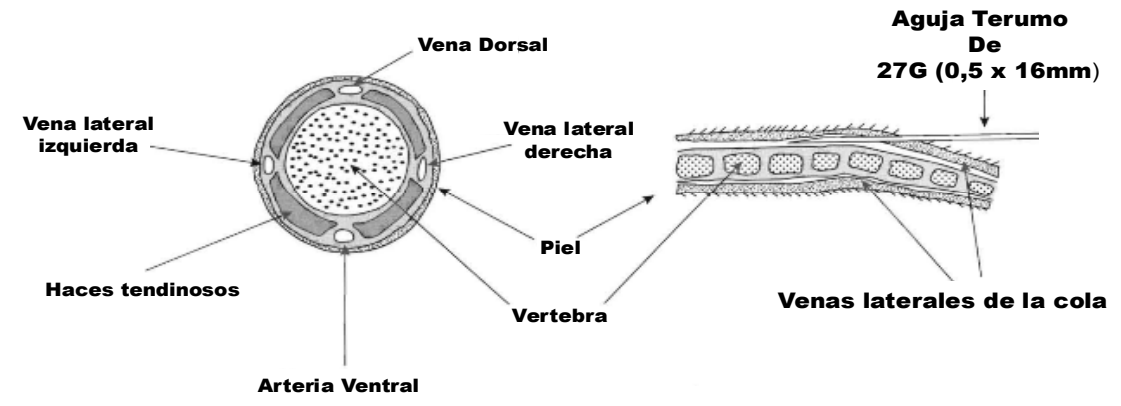

Fig. 13. Anatomía de la vía de administración endovenosa del trasplante murino. 


\subsubsection{Evolución del quimerismo post-trasplante mediante citometría de flujo}

Con objeto de analizar el quimerismo post-trasplante en distintas localizaciones, se sacrificaron ratones a diferentes días post-trasplante y se analizó mediante citometría de flujo la sangre periférica (SP), la MO y el bazo.

El panel utilizado fue el siguiente (Fig. 14):

\section{- H2Db-FITC/H2Dd-PE/CD3-PerCP-Cy5.5/CD45-Alexafluor}

Las células procedentes de SP, MO y bazo de ratones trasplantados BALB/c se hicieron pasar a través de filtros de $40 \mu \mathrm{m}$ de poro, se lavaron y resuspendieron en $100 \mu 1$ de PBS. Se añadieron la combinación de anticuerpos indicada en tubos de citometría y se incubaron durante 15 minutos, a temperatura ambiente y en oscuridad. Posteriormente, se añadieron $2 \mathrm{ml}$ de solución de lisis FACS a cada tubo y tras resuspender las células se incubaron durante 6 minutos. Seguidamente, las células se centrifugaron a $1200 \mathrm{rpm}$ durante 10 minutos $\mathrm{y}$, tras retirar el sobrenadante con pipetas Pasteur se lavaron las células con PBS. Después de una segunda centrifugación a 1200 rpm durante 10 minutos se retiró el sobrenadante y las células marcadas se resuspendieron en $200 \mu 1$ de PBS. Finalmente los tubos se adquirieron en un citómetro de flujo modelo FACSCalibur, utilizando el programa informático CellQuest ${ }^{\circledR}$. Para el análisis de los archivos empleamos el programa Infinicyt (Cytognos S.L. Salamanca, España). 


\section{Quimerismo en SP de LT trancurridos 7D del trasplante C57BL/6 en BALB/c}
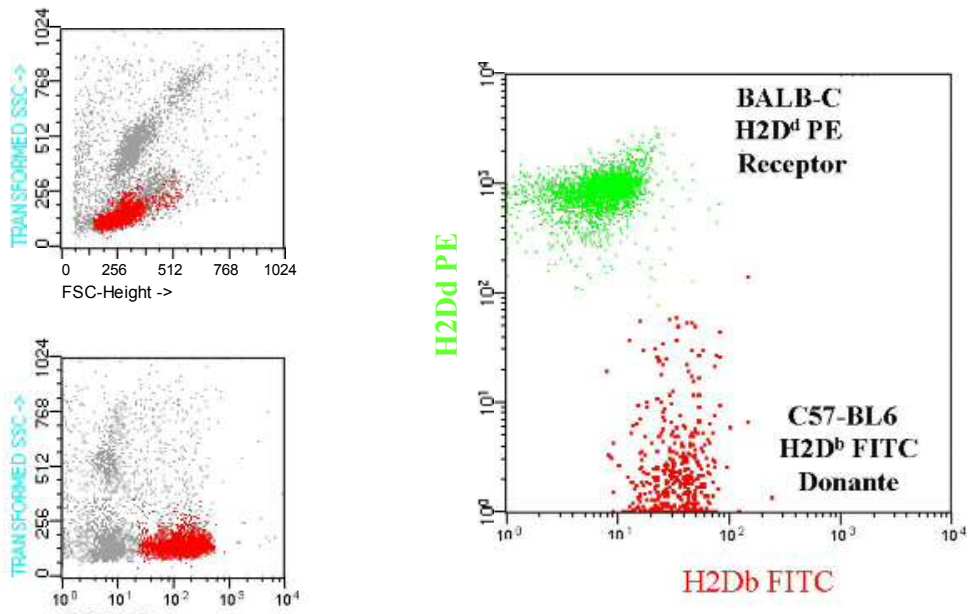

Fig. 14. Linfocitos $\mathrm{T}$ en $\mathrm{SP}$ de un ratón $\mathrm{BALB} / \mathrm{c}$ trancurridos $7 \mathrm{~d}$ de una irradiación con 850 cGy y un trasplante con $5 \times 10^{6}$ células procedentes de $\mathrm{MO}$ y $5 \times 10^{6}$ esplenocitos procedentes de un ratón C57BL/6. En rojo los LT procedentes del ratón donante C57BL/6 $\mathrm{y}$ en verde los $\mathrm{LT}$ pertenecientes al ratón receptor $\mathrm{BALB} / \mathrm{c}$. 


\subsubsection{Obtención, aislamiento, expansión y transducción de CSM}

El aislamiento, expansión y transducción de las CSM humanas se hizo a partir de muestras procedentes de medula ósea (MO).

\subsubsection{Obtención de la MO}

La extracción de la MO se realizó mediante punción en la espina ilíaca posterosuperior de donantes sanos bajo anestesia general. Se emplearon tubos estériles (Venoject; Terumo ${ }^{\circledR}$ ) a los que se adicionó heparina libre de aditivos (Heparina 5000U/ml; Seromed Biochrom KG), reconstituida con agua destilada Vitulia esteril (Laboratorios ERN, SA). Todos los sujetos fueron debidamente informados y el procedimiento se realizó de acuerdo a las normas establecidas por el Comité Ético del Hospital Universitario de Salamanca.

\subsubsection{Separación de CMN}

La MO procedente de donantes sanos se diluyó en medio Hanks y tras comprobar la ausencia de coágulos o restos de fibrina en la muestra se separó mediante gradiente de densidad por centrifugación con Ficoll durante 30 minutos a 500 xg siguiendo el método que previamente había descrito Minguell y cols. ${ }^{247}$. Las células mononucleadas $(\mathrm{CMN})$ procedentes de la interfase se lavaron dos veces con medio Hanks (10 minutos a 300xg). El precipitado celular obtenido, finalmente se resuspendió en $1 \mathrm{ml}$ del medio de expansión de CSM para proceder a su recuento celular en cámara de Neubauer. 


\subsubsection{Cultivo y expansión de CSM}

Para la expansión de las CSM se empleó el siguiente medio de cultivo: DMEM suplementado con SBF al 10\% y penicilina/estreptomicina 1\%. Una vez mezclados los componentes, se mantuvieron a $4^{\circ} \mathrm{C}$ durante su utilización.

Las CMN obtenidas a partir de MO se plantaron a una concentración de $10^{6}$ células $/ \mathrm{cm}^{2}$ en frascos de cultivo de fondo plano (Corning Incorporated, Corning, NY, USA) con medio de expansión y se incubaron en estufa a $37^{\circ} \mathrm{C}, 90 \%$ de humedad y $5 \%$ $\mathrm{CO}_{2}$. Transcurridos 5 días, se retiró el medio de cultivo eliminando de la placa todas las células no adheridas. Las placas se mantuvieron en cultivo hasta que alcanzaron aproximadamente un $80-90 \%$ de confluencia. El medio se cambió cada 3-4 días. Una vez que las células alcanzaron este punto, se procedió a despegado de las mismas para realizar el primer pase mediante tripsinización. Para ello, se retiró todo el medio de cultivo del frasco, se lavó con PBS estéril, y se incubó con tripsina durante 5 minutos a $37^{\circ} \mathrm{C}$ en atmósfera saturada de humedad y en presencia de $\mathrm{CO}_{2}$. Posteriormente, se neutralizó la tripsina con suero fetal. Las células obtenidas tras la tripsinización se plantaron de nuevo para su expansión a una concentración de 5000 células $/ \mathrm{cm}^{2}$ en frascos de cultivo de mayor superficie.

La selección de la población mesenquimal se lleva a cabo mediante sucesivos pases en cultivo y la caracterización de las CSM se hace en pase 3, siguiendo los criterios mínimos establecidos por la Sociedad Internacional de Terapia Celular ${ }^{248}$.

\subsubsection{Caracterización inmunofenotípica de las CSM}

Una vez obtenida la población mesenquimal en pase 3, se llevó a cabo su caracterización inmunofenotípica mediante citometría de flujo, empleando el siguiente panel de anticuerpos monoclonales y combinaciones de cuatro colores 
(FITC/PE/PerCPCy5.5/APC) e incluyendo además un tubo control de CSM sin marcar para corregir la elevada autofluorescencia de estas células:

- Tubo 1: CONTROL

- Tubo 2: CD90/CD166/ anti-HLA-DR /-

- Tubo 3: CD34/CD73/CD45/CD105

- Tubo 4: CD44/CD14/CD19/-

El cultivo de CSM se tripsinizó, las células se lavaron y se resuspendieron en PBS en tubos de citometría para proceder a su marcaje. La técnica de inmunofluorescencia directa se llevó a cabo con los anticuerpos monoclonales indicados. Para el marcaje, se emplearon las cantidades de anticuerpo recomendadas por las casas comerciales. Tras mezclar bien la muestra y los anticuerpos, se incubaron durante 15 minutos a temperatura ambiente y en oscuridad. Transcurrido este tiempo, se eliminó el exceso de anticuerpo mediante el lavado de las células con PBS y su centrifugación durante 10 minutos a 1200rpm. Finalmente se retiró el sobrenadante y se resuspendieron las células en $200 \mu 1$ de PBS. Los tubos se mantuvieron a $4^{\circ} \mathrm{C}$ y en oscuridad hasta el momento de su adquisición en el citómetro de flujo. La adquisición de las muestras se realizó en un citómetro de flujo modelo FACSCalibur (Becton Dickinson Biosciences, San Jose, CA, USA). La calibración del instrumento se llevó a cabo utilizando los protocolos previamente establecidos por el Servicio de Citometría de nuestro hospital. La adquisición de las muestras se hizo mediante el soporte informático del programa CellQuest ${ }^{\circledR}$ (Becton Dickinson Biosciences, San Jose, CA, USA) mientras que el análisis de las mismas se llevó a cabo gracias al programa Infinicyt (Cytognos, Salamanca, Spain). Se adquirieron un total de 50.000 células totales para proceder a su caracterización inmunofenotípica (Fig. 15). 

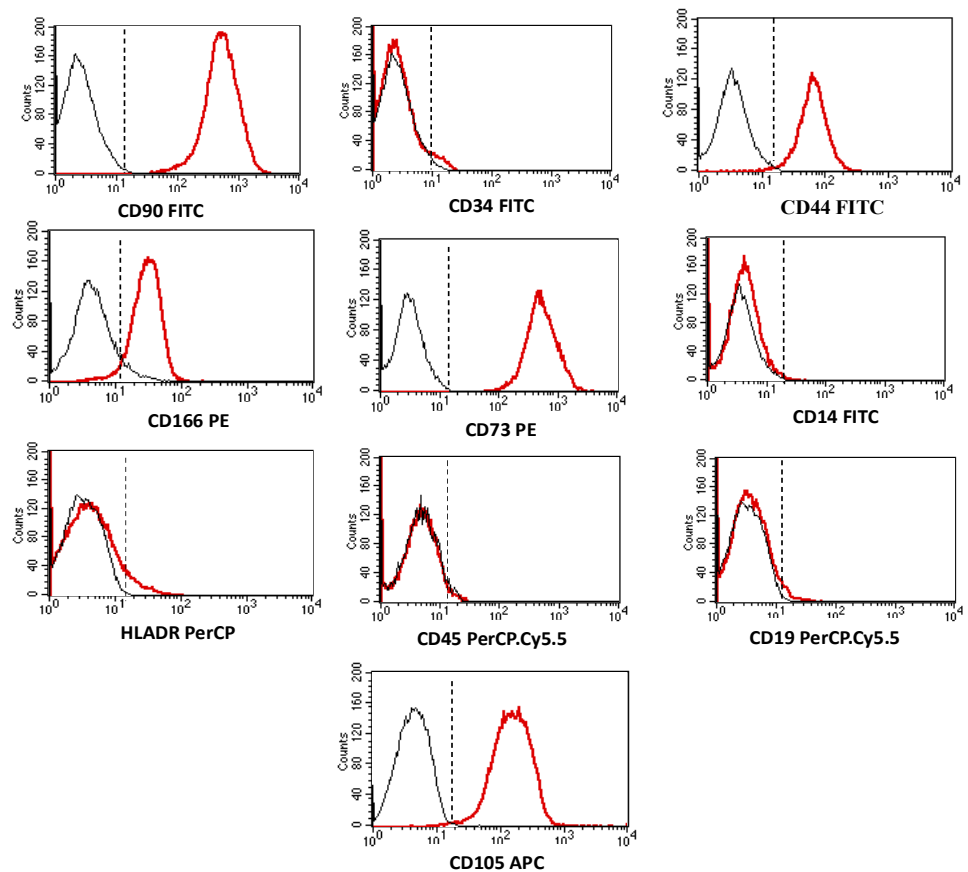

Fig. 15. Histogramas de la caracterización inmunofenotípica de las CSM humanas procedentes de donantes sanos, mediante citometría de flujo.

\subsubsection{Diferenciación de CSM}

La diferenciación de CSM requiere de los siguientes reactivos:

- Medio de diferenciación osteogénica (NH Osteodiff Medium, Miltenyi Biotec, Bergisch Gladbach, Germany).

- Medio de diferenciación adipogénica (NH Adipodiff Medium, Miltenyi Biotec, Bergisch Gladbach, Germany).

- Medio de diferenciación condrocítica (NH Chondrodiff Medium, Miltenyi Biotec, Bergisch Gladbach, Germany).

- Etanol (Merck KGaA, Darmstadt, Germany).

- PBS estéril (GIBCO ${ }^{\circledR}$, Invitrogen ${ }^{\mathrm{TM}}$ Corporation, Paisely, UK).

-NBT/BCIP solution (Nitroblue tetrazolium chloride/5-bromo-4-chloro-3 indolylphosphate, Roche, Basel, Switzerland).

- Oil-Red-O solution (Certistain ${ }^{\circledR}$ Merck KGaA, Darmstadt, Germany). 
- Isopropanol (Merck KGaA, Darmstadt, Germany).

- Paraformaldehído (Panreac, Barcelona, España).

- Hematoxilina (Merck KGaA, Darmstadt, Germany).

\section{Método de la diferenciación:}

- Diferenciación osteogénica. Para la diferenciación a osteoblastos, las CSM se plantaron en 2 placas sobre porta de $9.6 \mathrm{~cm}^{2}$ (Nunc, Denmark) CSM a una densidad de 5000 células $/ \mathrm{cm}^{2}$ y se mantuvieron con medio de expansión hasta alcanzar una confluencia del 80-90\%. En este momento, el medio de expansión de CSM es sustituido por medio de diferenciación osteogénica en una de las placas, mientras la otra se mantuvo con medio de expansión para utilizarse como control negativo. Se cambió el medio dos veces a la semana. Tras 10 días de cultivo, se lavaron las placas con PBS, se fijaron con etanol frío al $70 \%$ durante 10 minutos y se detectó la actividad fosfatasa alcalina mediante tinción con la solución NBT/BCIP siguiendo las indicaciones del fabricante (Fig. 16).

- Diferenciación adipogénica. En el proceso de diferenciación a adipocito, las CSM se plantaron en 2 placas sobre porta empleando las mismas condiciones de cultivo que en la diferenciación hacia osteoblastos. Una vez alcanzada la confluencia, se cambió el medio de expansión de CSM por medio de diferenciación hacia adipocito en una placa, mientras que la otra se mantuvo con medio de expansión (control negativo). Tras 21 días de cultivo en medio de diferenciación se lavaron con PBS, se fijaron con etanol al 70\% y se determinó la aparición de vacuolas lipídicas mediante tinción con rojo al aceite (Fig. 16).

- Diferenciación condrogénica. Para el proceso de diferenciación a condrocito, $5 \times 10^{5} \mathrm{CSM}$ en pase 3 se centrifugaron en tubos cónicos de $15 \mathrm{ml}$ (Corning Incorporated, 
Corning, NY, USA) y, sin resuspender el botón celular, se mantuvieron 21 días en cultivo con medio de diferenciación condrogénica o en medio de expansión de CSM. Pasado este tiempo, las muestras se fijaron con paraformaldehído al 4\% y se valoró la diferenciación hacia condrocito mediante el marcaje de las células con colágeno tipo II mediante técnicas de inmunohistoquímica. Los cortes se marcan con un anticuerpo primario de ratón anti-agrecano seguido de incubación con Biotina como anticuerpo secundario (Fig. 16).

\section{Diferenciación de CSM}

Diferenciación osteogénica

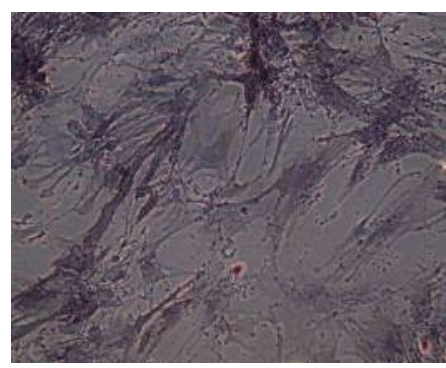

Tinción de Fosfatasa alcalina
Diferenciación adipogénica

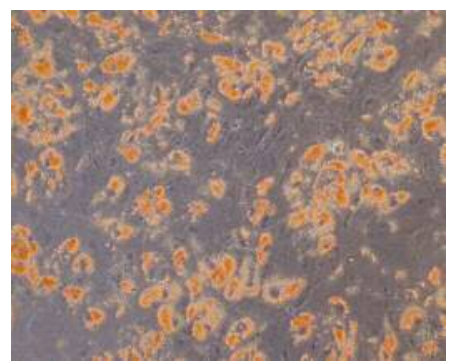

Tinción de Adipocitos con Oil Red
Diferenciación condrogénica

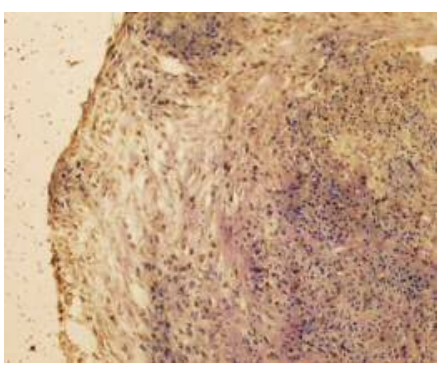

Inmunohistoquímica Ac Primario : anti-agrecano Ac secundario: Biotina

Fig. 16. Imágenes de las diferenciaciónes osteogénica, adipogénica y condrogénica a partir de CSM derivadas de MO.

\subsubsection{Transducción de las CSM}

Para la transducción de la población mesenquimal se empleó sobrenadante con particulas lentivirales que contiene el vector pLV-CMV-Luc2-ires-GFP durante $24 \mathrm{~h}$. Estos vectores portan los genes de la luciferasa y la GFP (Green Fluorescent Protein), los cuales posibilitarán el seguimiento posterior de la transducción.y por tanto el seguimiento celular. 
Se parte de un cultivo de CSM en pase 2 y cuando alcanza una confluencia próxima al 40\%, se cambia el medio de expansión por medio de transducción.

Medio de Transducción: una dilución 1:15 del sobrenadante de virus en medio de expansión mesenquimal. Además, se añadió polybrene (Sigma-Aldrich) a una concentración final de $8 \mu \mathrm{g} / \mu \mathrm{l}$ para aumentar la eficiencia de la transducción. Como control, siempre se mantiene en paralelo un cultivo sin medio de transducción.

Transcurridas 24 horas a $37^{\circ} \mathrm{C}$ en el incubador de $\mathrm{CO}_{2}$ se cambió el medio de transducción por medio fresco de expansión y se mantuvo el cultivo en condiciones estándar de expansión de CSM hasta el momento de su uso en el modelo animal. Las células $\mathrm{GFP}^{+}$fueron analizadas mediante citometría de flujo para determinar la eficiencia de la transducción.

Para el modelo animal se inyectaron subconjuntivalmente $2 \times 10^{5}$ CSM resuspendidas en $20 \mu 1$ de suero físiológico en el ojo derecho de los ratones BALB/c sometidos a estudio. 


\subsubsection{Administración de CSM}

Para la administración ocular de las hCSM se emplearon dos vías de administración:

\subsubsection{Administración tópica}

Los animales se inmovilizaron y se instiló en el ojo derecho una gota de $20 \mu 1$ con $2 \times 10^{5}$ hCSM $\mathrm{GFP}^{+}$resuspendidas en suero fisiológico estéril con ayuda de una pipeta automática. Se mantuvo el animal inmovilizado durante un minuto para favorecer la absorción celular y transcurrido ese tiempo se devolvió al animal con EICRo a la jaula.

\subsubsection{Administración subconjuntival}

Los animales se sedaron con isoflurano al $4.0 \%$ durante 2 minutos. Transcurrido ese tiempo la sedación se mantuvo con isoflurano al $2 \%$. Se instiló una gota de ciprofloxacino tópico y se inyectaron las $\mathrm{CSM} \mathrm{GFP}^{+}$por vía subconjuntival, cinco minutos después de la inducción de la sedación. Se inyectaron un total de $2 \times 10^{5}$ CSM $\mathrm{GFP}^{+}$resuspendidas en $20 \mu 1$ de suero fisiológico con una jeringa Terumo Myjector de $0,5 \mathrm{~mL}$ y una aguja montada de $27 \times 1 / 2 "-0,4 \times 12 \mathrm{~mm}$ a dos milímetros del limbo esclerocorneal. La inyección se llevó a cabo bajo un estereomicroscopio (Leica MZ6). Posteriormente se instiló profilácticamente povidona yodada (Betadine ${ }^{\circledR}$ ) tópica diluida al 50\% con suero fisiológico en el saco conjuntival. La inyección siempre se realizó en el ojo derecho, de modo que el ojo izquierdo se empleó como control experimental. Durante el periodo de tiempo que el ratón permaneció sedado con isofluorano se administraron $20 \mu \mathrm{l}$ de Buprenorfina vía subcutánea $0.1 \mathrm{mg} / \mathrm{kg}$ para asegurar un periodo de analgesia durante al menos $24 \mathrm{~h}$ y evitar el dolor subsecuente que esta vía de administración pueda generar. 


\subsubsection{Extracción de los ojos, la glándula lagrimal y el párpado}

Tras sacrificar al animal, se procedió a la enucleación de ambos ojos, realizando en primer lugar una cantotomía lateral, seccionando la musculatura extraocular y finalmente el nervio óptico. Una vez extraídos los globos oculares, para el estudio anatomopatológico con hematoxilina-eosina, se realizó una incisión escleral adyacente al nervio óptico incluyendo los mismos en frascos estériles con formaldehido al 5\% tamponado para su posterior procesado con el fin de llevar a cabo estudios sobre ellos. En segundo lugar se llevó a cabo la extracción de los párpados; para ello, antes de proceder a su exenteración de la órbita, se rasuró el pelo. La eliminación del exceso de pelo del párpado tiene como finalidad facilitar su inclusión para llevar a cabo el procesado y posterior estudio. Después, con el fin de facilitar su orientación a la hora de constituir los bloques de parafina, se marcó con un pincel y tinta china la cara que incluye la conjuntiva tarsal, fijando la tinción con Ácido pícrico (C6H3N3O7). Antes de su inclusión en parafina, se conservaron en formaldehido al 5\%. Para finalizar, se extirparon las glándulas lagrimales extraorbitarias, localizadas lateralmente y se incluyeron en paraformaldehido al 4\% (Fig. 17).

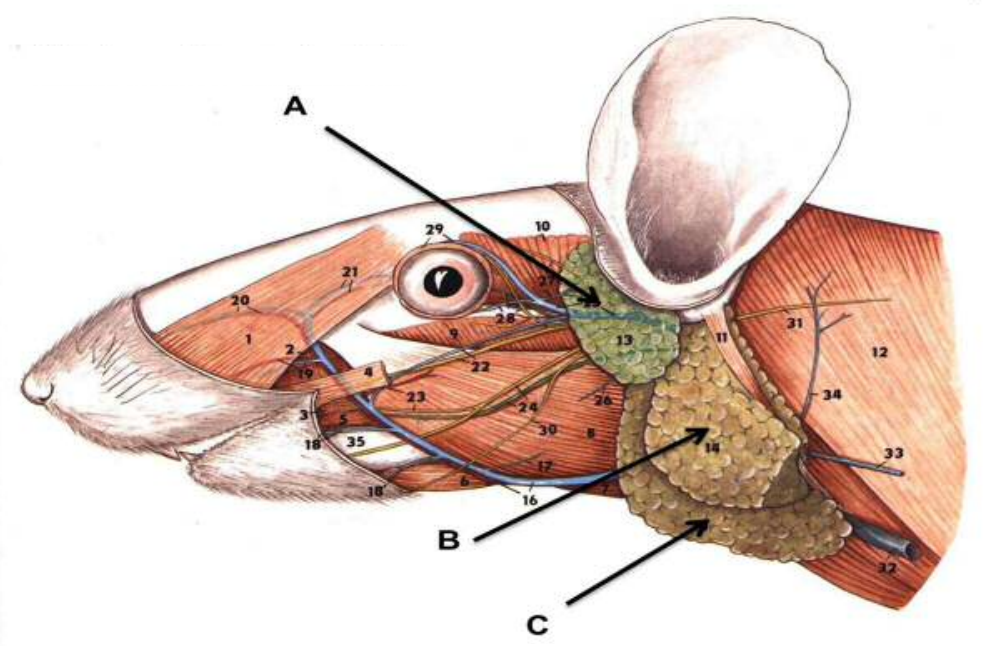

Fig. 17. Localización de las glándulas lagrimales extraorbitarias en el ratón. A. Glándula lagrimal extraorbitaria. B y C Glándulas salivares. 


\subsubsection{Procesamiento histológico para microscopía óptica}

Con el propósito de realizar un estudio anatomopatológico de los ojos de ratones que presentaban signos de EICRo y sus controles correspondientes, se realizó una evaluación de las muestras mediante microscopia óptica. Para el análisis, tanto el párpado como la glándula lagrimal murina se fijaron en formaldehido al $4 \%$ durante al menos $24 \mathrm{~h}$. Una vez fijadas las muestras, se colocaron en cassettes y se introdujeron en un procesador de inclusión de las muestras en parafina (Leica ASP 6025). Para ello, se realizaron los siguientes pasos:

- Fijación con formaldehido al 4\% (2 pases de 1h).

- Deshidratación utilizando alcoholes en concentraciones crecientes (se comienza con el alcohol al 70\% y se finaliza con alcohol absoluto al 100\%). La duración del proceso de deshidratación es de 2,5 h.

- Aclaramiento de las muestras con Xilol (miscible con la parafina) durante 1,5 h.

- Infiltración de las muestras con parafina a su temperatura de fusión que es de $60^{\circ} \mathrm{C}$. El proceso de infiltración dura aproximadamente unas $4 \mathrm{~h}$.

Una vez finalizados todos estos procesos, se sacaron las muestras del procesador y se introdujeron en la estación de parafina donde se elaboró el bloque de parafina con la ayuda de unos moldes metálicos. Los párpados se orientaron en el molde de forma horizontal y tanto los bloques de párpado como los de glándula se dejaron solidificar sobre la placa fría de la estación de inclusión de parafina. Una vez enfriados los bloques, se desmoldaron, se retallaron y se volvieron a enfriar para poder realizar los cortes. Mediente el uso de un microtomo de rotación (Leica RM 2235), se cortaron secciones de 3 micras de espesor. Los cortes se echaron a un baño de flotación, se pescaron con un portaobjetos y se secaron en estufas a $60^{\circ} \mathrm{C}$ durante 20 minutos. 


\section{-Tinción de Hematoxilina/Eosina}

Una vez que los portaobjetos salieron de la estufa de secado, la tinción con hematoxilina/eosina se llevó a cabo en el teñidor (Thermo Scientific Varistain Gemini). Este teñidor automático realiza todos los procesos implicados en la tinción:

- Desparafinación con xilol.

- Hidratación con alcoholes en concentraciones decrecientes.

- Tinción con Hematoxilina/Eosina.

- Deshidratación con alcoholes en concentraciones crecientes.

- Aclarado con Xilol

Después de este último paso se preparó la muestra para cubrirla con el cubreobjetos y el medio de montaje (DPX, Merck) de manera permanente, para su examen histológico empleando técnicas de microscopía óptica.

\section{-Tinción de PAS}

La reacción de PAS (Periodic Acid Schiff) es una de las tinciones más empleadas en histología y se utiliza para poner de manifiesto la presencia en los tejidos de grupos aldehídos generados por la oxidación previa de los hidratos de carbono. El fundamento de la reacción está basado en la oxidación de los tejidos con ácido peryódico para incrementar el número de grupos carbonilos (aldehídos o cetonas) presentes. Posteriormente, la muestra se trata con el reactivo de Schiff que reacciona con dos grupos aldehídicos contiguos dando lugar a una coloración rojo-púrpura característica. La tinción de PAS se realizo siguiendo los siguientes pasos:

1.- Los cortes se desparafinaron con Xilol.

2.- Se hidrataron con alcoholes en concentración decreciente en pases de 5 minutos cada uno.

3.- Oxidación con ácido Periódico al 0.5\% durante 13 minutos. 
4.- Lavado con agua destilada.

5.- Tinción con reactivo de Schiff, durante 20 minutos.

6.- Lavado con agua corriente unos 5 minutos.

7.- Se contrastó con Hematoxilina de Harris durante 2 minutos.

8.- Lavado con agua corriente durante 5 minutos.

9.- Deshidratación con alcoholes en concentracion creciente, 5 minutos en cada uno.

10.- Aclarado con Xilol, dos pases de 5 minutos cada uno.

11.- Montaje de los cubreobjetos con medio de montaje (DPX).

El resultado final de ésta tinción es:

- Núcleos: Violeta-negro.

-Polisacáridos simples, mucoproteínas, mucopolisacáridos neutros, membrana basal y glucolípidos: Rojo-púrpura.

Todas las imágenes de microscopía óptica de este trabajo fueron obtenidas con el Microscopio óptico Leica DMD 108 del Servicio de Anatomía Patológica del Complejo Asistencial Universitario de Salamanca.

\subsubsection{Técnicas inmunohistoquímicas}

Para evaluar la expresión de proteínas especificas de las CSM humanas en el párpado y glándula lagrimal del ojo derecho de los ratones $\mathrm{BALB} / \mathrm{c}$ receptores a los que el día +10 postrasplante se les había inyectado por vía subconjuntival $2 \times 10^{5} \mathrm{CSM}_{\mathrm{MO}}$ $\mathrm{GFP}^{+}$se realizaron técnicas de inmunofluorescencia.

Se emplearon secciones de muestras incluidas en parafina y procedentes de muestras congeladas:

- Secciones en parafina: Para la obtención de las secciones en parafina las muestras se procesaron siguiendo la metodología descrita en el apartado 3.2.5. 
- Secciones por congelación: Tanto el párpado como la glándula lagrimal se fijaron por inmersión en una solución de paraformaldehido al 4\% en tampón fosfato salino 0.1M, pH 7.4 (PBS) durante doce horas. Tras la fijación, se realizaron varios lavados con PBS durante al menos dos horas a temperatura ambiente con el objetivo de eliminar el exceso de fijador del tejido. Acto seguido los párpados y las glándulas lagrimales se crioprotegieron sumergiéndolos de forma seriada en una solución de sacarosa en PBS a concentraciones crecientes (desde el 10\% hasta el 30\%) durante dos días. Transcurrido este tiempo, las muestras se congelaron empleando medio OCT y se sumergieron en nitrógeno líquido.

Las secciones se obtuvieron mediante un criostato (MICROM HM 505N) a una temperatura de $-20^{\circ} \mathrm{C}$. El espesor de las secciones horizontales fue de $9 \mu \mathrm{m}$ y se recogieron en portaobjetos doblemente gelatinizados. Los portaobjetos se dejaron secar a temperatura ambiente y se almacenaron a $-20^{\circ} \mathrm{C}$ hasta que se produjo su procesamiento.

Con objeto de determinar la especificidad de los anticuerpos, se realizaron controles negativos con todos los anticuerpos utilizados, estableciéndose los siguientes grupos:

1. Eliminación de los anticuerpos primarios, para determinar la presencia de uniones inespecíficas entre los anticuerpos secundarios y el tejido.

2. Eliminación de los anticuerpos secundarios, para detectar la posible autofluorescencia del tejido.

No se encontró marcaje en ninguno de los controles realizados.

Los anticuerpos empleados para la identificación de las CSM humanas fueron:

- Anti-GFP (AB-5450, Abcam)

- Anti-mitocondria humana (MAB-1273, Millipore) 
Las imágenes de microscopia confocal fueron obtenidas con el Microscopio Laser Confocal Leica SP5.

\section{-Inmunohistoquímica de fluorescencia (Parafina)}

La técnica comenzó con la hidratación de los portaobjetos durante 8h en agua destilada y a temperatura ambiente. Después de la hidratación de los portas, se incubaron en jarras Coplin a $100^{\circ} \mathrm{C}$ en una solución $10 \mathrm{mM}$ de Citrato Sódico en Tween 20 al 0,05\% y pH6 durante $20 \mathrm{~min}$. Esta incubación facilita la recuperación antigénica eliminando los "puentes" de metileno producidos durante la fijación que pueden enmascarar los sitios de unión de los antígenos. Transcurridos los 20 min se retiró la solución de citrato y se añadió PBS a $4^{\circ} \mathrm{C}$. La técnica se continuó con tres lavados con PBS a temperatura ambiente durante $5 \mathrm{~min}$. Tras el último lavado procedimos a la preincubación de los portas en suero de bloqueo. El suero de bloqueo o de preincubación está compuesto por BSA 5\%, suero no inmune al 5\%, Triton X-100 al 0.2\% y PBS (el Tritón x-100 es un detergente que permeabiliza las membranas celulares facilitando la penetración de los anticuerpos). Las secciones se incubaron en esta solución durante $1 \mathrm{~h}$ en agitación y a temperatura ambiente. Y seguidamente se lavaron 3 veces con PBS durante 5 min en agitación a 120rpm.

- La incubación de los anticuerpos primarios anti-GFP 1/1000 y antiMitocondria humana $1 / 1000$ se produjo en cámara fría y agitación (50 rpm) durante toda la noche. Se volvieron a lavar con PBS 3 veces durante 5 min a una velocidad de $120 \mathrm{rpm}$.

- La incubación de los anticuerpos secundarios Alexa 488, dilución 1/750 y Alexa 555, dilución 1/1000, se incubaron durante $1,5 \mathrm{~h}$ en agitación $50 \mathrm{rpm}$ y temperatura ambiente. Los portas se lavaron 3 veces durante $10 \mathrm{~min}$ en PBS y se procedió a la tinción de los núcleos con DAPI dilución 1/1000 en PBS durante 4 min en 
oscuridad y finalmente los portas se montaron con un medio de montaje acuoso (VECTASHIELD), que preserva y favorece la fluorescencia.

\section{- Inmunohistoquímica de fluorescencia (Congelación)}

Las secciones se descongelaron a temperatura ambiente y se lavaron en PBS 3 veces, durante 5 min cada una, en agitación a $120 \mathrm{rpm}$ para rehidratar el tejido. Tras el último lavado se preincubaron los portas en suero de bloqueo. El suero de bloqueo o de preincubación estaba compuesto por BSA 5\%, suero no inmune al 5\%, Triton X-100 al $0.2 \%$ y PBS. El Tritón $\mathrm{x}-100$ es un detergente que permeabiliza las membranas celulares facilitando la penetración de los anticuerpos. Las secciones se incubaron en esta solución durante $1 \mathrm{~h}$ en agitación y a $\mathrm{T}^{\mathrm{a}}$ ambiente. $\mathrm{Y}$ seguidamente se lavaron 3 veces con PBS durante 5 min en agitación a 120rpm.

- La incubación de los anticuerpos primarios anti-GFP 1/1000 y anti-mitocondria humana 1/1000 se produjo en cámara fría y agitación $(50 \mathrm{rpm})$ durante toda la noche. Se volvieron a lavar con PBS 3 veces durante 5 min a una velocidad de $120 \mathrm{rpm}$.

- La incubación de los anticuerpos secundarios Alexa 488, dilución 1/750 y Alexa 555, dilución 1/1000, se realizó durante 1,5 h en agitación a 50 rpm y temperatura ambiente. Los portas se lavaron 3 veces durante 10 min en PBS y se procedió a la tinción de los núcleos con DAP dilución 1/1000 en PBS durante 4 min en oscuridad y finalmente los portas se montaron con un medio de montaje acuoso (VECTASHIELD), que preserva y favorece la fluorescencia.

\section{- Inmunohistoquímica para la determinación de la actividad Caspasa 3}

La actividad de la Caspasa 3 se determinó en la conjuntiva tarsal de ratones BALB/c control y con EICRo. Las muestras se procesaron tal y como se describe en el apartado 3.2.6.1. Se empleó agua oxigenada al 3\% durante 20 min con el fin de inhibir 
la peroxidasa endógena, se lavaron los portas durante de 5 min con PBS y se bloquearon durante 60 min con suero, con el fin de evitar un marcaje inespecífico. La determinación de la Caspasa 3 se continuó mediante el sistema automatizado BOND-MAX® (Leica Biosystems, Melbourne, Australia). El sistema incubó los portas durante 60 min con el anticuerpo primario policlonal de conejo anti Caspasa 3 (Cell Signaling Technology, MA, USA) empleando una dilución 1:400. Para el revelado, se empleó la tecnología de polímero compacto Novolink Polymer Detection System ${ }^{\circledR}$ (Leica Microsistemas, Barcelona, España; RE7140-K) durante 8 min y Diaminobencidina (DAB) durante 10 min. Concluimos el proceso con una tinción de la muestra con hematoxilina.

\subsubsection{Técnica de la citología de impresión}

Las muestras se recogen en tiras de papel de filtro de $5 \times 3 \mathrm{~mm}$ de tamaño, con una esquina en pico para su mejor manejo. Las tiras de papel se colocan sobre las distintas áreas de la superficie ocular durante unos 3 segundos, haciendo una ligera presión con la punta de unas pinzas tras aplicar anestesia tópica en el fondo de saco. Tras la obtención de las muestras, se fijan con alcohol de 96\% durante, al menos, 10 minutos y procediéndose posteriormente a su tinción con PAS-hematoxilina que pone de manifiesto la mucina de las células caliciformes y las estructuras celulares basófilas.

\subsubsection{Animales con EICR}

\subsubsection{Monitorización de la EICR}

En los ratones trasplantados con MO y esplenocitos se evaluaron mediante un sistema de puntuación estándar que va de 0 a 2 , dos veces a la semana. Se incorporaron 5 rasgos clínicos de evaluación que facilitan la monitorización de la evolución de la $\mathrm{EICR}^{249}$ : 
1- Pérdida de peso

2- Postura (encorvamiento)

3- Actividad

4- Textura de la piel

5- Integridad de la piel

\subsubsection{Monitorización de la EICRo}

Además de estos 5 rasgos clínicos de los que nos servimos para la monitorización de la EICR, se valoraron las características macroscópicas del ojo derecho y del ojo izquierdo de estos ratones independientemente, 2 veces por semana, teniendo en cuenta: el pelo periocular, el borde palpebral y el blefarospasmo. Se establecieron 3 grados de afectación clínica dependiendo de los signos macroscópicos observados en los ratones ${ }^{224}$ :

- La valoración de 0. Se corresponde con ratones que no presentaban pérdida de pelo alrededor de los ojos, ni costras ni enrojecimiento del borde palpebral, no existía blefarospasmo.

- La valoración de 1. Se corresponde con una de las siguientes características: perdida de pelo periocular, costras o enrojecimiento del borde palpebral y blefarospasmo.

- La valoración de 2. Se corresponde con ratones que presentaban dos o tres de las características mencionadas anteriormente.

Los ratones se agruparon en función de su tratamiento en diferentes jaulas con cobertor. La monitorización individualizada de los ratones permitió un seguimiento de la evolución de la EICR y el efecto diferencial que la inyección subconjuntival de CSM $\mathrm{GFP}^{+}$pudiese producir en el ojo derecho. El seguimiento de cada ratón se hizo a tiempo 0 y a partir de ese momento dos veces a la semana. 


\title{
3.2.8.3. Experimento murino
}

Con el propósito de generar un modelo de EICRo murino, se establecieron 4 subgrupos experimentales (Tabla 7). Cada uno de los cuales, se repitió un mínimo de 5 veces.

- TBI (total body irradiation): Control de irradiación.

- MO: Control de MO (infusion de $5 \times 10^{6}$ celulas de MO).

- EICR ocular: Infusion de $5 \times 10^{6}$ celulas de MO $+5 \times 10^{6}$ esplenocitos

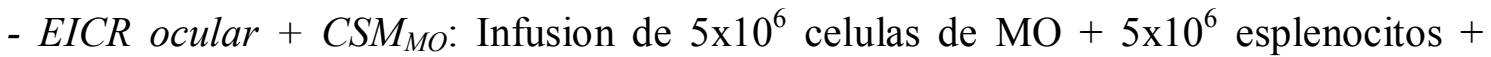
$2 \times 10^{5} \mathrm{CSM}_{\mathrm{MO}}$.

\section{Tabla 7. Relación de los subgrupos del modelo experimental}

\author{
MODELO EXPERIVENTAL MRINO
}

\begin{tabular}{|c|c|c|c|c|c|}
\hline Grupo & $\begin{array}{l}\text { Irradliación } \\
8550 \mathrm{CGy}\end{array}$ & $\begin{array}{l}\text { N0 } \\
\$ \leqslant 110^{6}\end{array}$ & $\begin{array}{r}\text { BAZO } \\
5 x 10^{\circ}\end{array}$ & $\begin{array}{c}\text { Admininistración } \\
\text { sulbconijutivival } \\
\text { de CSM } \\
\text { Dino }+10\end{array}$ & $\begin{array}{c}\mathrm{N}^{0} \\
\text { Ritones } \\
\text { receptores } \\
B: L B \text { B' }\end{array}$ \\
\hline
\end{tabular}

\begin{tabular}{|c|c|c|c|c|}
\hline 1.TBI & 10 & $\mathrm{NO}$ & NO & 1 \\
\hline 2. $\mathrm{MlO}$ & SI & No & NO & 3 \\
\hline 3. EICHo & SI & SI & No & 5 \\
\hline 4. EICHo+CSM & SI & SI & $\$ I$ & 5 \\
\hline
\end{tabular}

El experimento se realizó 5 veces, empleando en cada ocasión 14 ratones $\mathrm{BALB} / \mathrm{c}$ y 3 ratones C57BL/6.

Todos los ratones trasplantados con $\mathrm{MO}$ y con $\mathrm{MO}$ y esplenocitos se mantuvieron durante 4 semanas postrasplante en el animalario. Transcurrido ese tiempo se sacrificaron e inmediatamente después se realizó la enucleacion de los ojos. 


\section{- Grupo experimental TBI}

El proceso de irradiación se llevó a cabo empleando un irradiador de muestras biológicas Gammacell 1000. Este irrediador se encuentra situado en el animalario del Edificio Departamental de la Universidad de Salamanca y emplea una fuente de Cesio 137.

Los ratones receptores $\mathrm{BALB} / \mathrm{c}$ hembra con un peso aproximado de $20 \mathrm{~g}$ se sometieron a una irradiaron corporal letal de 850 cGy dividida en dos fracciones de 425 cGy separadas por un intervalo de tiempo de 4 horas (Fig. 18).

De acuerdo con nuestra experiencia los animales que se sometan a irradiación corporal total (TBI), presentan una supervivencia aproximada de $10-14 \mathrm{~d}$ postirradiación. Empleando técnicas de punción mandibular se extraerá SP a los ratones de este grupo experimental el día 8 post-irradiación. Los ratones cuyo hemograma presenta un recuento inferior a 100 neutrófilos/ $\mu 1$ se sacrifican mediante anestesia seguida de dislocación cervical como criterio de punto final.

\section{GRUPO EXPERIMENTAL TBI}

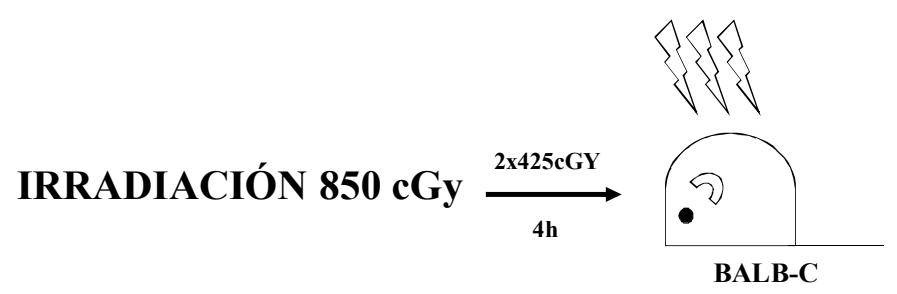

Fig. 18. Esquema del modelo de control de irradiación.

\section{- Grupo experimental de trasplante de MO}

Los ratones receptores $\mathrm{BALB} / \mathrm{c}$ recibieron $4 \mathrm{~h}$ después de la segunda irradiación un total de $5 \times 10^{6}$ células procedente de los fémures y las tibias de los ratones donantes C57BL/6 por vía endovenosa a través de la cola (Fig. 19). Las células procedentes de la 
MO se resuspendieron en un volumen final de $300 \mu 1$ de RPMI. En el desarrollo de este grupo experimental la supervivencia de los animales no se vió comprometida constituyendo por tanto un buen modelo murino de control de irradiación y de trasplante.

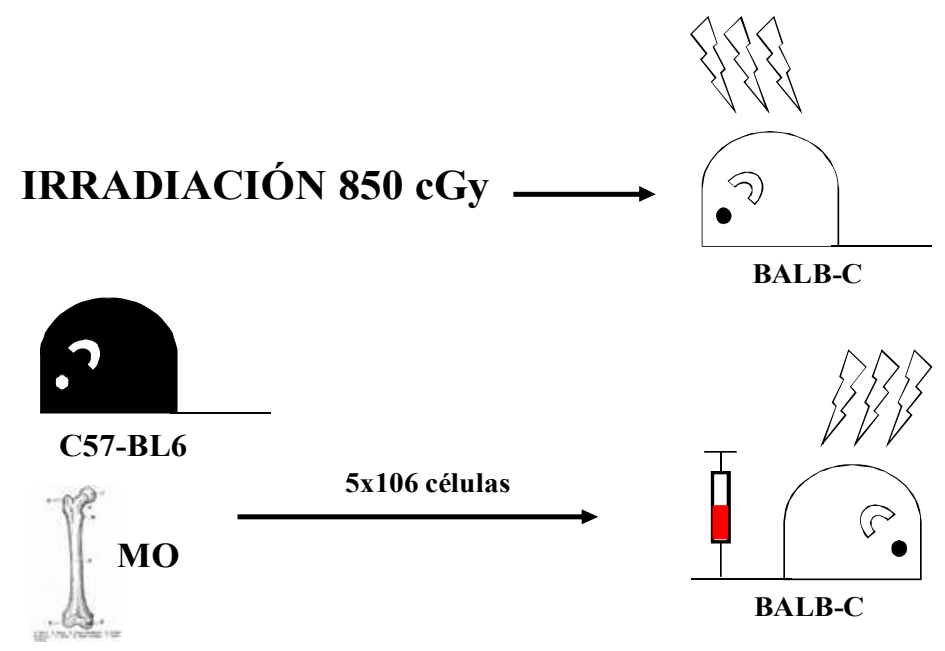

Fig. 19. Esquema del modelo de trasplante de MO murino.

\section{- Grupo experimental EICRo}

Los ratones receptores $\mathrm{BALB} / \mathrm{c}$ recibiran $4 \mathrm{~h}$ después de la segunda irradiación por vía endovenosa a través de la cola un total de $5 \times 10^{6}$ células procedente de los fémures y las tibias y $5 \times 10^{6}$ de células procedentes del bazo de los ratones donantes C57BL/6 resuspendidas en un volumen de $300 \mu 1$ de RPMI. Estos procedimientos requieron de la inmovilización del ratón receptor en una jaula donde con una bombilla infrarroja de calor se dilataron las venas laterales de su cola. En los grupos en los que se generó EICR se asumió la posibilidad de que en un 10-20\% de los animales pudieran desarrollar infección o fallo de injerto. 
El rescate de la irradiación corporal total se debe a las células procedentes de la MO mientras que las células maduras del bazo del ratón donante C57BL/6 son las inductoras de la EICR en el ratón receptor BALB/c (Fig. 20).

\section{GENERACIÓN DE EICHo TRASPLANTE DE MO y ESPLENOCITOS}
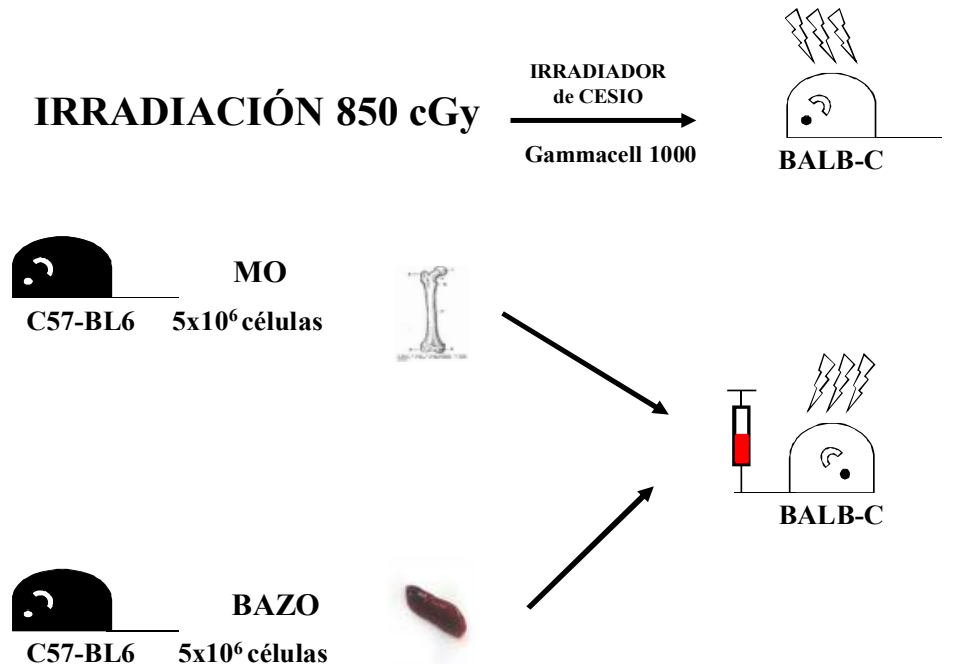

Fig. 20. Esquema del modelo murino de trasplante y generación de EICR.

- Grupo experimental EICRo tratado con CSM administradas por vía subconjuntival.

Este grupo experimental se genera del mismo modo que el descrito en el apartado anterior con la salvedad de que estos ratones se trataron con CSM administradas por vía subconjuntival el día +10 postrasplante (Fig.21). El cultivo in vitro de $\mathrm{CSM}_{\mathrm{MO}} \mathrm{GFP}^{+}$se tripsinizaron, se recontaron y un total de $2 \times 10^{5}$ células se resuspendieron en $20 \mu 1$ de suero fisiológico y mediante jeringas de $27 \mathrm{G}$ se administraron en el ojo derecho de los ratones con EICRo por vía subconjuntival. Durante el periodo de tiempo que el ratón permaneció anestesiado con isofluorano se le inyectó por vía subcutánea $20 \mu \mathrm{l}$ de Buprenorfina a una dosis de $0.1 \mathrm{mg} / \mathrm{kg}$ que asegura un período de analgesia superior a $12 \mathrm{~h}$. 


\section{GENERACIÓN DE EICHO TRASPLANTE DE MO y ESPLENOCITOS INYECCIÓN SUBCONJUNTIVAL DE CSM $_{\text {MO }}$}
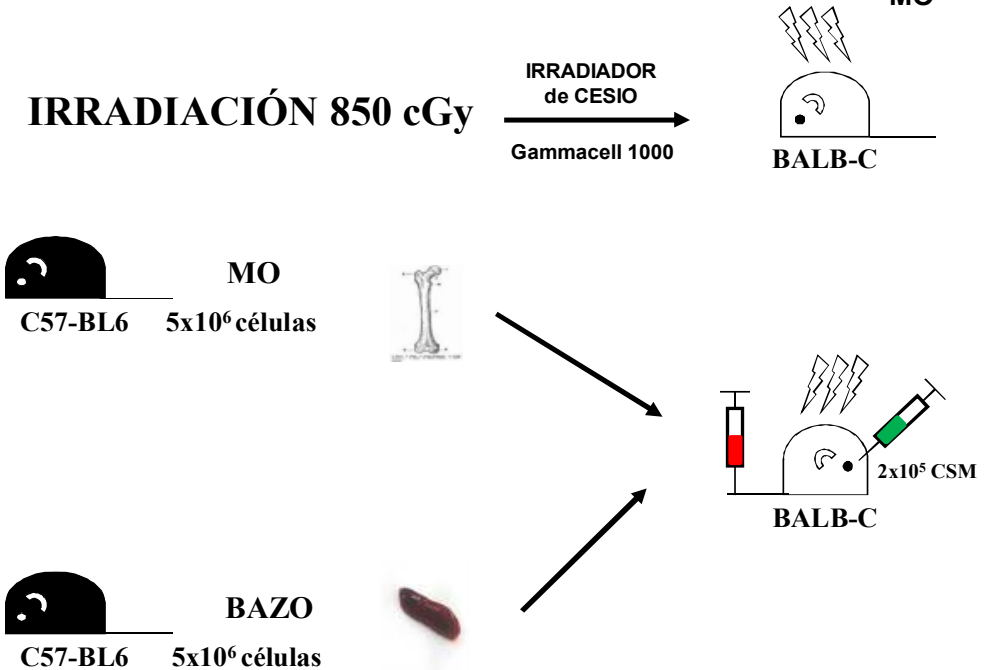

Fig. 21. Esquema del modelo de generación de animales con EICRo y su tratamiento con $\mathrm{CSM}_{\mathrm{MO}}$ administradas por vía subconjuntival.

\subsubsection{Modelo de punto final}

El modelo C57BL/6 en BALB/c es un modelo de trasplante murino validado y contrastado en numerosas publicaciones. Para el desarrollo de este proyecto, hemos puesto a punto un criterio de punto final basado en la aplasia medular. Por tanto, de los valores hematimétricos de la SP murina se determinaron los criterios de punto final con el fin de evitar un sufrimiento animal innecesario.

\subsubsection{Fluorescencia y luminiscencia}

La fluorescencia es la emisión de fotones que tiene lugar como resultado del regreso al estado basal de energía de una sustancia, denominada fluorocromo y que previamente ha sido excitada a un nivel de energía superior mediante la absorción de fotones excitantes (395-600nm), de mayor energía que los emitidos. El tiempo entre la excitación y la emisión es del orden de milisegundos. 
Los fluorocromos pueden ser usados como trazadores en células modificadas genéticamente para su expresión bajo el control de determinados promotores. La detección de fotones de la correspondiente longitud de onda es evidencia de la presencia del trazador. Un ejemplo de fluorocromo es el de la proteína verde fluorescente (GFP), se obtiene a partir de la medusa Aequorea victoria, que emite luz verde (a 509nm) cuando se excitada con luz violeta $(395 \mathrm{~nm})^{250}$.

La fluorescencia es de gran utilidad para el seguimiento de trazadores en secciones de tejidos, pero debido a su baja penetrancia es menos útil para generar imágenes de modo no invasivo in vivo.

\subsubsection{Bioluminiscencia}

La luminiscencia es la producción de fotones de luz como resultado de una reacción química ${ }^{251}$ y concretamente, en el caso de la bioluminiscencia los fotones son el producto de una reacción de oxidación de un sustrato catalizado por una enzima. El ejemplo más utilizado es el de la luciferasa de la luciérnaga Photinus Piralis (FLuc) que cataliza la reacción de oxidación de la luciferina (Fig. 22).

\section{Luciferina}
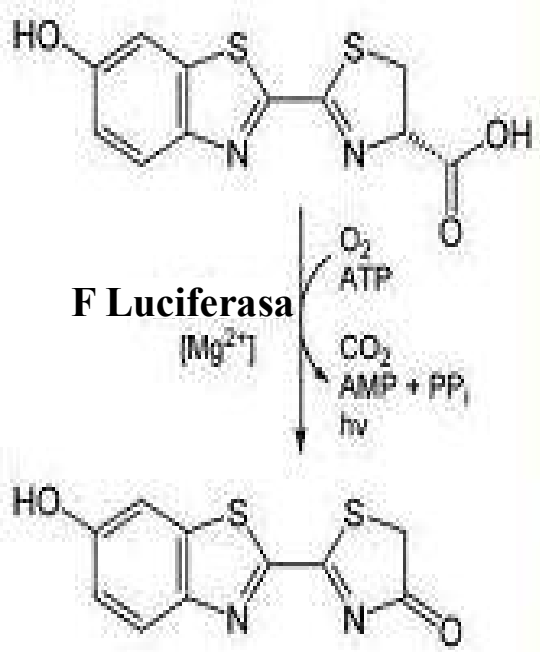

Oxoluciferina

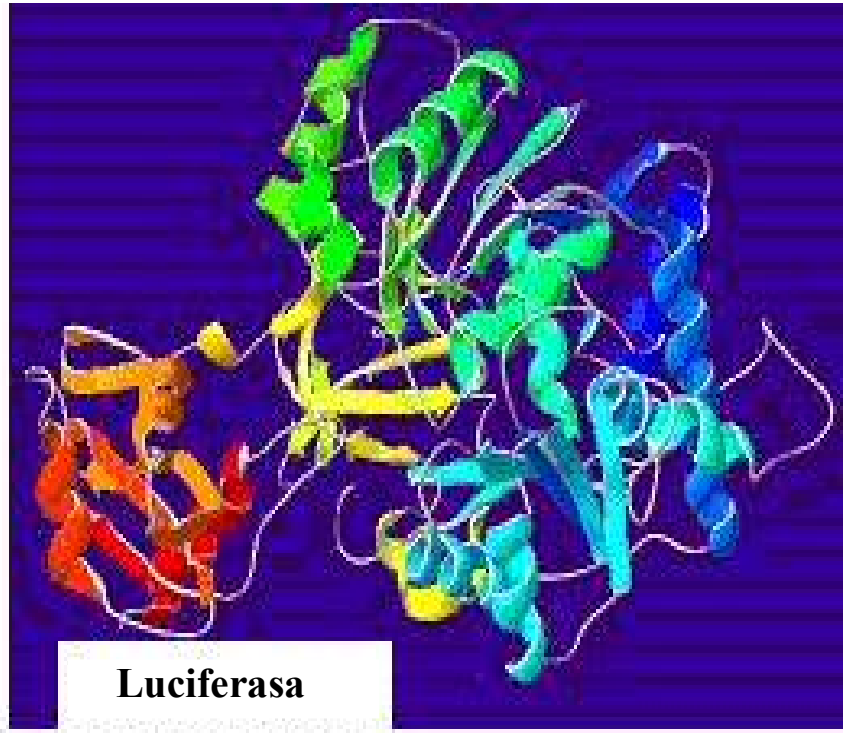

Fig. 22. Reacción catalizada por la FLuc en la cual se obtienen fotones a partir de la luciferina y ATP. 
Las luciferasas que emiten un gran porcentaje de los fotones desde el rojo al infrarrojo (600-900nm) son más ventajosas, ya que la atenuación tisular de los fotones se minimiza en esta región de espectro. Por ello tienen mayor penetrancia, siendo óptimas para el uso en modelos in vivo no invasivos.

La emisión de fotones se evidencia por la presencia de un trazador. Las luciferasas tienen múltiples ventajas como trazadores:

a) Se pueden introducir genéticamente en las células, de modo que no se diluyen a pesar de que las células proliferen.

b) La cantidad de fotones generados es proporcional a la cantidad del trazador expresado por las células.

c) Los mamíferos carecen casi por completo de reacciones quimioluminiscentes, por lo que el fondo es prácticamente nulo.

d) Los instrumentos de detección de fotones son muy sensibles ${ }^{252}$.

Sin embargo, una desventaja de las luciferasas es que como trazadores requieren de la administración del sustrato al animal de experimentación para que la emisión de fotones tenga lugar.

Las técnicas ópticas de imagen requieren que las células implantadas en los animales a estudiar expresen el gen trazador de modo que se permita su seguimiento in vivo. Una de las estrategias más empleadas para la incorporación de tales genes, por ejemplo FLuc, es el uso de vectores víricos, como pueden ser los lentivirus. La capacidad de los vectores lentivíricos para transducir todo tipo de células, incluyendo las que no están en división, los hace especialmente útiles para introducir material genético en células troncales adultas ${ }^{253}$. 


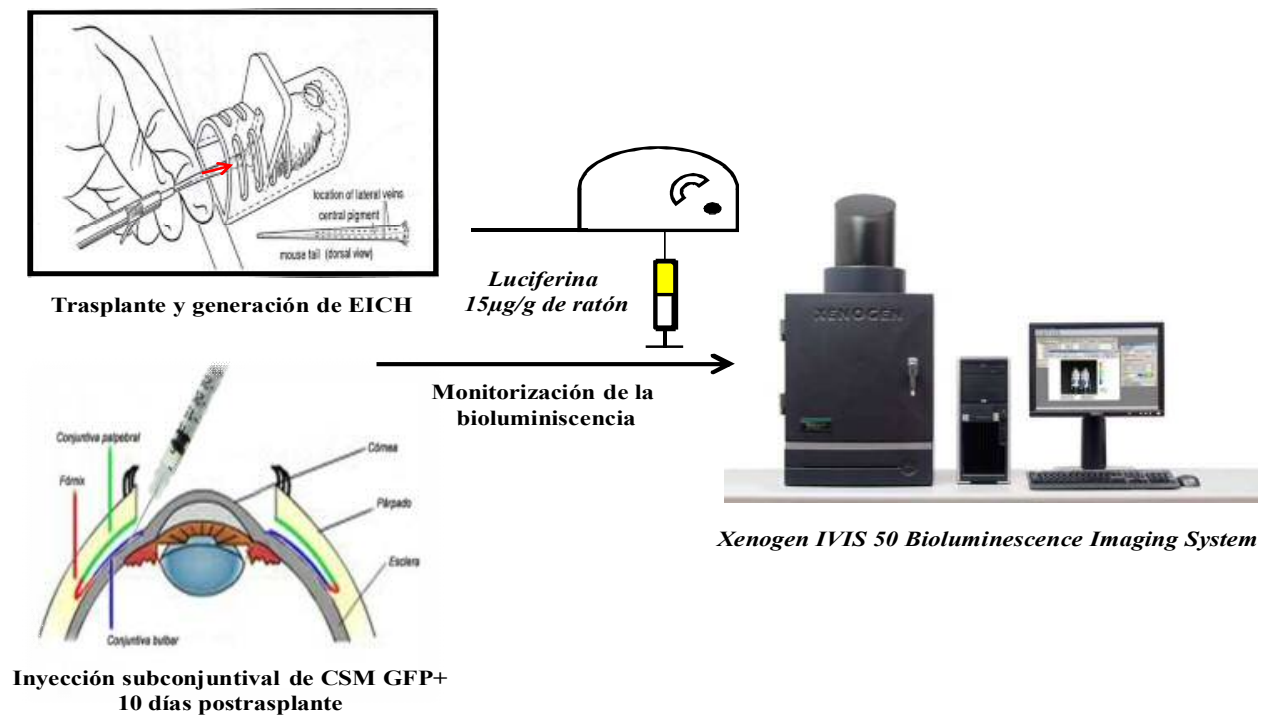

Fig. 23. Resumen la estrategia utilizada en la plataforma de análisis basada en procedimientos de biolumuniscencia no invasiva (BLI).

\subsubsection{Análisis de la bioluminiscencia in vivo}

La localización de las CSM se pudo detectar gracias a la actividad luciferasa que presentan las mesenquimales tras ser transducidas. Para ello, se inyectó a los ratones una dosis de $15 \mu \mathrm{g}$ de luciferina/g de ratón por vía intraperitoneal, empleando una solución de luciferina (Promega, Madison, WI, USA) a una concentración de $15 \mathrm{mg} / \mathrm{ml}$ reconstituida en PBS. Los animales se anestesiaron con isofluorano (Forane, Abbot Laboratories, Madrid) y se colocaron en los soportes para facilitar la toma de imágenes en un sistema de bioluminiscencia Xenogen IVIS 50 (Xenogen Corporation, Caliper Life Science, Alameda, CA, USA). La toma de imágenes comenzó transcurridos 10 minutos de la inyección del sustrato (luciferina). En este momento la luciferasa alcanza su máxima actividad y permite que la emisión de fotones sea constante. Las imágenes se adquirieron y analizaron empleando el programa Living Image 2.50 .1 (Xenogen Corporation, Caliper Life Science, Alameda, CA, USA). Para el análisis se determinaron las regiones de interés (ROI) basadas en el contorno de las mismas y 
calculando para cada una de ellas la emisión de fotones/segundo. La emisión de bioluminiscencia se analizó los días $+2,+7,+14,+21$ y +28 de la inyección subconjuntival de las CSM transducidas.

\subsubsection{Medida de la producción de lágrima. Prueba del rojo}

\section{fenol (PRT)}

Con la finalidad de valorar el volumen de lágrima se ha utilizado la prueba del rojo fenol (PRT-TEST, Phenol Red Thread. Tianjin Jingming New Technological Development Co., Ltd. Tianjin, China) en la que se aloja un fino hilo de algodón impregnado con rojo fenol sobre el tercio lateral del párpado inferior de forma parecida a una tira de Schirmer. La absorción del fluido lagrimal ligeramente alcalino $(\mathrm{pH} 7,4)$ induce un cambio de color del rojo al amarillo en el hilo. La medida del volumen de lágrima se lleva a cabo durante un tiempo de 30 segundos en comparación con la prueba de Schirmer que tarda 5 minutos ${ }^{254}$.

Para adaptar esta técnica al uso murino, el hilo de rojo fenol de $7.5 \mathrm{~cm}$ de longitud empleado en humanos se cortó en fragmentos de $1 \mathrm{~cm}$ que son los que se alojaron con la ayuda de unas pinzas en el menisco del canto lateral superior de cada ojo del ratón BALB/c (Fig.24). Como se realiza en la exploración adaptada a seres humanos, la medida del volumen de lágrima se llevó a cabo durante un tiempo de 30 segundos. La longitud de la porción humedecida del hilo que adquiere una coloración rojiza se fotografió en un microscopio (Olympus Provis AX70) y se midió con la ayuda de un programa de análisis de imagen (http://rsbweb.nih.gov/ij/) (Fig.25). Las mediciones de la producción de lágrima se hicieron sin necesidad de anestesia tanto en ratones $\mathrm{BALB} / \mathrm{c}$ control (trasplantados con $\mathrm{MO}$ ) como en los que se generó el modelo de EICR. 


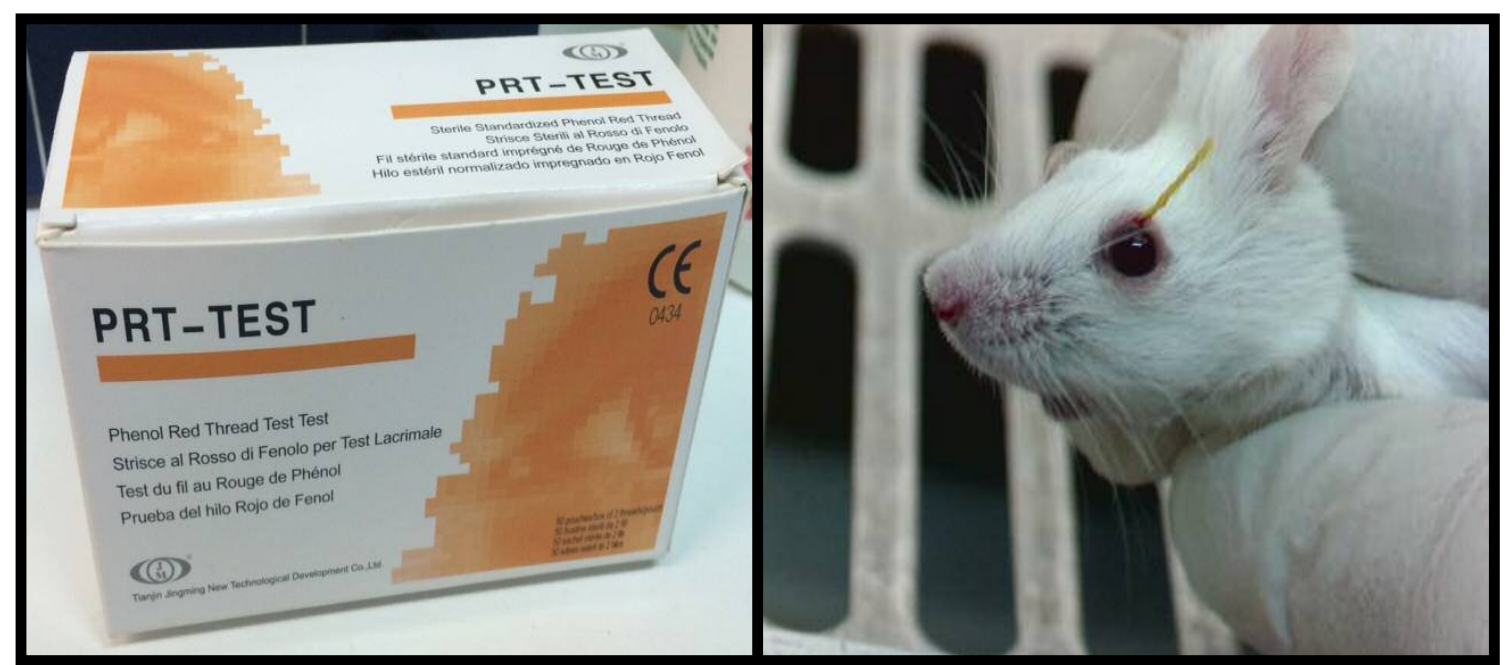

Fig. 24. Imagen de la presentación comercial de los hilos de rojo fenol empleados e imagen de la medición de la producción de lágrima de un ratón $\mathrm{BALB} / \mathrm{c}$.

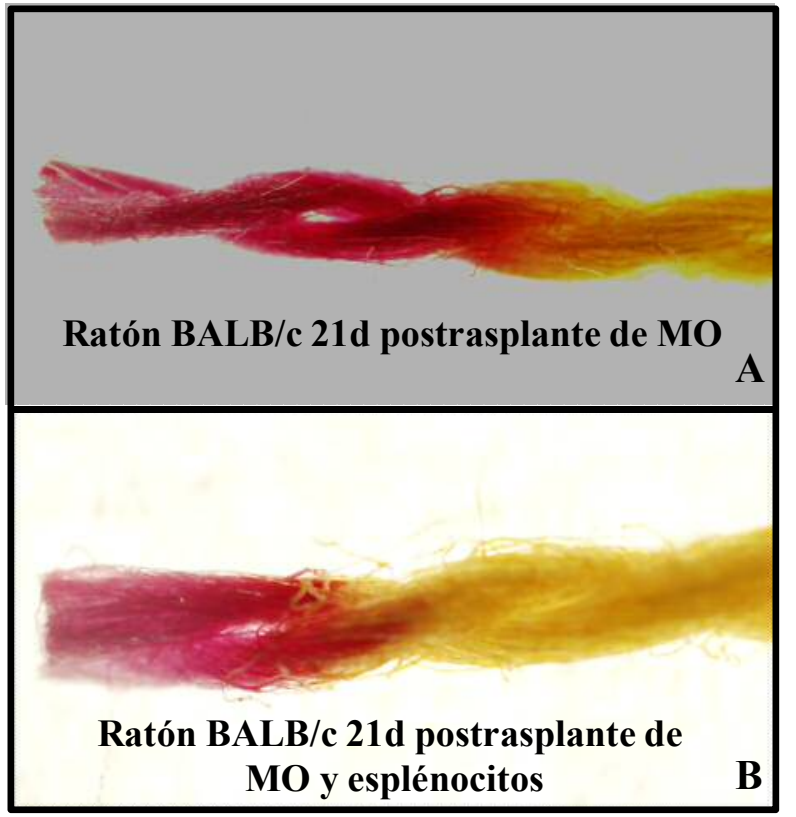

Fig. 25. Medida del volumen de lágrima mediante la impregnación del hilo rojo fenol. A. A los 21 días postrasplante en ratón BALB/c MO (control). B. A los 21 días postrasplante en ratón BALB/c con EICR.

\subsubsection{Osmolaridad de la película lagrimal}

Para establecer la osmolaridad de la película lagrimal se emplea un osmolarimetro que permite conocer el grado de salinidad de la lágrima255, lo cual 
determina la salud y estabilidad de la película lagrimal, que se ve alterada con la sequedad ocular dado que, al disminuir la cantidad de lágrima, aumenta su concentración salina. Empleamos un osmolarimetro TearLab (TearLab Corp San Diego, CA, EE.UU.) (Fig. 26) que permite una determinación precisa, rápida, e indolora de la osmolaridad lagrimal y que da una medida cuantitativa en pocos segundos y ha facilitado la medición de la osmolaridad en el entorno clínico. Su chip de alta tecnología funciona como sistema de toma y medición de un solo uso que permite simultáneamente recoger y analizar la impedancia eléctrica de una muestra de lágrima (tecnología "labon-a-chip”). Permite conocer el grado de salinidad de la lágrima, cosa que determina la salud y estabilidad de la película lagrimal, que se ve alterada con la sequedad ocular dado que, al disminuir la cantidad de lágrima, aumenta su concentración salina. Los resultados de osmolaridad obtenidos con este equipo son fiables y se correlacionan con el grado de afectación de la enfermedad. Esta tecnología se ha podido aplicar en los modelos murinos gracias a que requiere de un escaso volumen de lágrima (50nl) que se obtiene directamente del canto lateral del ojo del ratón BALB/c por una acción capilar pasiva, para medir los electrolitos. Se aplicaron los procedimientos de control de calidad antes de las mediciones experimentales de acuerdo con las instrucciones del fabricante. El lector del TearLab convierte la información obtenida de cada chip desechable en un valor cuantitativo en miliosmoles por litro. El proceso completo desde la toma de muestra hasta la obtención del resultado requiere únicamente unos 10 segundos. Las mediciones en los dos ojos se realizaron sin anestesia con la finalidad de no alterar el resultado obtenido. 
Osmolarimetro TearLab

Lector de Osmolaridad

Chip TearLab

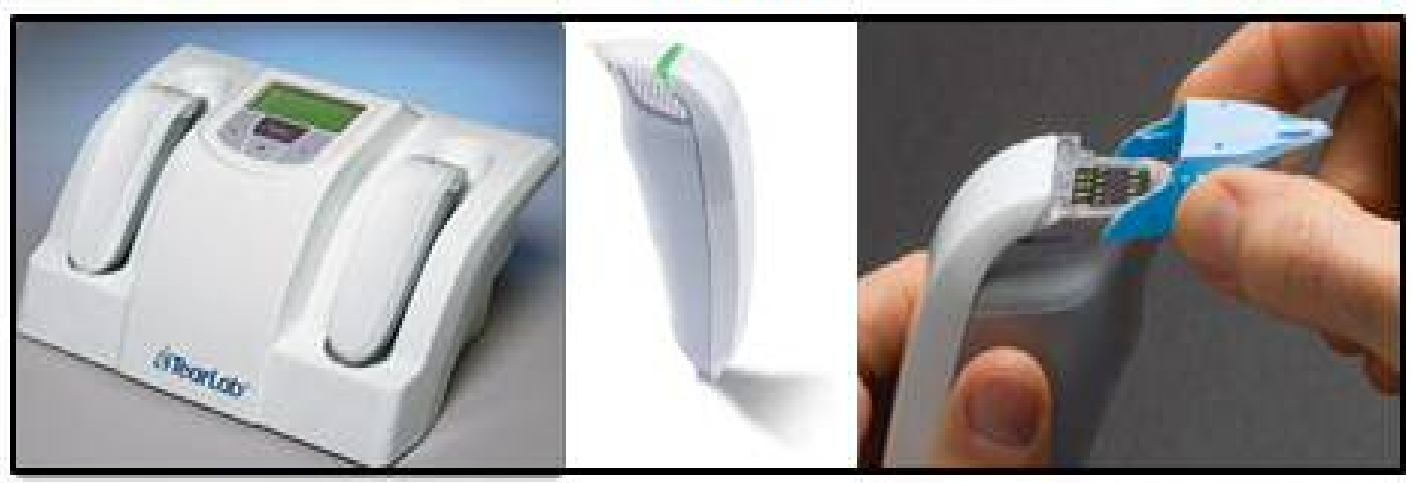

Fig. 26. Imagen del osmolarimetro TearLab y de los chips empleados en cada medición.

\subsubsection{Infiltración linfocitaria de la glándula lagrimal en ratones}

\section{BALB/c con EICRo}

Una vez que el examen histológico de los párpados y la glándula lagrimal en el modelo de trasplante y generación de EICRo C57BL/6 en BALB/c reveló la existencia de infiltración linfocitaria inflamatoria se puso a punto y se procesaron para analizar mediante citometría de flujo las muestras murinas de glándula lagrimal. Transcurridas 4 semanas de la inyección subconjuntival de hCSM GFP+ en el ojo derecho de ratones BALB/c a los que se les había generado EICRo. Se sacrificó al animal y se procedió a la enucleación de ambos ojos con extirpación de las glándulas lagrimales. El tejido glandular se disgregó mecánicamente entre dos portas esmerilados. El producto obtenido se depuró a través a de filtros de $40 \mu \mathrm{m}$ de poro y tras el lavado de las células

con PBS, se determinó el número de células obtenidas. Un total de $5 \times 10^{5}$ células procedentes de la glándula lagrimal derecha e izquierda se marcaron con la siguiente combinación de anticuerpos:

- H2D ${ }^{\mathrm{b}}$ FITC/H2D ${ }^{\mathrm{d}}$ PE/CD3 PerCP-Cy5.5/CD45 APC 


\section{- H2D ${ }^{\mathrm{b}}$ FITC/H2D ${ }^{\mathrm{d}}$ PE/CD8 PerCP-Cy5.5/CD4 APC}

El análisis de este panel de anticuerpos con el que se marcaron las células procedentes de ambas glándulas nos permitió establecer la infiltración linfocitaria y su origen autólogo o alogénico.

Los estudios de citometría se llevaron a cabo en un citómetro FACS Calibur (Becton Dickinson), empleamos el programa de adquisición CellQuestR (Becton Dickinson Bioscience) y las muestras se analizaron mediante el programa Infinicyt1.1 (Cytognos S.L.). 



\section{Resultados}

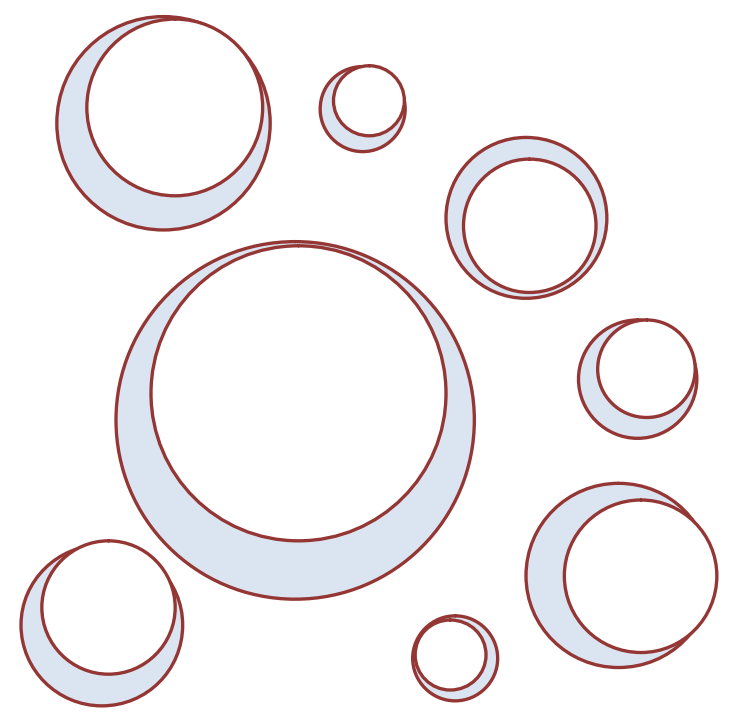





\subsection{Modelo de generación de la EICRo}

El esquema del modelo experimental empleado se resume de nuevo en la Figura 27.

\section{MODELO DE GENERACIÓN DE EICHo y ADMINISTRACIÓN SUBCONJUNTIVAL DE MSC GFP+}

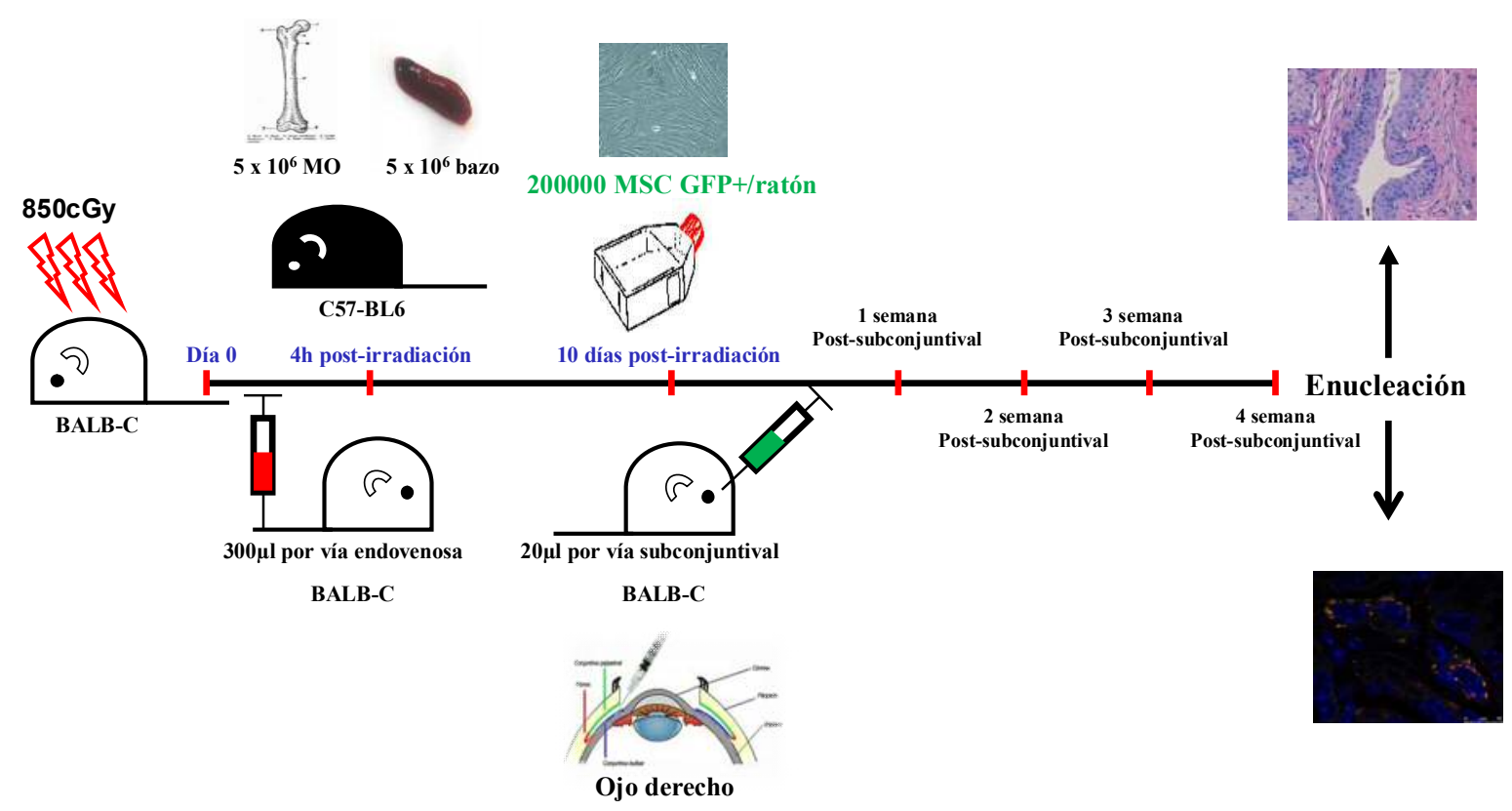

Fig. 27. Esquema cronológico del modelo murino de generación de ECRo. Trasplante de MO y esplenocitos.

\subsection{Animales con EICRo. Análisis clínico y anatomopatológico del párpado y de la glándula lagrimal}

\subsubsection{Signos clínicos de EICR y EICRo}

Los distintos signos clínicos de EICR y de EICRo se valoraron individualmente en cada ratón 2 veces a la semana hasta el día +40 postrasplante.

En la gráfica (Fig. 28) relativa al peso (A), se observa una disminución brusca de peso en ambos grupos siendo más intensa y precoz (a la semana aproximadamente) en

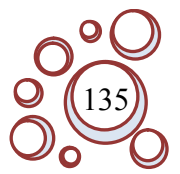


los ratones con EICR. En ambos casos, hay una posterior recuperación, siendo más discreta en la población con EICR, la cual además experimenta posteriormente una gran pérdida sostenida que se mantiene hasta el día 40 postrasplante, posiblemente por los trastornos digestivos asociados al cuadro de EICR (Fig. 28).

En las gráficas de postura (B), actividad (C), pelo (D) y piel (E) respectivamente (Fig.28) se hace muy evidente la diferencia entre los dos grupos de estudio. Mientras el grupo de la MO (control) se mantuvo estable a lo largo del periodo de seguimiento sin experimentar cambios, en el grupo de EICR se observó un deterioro progresivo. En el caso del parámetro referente al pelo $(D)$, entre el $5^{\circ}$ y $10^{\circ}$ día postrasplante, la población control experimenta un leve empeoramiento del cual se recupera al $15^{\circ}$ día aproximadamente debido al efecto de la radiación y de las células recibidas mediante el trasplante de MO (Fig. 28).

A la vista los resultados obtenidos podemos afirmar que la valoración de la EICR sistémica evidencia la existencia de cambios en los 5 rasgos clínicos de evaluación que facilitan la monitorización de la evolución de la EICR, siendo en todos los ratones la puntuación $\geq 1$ transcurridos 40 días del trasplante. Es decir, en todos los receptores a los que se les generó EICR se constató pérdida de peso, postura "encorvada", disminución de la actividad y alteración de la textura del pelo e integridad de la piel.

Los cambios clínicos oculares de los ratones con EICR se clasificaron teniendo en cuenta 3 grados de afectación clínica dependiendo de los signos macroscópicos observados en los ratones (Lorenzo y cols. ${ }^{224}$ ): blefarospasmo, pelo periocular, y borde palpebral. Todos los animales presentaron una puntuación $\geq 1$ en al menos uno de los ojos a los 40 días postrasplante. Estos signos clínicos oculares comenzaron a apreciarse transcurridos 10-15 días àroximadamente tras el trasplante con signos leves, como 
blefarospasmo o pequeñas alteraciones en el borde palpebral. A los 40 días del trasplante la afectación ocular se agravó apareciendo costras, heridas en el borde palpebral y alopecia.

En la última gráfica, se establecen las diferencias oculares entre el grupo control (MO) y el de EICR observándose un empeoramiento progresivo de los signos y síntomas oculares en el grupo EICR respecto al control, secundarios a los procesos propios de la patología subyacente (Fig. 28).

Las alteraciones macroscópicas oculares se correlacionan en el tiempo y en la magnitud de los síntomas con los signos sistémicos de EICR. Los animales fueron sacrificados a los 40 días del trasplante, e inmediatamente después se realizó la extracción de los párpados y la glándula lagrimal para el estudio histológico e inmunohistoquímico. 
A

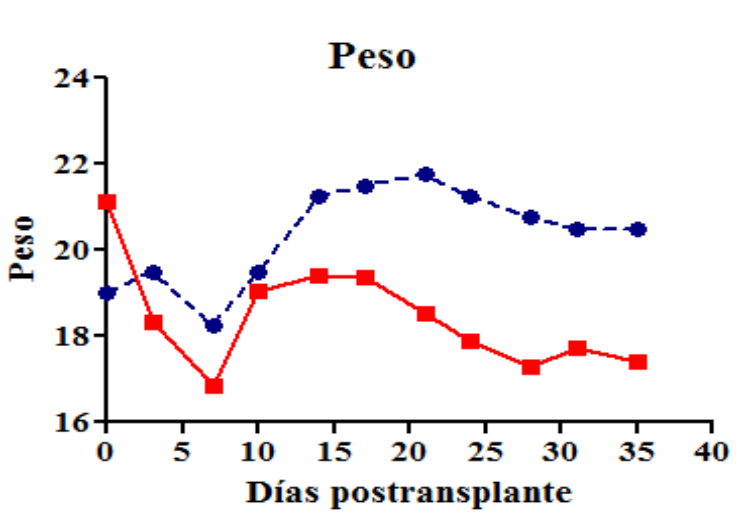

C

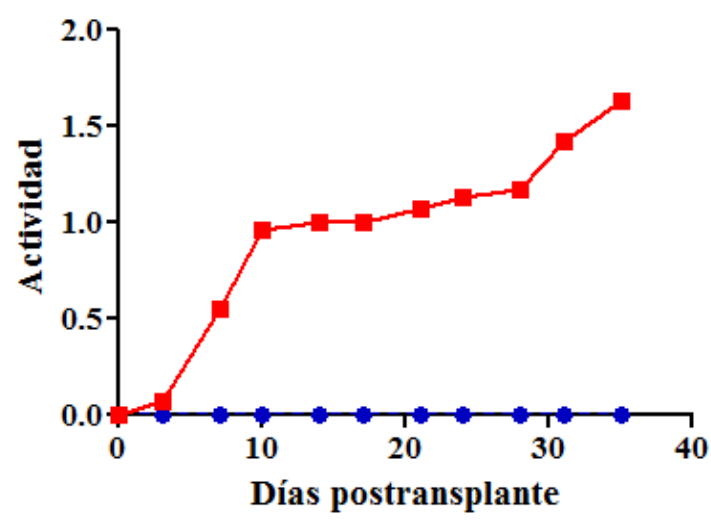

E

Piel

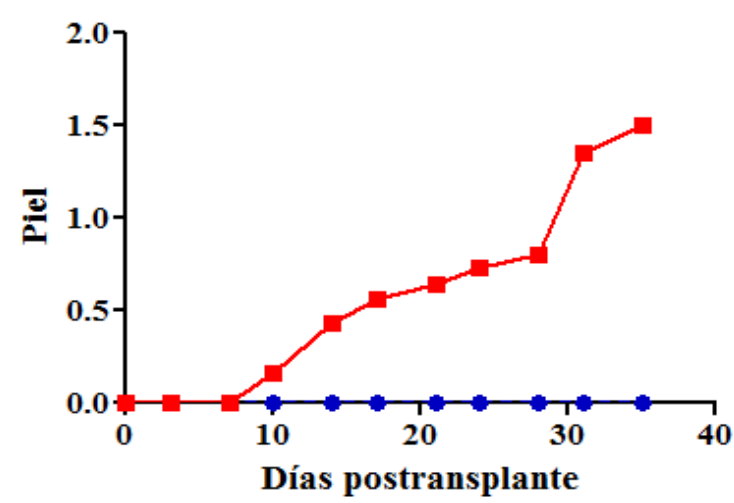

B

Postura

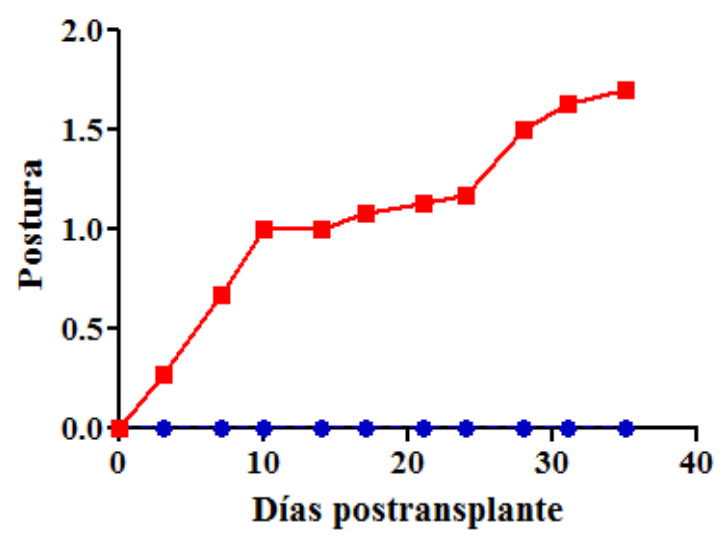

D Pelo

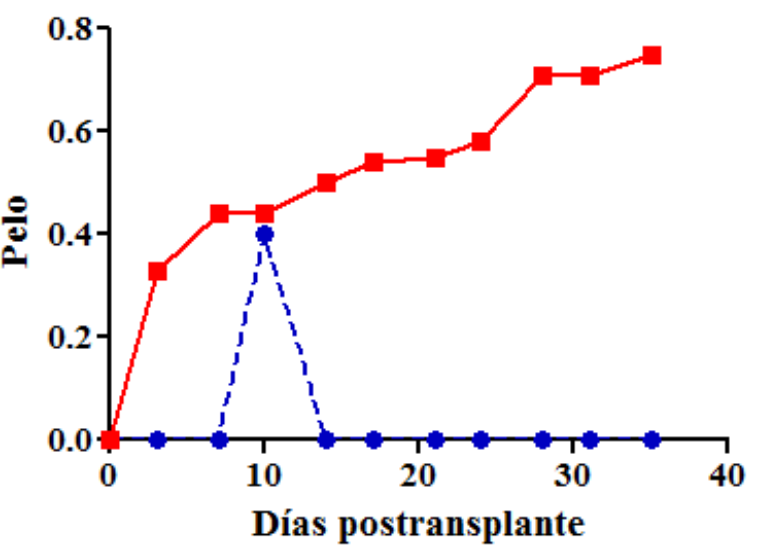

F

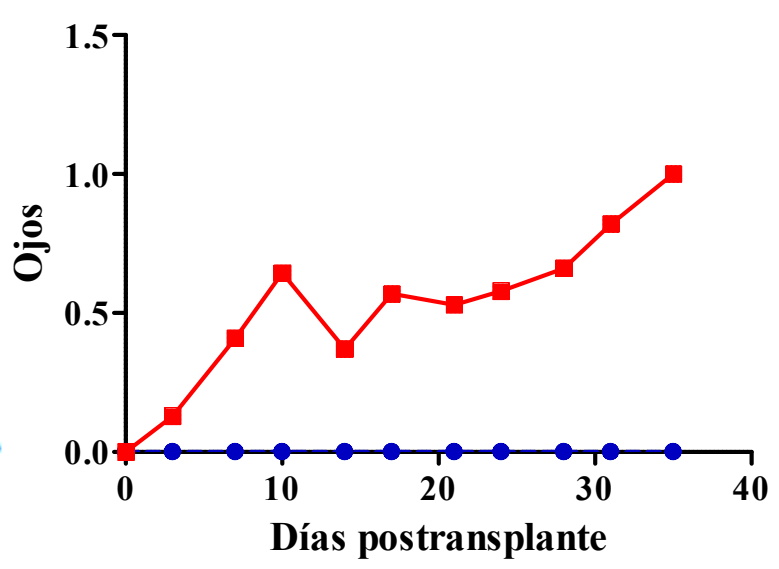

Fig. 28. Pérdida de peso (A), postura (B), actividad (C), integridad del pelo y de la piel (D y E) y afectación ocular (F). 


\subsubsection{Examen anatomopatológico de la superficie ocular en el}

\section{modelo de EICRo}

\subsubsection{Examen histológico mediante hematoxilina}

En el examen de las muestras procesadas y teñidas con hematoxilina-eosina y analizadas mediante microscopía óptica se apreciaron lesiones características de la EICR en todas las estructuras implicadas en este estudio, es decir, en la piel de los párpados, la conjuntiva tarsal y la glándula lagrimal. Las lesiones histológicas y fenómenos más frecuentemente observados mediante la tinción de hematoxilina- eosina en nuestras muestras son las siguientes:

1- Células y cuerpos apoptóticos. Se observaron de forma más frecuente como células aisladas aunque se localizaron ocasionalmente en pequeños grupos de células apoptóticas que se separaban de las células sanas vecinas, y que se rodeaban de un espacio claro (Fig. 30 C). Entre los cambios característicos de la apoptosis que se observaron en las muestras murinas estaban la condensación del citoplasma y cambios en la forma y el tamaño celular: las células que son redondas originalmente aparecen elongadas y, generalmente, más pequeñas. Otro cambio observado, el más característico de la apoptosis, fue la condensación de la cromatina nuclear y la presencia de cuerpos apoptóticos.

En nuestro trabajo, además de identificar estos cuerpos apoptóticos mediante hematosilina-eosina, confirmamos su existencia empleando el método de la Caspasa 3 (NovocastraTM Lyophilized Mouse Monoclonal Antibody CPP32) (Fig 32 B y C).

2.- Vacuolizacion citoplasmática: Se trata de un fenómeno que se caracteriza por la aparición de una o varias vacuolas desiguales en el citoplasma las cuales rechazan el núcleo hacia la periferia en las muestras sometidas a tinción con hematoxilina-eosina (Fig. 30 E y 31 D). 
3.- Satelitosis: En la EICR, se denomina así a la agrupación de linfocitos (células inflamatorias) que se localizan alrededor de células en proceso de apoptosis que se hallan de forma aislada y que se observan en las muestras teñidas con hematoxilinaeosina.

\section{4.- Infiltrado inflamatorio mononuclear linfocitario en capas basales $y$} suprabasales, perivascular y dispuesto en pequeños grupos.

En las muestras analizadas dentro de este trabajo, según la localización anatómica implicada, observamos lo siguiente:

En la región cutánea periocular, la principal característica observada ha sido la atrofia epidérmica acompañada de la presencia de infiltrados linfocitarios y cambios en los queratinocitos. Los infiltrados linfocitarios, se han observado en la dermis superficial y en la mayoría de los cortes se han encontrado linfocitos en la epidermis. Así mismo, existe una degeneración vacuolar localizada en las células basales epidérmicas. Es característica la observación de linfocitos alrededor de queratinocitos disqueratósicos o apoptóticos, lo que se ha definido con anterioridad como necrosis celular satélite o satelitosis, la cual hemos localizado en distintos cortes histológicos teñidos con hematosilina-eosina. En las formas más graves, aquellas que macroscópicamente presentaban una mayor afectación, se ha observado una correlación entre estas alteraciones y la existencia de hendiduras y espacios con la microscopia óptica que son el resultado de la separación de la unión dermoepidérmica y que aparecen secundariamente a los fenómenos de necrosis de queratinocitos.

En las muestras de glándula lagrimal, en el tejido conectivo se ha observado una alta densidad de fibras de colágeno y abundante número de células inflamatorias (Fig. 29 D y F), principalmente linfocitos y, en menor cantidad, células plasmáticas, dispuestas por todo el tejido conectivo, variando su número en función del grado de 
severidad de la enfermedad, llegando a formar densos acúmulos celulares. En los casos más graves se ha observado una intensa esclerosis interacinar. El calibre de los vasos capilares y de los linfáticos disminuyó de forma importante, encontrándose colapsados, hasta llegar al punto de observar una oclusión casi total de todos ellos. Los conductos excretores mostraron dilatación importante de su luz y estasis de su contenido estando revestidos por una capa de células epiteliales planas (Fig.29 D y F).

En la conjuntiva tarsal, se observó con frecuencia un proceso de metaplasia escamosa y disqueratosis conduciendo todo ello a la pérdida de epitelio conjuntival propio (Fig. 30 E). Otros fenómenos descritos con anterioridad que observamos son la satelitosis, la necrosis celular con cuerpos apoptóticos y la existencia de microvesiculas subepiteliales y células mononucleadas en la sustancia propia de la conjuntiva (Fig. 30 C y E).

Tras el examen histológico completo se pudo comprobar, que todos los ratones sometidos a una irradiación total y a los que posteriormente se les había inyectado células procedentes de medula ósea y del bazo mostraban alteraciones anatomopatológicas características de EICR ocular.

Ninguno de los hallazgos macroscópicos ni microscópicos descritos con anterioridad estaban presentes en los ratones control de nuestro modelo murino (Fig. 29 A,C y F. Fig. 30 A y D), por lo que descartamos que estos cambios histológicos estén causados por la irradiación, el estrés, ni ningún otro factor a los que son sometidos los ratones control, si no que, estos hallazgos parecen ser específicos y propios del proceso de la EICRo generado en el presente estudio. 


\section{- Examen histológico mediante hematoxilina-eosina de la glándula lagrimal}

Mediante la tinción hematoxilina-eosina se observaron los cambios anatomopatológicos y se establecieron diferencias estructurales en la glándula lagrimal de ratones $\mathrm{BALB} / \mathrm{c}$ entre el grupo control y el grupo al que se trasplantó y generó EICRo después de 4 semanas (Fig. 29).

\section{TEJIDO CONTROL}

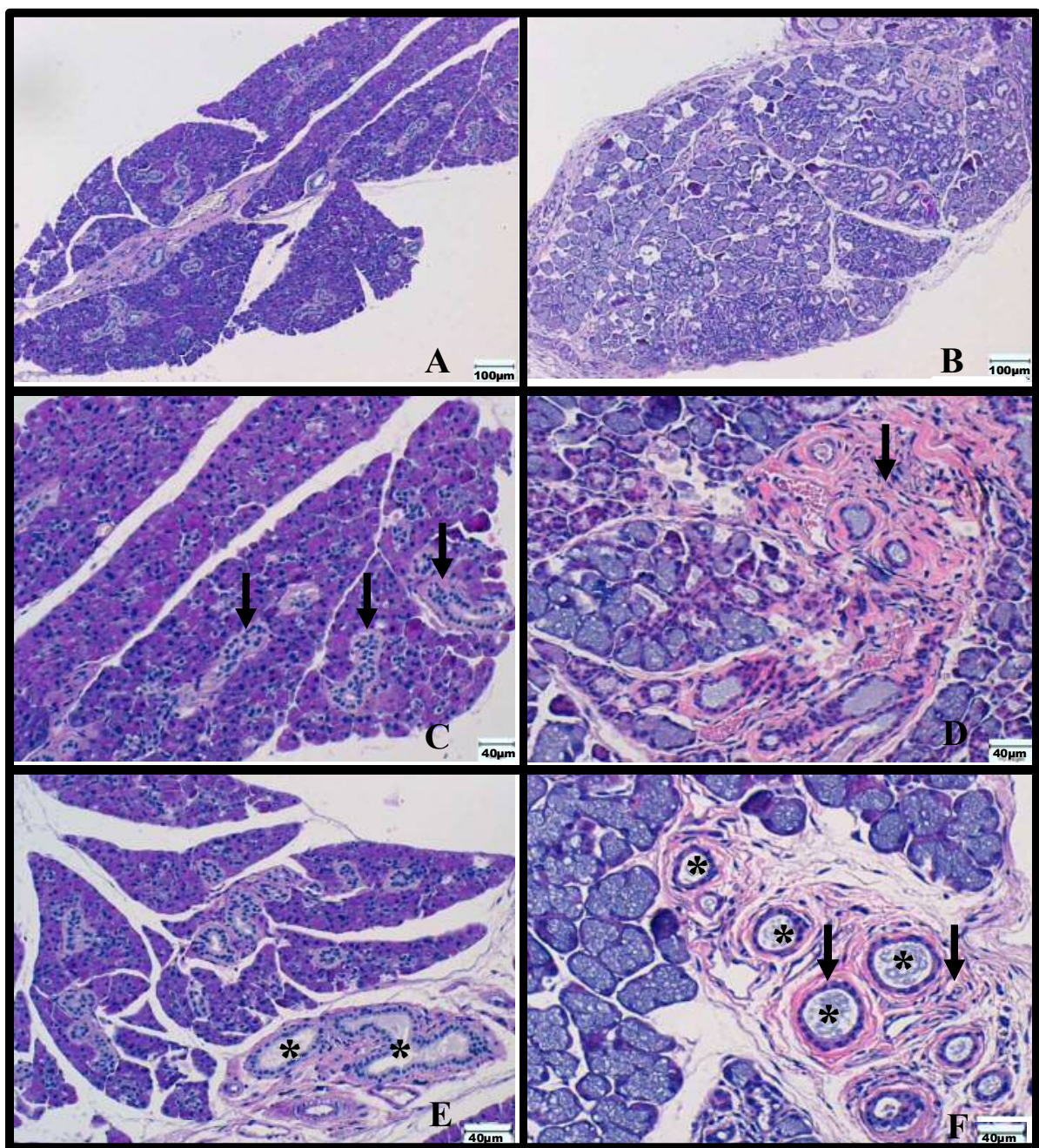

Fig. 29. A. Estructura anatomopatológica homogénea en ratón control. Magnificación x10. C. Detalle de los conductos secretores tapizados por epitelio monoestratificado cúbico (flechas). Magnificación x20. E. Colapso de la luz ductal (asteríscos) característica del tejido glandular lagrimal de los especímenes sanos. Magnificación x20. B. Cambios histológicos en el tejido glandular de ratón con EICRo. Magnificación x 10 D y F. Importante fibrosis alrededor de los conductos excretores acompañados de infiltrado inflamatorio (flechas). Magnificación x20. F. Detalle con microscopia óptica de la dilatación intraductal (asteriscos), revestimiento de los ductos por un epitelio plano monoestratificado, células mioepiteliales periductales y la existencia de componente inflamatorio difuso (flechas). Magnificación x 20.

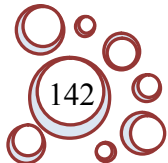




\section{-Examen histológico mediante hematoxilina-eosina del párpado}

Mediante la tinción hematoxilina-eosina se observaron los cambios anatomopatológicos y se establecieron diferencias estructurales a nivel de la conjuntiva tarsal en ratones $\mathrm{BALB} / \mathrm{c}$ entre el grupo control y el grupo al que se trasplantó y gerneró EICRo después de 4 semanas. Se evidenció la aparición de metaplasia escamosa, alteración en el volumen de células caliciformes conjuntivales, la presencia de cuerpos apoptóticos y la vacuolización de los estratos basales del epitelio conjuntival en el grupo de ratones BALB/c que desarrolló EICRo (Fig. 30).

TEJIDO CONTROL

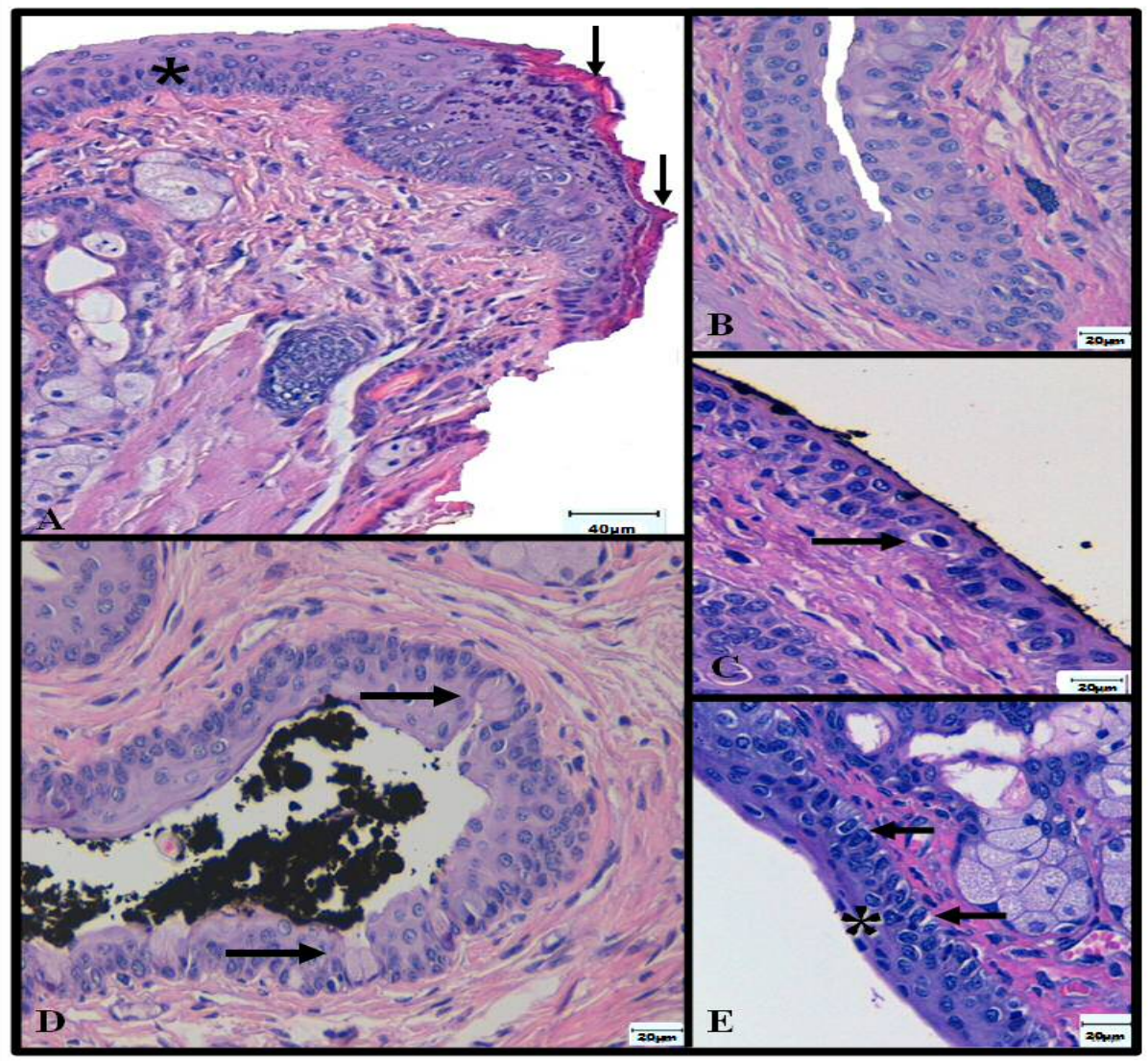

Fig. 30. A. Detalle con microscopia óptica del borde libre palpebral, a nivel de la unión mucocutánea en ratón control. Se observa la sustitución progresiva de las células de la piel que muestran queratinización en los estratos superficiales (flechas) por células cúbicas y columnares que constituyen el epitelio poliestratificado de la conjuntiva bulbar (asterísco). Magnificación x20. D. Secreción mucosa por parte de las células secretoras del epitelio conjuntival en ratón control (flechas). Magnificación x40. B. Secreción mucosa aislada en conjuntiva de ratón con EICRo. Magnificación x40. C. Detalle de cuerpo apoptótico en conjuntiva tarsal de ratón con EICRo (flecha). Magnificación x40. E. Metaplasia escamosa en conjuntiva tarsal (asterisco). Se observan cuerpos apoptóticos y vacuolización de los estratos basales del epitelio conjuntival (flechas). Magnificación x40. 


\subsubsection{Examen histológico mediante PAS-azul alcian del párpado}

La tinción PAS pone de manifiesto la secreción que ejercen las células caliciformes conjuntivales de polisacáridos simples, mucoproteínas y mucopolisacáridos neutros que participan en la formación de la capa mucosa de la película lagrimal. Una característica de la EICRo es la depleción de células caliciformes a nivel palpebral que se comprobó en los ratones a los que generó EICRo al observar una disminución en la tinción de PAS en la conjuntiva tarsal murina tras 4 semanas al compararlo con el tejido control (Fig. 31).

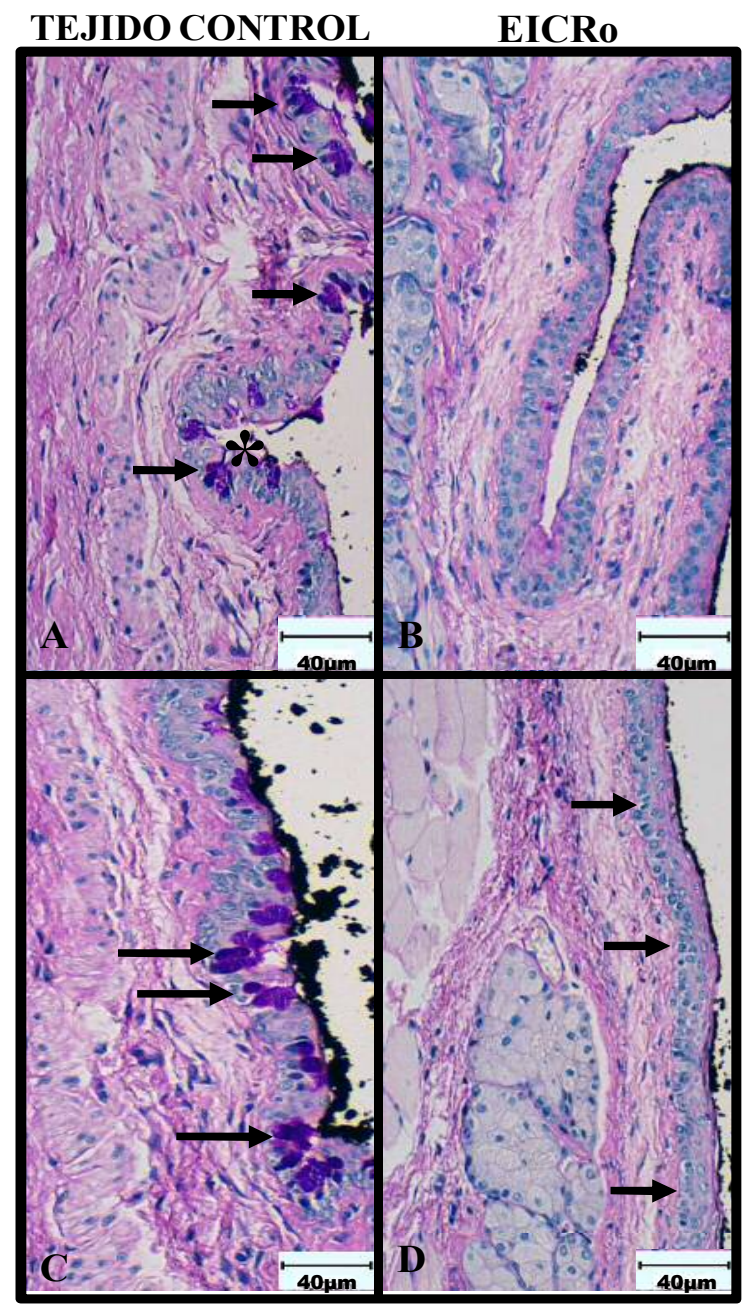

Fig. 31. Detalle con microscopio óptico del producto PAS positivo correspondiente a mucopolisacáridos elaborados por las células caliciformes de la conjuntiva tarsal de ratones controles sanos. A y C Abundante material de secreción PAS positivo en conjuntiva tarsal (flechas) de ratones control. En A se observan las criptas de Henle propias del tejido conjuntival secretor sano (asterisco). Magnificación x20. B y D. Ausencia de material PAS positivo en epitelio conjuntival en ratones con EICRo. Se observa la ausencia de las criptas típicas. Estos fenómenos se acompañan de procesos de metaplasia escamosa y vacuolización en capas basales del epitelio conjuntival (flechas). Magnificación x20. 


\subsubsection{Examen histológico de la conjuntiva tarsal mediante caspasas 3}

Mediante la tinción inmunohistoquímica con el anticuerpo anticasapasas 3 observamos la presencia de los cuerpos apoptóticos típicos de los estratos basales del epitelio conjuntival de los ratones con EICRo (Fig. 32).

TEJIDO CONTROL

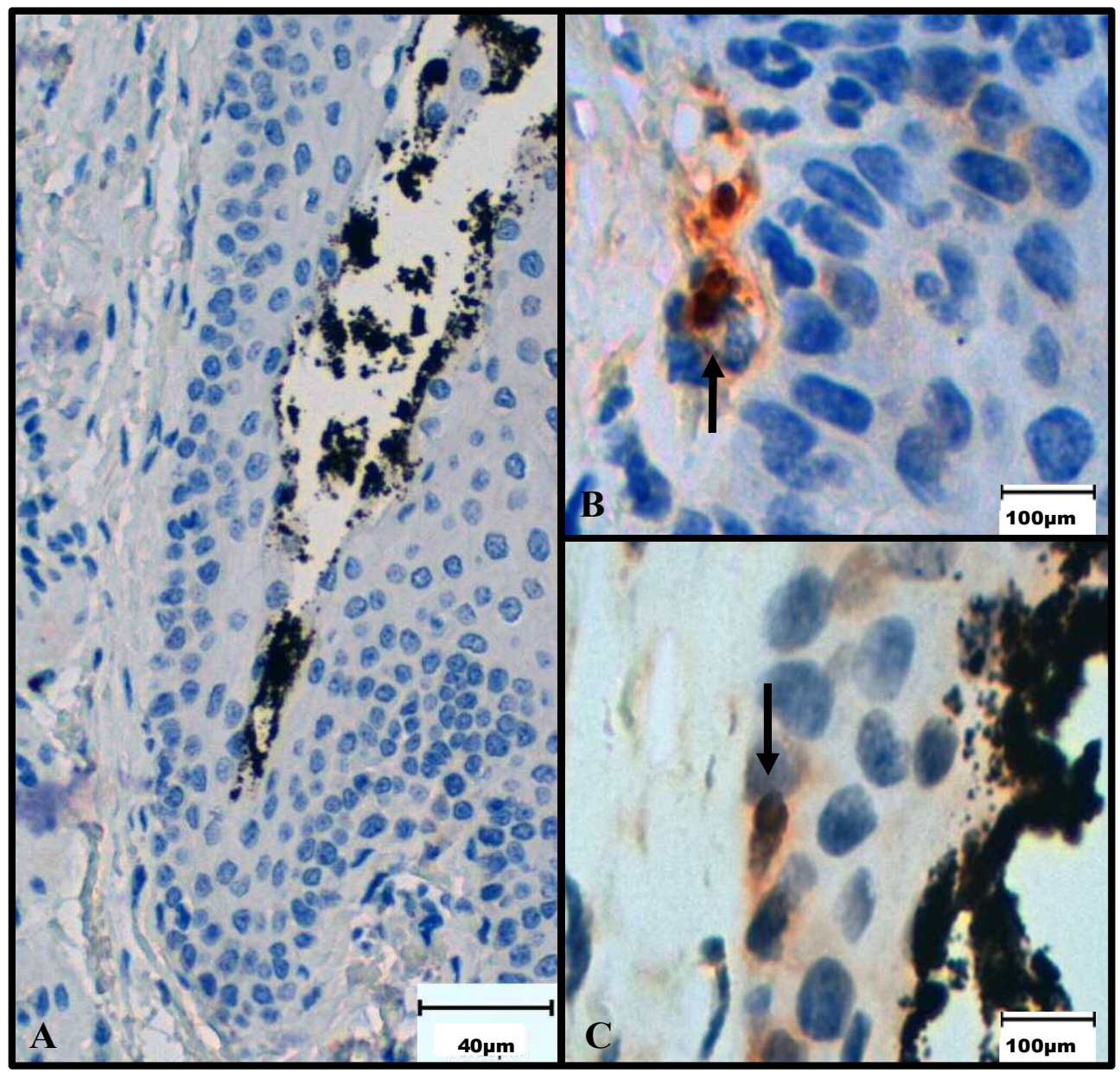

Fig. 32. A. Ausencia de tinción con Caspasa 3 en conjuntiva tarsal de ratón control. Magnificación x20. B y C. Tinción con Caspasa 3 de cuerpos apoptóticos en conjuntiva tarsal 38 días después de la generación de EICRo. Magnificación x100. 


\subsubsection{Examen histológico mediante citología de impresión conjuntival}

La citología de impresión permite recoger las capas más superficiales del epitelio corneo-conjuntival permitiendo conocer la interacción que existen entre las células epiteliales y otros componentes como las células caliciformes las cuales, se hallan deplecionadas en la EICRo (Fig. 33).

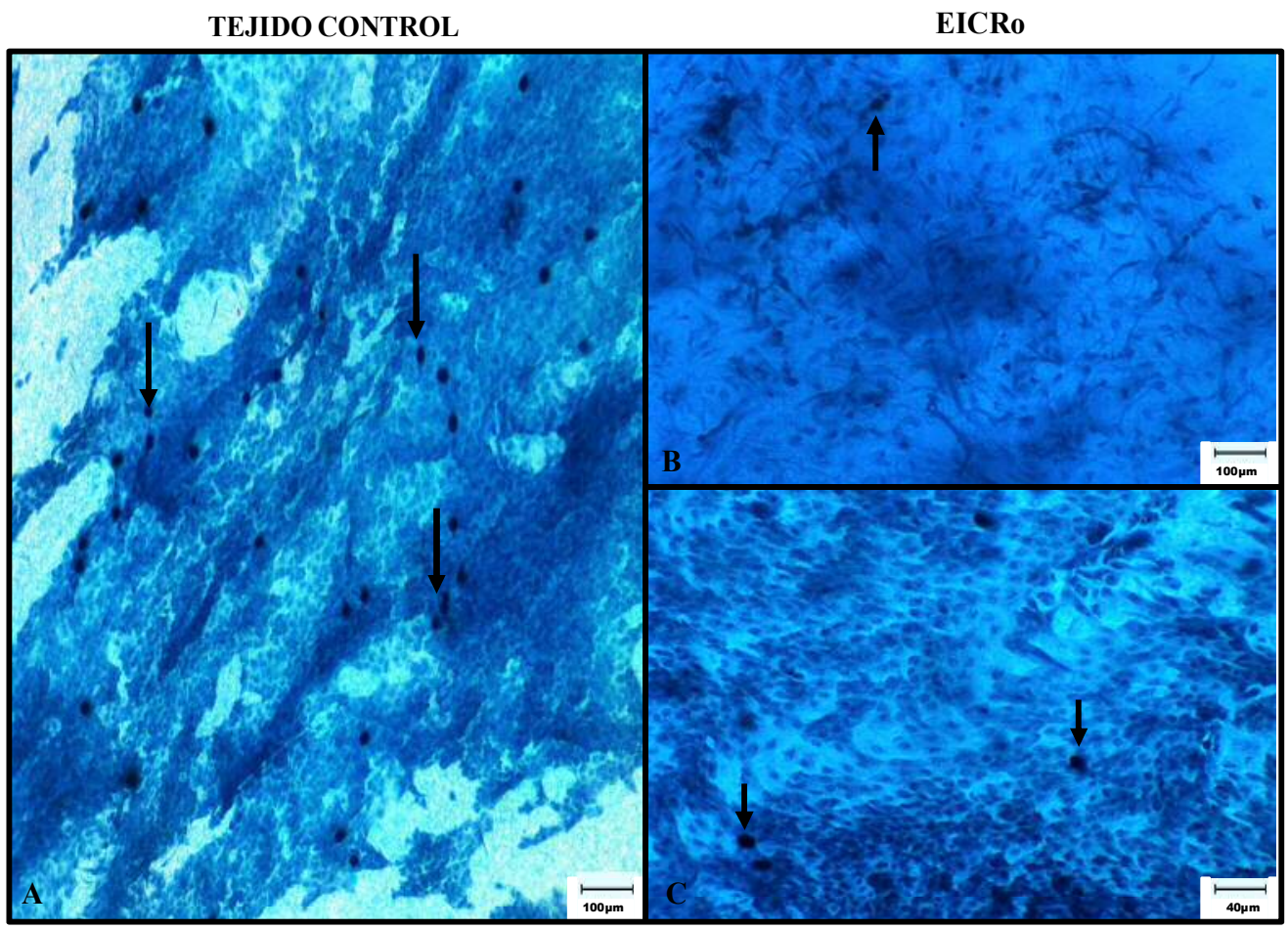

Fig. 33. A. Detalle de células caliciformes en técnica de citología de impresión conjuntival en ratón sano (flechas). Las células epiteliales presentes muestran bordes bien definidos Magnificación x10. B Escasa presencia de células caliciformes en citología de impresión de ratón con EICRo (flecha) 38 días después de la generación de EICRo. Magnificación x 10. C Citología de impresión de ratón con EICRo. Además del escaso volumen de células caliciformes (flechas), se observan células epiteliales grandes y poligonales con bordes mínimamente definidos. Magnificación x20. 


\subsection{Análisis de las variaciones en la producción de lágrima}

El análisis de la lágrima mostró una reducción significativa del volumen en los ratones en los que se generó EICRo $(2,30 \mathrm{~mm} \pm 0,79)$ frente a los que solo fueron trasplantados con MO (2,88mm $\pm 0,7)$ (Fig. 34).

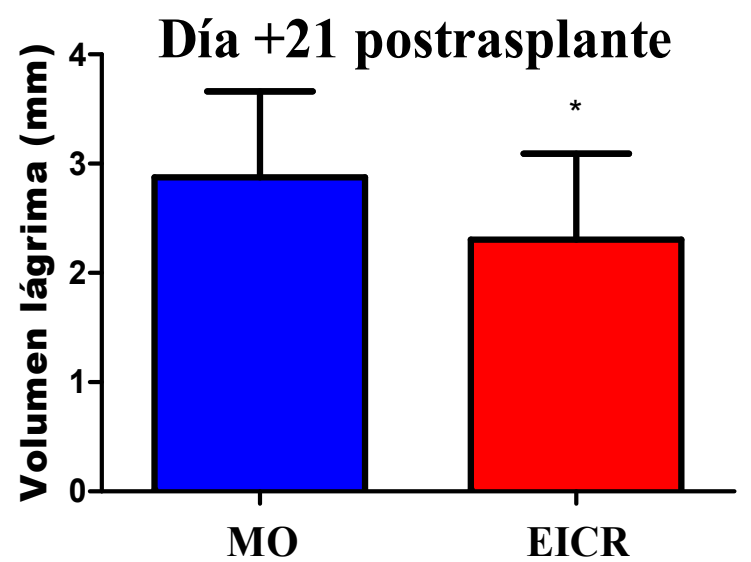

\begin{tabular}{|c|c|c|c|}
\hline & MO $(\mathbf{N}=\mathbf{2 2})$ & EICR $(\mathbf{N}=18)$ & P \\
\hline Volumen $(\mathbf{m m})$ & $2,88 \pm 0,78$ & $2,30 \pm 0,79$ & $\mathbf{P}=\mathbf{0 , 0 3 0}(<0,05 *)$ \\
\hline
\end{tabular}

Fig. 34. Diferencias entre el volumen lagrimal de la población del grupo MO frente al grupo EICR. 


\subsection{Osmolaridad de la película lagrimal}

En el grupo de ratones a los que se generó EICRo y en relación al grupo control, el análisis de la lágrima mediante el empleo de un osmolarímetro de TerLab mostró un aumento de la osmolaridad y de la salinidad de la lágrima (EICR $353 \mathrm{mOsm} / \mathrm{L} \pm 20$, MO $326 \mathrm{mOsm} / \mathrm{L} \pm 19$ ). Este resultado sugiere la presencia de síndrome de ojo seco secundario a EICR (Fig. 35).

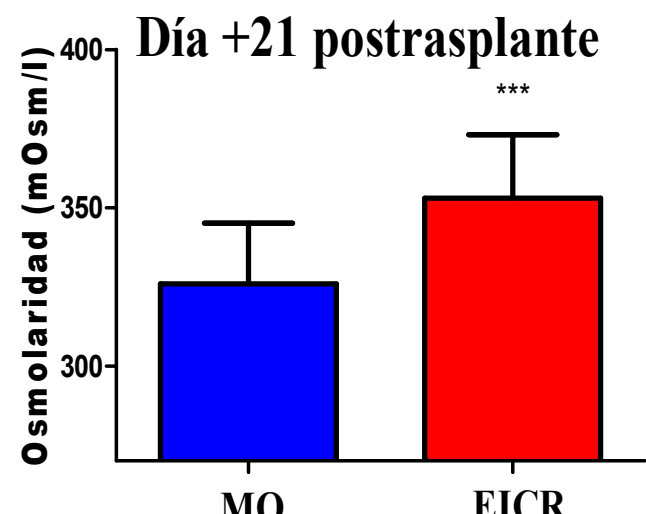

\begin{tabular}{|c|c|c|c|}
\hline & MO $(\mathbf{N}=22)$ & EICR $(\mathbf{N}=18)$ & P \\
\hline Osmolaridad $(\mathrm{mOsm} / \mathrm{l})$ & $326 \pm 19$ & $353 \pm 20$ & $\mathrm{P}<0,001(* * *)$ \\
\hline
\end{tabular}

Fig. 35. Diferencias entre la osmolaridad lagrimal del grupo MO y del grupo EICR. 


\subsection{Transducción de las CSM}

La eficiencia de la transducción mediante CMF evaluando la expresión de GFP a las 72 horas tras la transducción alcanzó valores próximos al 50\% en todos los casos.

- Seguimiento celular tras la administración subconjuntival y control de la distribución de las CSM mediante bioluminiscencia

Las células transducidas se administraron por vía subconjuntical 10 días después del trasplante y la generación de la EICRo en los ratones BALB/c. Los primeros días postinfusión la monitorización de la bioluminiscencia se saturaba en los ratones $\mathrm{BALB} / \mathrm{c}$ en las mediciones que se hicieron en el Xenogen IVIS 50 Bioluminescence Imaging System. Posteriormente, la señal de la monitorización de la bioluminiscencia fue descendiendo progresivamente (Fig. 36). Se consiguió detectar bioluminiscencia en los ojos de los ratones BALB/c durante las 5 semanas posteriores a la administración subconjuntival de las hCSM transducidas. Para el análisis se determinaron las regiones de interés (ROI) basadas en el contorno de las mismas y calculando para cada una de ellas la emisión de fotones/segundo. La detección de la emisión de bioluminiscencia se realizó una vez a la semana durante 5 semanas (Fig. 37, 38 y 39). 


\section{BIOLUMINISCENCIA DEL OD DE UN RATON CON EICRo}

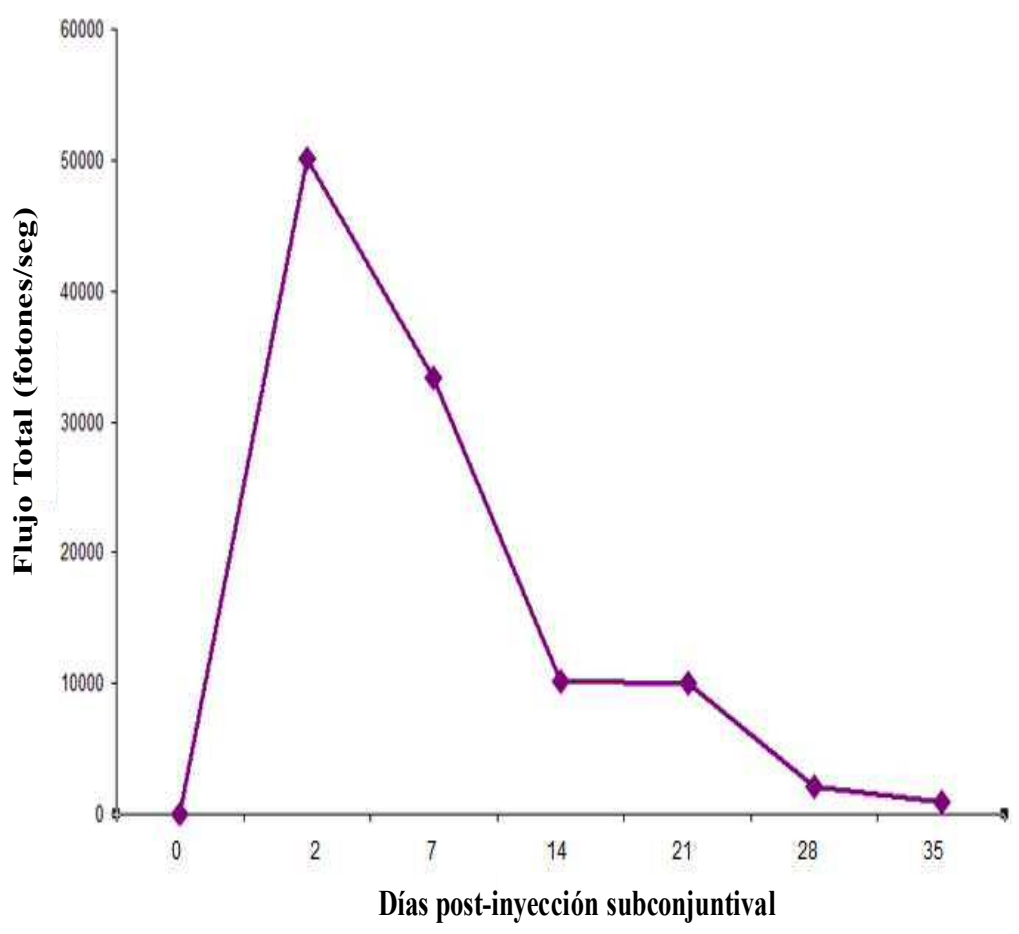

Fig. 36. Ejemplo de la evolución del flujo total (fotones/segundo) del ojo derecho de un ratón con EICRo después de la inyección subconjuntival de 200000 CSM transducidas durante 5 semanas. 

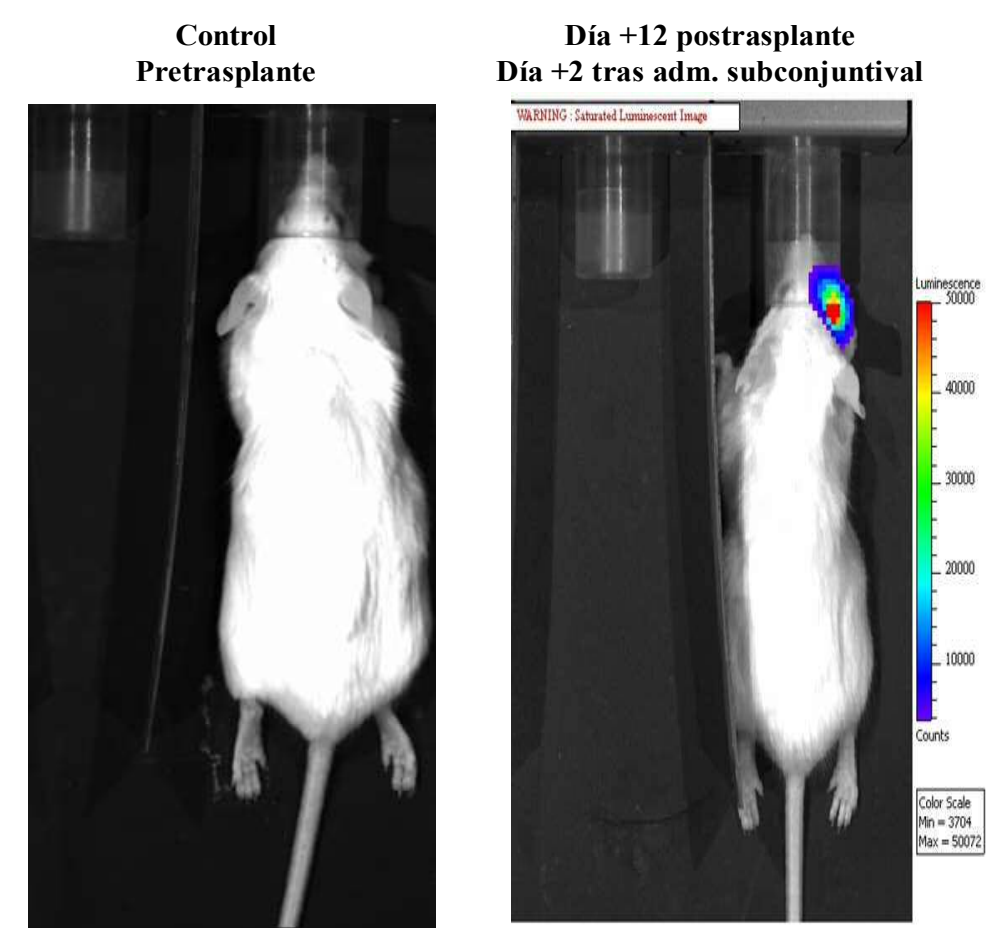

Día +17 postrasplante

Día +7 tras adm. subconjuntival

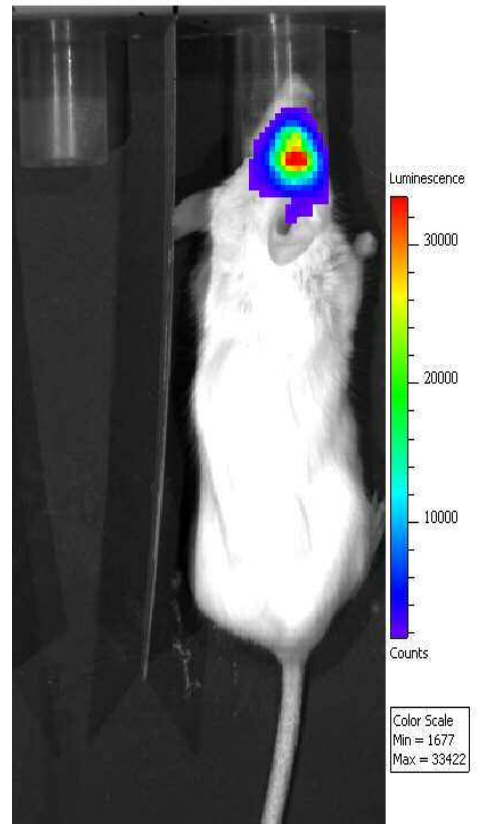

Fig. 37. Imágenes representativas de la emisión de fotones en el control pretrasplante y tras 2 y 7 días de la administración de CSM por vía subconjuntival, transcurridos 10 días de la generación de la EICRo.

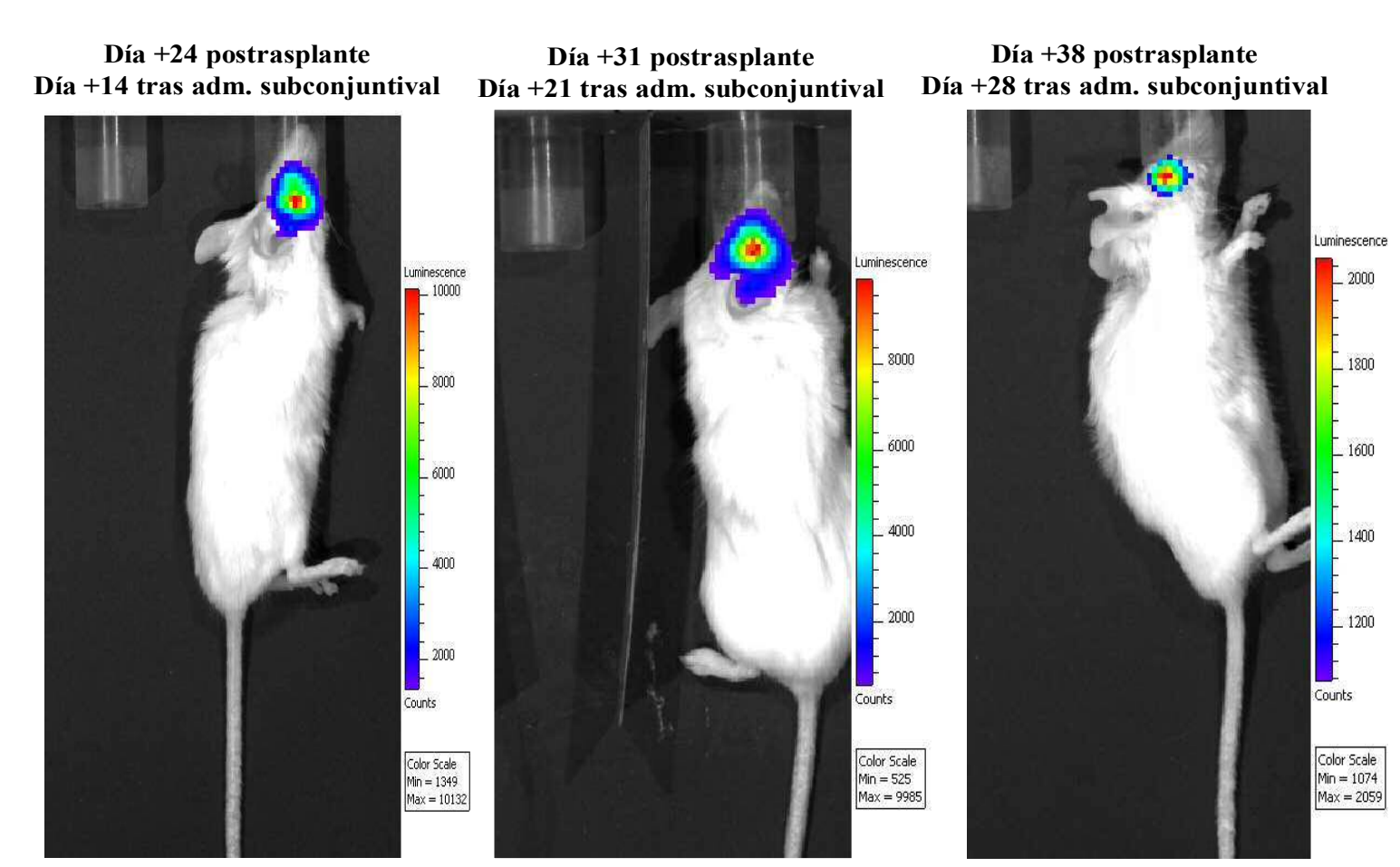

Fig. 38. Imágenes representativas de la emisión de fotones tras 14, 21 y 28 días de la administración de CSM por vía subconjuntival, transcurridos 10 días de la generación de la EICRo. 
Dia +45 postrasplante

Día +35 tras adm. subconjuntival

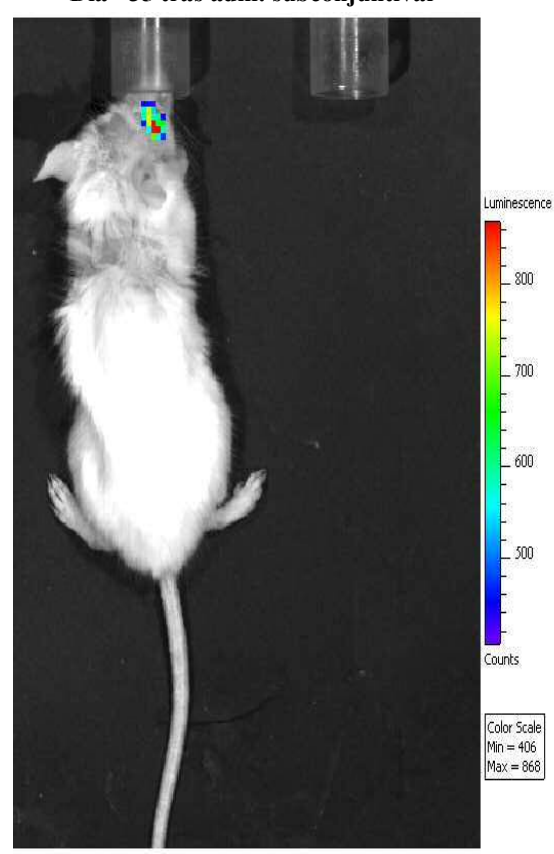

Fig. 39. Imagen representativa de la emisión de fotones tras 35 días de la administración de CSM por vía subconjuntival, transcurridos 10 días de la generación de la EICRo.

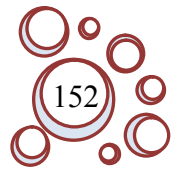




\subsection{Animales control tratados con inyección subconjuntival de}

\section{CSM. Análisis Inmunohistoquímico de la glándula lagrimal y}

\section{del párpado}

\subsubsection{Análisis Inmunohistoquímico de la glándula lagrimal control}

La inmunoflorescencia para GFP+y mitocondria humana permite conocer si existe presencia de hCSM en las muestras. La ausencia de estos marcadores y la presencia exclusiva de DAPI en los núcleos de las células de la glándula lagrimal de los ratones BALB/c control nos permite confirmar la ausencia de reacciones inespecíficas (Fig.40).

\section{GLÁNDULA LAGRIMAL CONTROL}

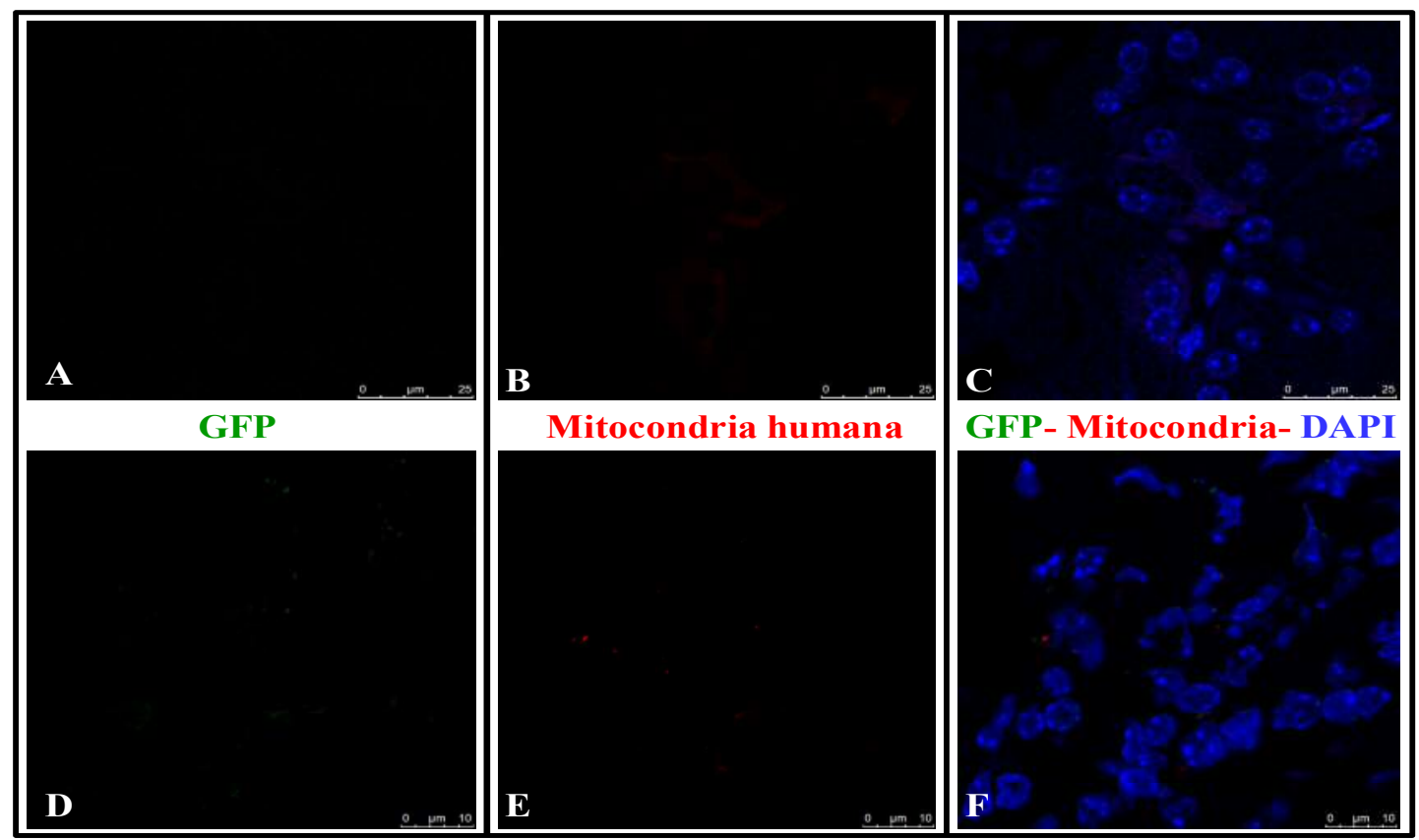

Fig. 40. Inmunofluorescencia para GFP y Mitocondria humana. Muestras de glándula lagrimal de ratones control. A y D: Inmunofluorescencia para GFP que marca las CSM prácticamente imperceptible. B y E: Ausencia de marcaje inmunofluorescente para Mitocondria humana que también marca las CSM. C y F: Combinación de ambas tinciones $\left(\mathrm{GFP}^{+}\right.$y Mitocondria humana $\left.{ }^{+}\right)$, y de la tinción azul que corresponde a DAPI, que marca los núcleos de las células que forman parte de la glándula lagrimal murina que en este caso es la dominante y más evidente. 


\subsubsection{Análisis Inmunohistoquímico del párpado control}

Los resultados observados son análogos a los obtenidos a nivel de la glándula

lagrimal pero en este caso, en estructura palpebral (Fig.41).

PÁRPADO CONTROL

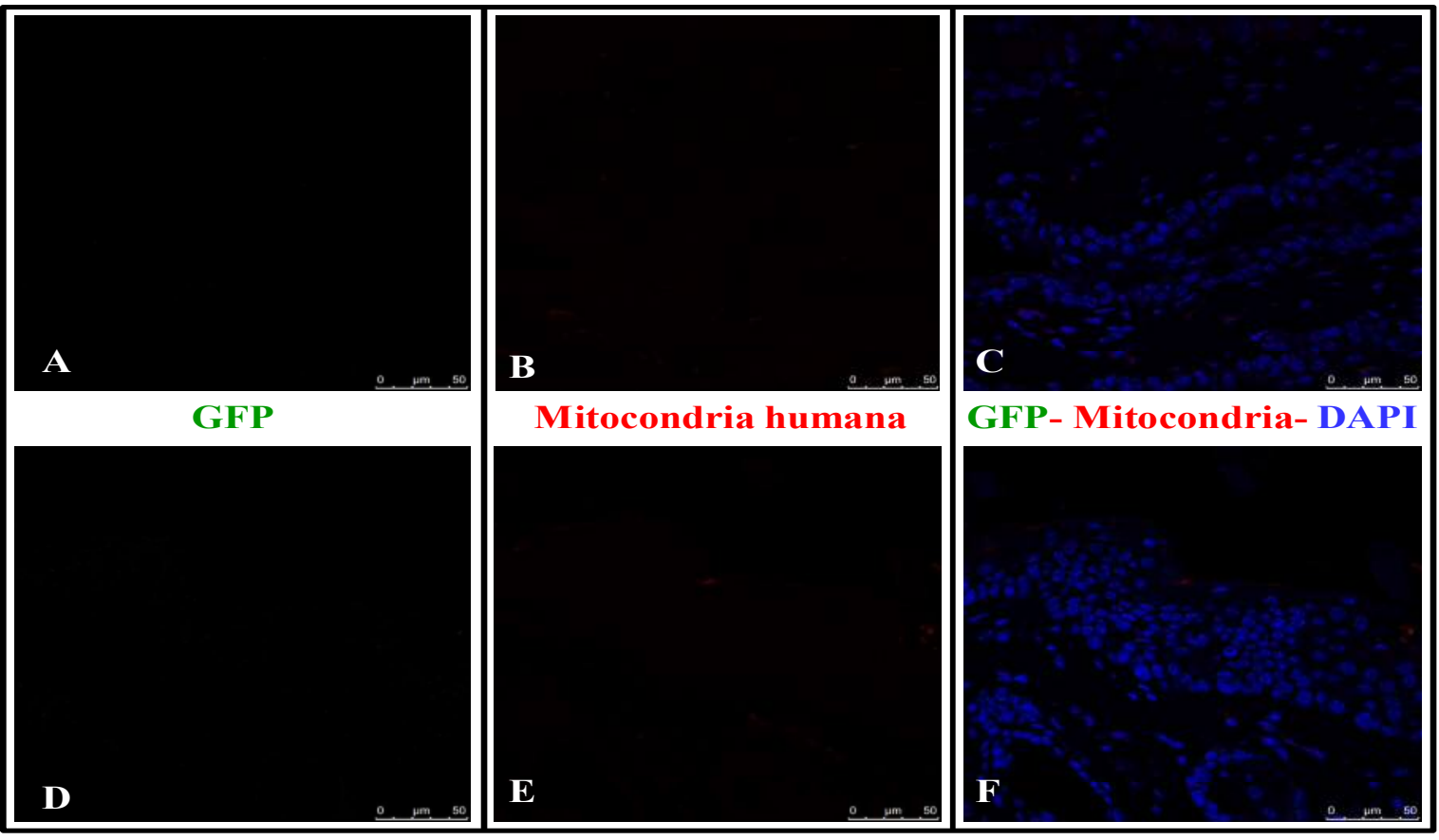

Fig. 41. Inmunofluorescencia para GFP y Mitocondria humana. Muestras de párpado de ratones control. A y D: Inmunofluorescencia para GFP+ nula. B y E: Marcaje inmunofluorescente para Mitocondria humana que marca las CSM ausente $\mathbf{C}$ y F: Combinación de ambas tinciones ( $\mathrm{GFP}^{+}$y Mitocondria humana + ), y DAPI que marca los núcleos celulares. Solo la tinción DAPI es positiva en este caso. 


\subsection{Animales con EICRo tratados con inyección subconjuntival}

\section{de CSM. Análisis Inmunohistoquímico de la glándula lagrimal y}

\section{del párpado}

\subsubsection{Análisis Inmunohistoquímico de la presencia de células GFP ${ }^{+}$}

\section{inyectadas subconjuntivalmente en glándula lagrimal de ratones con EICRo}

El doble marcaje para GFP y Mitocondria humana en el análisis inmunohistoquímico de las muestras de glándula lagrimal de animales con EICRo, pone de manifiesto la presencia de hCSM GFP ${ }^{+}$después de 4 semanas de su administración por vía subconjuntival (Fig. 42).

\section{GLANDULA LAGRIMAL CON EICRo}

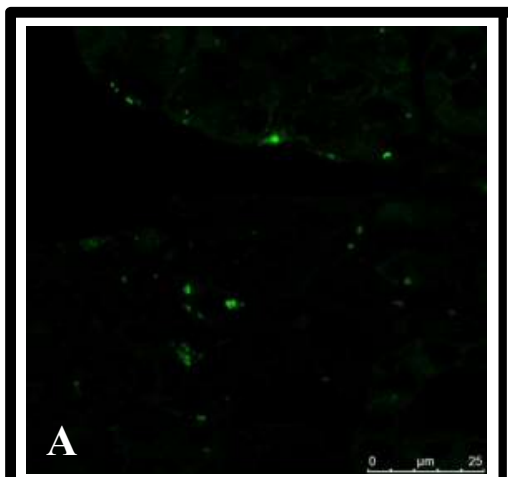

GFP

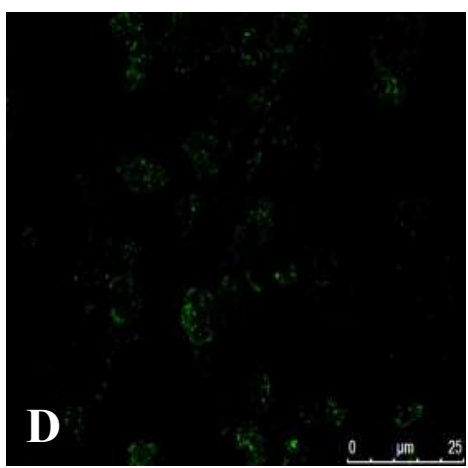

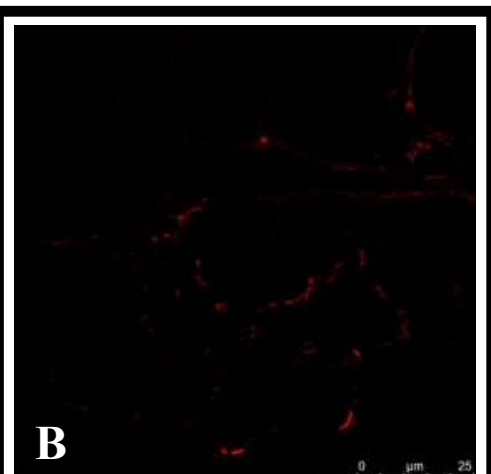

Mitocondria humana

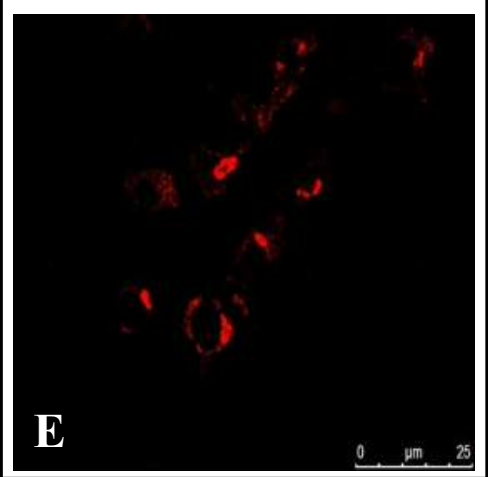

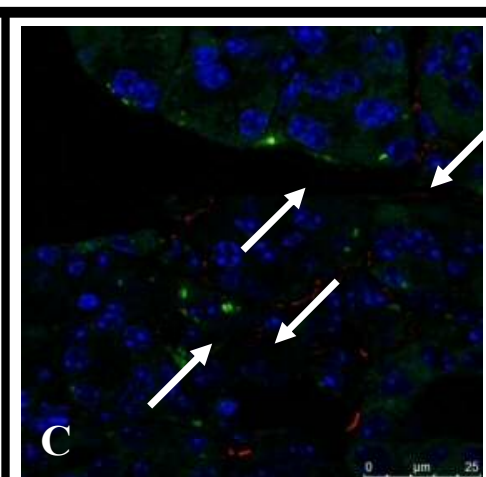

GFP-Mitocondria-DAPI

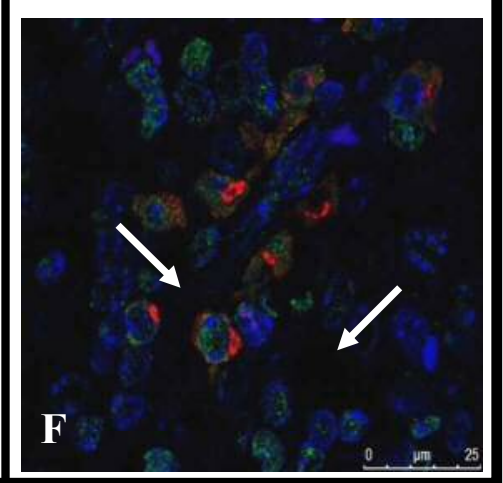

Fig. 42. Inmunofluorescencia para GFP y Mitocondria humana. Muestras de glándula lagrimal de ratones con EICRo procesadas después de 4 semanas días post-inyección. A y D: Inmunofluorescencia para GFP que marca las CSM. B y E: Marcaje inmunofluorescente para Mitocondria humana que también marca las CSM. C y F: Combinación de ambas tinciones $\left(\mathrm{GFP}^{+}\right.$y Mitocondria humana + ), y de la tinción azul que corresponde a DAPI, que marca los núcleos de las células que forman parte de la glándula lagrimal murina. Las flechas indican en todas las imágenes CSM. 


\subsubsection{Análisis Inmunohistoquímico de la presencia de células GFP ${ }^{+}$}

\section{inyectadas subconjuntivalmente en el párpado de ratones con EICRo}

También logramos identificar a nivel palpebral hCSM $\mathrm{GFP}^{+}$trascurridas 4 semanas de su administración por vía subconjuntival en ratones con EICRo (Fig. 43).

\section{PARPADO CON EICRO}

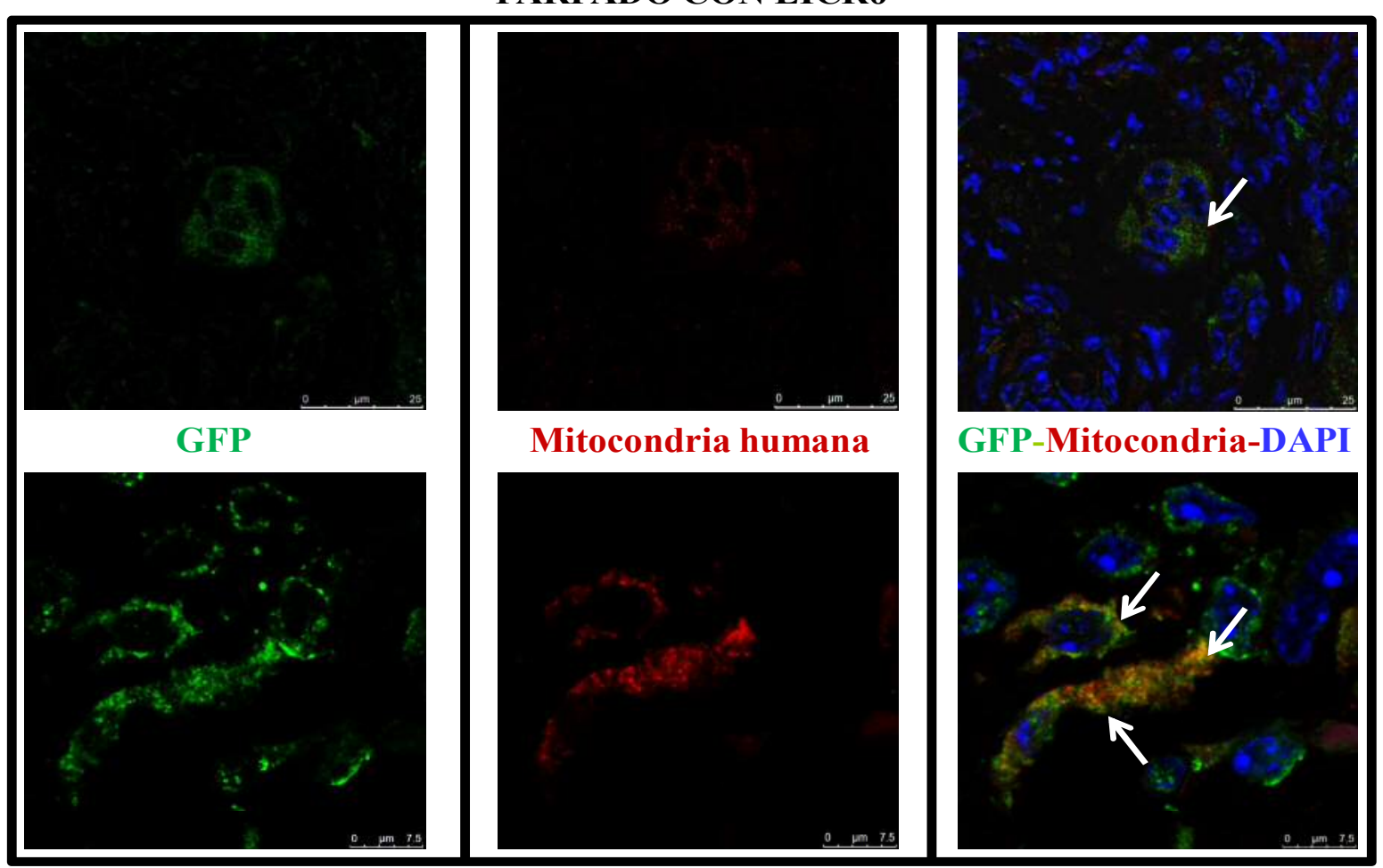

Fig. 43. Inmunofluorescencia para GFP y Mitocondria humana. Muestras de párpado de ratones con EICRo después de 4 semanas de su administración subconjuntival. A y D: Inmunofluorescencia para GFP+. B y E: Marcaje inmunofluorescente para Mitocondria humana que marca las hCSM. C y F: Combinación de ambas tinciones $\left(\mathrm{GFP}^{+}\right.$y Mitocondria humana $\left.{ }^{+}\right)$, y DAPI que marca los núcleos de las células palpebrales de las muestras de ratones afectados de EICRo. Las flechas indican hCSM. 


\subsection{Análisis de la infiltración de etiología inflamatoria en la}

\section{glándula lagrimal de la población afectada por EICR mediante}

\section{citometría de flujo}

El examen histológico de los párpados y de la glándula lagrimal de los ratones $\mathrm{BALB} / \mathrm{c}$ trasplantados con células procedentes de la $\mathrm{MO}$ y esplenocitos de ratones C57BL/6 reveló la existencia de infiltración linfocitaria inflamatoria. Por este motivo, decidimos procesar y analizar transcurridas 4 semanas de la administración subconjuntival de $2 \times 10^{5}$ hCSM en el OD las muestras de glándula lagrimal del OI no tratado como del OD tratado de los ratones BALB/c con EICRo con el fin de confirmar la presencia linfocitos $\mathrm{T}$ procedentes de ratones donantes $\mathrm{C} 57 \mathrm{BL} / 6$ (población $\left.\mathrm{CD}^{+} / \mathrm{CD} 45^{+} / \mathrm{H} 2 \mathrm{D}^{\mathrm{b}+}\right)$.

En la Fig. 44 se puede observar la presencia de la población $\mathrm{CD} 3+/ \mathrm{CD} 45+/ \mathrm{H}_{2} \mathrm{D}^{\mathrm{b}+}$ en la glándula lagrimal de todos los ratones a los que se les generó EICR. Empleamos como control muestras de glándulas lagrimales de ambos ojos de ratones control a los que no se generó EICR.

En los animales con EICRo que fueron tratados por vía subconjuntival en el OD con hCSM transducidas se comprobó la presencia de estas células mediante bioluminiscencia durante un periodo de seguimiento de 5 semanas. Además, mediante inmunohistoquímica se verificó la presencia de células $\mathrm{GFP}^{+}$y mitocondria humana ${ }^{+} \mathrm{a}$ los 30 días de su administración subconjuntival. Asimismo, pudimos observar una significativa disminución del porcentaje de infiltración linfoide glandular de la población $\mathrm{CD}^{+} / \mathrm{CD} 45^{+} / \mathrm{H} 2 \mathrm{D}^{\mathrm{b}+}$ en el OD de los ratones BALB/c con EICRo tratados por vía subconjuntival con hCSM.

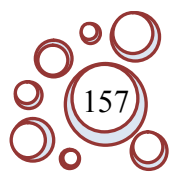


INFILTRACIÓN LINFOCITARIA DE LA GLÁNDULA LAGRIMAL

EN EL OJO IZQUIERDO DE RATONES CON EICH
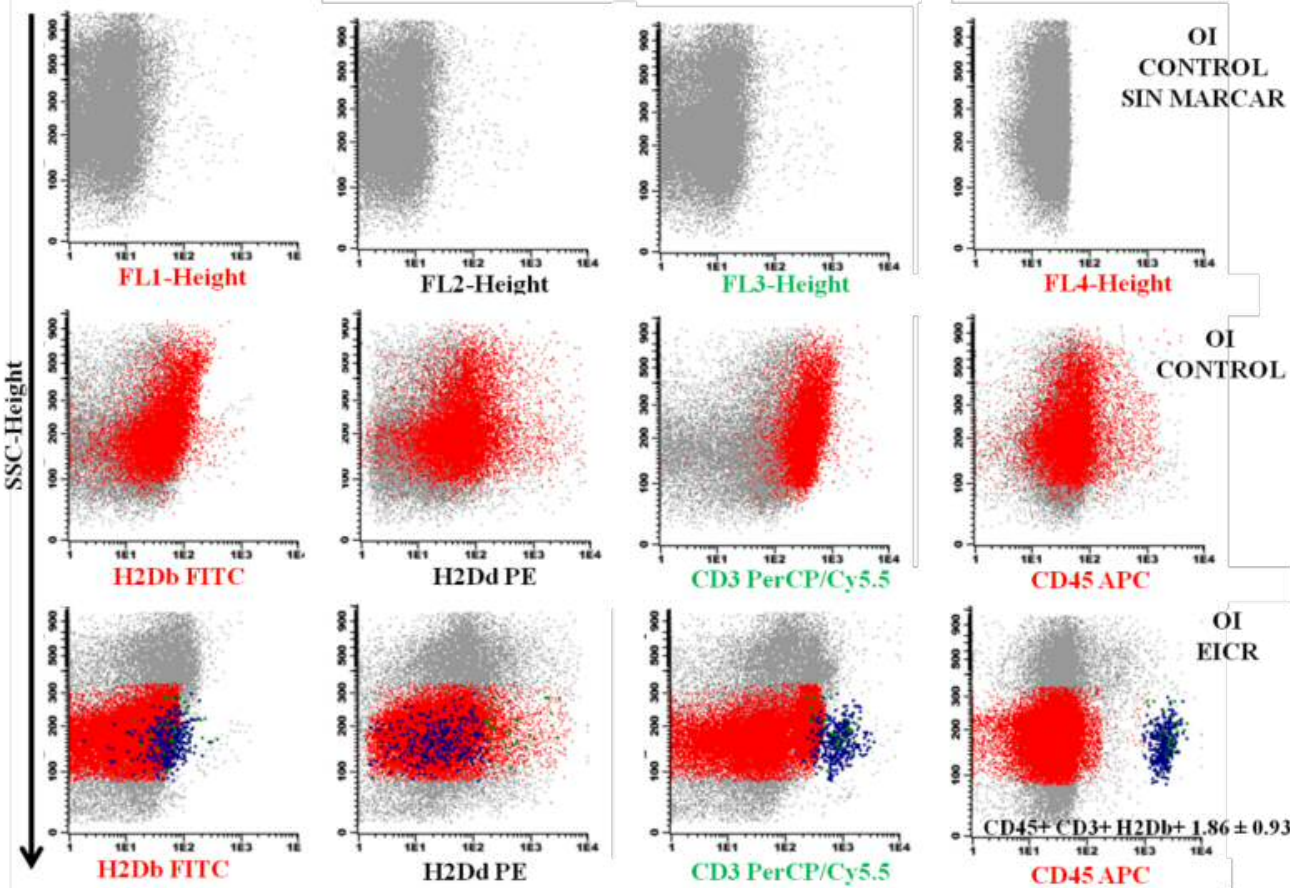

INFILTRACIÓN LINFOCITARIADE LA GLÁNDULA LAGRIMAL EN EL OJO DERECHO DE RATONES CON EICH
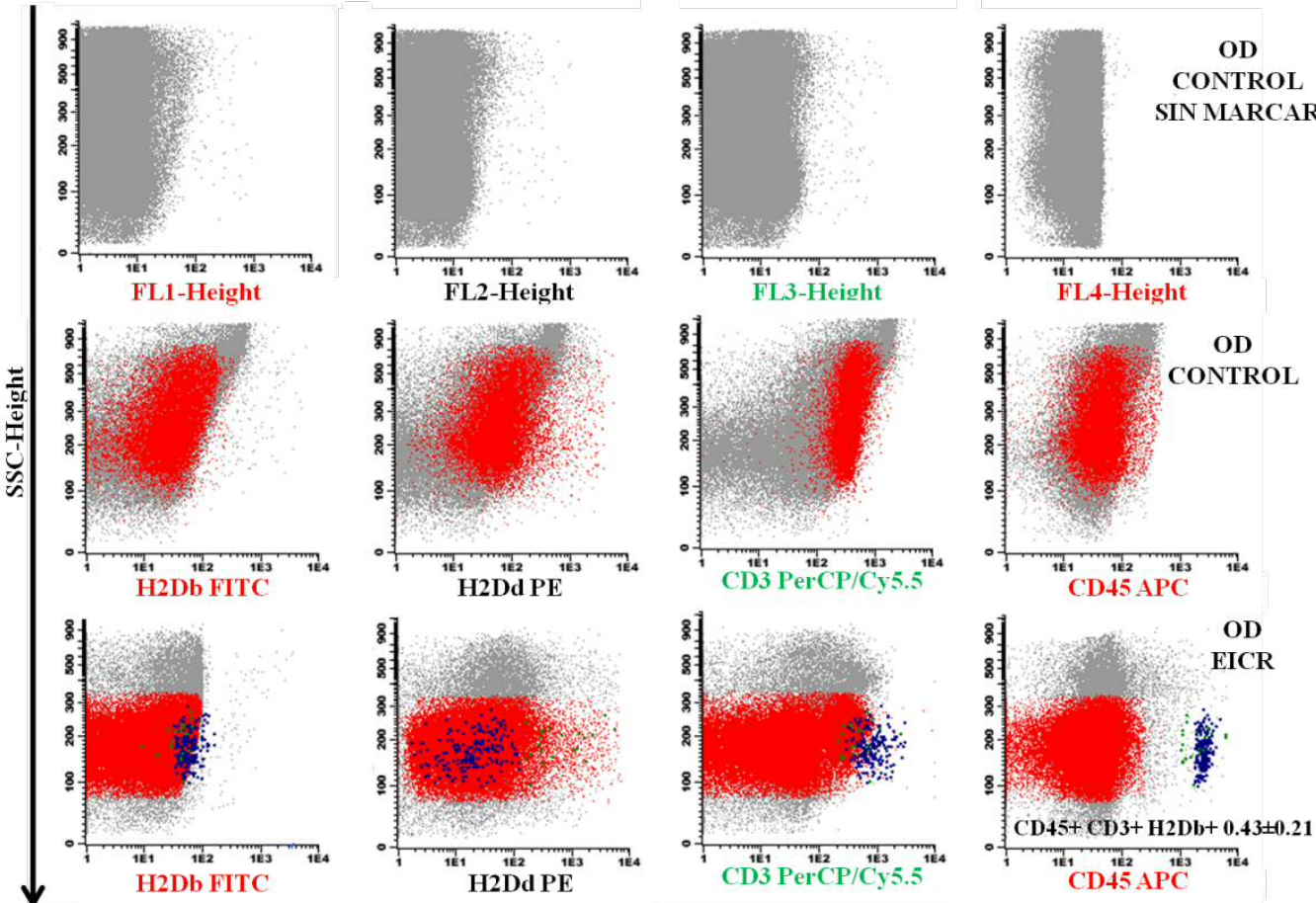

Fig. 44. Análisis de la infiltración linfocitaria mediante técnicas de citometría de flujo de la población $\mathrm{CD}^{+} / \mathrm{CD} 45^{+} / \mathrm{H} 2 \mathrm{D}^{\mathrm{b}+}$ en ojo derecho e izquierdo en ratones control y con EICR. El ojo derecho de los animales con EICRo se trató por vía subconjuntival con hCSM. 
En las Fig. 45 y 46 se pone de manifiesto la significativa disminución del porcentaje de infiltración linfoide glandular $\mathrm{CD}^{+} / \mathrm{CD} 45^{+} / \mathrm{H} 2 \mathrm{D}^{\mathrm{b}+}$ en el OD de los ratones $\mathrm{BALB} / \mathrm{c}$ con EICRo tratados por vía subconjuntival con $2 \times 10^{5}$ hCSM $(0.43 \pm 0.21)$ en comparación con el OI no tratado $(1.86 \pm 0.93)$.

\section{PORCENTAJE DE INFILTRACIÓN LINFOIDE GLANDULAR MEDIANTE CITOMETRÍA DE FLUJO}

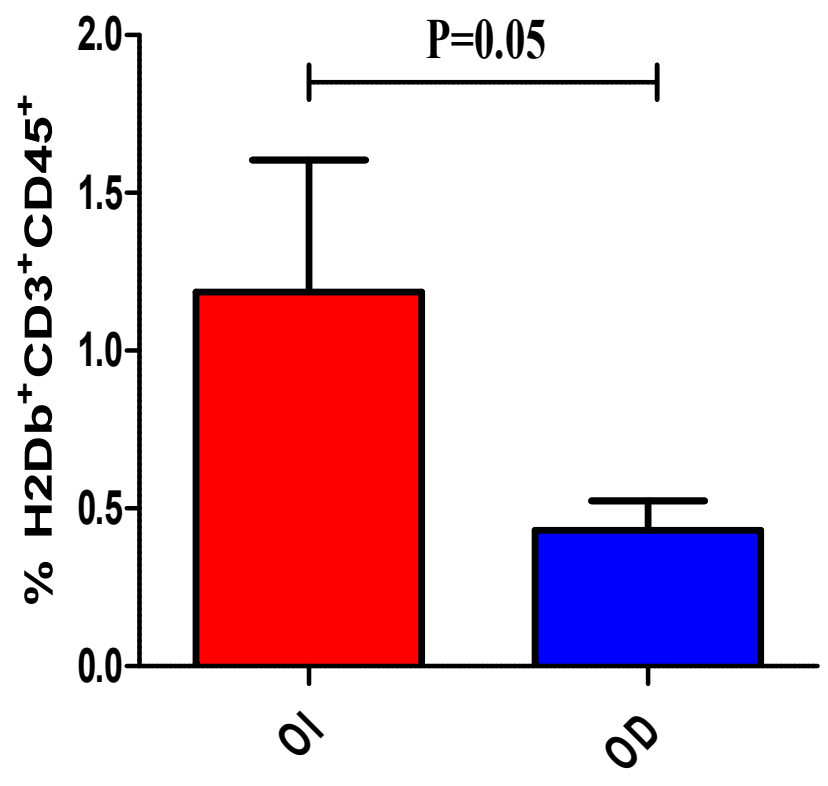

\begin{tabular}{|c|c|c|c|}
\hline & OI & 0D & P \\
\hline$\% \mathrm{H} 2 \mathrm{Db}+\mathrm{CD} 3+\mathrm{CD} 45+$ & $1.86 \pm 0.93$ & $0.43 \pm 0.21$ & 0.05 \\
\hline
\end{tabular}

Fig. 45. Cuantificación de la infiltración linfoide glandular procedente del donante C57BL/6 mediante citometría de flujo en OI no tratado y OD tratado de ratones BALB/c. El OD se trató con 2 X10 $10^{5}$ hCSM y se analizaron transcurridas 4 semanas de su administración subconjuntival. 


\section{INFILTRACION GLANDULAR EN OJOS TRATADOS CON CSM}

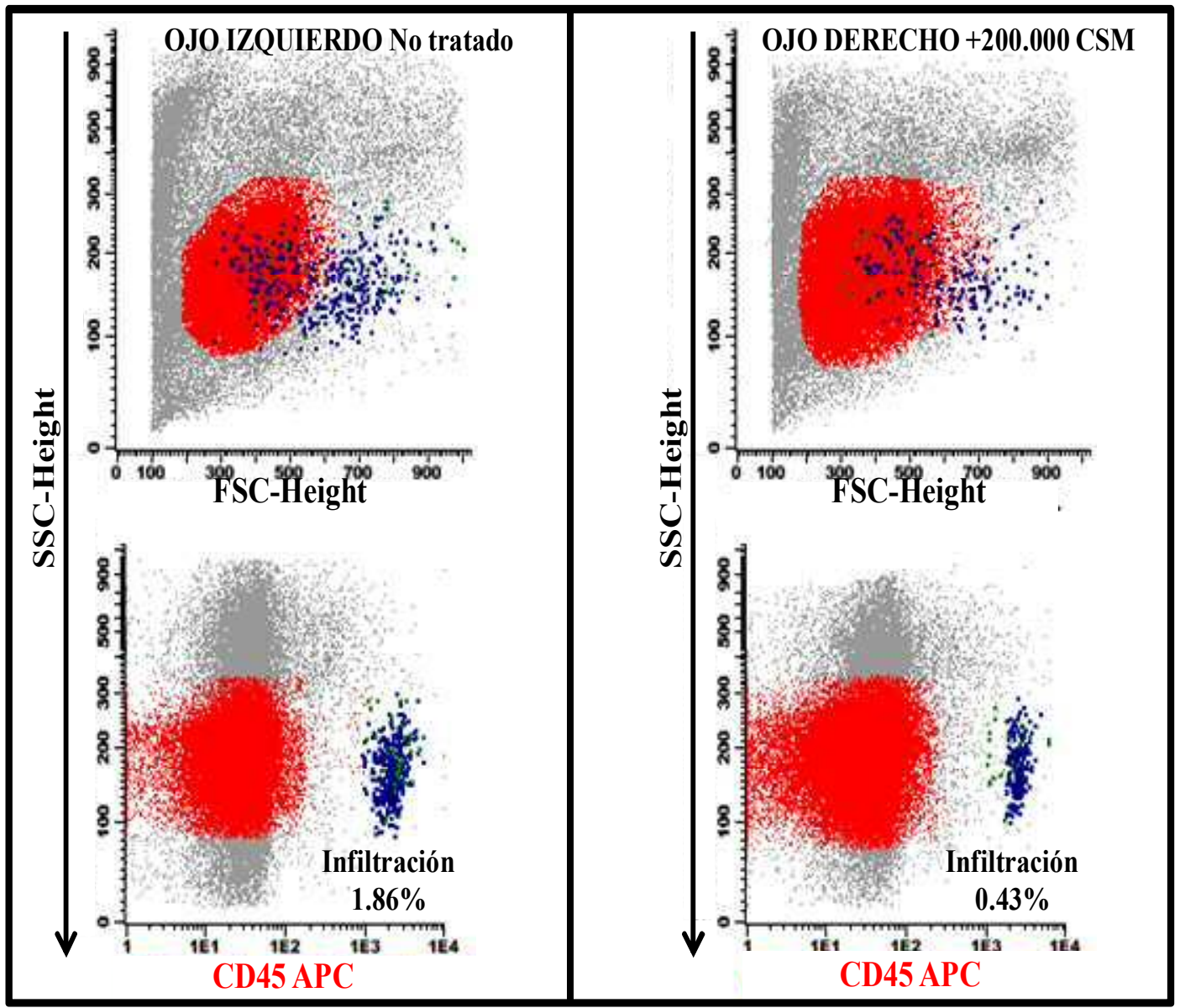

Fig. 46. Representación comparativa mediante citometría de flujo de la población linfoide infiltrada en la glándula lagrimal del OI no tratado y del OD tratado de ratones BALB/c con EICRo transcurridas 4 semanas de la administración subconjuntival de 2 X10 $10^{5}$ hCSM. 


\subsection{Diferenciación de las poblaciones que constituyen el}

\section{infiltrado linfoide de etiología inflamatoria en glándulas}

\section{lagrimales de ratones con EICRo}

Mediante técnicas de citometría de flujo se pudo caracterizar el infiltrado linfoide que presenta la glándula lagrimal de ratones a los que se ha trasplantado y generado EICRo empleando el modelo C57BL6 en BALB/c. En la Fig. 47 se pone de manifiesto que el epitelio acinar se localiza infiltrado mayoritariamente de linfocitos $\mathrm{CD}^{+}$.

\section{INFILTRACIÓN LINFOCITARIA DE LA GLÁNDULA LAGRIMAL}

EN RATONES CON EICR

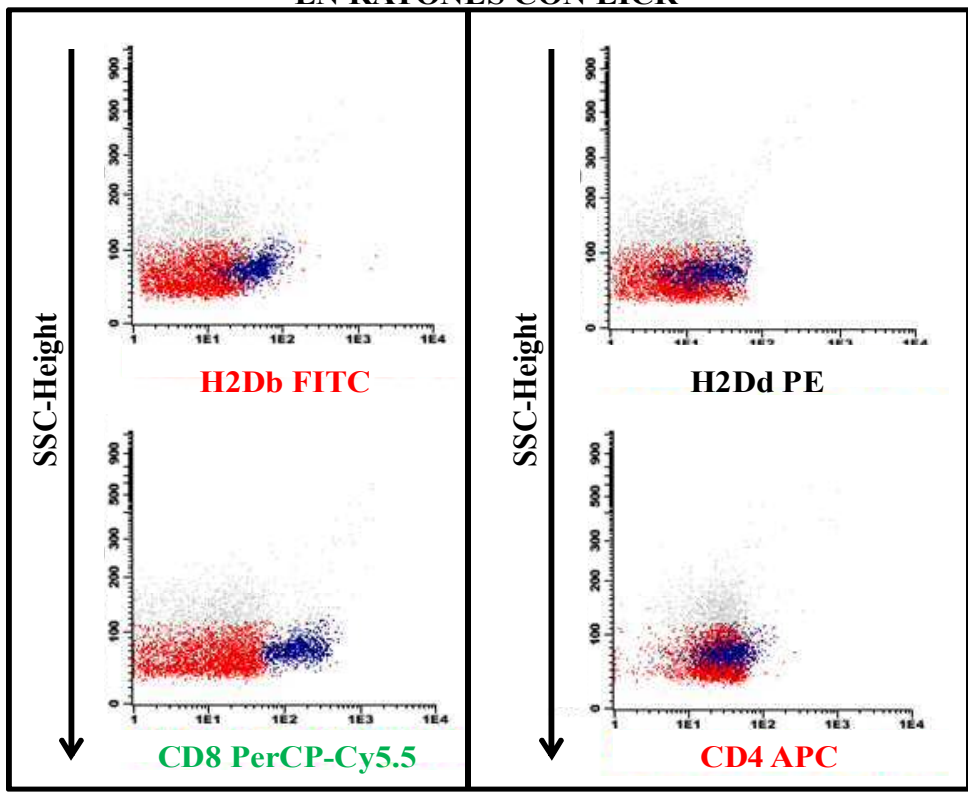

Fig. 47. Representación mediante citometría de flujo de la población linfoide $\mathrm{CD}^{+}$que infiltra la glándula lagrimal de ratones BALB/c 38 días después de la generación de EICRo empleando el modelo de trasplante y generación de EICR C57BL6 en BALB/c. 


\subsection{Efecto ejercido por las hCSM administradas por vía subconjuntival frente a la EICRo}

\subsubsection{Análisis clínico de la afectación ocular. Monitorización}

Las características macroscópicas del ojo derecho y del ojo izquierdo de los ratones $\mathrm{BALB} / \mathrm{c}$ a los que se generó EICRo, se valoraron independientemente, 2 veces por semana, teniendo en cuenta: el pelo periocular, el borde palpebral y el blefarospasmo. Se establecieron 3 grados de afectación clínica dependiendo de los signos macroscópicos observados en los ratones (valoración 0,1 y 2) tal y como se describió en el apartado 3.2.8.2 de Material y Métodos. En la Fig. 48, se establecen las diferencias oculares entre el grupo control (MO) y el de EICR diferenciando dentro de ambos el ojo derecho del izquierdo. En el caso del grupo de EICR, el ojo derecho es sobre el cual se inyectaron hCSM por vía subconjuntival mientras que el izquierdo no recibió tratamiento. La monitorización ocular reveló una mayor puntuación en el ojo izquierdo no tratado frente al derecho, lo que indica una mejoría clínica del ojo tratado mediante hCSM por vía subconjuntival en sujetos afectados por EICRo.

\section{Ojos}

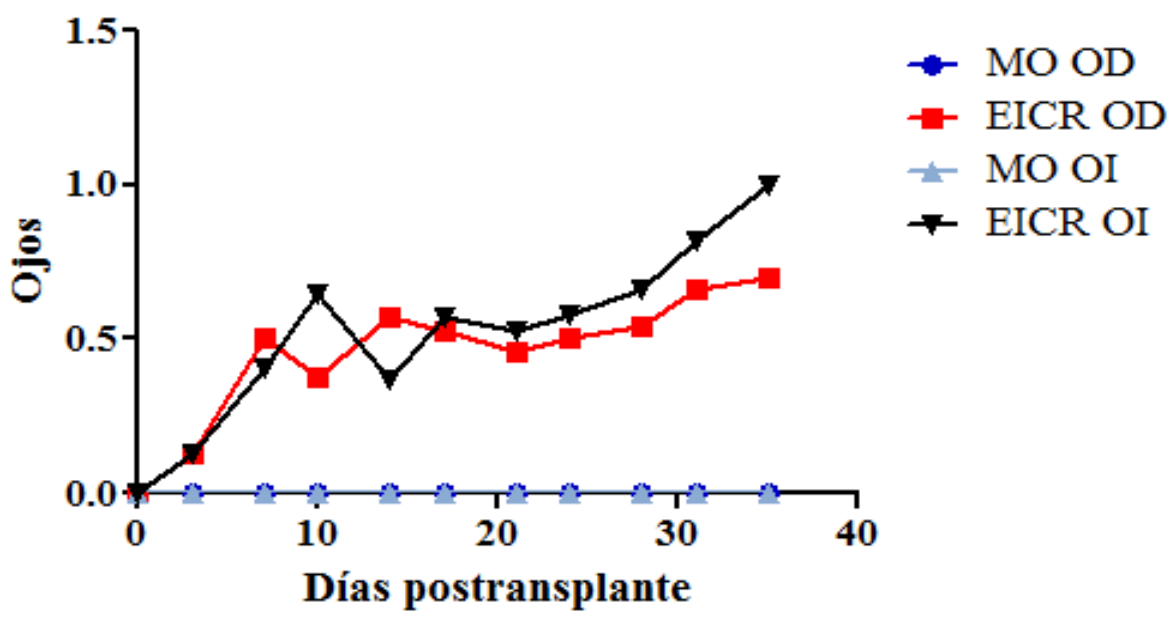

Fig. 48. Monitorización de la afectación ocular del OD y OI del grupo control y EICR. 


\subsubsection{Examen histológico mediante hematoxilina-eosina de la}

\section{glándula lagrimal tratada mediante inyección subconjuntival de hCSM}

Mediante la tinción hematoxilina-eosina se observaron los cambios anatomopatológicos entre los distintos grupos (controles, EICRo y EICRo+hCSM GFP+ administradas por vía subconjuntival) permitiendo establecer diferencias estructurales entre cada uno de ellos (Fig. 49).

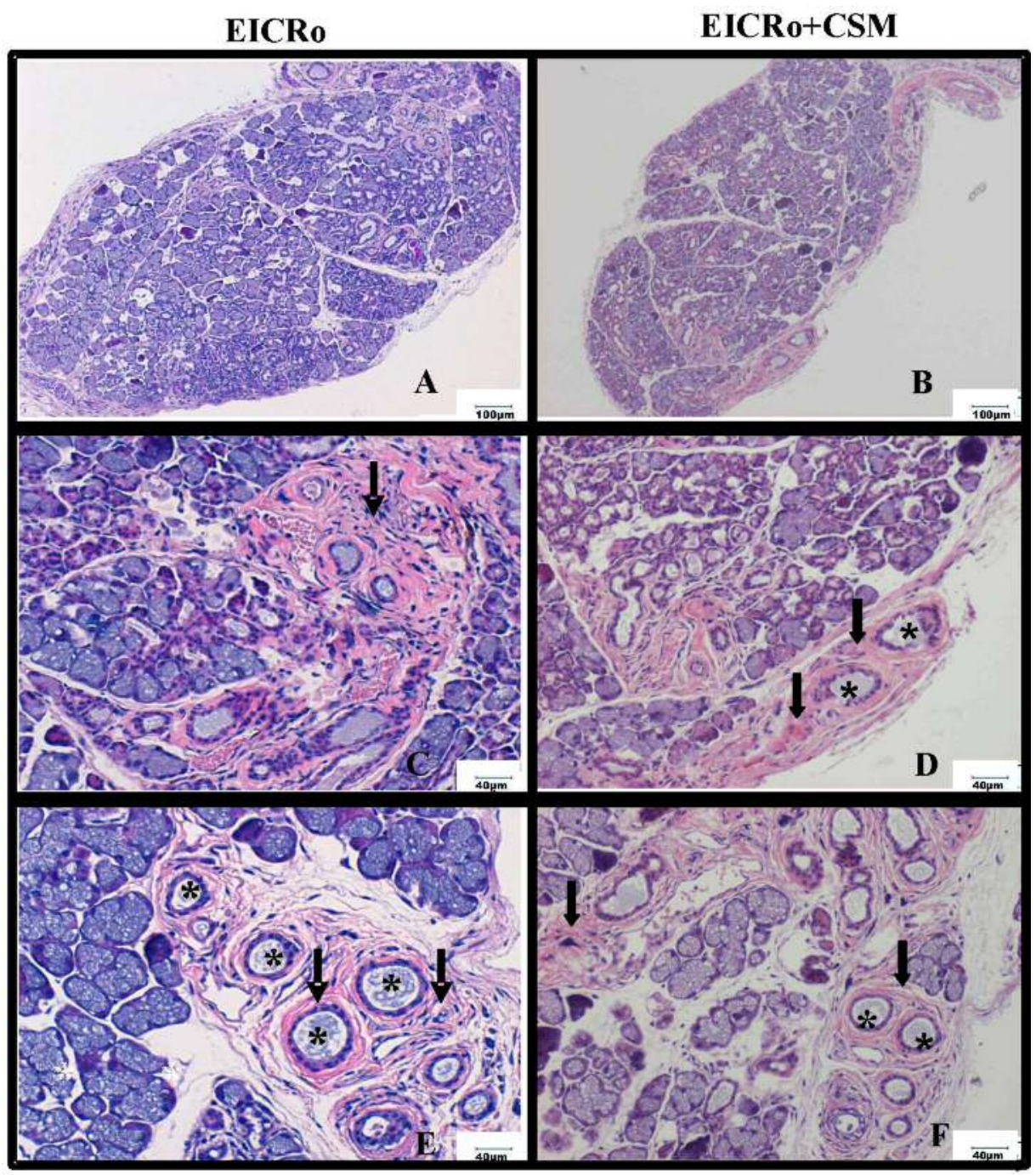

Fig. 49. A y B. Cambios histológicos en tejido en tejido glandular de ratón con EICRo y ratón tratado con hCSM por vía subconjuntival después de 4 semanas. Magnificación x 10 C y D. Importante fibrosis alrededor de los conductos excretores acompañados de infiltrado inflamatorio (flechas), más acentuada en el ratón con EICRo respecto a la muestra de ratón tratado, el cual muestra una leve disminución de la fibrosis periductal. Magnificación x20. E. Detalle con microscopia óptica de la dilatación intraductal (asteriscos) y del infiltrado inflamatorio difuso (flechas) en ratones con EICRo. Magnificación x 20. F. Discreta disminución de la fibrosis periductal e intersticial así como del infiltrado inflamatorio en la muestra de ratón tratado. La morfología canalicular se mantiene igual que en ambos casos (asteriscos).

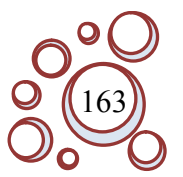




\subsubsection{Examen histológico mediante hematoxilina-eosina del}

\section{párpado tratado mediante inyección subconjuntival de hCSM}

A nivel de la conjuntiva tarsal, no se evidenciaron cambios anatomopatológicos entre ambos grupos. Mediante la tinción de hematoxilina-eosina objetivamos la presencia de metaplasia escamosa, alteración en el volumen de células caliciformes conjuntivales, presencia de cuerpos apoptóticos y vacuolización de los estratos basales del epitelio conjuntival en ambos grupos (Fig. 50).

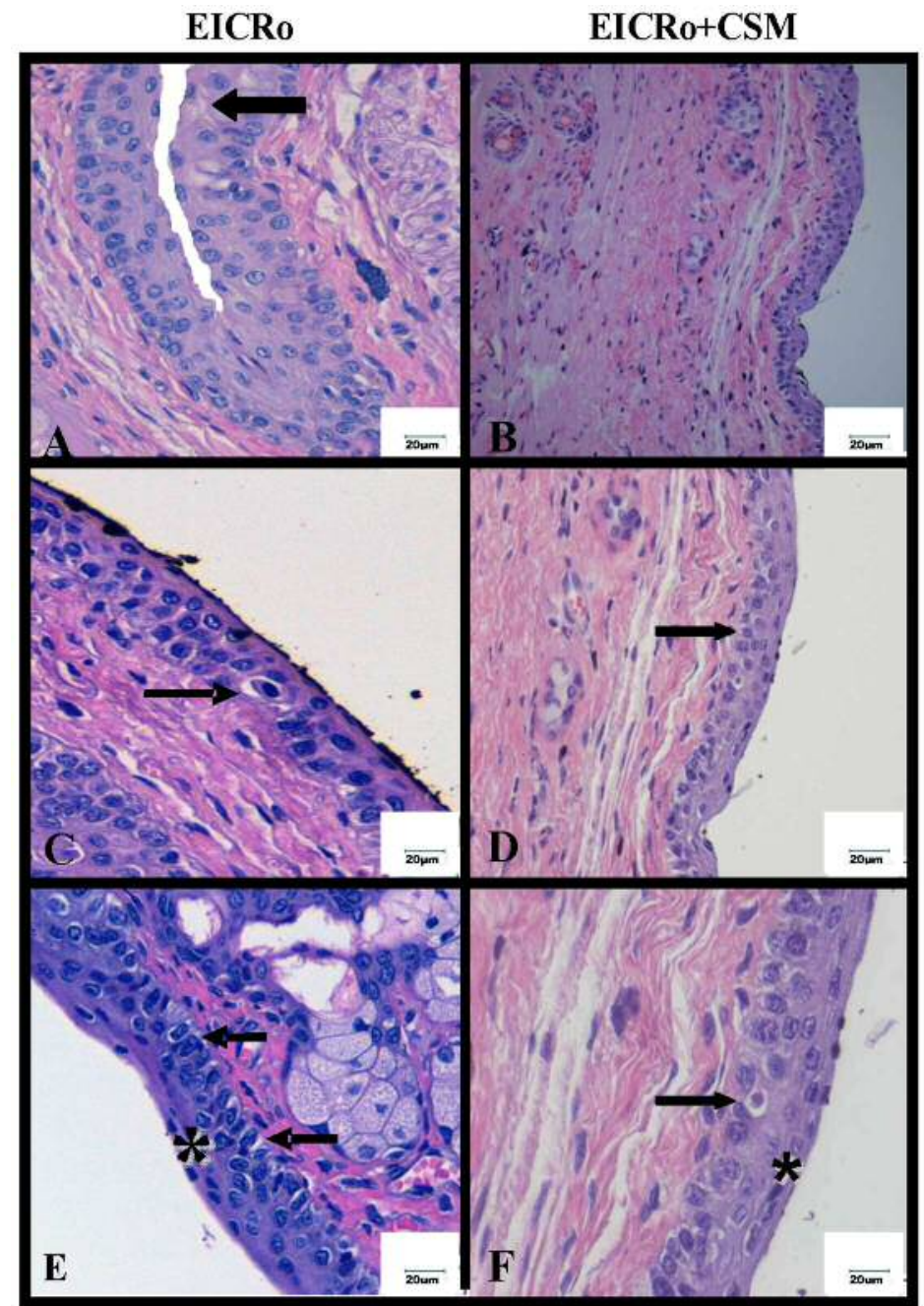

Fig. 50 A. Secreción mucosa aislada en conjuntiva de ratón con EICRo (flecha). Magnificación x40. C. Detalle de cuerpo apoptótico en conjuntiva tarsal de ratón con EICRo (flecha). Magnificación x40. E. Metaplasia escamosa en conjuntiva tarsal (asterisco). Se observan cuerpos apoptóticos y vacuolización de los estratos basales del epitelio conjuntival (flecha). Magnificación x40. Estos mismos fenómenos aparecen en las muestras de ratones tratados. B y D. Presencia de vacuolización de los estratos basales del epitelio conjuntival (flecha). F. Detalle de cuerpo apoptótico (flecha) y metaplasia escamosa (asterisco) 


\subsubsection{Análisis de las variaciones en la producción de lágrima}

El análisis de la lágrima mostró una reducción significativa del volumen en los ratones en los que se generó EICRo $(2,30 \mathrm{~mm} \pm 0,79)$ frente a los que solo fueron trasplantados con $\mathrm{MO}(2,88 \mathrm{~mm} \pm 0,78)$. Transcurridos 10 días del trasplante y generación de EICRo se administraron por vía subconjuntival de 2x10 hCSM GFP+. Después de 11 días de la inyección de las hCSM (21 días postrasplante) se recuperaron los valores de la producción de lágrima. EICR+hCSM (2.88 \pm 0.94$)$ (Fig. 51).

\section{MEDIDA DE LA PRODUCCIÓN DE LÁGRIMA PRUEBA DEL ROJO FENOL}

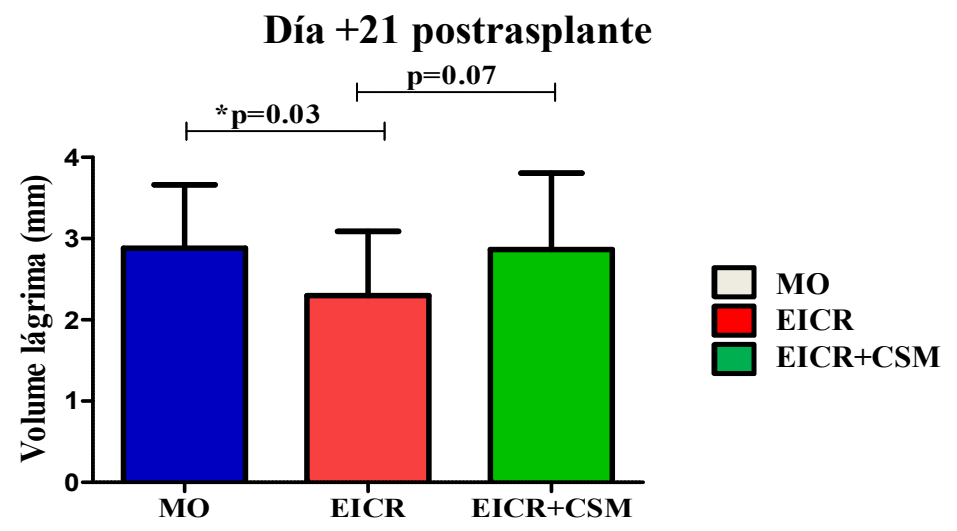

\begin{tabular}{|c|c|c|c|}
\hline & MO $(\mathrm{N}=22)$ & EICR $(\mathbf{N}=18)$ & EICR + CSM (N = 15) \\
\hline Volumen $(\mathrm{mm})$ & $2,88 \pm 0,78$ & $2,30 \pm 0,79$ & $2.86 \pm 0.94$ \\
\hline
\end{tabular}

Fig.51. Diferencias entre el volumen lagrimal de la población del grupo MO, EICR y EICR+CSM. 


\subsubsection{Análisis de las variaciones en la osmolaridad de la película}

\section{lagrimal}

En el grupo de ratones a los que se generó EICRo y en relación al grupo control, el análisis de la lágrima mediante el empleo de un osmolarímetro de TerLab mostró un aumento de la osmolaridad y de la salinidad de la lágrima (EICR $353 \mathrm{mOsm} / \mathrm{L} \pm 20$, MO $326 \mathrm{mOsm} / \mathrm{L} \pm 19$ ). Transcurridos 10 días del trasplante y generación de EICRo se administraron por vía subconjuntival de $2 \times 10^{5} \mathrm{hCSM} \mathrm{GFP}^{+}$. Después de 11 días de la inyección de las hCSM (21 días postrasplante) se recuperaron los valores de osmolaridad del grupo control EICR+hCSM (329 \pm 24$)$ (Fig. 52).

\section{OSMOLARIDAD DE LA PELÍCULA LAGRIMAL \\ Día +21 postrasplante}

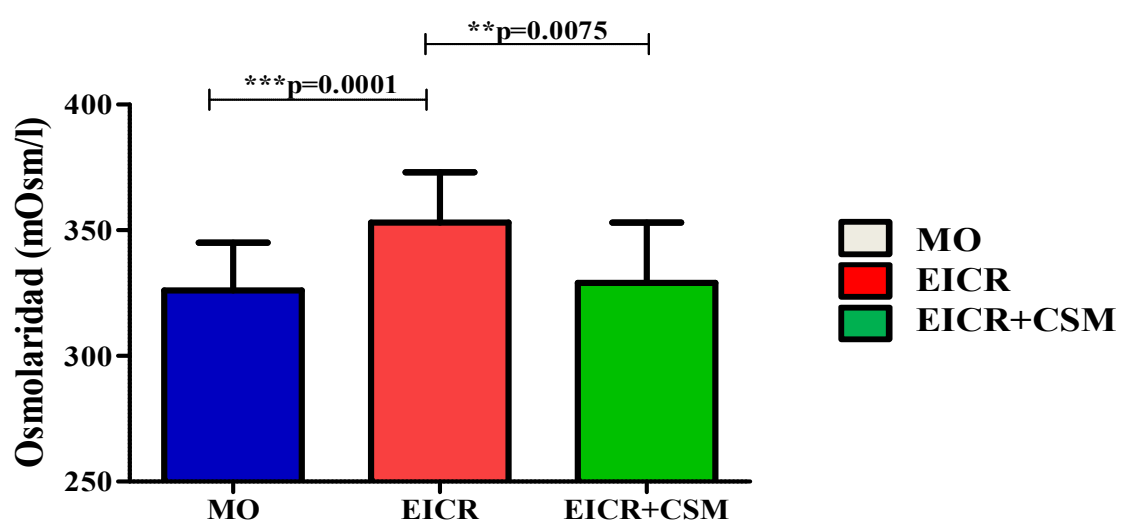

\begin{tabular}{|c|c|c|c|}
\hline & MO $(\mathrm{N}=22)$ & EICR $(\mathbf{N}=18)$ & EICR + CSM (N = 13) \\
\hline Osmolaridad (mOsm/l) & $326 \pm 19$ & $353 \pm 20$ & $329 \pm 24$ \\
\hline
\end{tabular}

Fig. 52. Diferencias entre la osmolaridad de la población del grupo MO, EICR y EICR+CSM. 


\subsubsection{Alteración en el tamaño y granularidad de la glándula}

\section{lagrimal}

Mediante citometría de flujo observamos que las células de la glándula lagrimal procedentes de ratones $\mathrm{BALB} / \mathrm{c}$ con EICR presentan diferencias morfológicas de tamaño y granularidad mediante citometría de flujo si se comparan con las del ratón control (Fig. 53). Estas diferencias en cuanto al tamaño y la complejidad interna de las células de la glándula lagrimal no son tan acusadas en los ojos tratados con hCSM por vía subconjuntival transcurridas 4 semanas de la infusión. Las células de glándula lagrimal control presentan una apariencia redondeada mientras que las células de las glándulas lagrimales procedentes de ratones receptores con EICRo aparecen elongadas y con un menor tamaño celular. Muchos de estos cambios morfológicos son consecuencia de la inflamación e infiltración linfocitaria derivada de la EICRo provocando entre otros muchos efectos la condensación de la cromatina nuclear y desintegración de la membrana plasmática en las células glandulares.

TAMAÑO y GRANULARIDAD DE LA GLÁNDULA LAGRIMAL

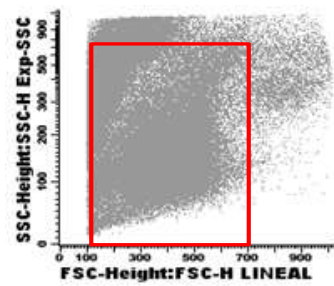

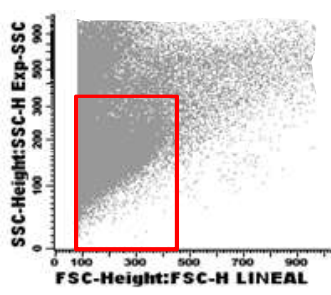

OI

RATÓN EICR

NO TRATADO

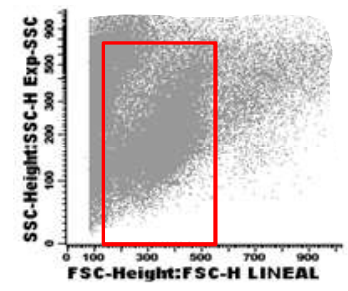

OD

RATÓN EICR

4 sem. Postinfusión de hCSM

Fig. 53. Alteración en el tamaño y la granularidad en ratones control (A), OI de ratones con EICR (B) y OD de ratón. 

5. Discusión

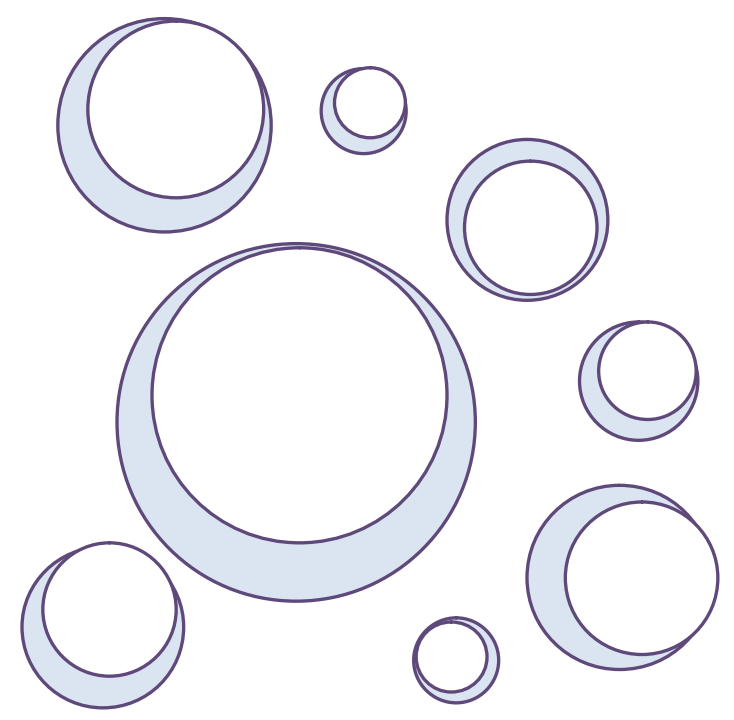





\section{DISCUSIÓN}

Plantearemos la discusión subdividiéndola en los tres apartados principales del trabajo:

- 5.1. Optimización del modelo murino de ojo seco secundario a EICR.

- 5.2. La administración subconjuntival de CSM.

\section{- 5.3. El efecto terapéutico de las CSM en la EICR.}

\subsection{Optimización del modelo murino de ojo seco secundario a EICR}

La EICR es una complicación inmunológica compleja debida al efecto citotóxico de los LT del donante frente a los tejidos y órganos del paciente. El síndrome de ojo seco secundario a la EICR constituye una complicación que afecta de forma grave a la superficie ocular y para la que actualmente no existe tratamiento etiológico. Las opciones terapéuticas se limitan a atenuar las manifestaciones clínicas asociadas al ojo seco dado que habitualmente no responden a los tratamientos estándar empleados.

La EICRo es una complicación grave e invalidante del trasplante hematopoyético que en muchos casos evoluciona hacia una alteración de la superficie ocular que llega a cronificarse, afectando a la calidad de vida de los pacientes así como a su función visual, causando en algunos casos la pérdida completa y permanente de visión ${ }^{56,61,91,224}$. Por este motivo, son necesarias nuevas estrategias terapéuticas que puedan aminorar esta sintomatología e incrementar la calidad de vida de los pacientes con EICRo. La comprensión de la fisiopatogenia de la enfermedad así como la inflamación derivada de la misma es un requisito previo para poder llevar a cabo una intervención terapéutica específica y eficaz. No se conoce con exactitud y está escasamente estudiada la físiopatología de la EICRo en general y la de la glándula lagrimal y de los parpados en particular. Por este motivo, uno de las primeros objetivos

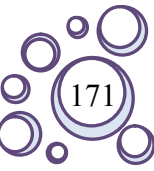


de nuestro grupo fue la generación de un modelo murino de EICRo. Lorenzo y cols., describieron en 2011 las características histopatológicas que involucran a la córnea y al limbo esclerocorneal y que constituyen parte esencial de la fisiopatología de la enfermedad a nivel corneal. Este modelo nos ha permitido evaluar nuevas estrategias terapéuticas para el tratamiento de la EICRo en un modelo preclínico ${ }^{224}$.

Las CSM, se han empleado en el tratamiento de la EICR y de citopenias postrasplante en diversos ensayos clínicos por sus propiedades reparadoras e inmunomoduladoras. En cultivo las hCSM constituyen una población heterogénea de células de morfología fusiforme con aspecto fibroblástico con propiedades tróficas, inmunomoduladoras y antiinflamatorias que pueden influenciar el destino y la actividad de las células normales, después de implantadas en zonas de tejido dañado o lesionado.

De hecho, nuestro grupo ha puesto de manifiesto recientemente que CSM generadas a partir de MO humana son capaces de migrar y de diferenciarse en células corneales después de ser administradas mediante inyección subconjuntival en el ojo derecho de ratones $\mathrm{BALB} / \mathrm{c}$ con EICRo. Las hCSM inyectadas contribuyen a la recuperación funcional e histológica de la superficie ocular de los animales tratados (Sánchez-Abarca y cols. ${ }^{225}$ ). En este estudio se describieron los cambios anatomopatológicos de la superficie ocular en el modelo murino de EICRo. Por este motivo, este trabajo se sustenta en el establecimiento, desarrollo y validación de un modelo murino de ojo seco que permita definir las alteraciones clínicas, histológicas y anatomopatológicas oculares de otras estructuras diana de la EICRo como pueden ser los párpados y la glándula lagrimal en el que se nos permita analizar la osmolaridad y el volumen de secreción de lágrima. Posiblemente, la investigación de estas alteraciones y la posibilidad de establecer nuevos tratamientos en glándula lagrimal y párpado no se han valorado previamente debido a la ausencia de un modelo animal establecido donde 
se pudiera demostrar la afectación de estas estructuras por la enfermedad. Por tanto, una de las originalidades del presente trabajo de tesis ha sido el desarrollo y validación de un modelo murino de EICRo con ojo seco, mediante el análisis de la afectación de la glándula lagrimal y de los párpados partiendo de un modelo de EICR murino estándar. Sin embargo, la evolución de la EICR sistémica murina es independiente de la EICRo tratada con diferentes estrategias terapéuticas basadas en el tratamiento local. Por ello se limita la mejoría en la evolución ocular a la supervivencia del ratón y no es posible observar si la mejoría perdura a largo plazo.

El síndrome de ojo seco es un trastorno autoinmune de la superficie ocular, que afecta hasta un $35 \%$ de la población adulta ${ }^{256,257}$. Se caracteriza por una inflamación de la superficie ocular pero también está implicada en gran medida la región palpebral ${ }^{258}$. Además, las anormalidades observadas en los párpados contribuyen clínicamente en la enfermedad de la superficie ocular, a menudo en forma de disfunción de las glándulas de Meibomio ${ }^{259}$, que también es una manifestación común de $\mathrm{EICR}^{56}$.

Desde el punto de vista macroscópico, la piel palpebral de los ratones BALB/c a los que se les generó EICR mostró en la mayoría de los casos distintos grados de alopecia y eritema periocular acompañado de irregularidad del borde libre palpebral, debido a un proceso de pérdida de sustancia secundario a úlceras y costras de distinta gravedad. En todos los casos, la primera manifestación de afectación ocular en los ratones fue el blefaroespasmo. Todos los síntomas observados a nivel palpebral son compatibles con los observados por Pérez y cols en sus nuevos criterios de evaluación de la EICRo murina ${ }^{258}$.

Desde el punto de vista anatomopatológico en la piel de los párpados de los ratones con EICRo, se observó una infiltración linfocítica de tipo inflamatorio en las distintas capas, dermis y epidermis. Además también frecuentemente se detectó la 
presencia de vacuolización, satelitosis y apoptosis en estos estratos cutáneos, todo ello hallazgos característicos de la EICR cutánea.

En cuanto a la afectación de la conjuntiva palpebral de los ratones que desarrollaron EICRo se pudo observar en la gran mayoría de los casos, procesos de queratosis y paraqueratosis con pérdida de células epiteliales, exocitosis de linfocitos y necrosis en satélite con evidencia de cuerpos apoptóticos en el epitelio conjuntival a nivel anatomopatológico. Esta apoptosis, se hizo patente mediante la tinción con el anticuerpo Caspasa 3. Así mismo, en las muestras conjuntivales examinadas, tal y como se ha descrito a nivel cutáneo, apareció un infiltrado linfocitario difuso inflamatorio. Todas estas alteraciones son compatibles con la EICR descrita por National Institutes of Health consensus development project on criteria for clinical trials in chronic graftversus-host disease.

A pesar de que apenas existe bibliografía que describa las características macroscópicas y microscópicas de la conjuntiva en pacientes o modelos animales de EICR, en el modelo murino de ojo seco que hemos desarrollado pudimos constatar un aumento de células inflamatorias en la conjuntiva tarsal. En pacientes sometidos a un trasplante alogénico Rojas y cols. pusieron de manifiesto que en la conjuntiva se pueden detectar a nivel epitelial células CD3+ y CD14+. En el estroma, hay una mayor proporción de LT (CD3+, CD4+, CD8+) y células CD14+ con expresión de VLA-4 y LFA-1. En los pacientes trasplantados que mostraron síntomas de ojo seco, se incrementó el porcentaje de células CD14+ en epitelio y estroma ${ }^{54}$, desvinculando por completo a las células NK de este proceso. Por tanto, la presencia de células CD3 y CD14 y el aumento de citocinas proinflamatorias ${ }^{55}$ serían responsables del proceso de queratinización típico que aparece en la conjuntiva tarsal de pacientes con EICRo tras un trasplante alogénico. 
Aronni y cols. ${ }^{54}$ también demostraron en su trabajo que en pacientes con EICRo existe una importante disminución de la densidad de células caliciformes que está directamente correlacionada con una disminución en el resultado del test de Schirmer.

En nuestro trabajo, mediante la técnica PAS-Azul Alcian, observamos que la secreción mucosa por parte de las células caliciformes en los ratones con EICRo se encuentra deplecionada siendo prácticamente nula en alguna de las muestras procesadas transcurridos 38 días del trasplante y generación de EICRo. La disminución en la densidad de células caliciformes se confirmó mediante técnicas de citología de impresión conjuntival. Las células epiteliales que aparecen en nuestras muestras de conjuntiva murina de ratones con EICRo son poligonales y de gran tamaño con límites poco definidos y con una mayor separación, dejando grandes espacios intercelulares entre ellas y su porcentaje está claramente reducido. En ninguna de nuestras muestras hemos objetivado procesos de fibrosis conjuntival.

En cuanto a la afectación de la glándula lagrimal, la glándula de los ratones a los que previamente se había generado una EICRo se objetivó histológicamente de forma constante bajo microscopia óptica la presencia de una dilatación de los conductos secretores, estasis de su contenido y fibrosis periductal acompañada de infiltración linfocitaria localizada. Estos hallazgos coinciden con los descritos en los trabajos de Ogawa y cols. ${ }^{260}$ donde detallan la afectación de la glándula lagrimal humana. Además de todos los procesos descritos anteriormente, decriben que el infiltrado inflamatorio crónico de las zonas periductales se localiza principalmente alrededor de los conductos de tamaño medio y que también existe, aunque en menor medida en los acinos. Este infiltrado, según Ogawa y cols. ${ }^{260}$, está compuesto principalmente por LT CD4+ y CD8+. Al igual que en los estudios humanos, también encontraron macrófagos CD68+, 
mientras que la presencia de LB CD20+ fue insignificante. Estos LT activados ejercen múltiples funciones:

- Un efecto citotóxico sobre las células del parénquima induciendo su apoptosis.

- Un efecto estimulante sobre los fibroblastos incrementando su proliferación y la producción de matriz extracelular conduciendo a una fibrosis progresiva del tejido implicado ${ }^{261}$. Esta aseveración se demostró mediante un modelo murino por Yaguchi y cols ${ }^{262}$.

Hassan y cols. también trabajaron sobre un modelo murino de EICR y observaron cambios en la glándula lagrimal similares descritos por Ogawa y Yaguchi y todos ellos fueron coincidentes con nuestros resultados.

El análisis de la glándula lagrimal de nuestro modelo murino de EICR (C57BL/6 en $\mathrm{BALB} / \mathrm{c}$ ) mostró un infiltrado inflamatorio y linfocitario $\mathrm{T}$ de origen alogénico. Hemos podido determinar mediante citometría de flujo que el epitelio acinar está infiltrado mayoritariamente por linfocitos $\mathrm{CD}^{+}$. Estas células $\mathrm{T}$ desempeñan un papel muy importante en la activación y posterior regulación de la respuesta inmune. El infiltrado inflamatorio se asocia con una disminución del volumen en la producción de lágrima y un consiguiente aumento de la osmolaridad que reproduce la xeroftalmia ocular típica derivada de ojo seco por EICR humano. La película lagrimal posee diversas funciones, entre ellas, actúa como agente lubricante de la superficie ocular y también juega un papel fundamental en la defensa frente a la invasión de cuerpos extrínsecos. Una disminución de la cantidad o calidad de la lagrima puede provocar la aparición de defectos epiteliales, y conducir a queratitis recurrentes molestas, infecciones corneales e incluso, en los casos más extremos a perforaciones corneales $^{21,263}$. 
Clínicamente, se ha observado que la gravedad del ojo seco se correlaciona con el grado de cambios fibróticos, lo cual indica que la acumulación excesiva de matriz extracelular típica de este proceso contribuye a la disfunción exocrina de la glándula. Sin embargo, también se ha objetivado que la acción inflamatoria crónica debido a la existencia de esta infiltración linfocitaria permanente conduce a una atrofia glandular, lo cual se traduce también en una hipofunción de la glándula ${ }^{61}$. En este sentido, a día +21 postrasplante pudimos verificar que los ratones $\mathrm{BALB} / \mathrm{c}$ que recibieron $\mathrm{MO}$ y esplenocitos procedentes de ratones donantes C57BL6 y que desarrollaron EICRo presentaron un aumento de la osmolaridad ocular y una significativa reducción del volumen de lágrima en comparación con los ratones BALB/c que solo fueron trasplantados con MO.

Por todo lo descrito, en nuestro modelo de murino de EICR encontramos criterios suficientes para el diagnóstico de EICRo y todo ello se justifica mediante la correlación que existe entre este fenómeno y los hallazgos histológicos de la glándula lagrimal de pacientes no afectados por EICR los cuales muestran una arquitectura homogénea en su composición. Esta, se encuentra rodeada por un tejido conectivo laxo y adiposo, siendo excepcional el hallazgo de fibrosis y de infiltración celular de etiología inflamatoria.

\subsection{Administración subconjuntival de las hCSM}

La administración de hCSM mediante una inyección subconjuntival constituye una vía de administración celular segura, sencilla, y poco invasiva que evita el epitelio conjuntival no generando complicaciones clínicas posteriores. Existe un gran interés en la búsqueda y consolidación de nuevas vías de administración que consigan un 
incremento de las concentraciones intraoculares y que prolonguen el tiempo de actuación con respecto a la vía de administración tópica.

Numerosos fármacos antiinflamatorios, inmunomoduladores como tacrólimus o ciclosporina, suero autólogo con distintos factores de crecimiento, entre otros, se administran por vía tópica oftálmica para el tratamiento del ojo seco. Esta vía facilita la absorción de estos tratamientos aunque la duración de su efecto es limitada. La administración subconjuntival de hCSM requiere para su aplicación clínica de una sedación ocular local para llevar a cabo la inyección de las hCSM resuspendidas en un pequeño volumen de suero fisiológico, lo que sin duda puede limitar su generalización. Inicialmente, y con el fin de simplificar el procedimiento y facilitar su posterior traslación a la clínica testamos en nuestro el modelo murino de EICRo la administración tópica de las hCSM. Sin embargo, no obtuvimos los mismos resultados tanto a nivel palpebral como lagrimal.

La movilización de las hCSM se lleva a cabo debido a diferentes vías de señalización inducidas por necrosis, inflamación y otros procesos. El microambiente local así como la quimiotaxis inducida influyen en la capacidad de migración y diferenciación de las hCSM ${ }^{158,224}$.

Como se ha comentado anteriormente, la relación entre las CSM injertadas a largo plazo en los tejidos dañados y sus efectos terapéuticos no los hemos podido establecer definitivamente debido a que la supervivencia del ratón con EICR es limitada. De hecho, el posible efecto terapéutico de las hCSM administradas por vía subconjuntival es inverso al deterioro sistémico del animal. No obstante, hemos conseguido monitorizar la presencia de hCSM transducidas mediante técnicas de bioluminiscencia durante al menos 5 semanas tras su administración subconjuntival en el OD del ratón con EICRo produciendo una significativa disminución del porcentaje de 
infiltración linfoide glandular en el ojo tratado en comparación con el OI no tratado. Durante ese periodo de tiempo, nos resulta muy complicado discernir si el efecto beneficioso de las hCSM se debe a su capacidad de integración en el tejido murino dañado o bien a un efecto paracrino después de su migración al tejido afectado por la EICRo independientemente de su persistencia en el tejido (Fig. 54). La capacidad reparadora de CSM depende directamente del grado de inflamación del microambiente. Dado que las CSM están ampliamente distribuidas en casi todos los tejidos y tienen una clara actividad inmunosupresora en un contexto inflamatorio, parece lógico cuestionarse ¿por qué las CSM de los tejidos residentes endógenos no contribuyen a remediar los trastornos inmunológicos e inflamatorios en la misma medida que las CSM administradas exógenamente?

- Una posibilidad es que las propiedades inmunomoduladoras de las CSM se adquieran durante el cultivo in vitro.

- Otra posibilidad es que sea un efecto dependiente de la cantidad de CSM presentes (dosis celular). Concretamente, administramos $2 \times 10^{5} \mathrm{CSM}$ resuspendidas en $20 \mu 1$ de suero fisiológico por vía subconjuntival en el ojo derecho del ratón con EICRo. Esta concentración celular puede ser considerada como una alta dosis, teniendo en cuenta la propensión de las CSM a acumularse en las zonas de tejido dañado.

En cualquier caso, la falta de marcadores específicos que permitan analizar las CSM in vivo ralentiza el esclarecimiento de cómo las CSM responden a las diferentes condiciones inflamatorias. Sin embargo, llegar a comprender la capacidad inmunomoduladora de las CSM, tanto endógenas como exógenas, puede ser de gran ayuda para poder mejorar el uso terapéutico de las CSM. También, resultaría de gran interés desentrañar el distinto papel que juegan las hCSM en las diferentes etapas de la enfermedad. 


\section{MODELO DE REGENERACIÓN TISULAR MEDIADA POR CSM}

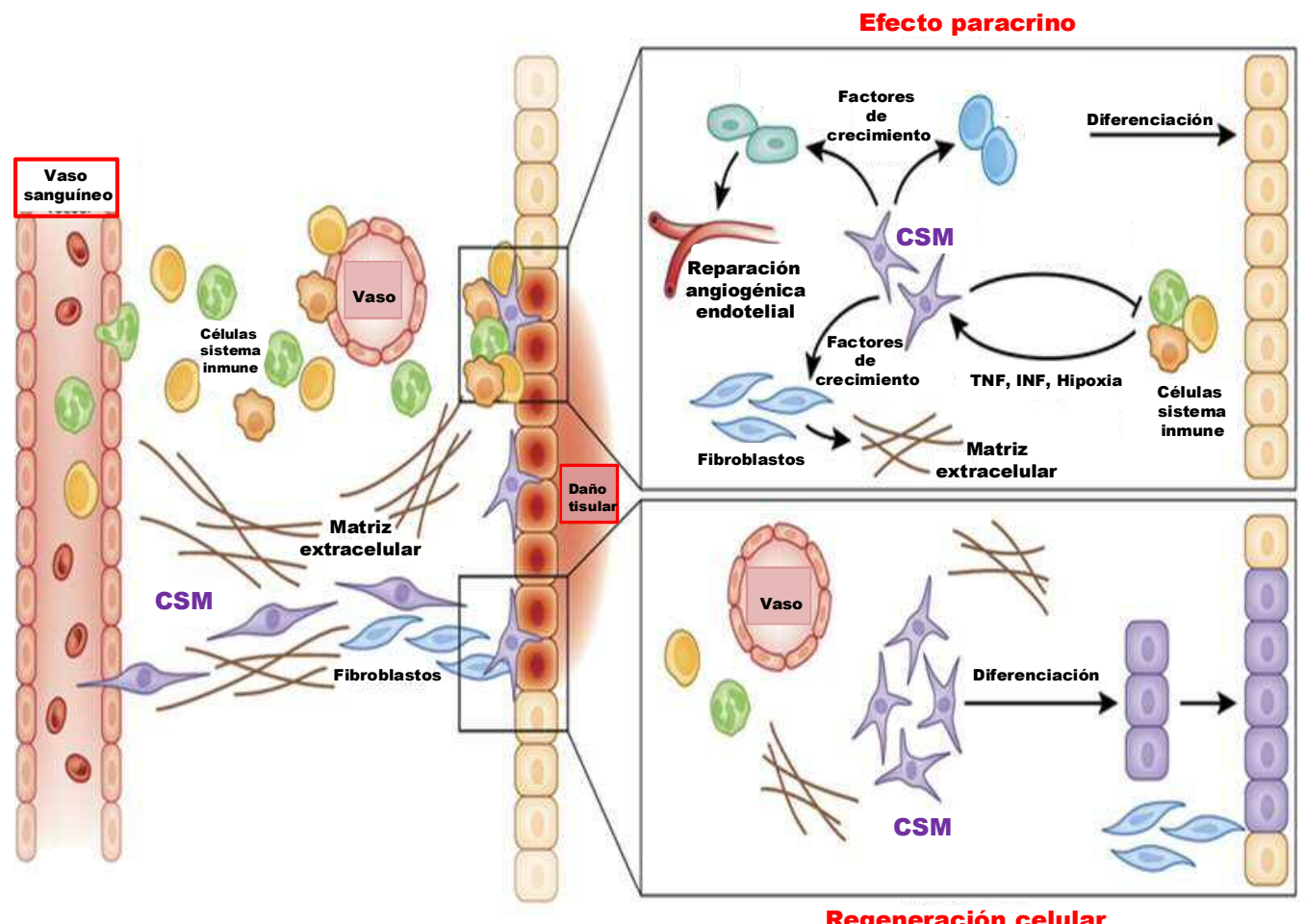

Regeneración celular

Fig. 54. Modelo de regeneración tisular mediada por CSM. Adaptado de Wang $Y$ et al. Nature Immunology. 15(11): 1009-1016. 2014.

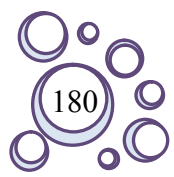




\subsection{Efecto terapéutico de la administración subconjuntival de hCSM}

\section{en un modelo de EICRo}

Con el fin de facilitar la evaluación de nuevas estrategias terapéuticas que puedan aminorar la sintomatología e incrementar la calidad de vida de los pacientes con EICRo en el presente trabajo de tesis doctoral nos propusimos desarrollar y validar un modelo murino de ojo seco que presente afectación a nivel palpebral y glandular y que permita evaluar de forma multiparamétrica los cambios macroscópicos, histológicos y funcionales de la EICRo generada. Comprender la inmunopatogenia de la enfermedad así como la inflamación derivada de la misma es un requisito previo para poder llevar a cabo una intervención terapéutica específica y eficaz. La administración de hCSM por via subconjuntival en el tratamiento de la EICRo puede favorecer la persistencia a largo plazo y prolongar su acción regeneradora, antiinflamatoria y regenerativa en la superficie ocular. Esta estrategia puede convertirse en una alternativa para el tratamiento de la EICRo dado que se favorece su capacidad de migración hacia la glándula lagrimal. Las hCSM inyectadas por vía subconjuntival contribuyen a la recuperación funcional e histológica de la superficie ocular de los animales con EICRo tratados ${ }^{225}$.

Las alteraciones clínicas, histológicas y anatomopatológicas oculares de los párpados y la glándula lagrimal y la investigación de la osmolaridad y el volumen de secreción de lágrima en ratones a los que se ha generado EICRo puede contribuir a establecer nuevos tratamientos que no se han valorado previamente debido a la ausencia de un modelo animal establecido donde se pudiera demostrar la afectación de estas estructuras por la enfermedad. Esta aproximación, sin embargo, no constituye un modelo perfecto debido a que la EICRo tratada con diferentes estrategias terapéuticas evoluciona de modo secundario a la EICR sistémica generada y la mejoría ocular está limitada por la supervivencia del ratón y no es posible constatar si esta mejoría perdura

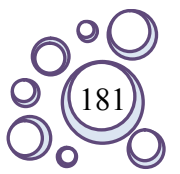


a largo plazo dado que el posible efecto terapéutico de las hCSM administradas por vía subconjuntival es inverso al deterioro sistémico del animal. Por este motivo, todas las medidas de osmolaridad y volumen de lágrima se hicieron a día +21 postrasplante. Es decir, las hCSM se administraron por vía subconjuntival trascurridos 10 días del trasplante y generación de la EICRo.

A día +21 postrasplante en los ratones a los que se había generado EICRo y no fueron tratados con hCSM se observó un aumento de la osmolaridad y una significativa disminución del volumen de lágrima. Sin embargo, en los ratones a los que se inyectó por vía subconjuntival $2 \times 10^{5}$ hCSM el día 10 postrasplante, se observó desde un punto de vista anatomopatológico, una discreta disminución de la fibrosis y del infiltrado inflamatorio periductal en la glándula lagrimal a la vez que se recuperaron los valores control tanto de osmolaridad como de volumen de lágrima. La evolución de la EICR sistémica animal nos impidió verificar ninguna mejoría en los valores de ambas variables a partir del día +21 postrasplante aunque si pudimos comprobar la presencia de células humanas tanto en la glándula como en el párpado mediante técnicas de inmunohistoquímica y bioluminiscencia hasta 5 semanas después de su administración.

\subsubsection{CSM y regeneración}

El registro de ensayos clínicos del Instituto Nacional de Salud de Estados Unidos (http://www.clinicaltrials.gov) revela que están activos un gran número de ensayos basados en la administración de CSM en todo el mundo. Muchos estudios han demostrado que el tratamiento con CSM mejora la condición clínica de los pacientes que sufren enfermedades cardiovasculares ${ }^{264}$, enfermedades hepáticas ${ }^{265}, \operatorname{EICR}^{228} \mathrm{y}$ otras enfermedades inmunes ${ }^{266,267}$. Muchos estudios preclínicos y clínicos han proporcionado evidencia de la eficacia de los tratamientos basados en la administración de CSM. En la mayoría de los casos, sin embargo, el porcentaje de hCSM que injertan 
en el tejido u órgano diana es escaso y su persistencia es transitoria, lo que indica que debe haber otros mecanismos por los que las hCSM ejercen su efecto terapéutico ${ }^{268,269}$.

Mediante inmunohistoquímica fuimos capaces de verificar la presencia de hCSM en glándula lagrimal y párpado empleando el doble marcaje GFP+ y mitocondria humana + transcurridos 10 y 30 días de su administración subconjuntival. Por tanto, la administración subconjuntival de hCSM posibilita su presencia a largo plazo en la superficie ocular y favorece su migración a la glándula lagrimal y al párpado.

Si la vía de administración de las hCSM transducidas es intravenosa se detectan fundamentalmente a nivel pulmonar $y$ esta señal se hace indetectable por bioluminiscencia transcurridas 2 semanas $^{228}$.

Empleando técnicas de citometría de flujo comprobamos una disminución del porcentaje de infiltración linfoide glandular por linfocitos $\mathrm{T}$ alogénicos $\mathrm{CD} 3+/ \mathrm{CD} 45+/ \mathrm{H}_{2} \mathrm{D}^{\mathrm{b}}+$ en el ojo derecho de los ratones BALB/c con EICRo tratados con la inyección subconjuntival de hMSC $(0.43 \pm 0.21)$ en comparación con el ojo izquierdo no tratado (1.86 \pm 0.93$)$ transcurridas 4 semanas de su administración. La persistencia en el tejido es clave para que las hCSM puedan contribuir a la reparación del mismo. Además, las hCSM en respuesta a mediadores inflamatorios, las hCSM pueden producir grandes cantidades de factores inmunorreguladores, factores de movilización celular y factores de crecimiento que facilitan así la reparación de tejidos dañados por células stem residentes del propio órgano o tejido ${ }^{272}$.

\subsubsection{Inflamación y CSM}

Cuando se produce un daño tisular, se genera inflamación que provoca la movilización de las CSM. En respuesta a las citocinas inflamatorias generadas, las CSM colaboran en la generación de un microambiente adecuado mediante la producción de factores inmunorreguladores que modulan la progresión de la inflamación. Las CSM

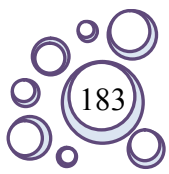


también producen grandes cantidades de factores de crecimiento, que posteriormente estimulan las células endoteliales, fibroblastos y, lo más importante, las células progenitoras de tejido in situ. La acción concertada de todos estos factores y la presencia de las CSM células facilita la reparación de tejidos a través de la angiogénesis, la remodelación de la matriz extracelular y la diferenciación de las células progenitoras de tejido ${ }^{273}$.

Entre los factores liberados por las CSM se incluyen la interleucina-6 (IL-6), TGF- $\beta$, la prostaglandina E2, HGF, el factor de crecimiento epidérmico (EGF), factor de crecimiento de fibroblastos (FGF), factor de crecimiento derivado de plaquetas (PDGF), factor de crecimiento endotelial vascular (VEGF), factor de crecimiento insulínico (IGF), factor derivado de células del estroma 1 (SDF-1), la enzima triptófanocatabólico (IDO) y el óxido nítrico (NO) ${ }^{274-277}$. En conjunto, estos factores secretados pueden inhibir las respuestas inflamatorias, la promoción de actividades endoteliales y fibroblastos, y facilitar la proliferación y diferenciación de células progenitoras en los tejidos de la zona afectada.

Las propiedades inmunomoduladoras confieren a las CSM un gran potencial para el tratamiento de los distintos procesos inflamatorios. No obstante los mecanismos exactos a través de los cuales las CSM median la inmunomodulación no están del todo determinados. Además, dependiendo del tipo y de la intensidad del estímulo inflamatorio se confiere a la CSM la capacidad de suprimir la respuesta inmune en algunos casos, o de mejorarla en otros ${ }^{277}$.

Parece evidente además que para ejercer su acción inmunomoduladora, las CSM precisan activarse por una combinación de citocinas inflamatorias, como el interferón- $\gamma$ (IFN- $\gamma$ ) en presencia de uno (o más) citoquina (s), incluyendo TNF, IL-1 $\alpha$ o IL-1 $\beta^{179}$. 
La capacidad inmunomoduladora de las CSM depende de los mediadores inflamatorios presentes en su microambiente y de sus concentraciones. De hecho, diferentes estados de inflamación pueden dar lugar a diferentes respuestas al tratamiento con CSM. Cuando la EICR se trata con CSM, el efecto beneficioso tiene lugar una vez que el proceso inflamatorio está ya en marcha, mientras que el tratamiento celular es mucho menos efectivo cuando las CSM se infunden junto a los progenitores hematopoyéticos antes de que la inflamación comience ${ }^{278,279}$. Por este motivo, la inyección subconjuntival de hCSM en nuestro modelo se realizó una vez que que aparecen los primeros síntomas EICR sistémico y ocular, lo que ocurre aproximadamente 10 días tras el trasplante murino de MO y generación de EICR. Del mismo modo, los efectos terapéuticos de las CSM en la encefalomielitis autoinmune experimental disminuyen cuando se administran las células durante remisión de la enfermedad ${ }^{280-282}$.

\section{INMUNOMODULACIÓN MEDIADA POR CSM}

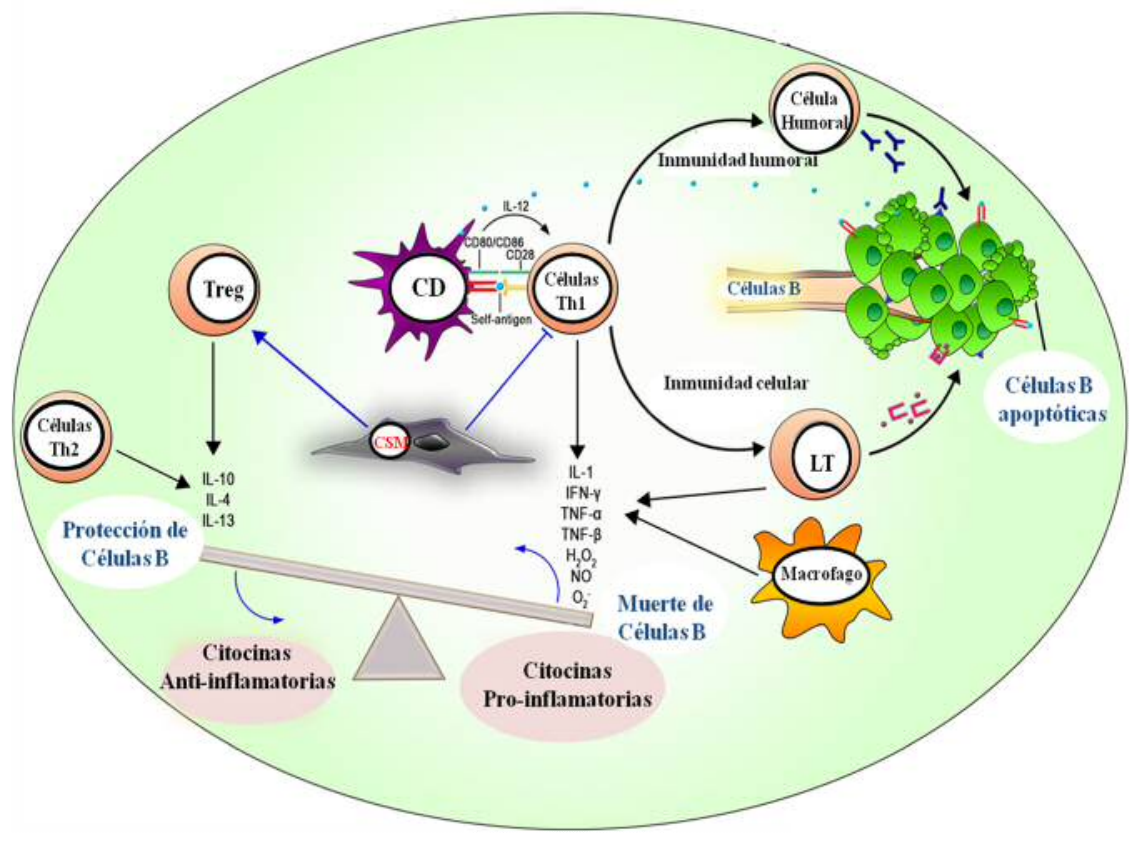

Fig. 55. Potencial inmunomodulador de las CSM. Adaptado de D'souza y cols. BMC Medicine .13:186. 2015. 
Por lo tanto, la condición inflamatoria es clave para la obtención del efecto inmunosupresor de las CSM. Los cambios de estado inflamatorios durante el curso de una respuesta inmune, se ven afectados por el tiempo y los activadores del sistema inmunológico entre otros factores. Las CSM pueden alterar la balanza entre la inflamación y la inmunosupresión de modo que las CSM pueden tanto promover una respuesta inmune como inhibirla en función de la dinámica de la inflamación y en función del grado de activación del sistema inmune, los tipos de citocinas inflamatorias presentes y los efectos de los inmunosupresores. La capacidad inmunomoduladora de las CSM en respuesta a las distintas fluctuaciones de los niveles de inflamación depende en gran medida de las concentraciones de IFN- $\gamma$ y TNF para evaluar la concentración de citoquinas que regulan la función inmunosupresora suscitada por las $\mathrm{CSM}^{283-285}$ (Fig. $55)$.

Las células Treg producen citoquinas inmunosupresoras como TGF- $\beta$ que a menudo se detectan en entornos inflamatorios, en el que se cree que ejerce un papel de contrapunto $^{286}$. Curiosamente, las CSM expresan receptores I y II de TGF- $\beta$, que podrían modular diferenciación y las capacidades regenerativas de estas células ${ }^{287,288}$. Sin embargo, cuando se estimula a las CSM con TGF- $\beta 1$ o TGF- $\beta 2$ junto con IFN- $\gamma$ y TNF, éstas son menos inmunosupresoras ${ }^{289}$. La capacidad inmunosupresora de las CSM puede ser inhibida por la adición de IL- $10^{290}$, cuya acción suele ser sinérgica a la de TGF- $\beta^{291}$. Estos datos revelan la otra cara de la moneda: citoquinas que normalmente ejercen un efecto inmunosupresor pueden convertirse en potenciadores de la respuesta inmune a través de sus efectos ejercidos sobre las CSM. Varios grupos han puesto de manifiesto que las CSM pueden inducir la generación de células Treg ${ }^{292}$. Los efectos que NO y IDO producidos por las CSM en las generación de células Treg generación 
merece una investigación adicional, especialmente en el contexto de otros factores importantes en un ambiente inflamatorio (Fig. 56).

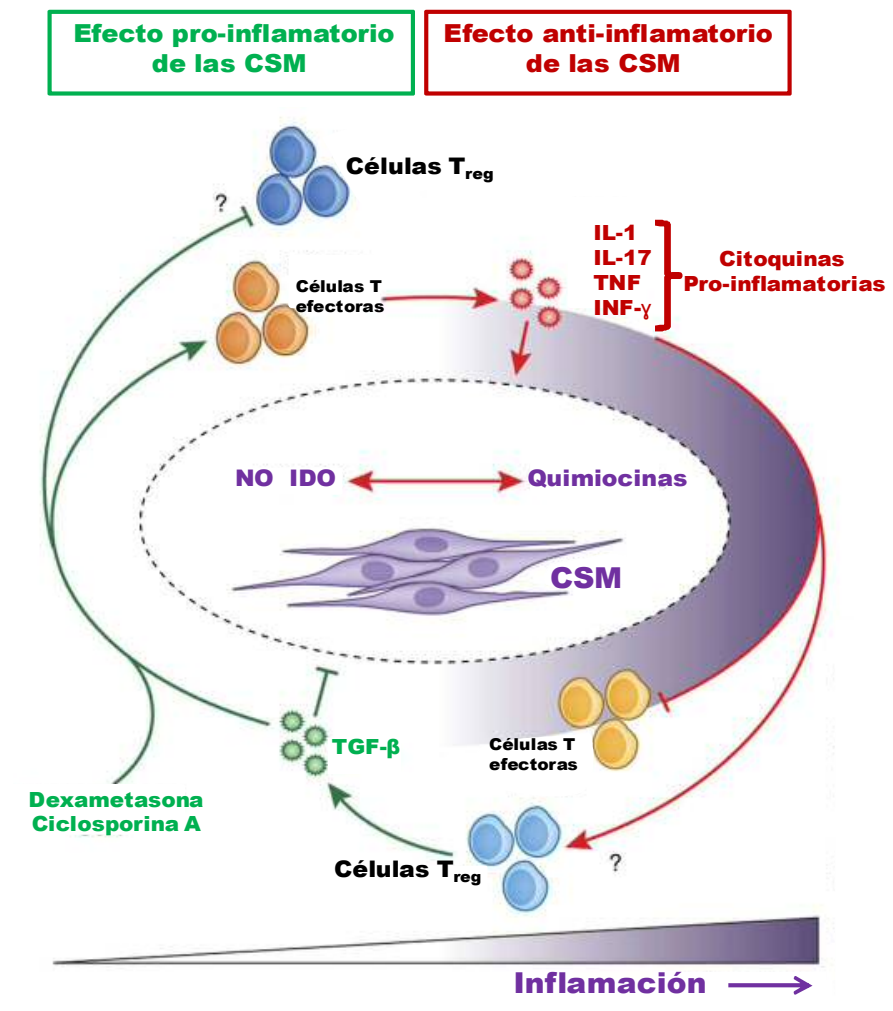

Fig. 56. Esquema del efecto pro-inflamatorio y anti-inflamatorio de las CSM. Adaptado de Wang Y y cols. Nature Immunology. 15(11): 1009-1016. 2014

\subsubsection{Correlación entre la actividad inflamatoria y la eficacia de la terapia}

\section{con hCSM}

Actualmente las CSM se emplean en el tratamiento de diversas enfermedades.

Su administración se fundamenta en las investigaciones previas que se llevan a cabo en modelos animales y ensayos clínicos. El efecto de las CSM en la mayoría de los casos se debe a su potente capacidad inmunorreguladora. Resulta evidente que es necesaria una estimulación inflamatoria adecuada para obtener el efecto inmunosupresor de las CSM. Por tanto, la monitorización del estado inflamatorio de los pacientes en el momento en que se infunden las CSM puede contribuir a la optimización de las terapias

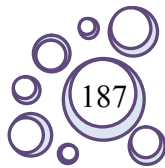


basadas en CSM, y se debe trabajar en el desarrollo de biomarcadores que den cuenta del estado inflamatorio.

Para el uso terapéutico de las CSM es importante conocer el origen de los tejidos a partir de los cuales se extraen las CSM, su origen autólogo o alogénico. Los pases que se hacen al cultivo y el tiempo óptimo de cultivo antes de la administración de las CSM. También resultan trascendentes los parámetros de selección del paciente, los datos clínicos, las cuestiones éticas y las regulaciones administrativas.

Pero además de lo anterior, las condiciones inflamatorias determinan el destino biológico de las CSM. La falta de uniformidad en la respuesta a una terapia con CSM se debe en parte a la variabilidad en la inflamación, ya que se necesita una mínima inflamación para permitir la inmunosupresión ejercida por las CSM. La respuesta fisiológica a una lesión en un tejido se puede dividir en tres fases: inflamatoria, reparadora y remodeladora (Fig. 57). Durante este proceso, el estado inflamatorio (definido como los tipos y concentraciones de citocinas y células del sistema inmune presentes) cambia considerablemente: la influencia proinflamatoria es dominante durante la fase de inflamación y disminuye en las fases reparadora y remodeladora. Sólo en presencia de una inflamación firme resulta eficaz un tratamiento con CSM. Por lo tanto, sería posible optimizar la eficacia de la terapia con CSM mediante la evaluación del estado inflamatorio de los pacientes para determinar el momento idóneo para la administración celular ${ }^{273}$. Además, es posible que un pre-tratamiento o pre-estimulación de las CSM con las citocinas inflamatorias apropiadas antes de la administración in vivo pueda mejorar la eficacia de los tratamientos basados en $\operatorname{CSM}^{278,293}$. Los cambios en la intensidad de la inflamación alteran sustancialmente los efectos de la inmunomodulación mediada por las CSM, que se traduce en una correlación variable 
entre el grado de la intensidad de la inflamación y la eficacia del tratamiento ejercido por las CSM.

Sin duda, la identificación de marcadores específicos de CSM, la investigación sobre las CSM residente en los tejidos sin duda traerá una nueva visión sobre el papel de estas células en las diversas situaciones fisiopatológicas. Además, puede que sea posible explotar la plasticidad de la función inmunorreguladora de las CSM para adaptar los tratamientos clínicos a unas condiciones inflamatorias específicas. Esto permitirá que los protocolos clínicos basados en CSM pudieran optimizarse para lograr la modulación apropiada en función de las respuestas inflamatorias en las diferentes etapas de la progresión de una enfermedad.

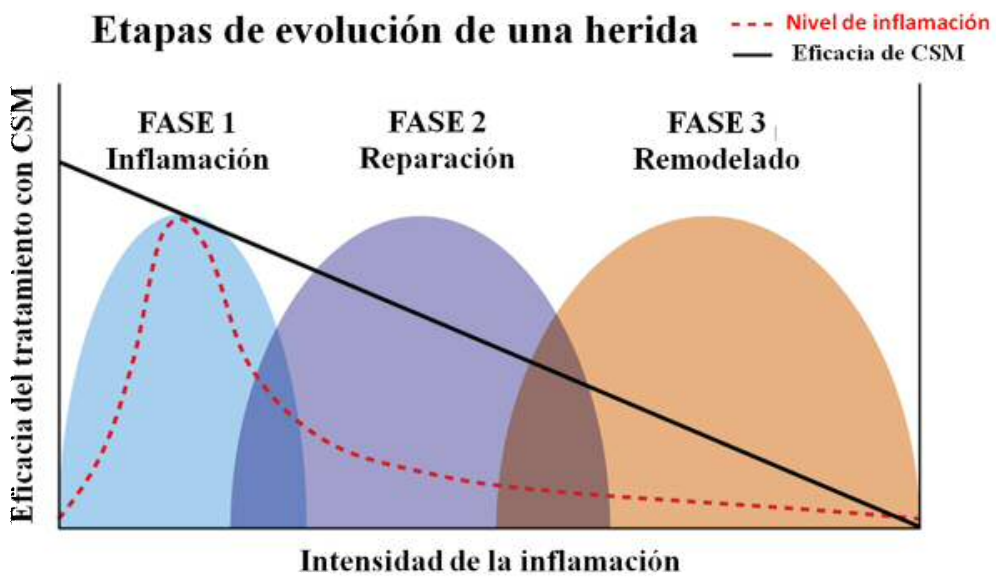

Fig. 57. Estado inflamatorio y la eficacia de la terapia con CSM. Adaptado de Wang Y et al. Nature Immunology. 15(11): 1009-1016. 2014. 



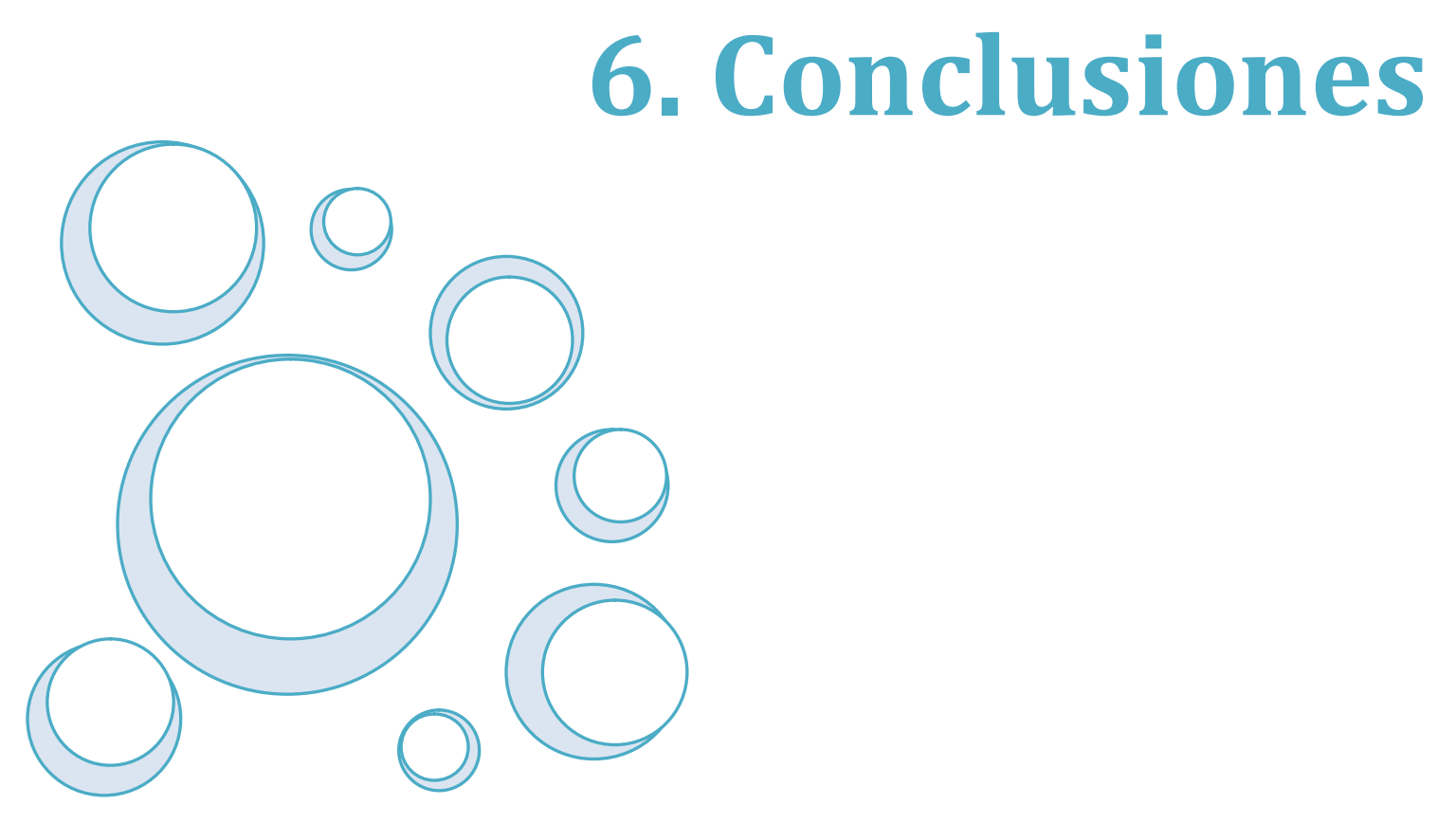



De acuerdo con los objetivos e hipótesis planteados en este Trabajo de Tesis Doctoral y como consecuencia de los resultados obtenidos y de su posterior discusión, hemos llegado a las siguientes conclusiones:

Primera: El modelo murino de EICRo desarrollado y validado en el presente estudio reproduce la xeroftalmia ocular observada en los pacientes con EICRo, confirmando la idoneidad de este modelo experimental para el estudio de la fisiopatología del síndrome de ojo seco que puede permitir la evaluación de nuevas estrategias terapéuticas y que se asienta en los siguientes hallazgos fundamentales:

1. A. En los ratones a los que se generó la EICRo, se ha podido verificar cambios fisiopatológicos de la enfermedad tanto a nivel palpebral como glandular, objetivándose una infiltración linfocitaria de la glándula lagrimal de linfocitos $\mathrm{CD3}+/ \mathrm{CD} 45+/ \mathrm{H} 2 \mathrm{Db}+$ de origen alogénico.

2. B. Se han evaluado las modificaciones de parámetros clínicos objetivables de la enfermedad, observándose una disminución del volumen de lágrima así como un aumento de osmolaridad de la misma en los ratones donde se generó la EICRo.

Segunda: En los ratones con EICRo a los que se les administró hCSM por vía subconjuntival se ha comprobado mediante técnicas de bioluminiscencia su permanencia durante un periodo de al menos 5 semanas después de su administración.

Tercera: Mediante técnicas de inmunohistoquímica y empleando un doble marcaje con GFP y mitocondria humana se ha podido verificar la presencia de hCSM 
transducidas en glándula lagrimal y párpado transcurridas 4 semanas de su administración por vía subconjuntival.

Cuarta: En los ratones tratados con hCSM por vía subconjuntival transcurridos 10 días de la generación de la EICRo, se ha observado, mediante técnicas de citometría de flujo, una significativa disminución del porcentaje de infiltración linfoide alogénica $\left(\mathrm{CD}^{+} / \mathrm{CD} 45^{+} / \mathrm{H} 2 \mathrm{D}^{\mathrm{b}+}\right)$ en la glándula lagrimal.

Quinta: Los animales con EICRo tratados con hCSM por vía subconjuntival transcurridos 10 días de la generación de la EICRo, recuperan los valores de volumen de lágrima y de osmolaridad de los grupos controles sanos. Debido a la desfavorable evolución natural de la enfermedad sistémica, no se ha podido constatar una significativa mejoría de estos parámetros clínicos en fases más avanzadas de la enfermedad.

Sexta y última: El tratamiento de la EICRo con hMSC administradas por vía subconjuntival podría ser una estrategia terapéutica efectiva debido a las propiedades reparadoras, anti-inflamatorias e inmunomoduladoras de las hMSC que se han objetivado en ratones a los que previamente se les ha generado la enfermedad. 


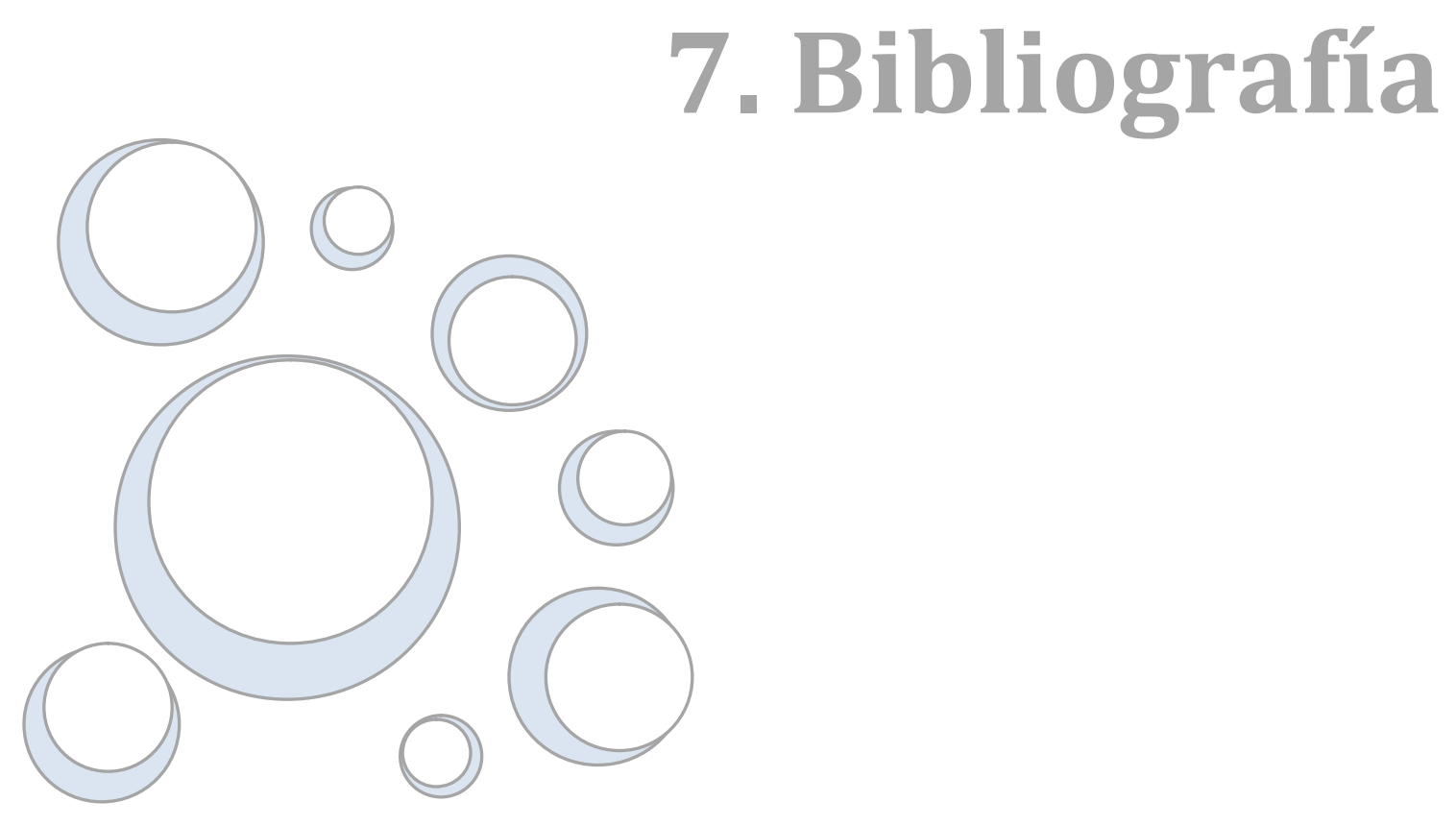



1. Rouvière H., Delmas A. Anatomía humana. Descriptiva, topográfica y funcional. Tomo 1. Cabeza y cuello. $11^{\circ}$ Edición. 2005. Masson. Barcelona.

2. Weingeist TA: The glands of the ocular adnexa. In Zinn KM, editor: Ocular structure for the clinician. 1973, Little, Brown. Boston.

3. Jakobiec FA, Iwamoto T: The ocular adnexa: lids, conjunctiva, and orbit. In Fine BS, Yanoff M, editors: Ocular histology. $2^{\text {nd }}$ Edition. 1979. Harper \& Row. New York.

4. Iwamoto T, Jakobiec FA: Lacrimal glands. In Tasman W, Jaeger EA, Editors: Duane's foundations of clinical ophthalmology, vol 1. 1994. Lippincott. Philadelphia.

5. Warwick R: Eugene Wolff's anatomy of the eye and orbit. $7^{\text {th }}$ Edition. 1976. Saunders. Philadelphia.

6. Gipson IK, Yankauckas M, Spurr-Michaud SJ, Tisdale AS, Rinehart W. Characteristics of a glycoprotein in the ocular surface glycocalyx. Invest Ophthalmol Vis Sci 1992; 33:218-27.

7. Nichols B, Dawson CR, Togni B. Surface features of the conjunctiva and cornea, Invest Ophthalmol Vis Sci 1983; 24:570-6.

8. Diebold Y, Rios JD, Hodges RR, Rawe I, Dartt DA. Presence of nerves and their receptors in mouse and human conjunctival goblet cells. Invest Ophthalmol Vis Sci $2001 ; 42: 2270-82$

9. Steuhl KP, Sitz U, Knorr M, Thanos S, Thiel HJ . Age-dependent distribution of Langerhans cells within human conjunctival epithelium. Ophthalmologe 1995; 92:21-5. 10. Hogan MJ, Alvarado JA: Histology of the human eye. 1971. Saunders. Philadelphia. 11. Allensmith MR, Greiner JV, Baird RS. Number of inflammatory cells in the normal conjunctiva, Am J Ophthalmol 1978; 86:250-9. 
12. Jakobiec FA, Iwamoto T. Ocular adnexa: introduction to lids, conjunctiva, and orbit. In Tasman W, Jaeger EA, editors: Duane's foundations of clinical ophthalmology, vol 1. 1994. Lippincott. Philadelphia.

13. Knop N, Knop E. Conjunctiva-associated lymphoid tissue in the human eye, Invest Ophthalmol Vis Sci 2000; 41:1270-9.

14. Reiger G. The importance of the precorneal tear film for the quality of optical imaging, Br J Ophthalmol 1992; 76:157-8.

15. Lemp MA, Wolfley DE. The lacrimal apparatus. In Hart WM Jr, editor: Adler's physiology of the eye. $9^{\text {th }}$ Edition. 1992. Mosby. St Louis.

16. Mishima S, Maurice DM. The effect of normal evaporation on the eye. Exp Eye Res $1961 ; 1: 46-52$.

17. Lemp MA, Holly FJ, Iwata S. The precorneal tear film, Arch Ophthalmol. 1970; 83:89-94.

18. Watanabe H, Fabricant M, Tisdale AS, Spurr-Michaud SJ, Lindberg K, Gipson IK. Human corneal and conjunctival epithelia produce a mucin-like glycoprotein for the apical surface, Invest Ophthalmol Vis Sci 1995; 36:337-44.

19. Ehlers N. The thickness of the precorneal tear film. Factors in spreading and maintaining a continuous tear film over the corneal surface, Acta Ophthalmol 1965; 8:92.

20. Prydal JI, Artal P, Woon H, Campbell FW. Study of human precorneal tear film thickness and structure using laser interferometry. Invest Ophthalmol Vis Sci 1992; 33: 2006-11.

21. Prydal JI, Campbell FW: Study of precorneal tear film thickness and structure by interferometry and confocal microscopy. Invest Ophthalmol Vis Sci 1992; 33:19962005 . 
22. Peral A, Pintor J. Ocular mucin visualization by confocal laserscanning microscopy, Cornea 2008; 27:395-401.

23. Dartt DA, Hodges RR, Zoukhri D. Tears and their secretion. In The biology of the eye. Fischbarg J, vol 10. 2006. Elsevier. Amsterdam.

24. Martino R, Caballero MD, Pérez-Simón JA, Canals C, Solano C, Urbano-Ispízua A, Bargay J, Léon A, Sarrá J, Sanz GF, Moraleda JM, Brunet S, San Miguel J, Sierra J. Evidence for a graft-versus-leukemia effect after allogeneic peripheral blood stem cell transplantation with reduced-intensity conditioning in acute myelogenous leukemia and myelodysplastic syndromes. Blood 2002; 100: 2243-5.

25. Pérez-Simón JA, Martino R, Alegre A, Tomás JF, De Leon A, Caballero D, Sureda A, Sierra J, San Miguel JF. Chronic but not acute graft-versus-host disease improves outcome in multiple myeloma patients after non-myeloablative allogeneic transplantation. Br J Haematol 2003; 121:104-8.

26. Arora M, Klein JP, Weisdorf DJ, Hassebroek A, Flowers ME, Cutler CS, UrbanoIspizua A, Antin JH, Bolwell BJ, Boyiadzis M, Cahn JY, Cairo MS, Isola L, Jacobsohn DA, Jagasia M, Klumpp TR, Lee SJ, Petersdorf EW, Santarone S, Gale RP, Schouten HC, Spellman S, Wingard JR, Horowitz MM, Pavletic SZ. Chronic GVHD risk score: a Center for International Blood and Marrow Transplant Research analysis. Blood 2011; 117:6714-20.

27. Bensinger WI, Martin PJ, Storer B, Clift R, Forman SJ, Negrin R, Kashyap A, Flowers ME, Lilleby K, Chauncey TR, Storb R, Appelbaum FR. Transplantation of bone marrow as compared with peripheral-blood cells from HLA-identical relatives in patients with hematologic cancers. N Engl J Med 2001;344:175-81.

28. Blaise D, Kuentz M, Fortanier C, Bourhis JH, Milpied N, Sutton L, Jouet JP, Attal M, Bordigoni P, Cahn JY, Boiron JM, Schuller MP, Moatti JP, Michalle M. 
Randomized trial of bone marrow versus lenograstim-primed blood cell allogeneic transplantation in patients with early-stage leukemia: a report from the Societe Francaise de Greffe de Moelle. J Clin Oncol 2000; 18:537-46.

29. Heldal D, Tjønnfjord G, Brinch L, Albrechtsen D, Egeland T, Steen R, Solheim BG, Evensen SA. A randomised study of allogeneic transplantation with stem cells from blood or bone marrow. Bone Marrow Transplant 2000;25:1129-36.

30. Jagasia M, Arora M, Flowers M. Risk-factors for acute graft-versus-host disease and survival after hematopoietic cell transplantation from siblings and unrelated donors: An analysis of the CIBMTR. Blood (ASH Annu Meet Abstracts). 2010;116:897.

31. Ferrara JL, Levine JE, Reddy P, Holler E. Graft-versus-host disease. Lancet 2009;373:1550-61.

32. Sullivan KM. Graft-versus-host disease, in Forman SJ (ed). Thomas' Hematopoietic Cell Transplantation. 1999. Wiley-Blackwell. Oxford, UK.

33. Solano C, Martínez C, Carreras E. Diagnóstico y estudio de extensión de la enfermedad injerto contra huésped crónica. En: Manual de la Enfermedad Injerto Contra Huésped Crónica 2009; 1:5-11.

34. Hill GR, Crawford JM, Cooke KR. Total body irradiation and acute graft-versushost disease: the role of gastrointestinal damage and inflammatory cytokines. Blood 1997;90: 3204-13.

35. Hill GR, Ferrara JL. The primacy of the gastrointestinal tract as a target organ of acute graft-versus-host disease: rationale for the use of cytokine shields in allogeneic bone marrow transplantation. Blood 2000; 95:2754-9.

36. Matzinger P. The danger model: a renewed sense of self. Science $2002 ; 296: 301-5$

37. Xun CQ, Thompson JS, Jennings CD, Brown SA, Widmer MB. Effect of total body irradiation, busulfan-cyclophosphamide, or cyclophosphamide conditioning on 
inflammatory cytokine release and development of acute and chronic graft-versus- host disease in H-2-incompatible transplanted SCID mice. Blood 1994; 83:2360-7

38. Dustin ML. Role of adhesion molecules in activation signaling in T lymphocytes. $\mathrm{J}$ Clin Immunol 2001; 21: 258-63.

39. Ferrara JLM. Graft-versus-Host Disease. 1999. Saunders Company. Philadelphia.

40. Cohen JL, Boyer $\mathrm{O}$. The role of $\mathrm{CD} 4 \mathrm{pCD} 25$ hi regulatory $\mathrm{T}$ cells in the physiopathogeny of graft-versus-host disease. Curr Opin Immunol 2006; 18:580-5.

41. Lin MT, Storer B, Martin PJ Tseng LH, Gooley T, Chen PJ, Hansen JA. Relation of an interleukin-10 promoter polymorphism to graft-versus-host disease and survival after hematopoietic-cell transplantation. N Engl J Med 2003; 349:2201- 10.

42. Welniak LA, Blazar BR, Murphy WJ. Immunobiology of allogeneic hematopoietic stem cell transplantation. Annu Rev Immunol 2007; 25:139-70.

43. Soiffer R. Immune modulation and chronic graft-versus-host disease. Bone Marrow Transplant 2008;42: 566-9.

44. Jamil MO. State-of the-art acute and chronic GVHD treatment. Int J Hematol 2015; 101:452-66.

45. Vogelsang GB, Lee L, Bensen-Kennedy DM. Pathogenesis and treatment of graftversus-host disease after bone marrow transplant. Annu Rev Med 2003; 54:29-52.

46. Inamoto Y, Martin PJ, Storer BE, Palmer J, Weisdorf DJ, Pidala J, Flowers ME, Arora M, Jagasia M, Arai S, Chai X, Pavletic SZ, Vogelsang GB, Lee SJ. Association of severity of organ involvement with mortality and recurrent malignancy in patients with chronic graft-versus-host disease. Haematologica 2014; 99:1618-23.

47. Ferrara JL, Deeg HJ. Graft-versus-host disease. N Eng1 J Med 1991;324:667-74.

48. Nevo S, Enger C, Swan V, Wojno KJ, Fuller AK, Altomonte V, Braine HG, Noga SJ, Vogelsang GB. Acute bleeding after allogeneic bone marrow transplantation: 
association with graft versus host disease and effect on survival. Transplantation 1999;67:681-9.

49. Bray LC, Carey PJ, Proctor SJ. Ocular complications of bone marrow transplantation. Br J Ophthalmol 1991;75: 611-4.

50. Franklin RM, Kenyon KR, Tutschka PJ, Saral R, Green WR, Santos GW. Ocular manifestations of graft-vs-host disease. Ophthalmology 1983;90:4-13.

51. Hirst LW, Jabs DA, Tutschka PJ, Green WR, Santos GW. The eye in bone marrow transplantation. I. Clinical study. Arch Ophthalmol 1983;101:580-4.

52. Thomas E, Storb R, Clift RA, Fefer A, Johnson FL, Neiman PE, Lerner KG, Glucksberg H, Buckner CD. Bone-marrow transplantation (first of two parts). N Engl J Med. 1975;292:832-43.

53. Sales CS, Johnston LJ, Ta CN. Long-term clinical course of dry eye in patients with chronic graft-versus-host disease referred for eye examination. Cornea 2011;30:143-9

54. Rojas B, Cuhna R, Zafirakis P, Ramirez JM, Lizan-García M, Zhao T, Foster CS. Cell populations and adhesion molecules expression in conjunctiva before and after bone marrow transplantation. Exp Eye Res 2005;81:313-25.

55. Aronni S, Cortes M, Sacchetti M, Lambiase A, Micera A, Sgrulletta R, Bonini S.. Upregulation of ICAM-1 expression in the conjunctiva of patients with chronic graftversus-host disease. Eur J Ophthalmol 2006;16:17-23.

56. Ogawa Y, Okamoto S, Wakui M, Watanabe R, Yamada M, Yoshino M, Ono M, Yang HY, Mashima Y, Oguchi Y, Ikeda Y, Tsubota K. Dry eye after hematopoietic stem cell transplantation. Br J Ophthalmol 1999; 83: 1125-30.

57. Mencucci R, Rossi Ferrini C, Bosi A, Volpe R, Guidi S, Salvi G. Ophthalmological aspects in allogenic bone marrow transplantation : Sjögren Like syndrome in graftversus-hodt-disease. Eur J Ophthalmol 1997; 7:13-8. 
58. Ogawa Y, Kuwana M. Dry eye as a major complication associated with chronic graft-versus-host disease after hematopoietic stem cell transplantation. Cornea 2003; 22:19-27.

59. Claes K, Kestelyn P. Ocular manifestations of graft-versus-host disease following bone marrow transplantation. Bull Soc Belge Ophtalmol 2000; 277: 21-6.

60. Atkinson K. Review: Chronic graft-versus-host disease. Bone Marrow Transplant 1990; 5: 69-82.

61. Ogawa Y, Kuwana M, Yamazaki K, Mashima Y, Yamada M, Mori T, Okamoto S, Oguchi Y, Kawakami Y. Periductal area as the primary site for T-cell activation in lacrimal gland chronic graft-versus-host disease. Invest Ophthalmol Vis Sci 2003;44:1888-96.

62. Yamazaki K, Eyden BP. Ultrastructural and immunohistochemical observations on intralobular fibroblasts of human breast, with observations on the CD34 antigen. J Submicrosc Cytol Pathol 1995;27:309-23.

63. Yamazaki K, Eyden BP. Ultrastructural and immunohistochemical studies of intralobular fibroblasts in human submandibular gland: the recognition of a "CD34 positive reticular network" connected by gap junctions. J Submicrosc Cytol Pathol 1996;28:471-483.

64. Yamazaki K, Eyden BP. Intrafollicular fibroblasts in human thyroid gland: the recognition of a CD34 positive stromal cell network communicated by gap junctions and terminated by autonomic nerve endings. J Submicrosc Cytol Pathol 1997;29:461 476.

65. Hassan AS, Clouthier SG, Ferrara JL, Stepan A, Mian SI, Ahmad AZ, Elner VM. Lacrimal gland involvement in graft-versus-host disease: a murine model. Invest Ophthalmol Vis Sci 2005;46:2692-7. 
66. Sale GE, Shulman HM, Schubert MM, Sullivan KM, Kopecky KJ, Hackman RC, Morton TH, Storb R, Thomas ED. Oral and ophthalmic pathology of graft versus host disease in man: predictive value of the lip biopsy. Hum Pathol 1981;12:1022-30.

67. Ghadially F. Cell membrane and coat. In: Ghadially F, ed. Ultrastructural Pathology of the Cell and Matrix. Oxford: Butterworth-Heinemann; 1996:1171-9.

68. Pandey JP, LeRoy EC. Human cytomegalovirus and the vasculopathies of autoimmune disease (especially scleroderma), allograft rejection, and coronary restenosis. Arthritis Rheum 1998;41:10-15.

69. Ogawa Y, Yamazaki K, Kuwana M, Mashima Y, Nakamura Y, Ishida S, Toda I, Oguchi Y, Tsubota K, Okamoto S, Kawakami Y. A significant role of stromal fibroblasts in rapidly progressive dry eye in patients with chronic GVHD. Invest Ophthalmol Vis Sci 2001;42:111-9.

70. Ogawa Y, Shimmura S, Kuwana M. Inflammation and pathogenic fibrosis in human ocular chronic graft versus host disease. Inflammation and regeneration 2008;28:52936.

71. Tsubota K. The importance of Schirmer test with nasal stimulation. Am J Ophthalmol 1991;111:106-8.

72. Shimazaki J, Sakata M, Tsubota K. Ocular surface changes and discomfort in patients with meibomian gland dysfunction. Arch Ophthalmol 1995;113:1266-70.

73. Shimazaki J. Definition and criteria of dry eye. Ganka. 1995;37:765-70.

74. Lemp MA. Report of the National Eye Institute/Industry Workshop on Clinical Trials in Dry Eyes. CLAO J 1995;21:221-32.

75. Ebato B, Friend J, Thoft RA. Comparison of limbal and peripheral human corneal epithelium in tissue culture. Invest Ophthalmol Vis Sci 1988;29:1533-7. 
76. Arffa R. Enfermedades de la cornea. 4ª Edición.1999. Madrid: Moby División de Times Mirror de España, S.A.

77. Thoft RA, Wiley LA, Sundarraj N. The multipotential cells of the limbus. Eye (Lond) 1989;3:109-13.

78. Benítez del Castillo J, Durán de la Colina, JA., Rodríguez Ares, MT. Superficie Ocular. Madrid: Sociedad Española de Oftalmología; 2004.

79. Bray LC, Carey PJ, Proctor SJ, Evans RG, Hamilton PJ. Ocular complications of bone marrow transplantation. Br J Ophthalmol 1991;75:611-4.

80. Franklin RM, Kenyon KR, Tutschka PJ, Saral R, Green WR, Santos GW. Ocular manifestations of graft-vs-host disease. Ophthalmology 1983;90:4-13.

81. Jack MK, Jack GM, Sale GE, Shulman HM, Sullivan KM. Ocular manifestations of graft-versus-host disease. Arch Ophthalmol 1983;101:1080-4.

82. Kim SK. Ocular Graft versus Host Disease. St Louis; 2004.

83. Arocker-Mettinger E, Skorpik F, Grabner G, Hinterberger W, Gadner H . Manifestations of graft-versus host disease following allogenic bone marrow transplantation. Eur J Ophthalmol 1991;1:28-32.

84. Bernauer W, Gratwohl A, Keller A, Daicker B. Microvasculopathy in the ocular fundus after bone marrow transplantation. Ann Intern Med. 1991;115:925-30.

85. Coskuncan NM, Jabs DA, Dunn JP, Haller JA, Green WR, Vogelsang GB, Santos GW. The eye in bone marrow transplantation. VI. Retinal complications. Arch Ophthalmol 1994;112:372-9.

86. Gloor B, Gratwohl A, Hahn H, Kretzschmar S, Robert Y, Speck B, Daicker B.. Multiple cotton wool spots following bone marrow transplantation for treatment of acute lymphatic leukaemia. Br J Ophthalmol 1985;69: 320-5. 
87. Tichelli A, Duell T, Weiss M, Socié G, Ljungman P, Cohen A, van Lint M, Gratwohl A, Kolb HJ. Late-onset keratoconjunctivitis sicca syndrome after bone marrow transplantation: incidence and risk factors. European Group or Blood and Marrow Transplantation (EBMT) Working Party on Late Effects. Bone Marrow Transplant 1996;17: 1105-11.

88. Anderson NG, Regillo C. Ocular manifestations of graft versus host disease. Curr Opin Ophthalmol 2004;15:503-7.

89. Jea Chang-Strepka. Videokeratoscopic indices in chronic ocular graft versus host disease (GVHD). Invest Ophthalmol Vis Sci 2009;50:2610.

90. Shikari H., Antin J, Reza D. Ocular Graft-versus-Host Disease: A Review. Surv Ophthalmol 2013;58:233-51.

91. Jabs DA, Wingard J, Green WR, Farmer ER, Vogelsang G, Saral R. The eye in bone marrow transplantation. III. Conjunctival graft-vs-host disease. Arch Ophthalmol 1989;107:1343-8.

92. Robinson MR, Lee SS, Rubin BI, Wayne AS, Pavletic SZ, Bishop MR, Childs R, Barrett AJ, Csaky KG. Topical corticosteroid therapy for cicatricial conjunctivitis associated with chronic graft-versus-host disease. Bone Marrow Transplant 2004;33:1031-5.

93. Cocho L, Fernández I, Calonge M, Martínez V, González-García MJ, Caballero D, López-Corral L, García-Vázquez C, Vázquez L, Stern ME, Enríquez-de-Salamanca A. Biomarkers in ocular chronic graft versus host disease: tear cytokine- and chemokinebased predictive model. Invest Ophthalmol Vis Sci 2016;57:746-58.

94. Cocho L, Fernández I, Calonge M, Martínez V, González-García MJ, Caballero D, López-Corral L, García-Vázquez C, Vázquez L, Stern ME, Enríquez-de-Salamanca A. 
Gene expression-based predictive models of graft versus host disease-associated dry eye. Invest Ophthalmol Vis Sci 2015;56:4570-81.

95. Weng Y, Siciliano SJ, Waldburger KE, Sirotina-Meisher A, Staruch MJ, Daugherty BL, Gould SL, Springer MS, DeMartino JA. Binding and functional properties of recombinant and endogenous CXCR3 chemokine receptors. J Biol Chem 1998;273:18288- 91.

96. Wysocki CA, Panoskaltsis-Mortari A, Blazar BR, Serody JS. Leukocyte migration and graft-versus host disease. Blood 2005;105:4191-9.

97. Westekemper H, Meller S, Citak S, Schulte C, Steuhl KP, Homey B, Meller D . Differential chemokine expression in chronic GVHD of the conjunctiva. Bone Marrow Transplant 2010;45:1340-6.

98. Pflugfelder SC, Jones D, Ji Z, Afonso A, Monroy D. Altered cytokine balance in the tear fluid and conjunctiva of patients with Sjögren's syndrome keratoconjunctivitis sicca. Curr Eye Res 1999;19:201-11.

99. Lam H, Bleiden L, de Paiva CS, Farley W, Stern ME, Pflugfelder SC. Tear cytokine profiles in dysfunctional tear syndrome. Am J Ophthalmol 2009;147: 198-205.

100. Enríquez-de-Salamanca A, Castellanos E, Stern ME, Fernández I, Carreño E, García-Vázquez C, Herreras JM, Calonge M.. Tear cytokine and chemokine analysis and clinical correlations in evaporative-type dry eye disease. Mol Vis 2010;16:862-73. 101. Massingale ML, Li X, Vallabhajosyula M, Chen D, Wei Y, Asbell PA. Analysis of inflammatory cytokines in the tears of dry eye patients. Cornea 2009;28:1023-7.

102. Lee SY, Han SJ, Nam SM, Yoon SC, Ahn JM, Kim TI, Kim EK, Seo KY . Analysis of tear cytokines and clinical correlations in Sjögren syndrome dry eye patients and non-Sjögren syndrome dry eye patients. Am J Ophthalmol 2013;156:24753. 
103. Schots R, Kaufman L, Van Riet I. Proinflammatory cytokines and their role in the development of major transplant-related complications in the early phase after allogeneic bone marrow transplantation. Leukemia 2003;17:1150-6.

104. Paczesny S, Krijanovski OI, Braun TM, Choi SW, Clouthier SG, Kuick R, Misek DE, Cooke KR, Kitko CL, Weyand A, Bickley D, Jones D, Whitfield J, Reddy P, Levine JE, Hanash SM, Ferrara JL. A biomarker panel for acute graft-versus-host disease. Blood 2009;113:273-8.

105. Levine JE, Logan BR, Wu J, Alousi AM, Bolaños-Meade J, Ferrara JL, Ho VT, Weisdorf DJ, Paczesny S . Acute graft-versus-host disease biomarkers measured during therapy can predict treatment outcomes: a Blood and Marrow Transplant Clinical Trials Network study. Blood 2012;119:3854-60.

106. Riemens A, Stoyanova E, Rothova A, Kuiper J. Cytokines in tear fluid of patients with ocular graft-versus-host disease after allogeneic stem cell transplantation. Mol Vis 2012;18:797-802.

107. Kishimoto T. Interleukin-6 and its receptor in autoimmunity. J Autoimmun 1992; 5:123-32.

108. Miossec P, Korn T, Kuchroo VK. Interleukin-17 and type 17 helper T cells. N Engl J Med 2009; 361:888-98.

109. Min CK, Lee WY, Min DJ, Lee DG, Kim YJ, Park YH, Kim HJ, Lee S, Kim DW, Lee JW, Min WS, Kim CC. The kinetics of circulating cytokines including IL-6, TNFalpha, IL-8 and IL-10 following allogeneic hematopoietic stem cell transplantation. Bone Marrow Transplant 2001; 28:935-40.

110. De Paiva CS, Chotikavanich S, Pangelinan SB, Pitcher JD, Fang B, Zheng X, Ma P, Farley WJ, Siemasko KF, Niederkorn JY, Stern ME, Li DQ, Pflugfelder SC. IL-17 disrupts corneal barrier following desiccating stress. Mucosal Immunol 2009; 2:243-53. 
111. Serody JS, Hill GR. The IL-17 Differentiation Pathway and its Role in Transplant Outcome. Biol Blood Marrow Transplant 2012; 18:S56-61.

112. Tawara I, Koyama M, Liu C, Toubai T, Thomas D, Evers R, Chockley P, Nieves E, Sun Y, Lowler KP, Malter C, Nishimoto N, Hill GR, Reddy P. Interleukin-6 modulates graft-versus-host responses after experimental allogeneic bone marrow transplantation. Clin Cancer Res 2011; 17:77-88.

113. Jung JW, Han SJ, Song MK, Kim TI, Kim EK, Min YH, Cheong JW, Seo KY. Tear cytokines as biomarkers for chronic graft-versus-host disease. Biol Blood Marrow Transplant 2015;21:2079-85.

114. Von Thun Und Hohenstein-Blaul N, Funke S, Grus FH. Tears as a source of biomarkers for ocular and systemic diseases. Exp Eye Res 2013;117:126-137.

115. Kim SK, Couriel D, Ghosh S. Ocular graft vs. host disease experience from MD Anderson Cancer Center: Newly described clinical spectrum and new approach to the management of stage III and IV ocular GVHD. Biol Blood Marrow Transplant 2006;12:49-50.

116. Balaram M, Schaumberg DA, Dana MR. Efficacy and tolerability outcomes after punctal occlusion with silicone plugs in dry eye syndrome. Am J Ophthalmol 2001;131:30-6.

117. Kiang E, Tesavibul N, Yee R, Kellaway J, Przepiorka D. . The use of topical cyclosporin A in ocular graft-versus-host-disease. Bone Marrow Transplant. 1998;22:147-51.

118. Lelli GJ Jr, Musch DC, Gupta A, Farjo QA, Nairus TM, Mian SI. Ophthalmic cyclosporine use in ocular GVHD. Cornea. 2006;25:635-8. 
119. Barber LD, Pflugfelder SC, Tauber J, Foulks GN.. Phase III safety evaluation of cyclosporine $0.1 \%$ ophthalmic emulsion administered twice daily to dry eye disease patients for up to 3 years. Ophthalmology 2005;112:1790-4.

120. Stevenson D, Tauber J, Reis BL. Efficacy and safety of cyclosporin A ophthalmic emulsion in the treatment of moderate-to-severe dry eye disease: a dose-ranging, randomized trial. The Cyclosporin A Phase 2 Study Group. Ophthalmology 2000;107:967-74.

121. Pfau B, Kruse FE, Rohrschneider K, Zorn M, Fiehn W, Burk RO, Völcker HE . Comparison between local and systemic administration of cyclosporin $\mathrm{A}$ on the effective level in conjunctiva, aqueous humor and serum. Ophthalmologe 1995;92:8339.

122. Shikarh H, Amparo F, Dastjerdi M, et al. Effects of topical IL-1Ra in signs and symptoms in eye dry disease in patients with ocular GHVD. Poster in ARVO 2012. Fort Lauderdale, FL, May 5-10, 2012.

123. López G, Kyriakou D, Rodríguez G, Álvarez-Morujo G, Hérnandez E. Tacrólimus tópico como tratamiento de rechazo corneal agudo en queraoplastia de origen herpético: a propósito de un caso. $38^{\circ}$ Reunión Sociedad Gallega de Oftalmología. 2012.

124. Murphy PT, Sivakumaran M, Fahy G, Hutchinson RM. Successful use of topical retinoic acid in severe dry eye due to chronic graft-versus-host disease. Bone Marrow Transplant 1996;18:641-2.

125. Ogawa Y, Okamoto S, Mori T, Yamada M, Mashima Y, Watanabe R, Kuwana M, Tsubota K, Ikeda Y, Oguchi Y. Autologous serum eye drops for the treatment of severe dry eye in patients with chronic graft-versus-host disease. Bone Marrow Transplant 2003;31:579-83. 
126. Tananuvat N, Daniell M, Sullivan LJ, Yi Q, McKelvie P, McCarty DJ, Taylor HR. Controlled study of the use of autologous serum in dry eye patients. Cornea 2001;20:802-6.

127. Schornack MM, Pyle J, Patel SV. Scleral lenses in the management of ocular surface disease. Ophthalmology 2014;121:1398-1405.

128. Anitua E, Sánchez M, Orive G, Andía I. Delivering growth factors for therapeutics. Trends Pharmacol Sci. 2008;29:37-41.

129. Anitua E. Plasma rich in growth factors: preliminary results of use in the preparation of future sites for implants. Int J Oral Maxillofac Implants. 1999;14:529535.

130. Anitua E, Sánchez M, Orive G, Andía I. The potential impact of the preparation rich in growth factors (PRGF) in different medical fields. Biomaterials. 2007;28:45514560.

131. Bendinelli P, Matteucci E, Dogliotti G, Corsi MM, Banfi G, Maroni P, Desiderio MA. Molecular basis of anti-inflammatory action of platelet-rich plasma on human chondrocytes: mechanisms of NF-kB inhibition via HGF. J Cell Physiol. 2012;225:757 766.

132. Anitua E, Muruzabal F, Alcalde I, Merayo-Lloves J, Orive G. Plasma rich in growth factors (PRGF-Endoret) stimulates corneal wound healing and reduces haze formation after PRK surgery. Exp Eye Res. 2013;115:153-161.

133. Anitua E, Tejero R, Zalduendo MM, Orive G. Plasma rich in growth factors promotes bone tissue regeneration by stimulating proliferation, migration, and autocrine secretion in primary human osteoblasts. J Periodontol. 2013;84:1180-1190. 
134. Paridaens D, Beekhauis H, van Den Bosch W. Amniotic membrane transplantation in the managments of conjunctival malignant melanoma and primary acquired melanosis with atypia. Br J Ophthalmol 2001;85:658- 661.

135. Terranova VP, Lyall RM. Chemotaxis of human gingival epithelial cells to laminin: a mechanism for epithelial cell apical migration. J Periodontol 1986;57:311.

136. Shimmura S, Shimazaki J, Ohashi Y, Tsubota K. Antiinflammatory effects of amniotic membrane transplantation in ocular surface disorders. Cornea 2001;20:408-13. 137. Kim JC, Tseng S.C.G. The effects on inhibition of corneal neovascularization after human amniotic membrane transplantation in severely damaged rabbit corneas. Korean J Ophthalmol 1995;9:32.

138. Touhami A, Grueterich M, Tseng SC: The role of NGF signaling in human limbal epithelium expanded by amniotic membrane culture. Invest Ophthalmol Vis Sci 2002; 43: 987- 94.

139. Solomon A, Meller D, Prabhasawat P. Amniotic membrane grafts for nontraumatic corneal perforations, descemetoceles, and deep ulcers. Ophthalmology 2002;109:694703.

140. Kim JS, Kim JC, Hahn TW, Park WC. Amniotic membrane transplantation in infectious corneal ulcer. Cornea.2001 Oct;20(7):720- 6 .

141. Hao Y, Ma DH, Hwang DG. Identification of antiangiogenic and antiinflammatory proteins in human amniotic membrane. Cornea 2000;19:348.

142. Gratwohl AA, Moutsopoulos HM, Chused TM, Akizuki M, Wolf RO, Sweet JB, Deisseroth AB. Sjogren-type syndrome after allogeneic bone-marrow transplantation. Ann Intern Med. 1977;87:703-6.

143. Kenyon KR, Tseng SC. Limbal autograft transplantation for ocular surface disorders. Ophthalmology 1989;96:709- 22. 
144. Anderson NG, Regillo C. Ocular manifestations of graft versus host disease.

Curr Opin Ophthalmol 2004;15:503-7.

145. Peris-Martínez C, Menezo JL, Díaz-Llopis M, Aviñó-Martínez JA, Navea-Tejerina

A, Risueño-Reguillo P. Multilayer amniotic membrane transplantation in severe ocular graft versus host disease. Eur J Ophthalmol 2001; 11:183-6.

146. Cosar CB, Cohen EJ, Rapuano CJ. Tarsorrhaphy: clinical experience from a cornea practice. Cornea 2001;20:787-91.

147. Olivieri A, Locatelli F, Zecca M, Sanna A, Cimminiello M, Raimondi R, Gini G, Mordini N, Balduzzi A, Leoni P, Gabrielli A, Bacigalupo A. Imatinib for refractory chronic graft-versus-host disease with fibrotic features. Blood 2009;114:709-18.

148. Ogawa Y, Okamoto S, Kuwana M, Mori T, Watanabe R, Nakajima T, Yamada M, Mashima Y, Tsubota K, Oguchi Y. Successful treatment of dry eye in two patients with chronic graft-versus-host disease with systemic administration of FK506 and corticosteroids. Cornea 2001;20:430-4.

149. Kim SK. Update on ocular graft versus host disease. Curr Opin Ophthalmol. $2006 ; 17: 344-8$.

150. Design and conduct of clinical trials: report of the Clinical Trials Subcommittee of the International Dry Eye WorkShop (2007). Ocul Surf 2007;5:153-62.

151. Friedenstein AJ, Gorskaja JF, Kulagina NN. Fibroblast precursors in normal and irradiated mouse hematopoietic organs. Exp Hematol 1976;4:267-74.

152. Weissman IL. Stem cells: units of development, units of regeneration, and units in evolution. Cell 2000;100:157-68.

153. Friedenstein AJ, Piatetzky S, II, Petrakova KV. Osteogenesis in transplants of bone marrow cells. J Embryol Exp Morphol 1966;16:381-90. 
154. Friedenstein AJ, Petrakova KV, Kurolesova AI, Frolova GP. Heterotopic of bone marrow. Analysis of precursor cells for osteogenic and hematopoietic tissues. Transplantation 1968;6:230-47.

155. Wexler S, Donaldson C, Denning P, Rice C, Bradley B, Hows J. Adult bone marrow is a rich source of human mesenchymal «stem» cells but umbilical cord and mobilized adult blood are not. Br J Haematol 2003;121:368-74.

156. Baksh D, Song L, Tuan RS. Adult mesenchymal stem cells: characterization, differentiation, and application in cell and gene therapy. J Cel Mol Med 2004; 8:301-16. 157. Wagner W, Wein F, Seckinger A, Frankhauser M, Wirkner U, Krause U, Blake J, Schwager C, Eckstein V, Ansorge W, Ho AD. Comparative characteristics of mesenchymal stem cells from human bone marrow, adipose tissue, and umbilical cord blood. Exp Hematol 2005;33:1402-16.

158. Kern S, Eichler H, Stoeve J, Klüter H, Bieback K. Comparative Analysis of Mesenchymal Stem Cells from Bone Marrow, Umbilical Cord Blood, or Adipose Tissue. Stem Cells 2006;24:1294-301.

159. Bieback K, Kern S, Klüter H, Eichler H. Critical parameters for the isolation of mesenchymal stem cells from umbilical cord blood. Stem Cells. 2004;22: 625-34.

160. Sabatini F, Petecchia L, Tavian M, Jodon V, Rossi GA, Brouty- Boye D. Human bronchial fibroblast exhibit a mesenchymal stem cell phenotype and multilineage differentiating potentialities. Lab Invest 2005; 85:962-71.

161. Shi S, Bartold PM, Miura M, Seo BM, Robey PG, Gronthos S. The efficacy of mesenchymal stem cells to regenerate and repair dental structures. Orthod Craniofac Res 2005; 8:191-99.

162. Friedenstein AJ. Marrow stromal fibroblasts. Calcif. Tissue Int 1995; 56 Suppl 1:S17. 
163. Kuznetsov SA, Friedenstein AJ, Robey PG. Factors required for bone marrow stromal fibroblast colony formation in Vitro. Br J Haematol 1997; 97:561-70.

164. Barry FP, Boynton RE, Haynesworth S, Murphy JM, Zaia J. The monoclonal antibody SH-2, raised against human mesenchymal stem cells, recognizes an epitope on endoglin (CD105). Biochem Biophys Res Commun 1999; 265:134-9.

165. Bruder SP, Horowitz MC, Mosca JD, Haynesworth SE.. Monoclonal antibodies reactive with human osteogenic cell surface antigens. Bone 1997; 21:225-35.

166. Bruder SP, Ricalton NS, Boynton RE, Connolly TJ, Jaiswal N, Zaia J, Barry FP. . Mesenchymal stem cell surface antigen SB-10 corresponds to activated leukocyte cell adhesion molecule and is involved in osteogenic differentiation. J Bone Miner Res 1998 13: $655-63$.

167. Haynesworth SE, Baber MA, Caplan AI. Cell surface antigens on human marrowderived mesenchymal cells are detected by monoclonal antibodies. Bone 1992.13:6980.

168. Kobune M, Kawano Y, Ito Y, Chiba H, Nakamura K, Tsuda H, Sasaki K, Dehari H, Uchida H, Honmou O, Takahashi S, Bizen A, Takimoto R, Matsunaga T, Kato J, Kato K, Houkin K, Niitsu Y, Hamada H. Telomerized human multipotent mesenchymal cells can differentiate into hematopoietic and cobblestone area-supporting cells Exp. Hematol 2003;31:715-22.

169. Majumdar MK, Keane-Moore M, Buyaner D, Hardy WB, Moorman MA, McIntosh KR, Mosca JD. Characterization and functionality of cell surface molecules on human mesenchymal stem cells. J Biomed Sci 2003; 10: 228-41.

170. Martin DR, Cox NR, Hathcock TL, Niemeyer GP, Baker HJ. Isolation and characterization of multipotential mesenchymal stem cells from feline bone marrow. Exp Hematol 2002; 30: 879-86. 
171. Mauney JR, Volloch V, Kaplan DL. Role of adult mesenchymal stem cells in bone tissue engineering applications: current status and future prospects. Tissue Eng 2005; 11: 787-802.

172. Pittenger MF, Mackay AM, Beck SC, Jaiswal RK, Douglas R, Mosca JD, Moorman MA, Simonetti DW, Craig S, Marshak DR. Multilineage potential of adult human mesenchymal stem cells. Science 1999; 284:143-7.

173. Prockop DJ. Marrow stromal cells as stem cells for nonhematopoietic tisues. Science $1997 ; 276: 71-4$.

174. Sun S, Guo Z, Xiao X, Liu B, Liu X, Tang PH, Mao N. Isolation of mouse marrow mesenchymal progenitors by a novel and reliable method. Stem Cells 2003; 21:527-35. 175. Dominici M, Le BK, Mueller I. Minimal criteria for defining multipotent mesenchymal stromal cells. The International Society for Cellular Therapy position statement. Cytotherapy 2006;8:315-7.

176. Pittenger MF. Mesenchymal stem cells from adult bone marrow. Methods Mol Biol. 2008;449:27-44.

177. Jiang Y, Jahagirdar BN, Reinhardt RL, Schwartz RE, Keene CD, Ortiz-Gonzalez XR, Reyes M, Lenvik T, Lund T, Blackstad M, Du J, Aldrich S, Lisberg A, Low WC, Largaespada DA, Verfaillie CM. Pluripotency of mesenchymal stem cells derived from adult marrow. Nature 2002;418:41-9.

178. Krampera M, Pasini A, Rigo A, Scupoli MT, Tecchio C, Malpeli G, Scarpa A, Dazzi F, Pizzolo G, Vinante F. HB-EGF/HER-1 signaling in bone marrow mesenchymal stem cells: inducing cell expansion and reversibly preventing multilineage differentiation. Blood 2005;106:59-66.

179. Krampera M, Cosmi L, Angeli R, Pasini A, Liotta F, Andreini A, Santarlasci V, Mazzinghi B, Pizzolo G, Vinante F, Romagnani P, Maggi E, Romagnani S, Annunziato 
F. Role for interferon-gamma in the immunomodulatory activity of human bone marrow mesenchymal stem cells. Stem Cells 2006;24:386-98.

180. Tremain N, Korkko J, Ibberson D, Kopen GC, DiGirolamo C, Phinney DG. MicroSAGE analysis of 2,353 expressed genes in a single cell-derived colony of undifferentiated human mesenchymal stem cells reveals mRNAs of multiple cell lineages. Stem Cells 2001;19:408-18.

181. Chamberlain G, Fox J, Ashton B, Middleton J. Concise review: mesenchymal stem cells: their phenotype, differentiation capacity, immunological features, and potential for homing. Stem Cells 2007;25:2739-49.

182. Post S, Abdallah BM, Bentzon JF, Kassem M. Demonstration of the presence of independent pre-osteoblastic and pre-adipocytic cell populations in bone marrowderived mesenchymal stem cells. Bone 2008;43:32-9.

183. Jackson L, Jones DR, Scotting P, Sottile V. Adult mesenchymal stem cells: differentiation potential and therapeutic applications. J.Postgrad.Med. 2007;53:121-7.

184. Isern J, Mendez-Ferrer S. Stem cell interactions in a bone marrow niche. Curr Osteoporos Rep 2011;9:210-8.

185. Baddoo M, Hill K, Wilkinson R, Gaupp D, Hughes C, Kopen GC, Phinney DG. Characterization of mesenchymal stem cells isolated from murine bone marrow by negative selection. J Cell Biochem 2003;89:1235-49.

186. Meseguer Olmo L, Bernabeu Escaplez A, Vallet Regi M, Aznar Cervantes S, Vicente Ortega V, Alcaraz Baños M et al. Ingeniería tisular del tejido óseo. Diseño y desarrollo de materiales híbridos biológicamente activos basados en vitrocerámicas para sustitución ósea. Revista española de cirugía ortopédica y traumatología. 2010; 54:5968. 
187. Moraleda JM, Blanquer M, Gomez-Espuch J, Iniesta F, Hurtado V, Perez-Espejo MA, Pérez-Espejo MA, Rodríguez-Lozano FJ, Martínez S. Terapia con células madre en enfermedades neurodegenerativas. Rev Hematol Mex 2011;12:144-8.

188. Moraleda Jiménez JM. La terapia celular en enfermedades no hematológicas: ¿sueño o realidad? Rev Hematol Mex 2011;12:239-41.

189. Insausti CL, Blanquer M, Majado MJ, Insausti A, Moraleda JM. Utilidad terapéutica potencial de las células madre de la membrana amniótica. Rev Hematol Mex 2011;11:276-86.

190. Alcaraz A, Mrowiec A, Insausti CL, García-Vizcaíno EM, Ruiz-Canada C, LópezMartínez MC, Moraleda JM, Nicolás FJ.. Autocrine TGF-beta induces epithelial to mesenchymal transition in human amniotic epithelial cells. Cell Transplant $2013 ; 22: 1351-67$.

191. Aznar-Cervantes S, Roca MI, Martinez JG, Meseguer-Olmo L, Cenis JL, Moraleda JM, Otero TF. Fabrication of conductive electrospun silk fibroin scaffolds by coating with polypyrrole for biomedical applications. Bioelectrochemistry 2012;85:36-43.

192. Blanquer M, Moraleda J, Iniesta F, Gómez-Espuch J, Meca-Lallana J, Ramón Villaverde R, Pérez-Espejo MA, Ruíz-López FJ, García Santos JM, Bleda P, Izura V, Sáez M, De Mingo P, Vivancos L, Carles R, Jiménez J, Hernández J, Guardiola J, Torres Del Rio S, Antúnez C, De La Rosa P, Majado MJ, Sánchez-Salinas A, López J, Martínez S. Bone marrow stem cell transplantation in amyotrophic lateral sclerosis: technical aspects and preliminary results from a clinical trial. Methods Find Exp Clin Pharmacol 2010;32:31-7.

193. Blanquer M, Perez-Espejo MA, Martinez-Lage JF, Iniesta F, Martinez S, Moraleda JM. A surgical technique of spinal cord cell transplantation in amyotrophic lateral sclerosis. J Neurosci Methods 2010;191:255-7. 
194. Blanquer M, Moraleda J, Iniesta F, Gómez-Espuch J, Meca-Lallana J, Ramón Villaverde R, Pérez-Espejo MA, Ruíz-López FJ, García Santos JM, Bleda P, Izura V, Sáez M, De Mingo P, Vivancos L, Carles R, Jiménez J, Hernández J, Guardiola J, Torres Del Rio S, Antúnez C, De La Rosa P, Majado MJ, Sánchez-Salinas A, López J, Martínez S. Neurotrophic bone marrow cellular nests prevent spinal motoneuron degeneration in amyotrophic lateral sclerosis patients: a pilot safety study. Stem Cells 2012;30:1277-85. 195. Bueno C, Ramirez C, Rodriguez-Lozano FJ, Tabares-Seisdedos R, Rodenas M, Moraleda JM. Human adult periodontal ligament-derived cells integrate and differentiate after implantation into the adult mammalian brain. Cell Transplant 2013;22:2017-28.

196. García Santos JM, Blanquer M, Torres del Río S, Iniesta F, Espuch JG, PérezEspejo MÁ, Martínez S, Moraleda JM.. Acute and chronic MRI changes in the spine and spinal cord after surgical stem cell grafting in patients with definite amyotrophic lateral sclerosis: post-infusion injuries are unrelated with clinical impairment. Magn Reson Imaging 2013;31:1298-308.

197. Gonzálvez-García M, Rodríguez-Lozano FJ, Villanueva V, Segarra-Fenoll D, Rodríguez-González MA, Oñate-Sánchez R, Blanquer M, Meseguer-Olmo L, Moraleda JM. Mesenchymal stem cells and bisphosphonate-related osteonecrosis of the jaw: the future? Oral Dis 2012;18:823-4.

198. Gonzálvez-García M, Rodríguez-Lozano FJ, Villanueva V, Segarra-Fenoll D, Rodríguez-González MA, Oñate-Sánchez R, Blanquer M, Moraleda JM. Cell therapy in bisphosphonate-related osteonecrosis of the jaw. J Craniofac Surg 2013;24:226-8.

199. Insausti CL, Alcaraz A, García-Vizcaíno EM, Mrowiec A, López-Martínez MC, Blanquer M, Piñero A, Majado MJ, Moraleda JM, Castellanos G, Nicolás FJ. Amniotic 
membrane induces epithelialization in massive posttraumatic wounds. Wound Repair Regen 2010;18:368-77.

200. Insausti CL, Blanquer M, Bleda P, Iniesta P, Majado MJ, Castellanos G, Moraleda JM. The amniotic membrane as a source of stem cells. Histol Histopathol 2010;25:91-8. 201. Insausti CL, Blanquer MB, Olmo LM, López-Martínez MC, Ruiz XF, Lozano FJ, Perianes VC, Funes C, Nicolás FJ, Majado MJ, Jiménez JM. Isolation and characterization of mesenchymal stem cells from the fat layer on the density gradient separated bone marrow. Stem Cells Dev 2012;21:260-72.

202 Moraleda JM, Blanquer M, Bleda P, Iniesta P, Ruiz F, Bonilla S, Cabanes C, Tabares L, Martinez S. Adult stem cell therapy: dream or reality? Transpl Immunol 2006;17:74-7.

203. Pastor D, Viso-León MC, Jones J, Jaramillo-Merchán J, Toledo-Aral JJ, Moraleda JM, Martínez S. Comparative effects between bone marrow and mesenchymal stem cell transplantation in GDNF expression and motor function recovery in a motorneuron degenerative mouse model. Stem Cell Rev 2012;8:445-58.

204. Pastor D, Viso-León MC, Botella-López A, Jaramillo-Merchan J, Moraleda JM, Jones J, Martínez S. Bone marrow transplantation in hindlimb muscles of motoneuron degenerative mice reduces neuronal death and improves motor function. Stem Cells Dev. 2013;22:1633-44.

205. Rodriguez-Lozano FJ, Moraleda JM. Use of dental stem cells in regenerative dentistry: a possible alternative. Transl Res. 2011;158:385-6.

206. Rodríguez-Lozano FJ, Bueno C, Insausti CL, Meseguer L, Ramírez MC, Blanquer M, Marín N, Martínez S, Moraleda JM... Mesenchymal stem cells derived from dental tissues. Int Endod J. 2011;44:800-6. 
207. Rodriguez-Lozano FJ, Insausti CL, Meseguer L, Ramirez MC, Martinez S, Moraleda JM. Tissue engineering with dental pulp stem cells: isolation, characterization, and osteogenic differentiation. J Craniofac Surg. 2012;23: 571-5.

208. Rodríguez-Lozano FJ, Insausti CL, Iniesta F, Blanquer M, Ramírez MD, Meseguer L, Meseguer-Henarejos AB, Marín N, Martínez S, Moraleda JM. Mesenchymal dental stem cells in regenerative dentistry. Med Oral Patol Oral Cir Bucal. 2012;17:1062-7. 209. Rodriguez-Lozano FJ, Serrano-Belmonte I, Perez Calvo JC, Coronado-Parra MT, Bernabeu-Esclapez A, Moraleda JM. Effects of two low-shrinkage composites on dental stem cells (viability, cell damaged or apoptosis and mesenchymal markers expression). J Mater Sci Mater Med. 2013;24:979-88.

210. Rodriguez Lozano FJ, Moraleda JM. Mesenchymal dental pulp stem cells: a new tool in sinus lift. J Craniofac Surg. 2011;22:774-5.

211. Pérez-Simon JA, López-Villar O, Andreu EJ, Rifón J, Muntion S, Diez Campelo M, Sánchez-Guijo FM, Martinez C, Valcarcel D, Cañizo CD. Mesenchymal stem cells expanded in vitro with human serum for the treatment of acute and chronic graft-versushost disease: results of a phase I/II clinical trial. Haematologica 2011;96:1072-6.

212. Pérez-Ilzarbe M, Díez-Campelo M, Aranda P, Tabera S, Lopez T, del Cañizo C, Merino J, Moreno C, Andreu EJ, Prósper F, Pérez-Simón JA. Comparison of ex vivo expansion culture conditions of mesenchymal stem cells for human cell therapy. Transfusion 2009;49:1901-10.

213. Sánchez PL, Sánchez-Guijo FM, Villa A, del Cañizo C, Arnold R, San Román JA, Fernández-Avilés F. Launching a clinical program of stem cell therapy for cardiovascular repair. Nat Clin Pract Cardiovasc Med 2007;4 Suppl 1:S123-S129. 
214. Bartholomew A, Sturgeon C, Siatskas M, Ferrer K, McIntosh K, Patil S, Hardy W, Devine S, Ucker D, Deans R, Moseley A, Hoffman R. Mesenchymal stem cells suppress lymphocyte proliferation in vitro and prolong skin graft survival in vivo. Exp Hematol 2002;30:42-8.

215. Di Nicola M, Carlo-Stella C, Magni M, Milanesi M, Longoni PD, Matteucci P, Grisanti S, Gianni AM.. Human bone marrow stromal cells suppress T-lymphocyte proliferation induced by cellular or nonspecific mitogenic stimuli. Blood 2002;99:383843.

216. Tse WT, Pendleton JD, Beyer WM, Egalka MC, Guinan EC. Suppression of allogeneic T-cell proliferation by human marrow stromal cells: implications in transplantation. Transplantation 2003;75:389-97.

217. Le Blanc K, Rasmusson I, Sundberg B, Götherström C, Hassan M, Uzunel M, Ringdén O.Treatment of severe acute graft-versus-host disease with third party haploidentical mesenchymal stem cells. Lancet 2004;363:1439-41.

218. Wolfman NM, Hattersley G, Cox K, Celeste AJ, Nelson R, Yamaji N, Dube JL, DiBlasio-Smith E, Nove J, Song JJ, Wozney JM, Rosen V. Ectopic induction of tendon and ligament in rats by growth and differentiation factors 5, 6, and 7, members of the TGF-beta gene family. J Clin Invest 1997;100:321-30.

219. Altman GH, Horan RL, Martin I, Farhadi J, Stark PR, Volloch V, Richmond JC, Vunjak-Novakovic G, Kaplan DL. Cell differentiation by mechanical stress. FASEB J $2002 ; 16: 270-2$.

220. Caplan AI. Review: mesenchymal stem cells: cell-based reconstructive therapy in orthopedics. Tissue Eng 2005;11:1198-211.

221. Deans RJ, Moseley AB. Mesenchymal stem cells: biology and potential clinical uses. Exp Hematol 2000;28:875-84. 
222. Horwitz EM. MSC: a coming of age in regenerative medicine. Cytotherapy 2006;8:194-5.

223. Koç ON, Gerson SL, Cooper BW, Dyhouse SM, Haynesworth SE, Caplan AI, Lazarus HM. Rapid hematopoietic recovery after coinfusion of autologous-blood stem cells and culture-expanded marrow mesenchymal stem cells in advanced breast cancer patients receiving high-dose chemotherapy. J Clin Oncol 2000;18:307-16.

224. Pérez RL, Pérez-Simón JA, Caballero-Velazquez T, Flores T, Carrancio S, Herrero C, Blanco B, Gutiérrez-Cosio S, Cañete-Campos C, Cruz González F, San-Miguel JF, Hernández-Galilea E, Sánchez-Abarca I. Limbus damage in ocular graft-versus-host disease. Biol Blood Marrow Transplant 2011;17:270-273.

225. Sánchez-Abarca LI, Hernández-Galilea E, Lorenzo R, Herrero C, Velasco A, Carrancio S, Caballero-Velázquez T, Rodríguez-Barbosa JI, Parrilla M, Del Cañizo C, San Miguel J, Aijón J, Pérez-Simón JA. Human bone marrow stromal cells differentiate into corneal tissue and prevent ocular graft-versus-host disease in mice. Cell Transplant 2015;24:2423-33.

226. Carrancio S, Blanco B, Romo C, Muntion S, Lopez-Holgado N, Blanco JF, Briñon JG, San Miguel JF, Sanchez-Guijo FM, del Cañizo MC. Bone marrow mesenchymal stem cells for improving hematopoietic function: An in vitro and in vivo model. Part 2: Effect on bone marrow microenvironment. PLoS One 2011; 6: e26241.

227. Carrancio S, Romo C, Ramos T, Lopez-Holgado N, Muntion S, Prins HJ, Martens AC, Briñón JG, San Miguel JF, del Cañizo MC, Sanchez-Guijo F. Effects of MSCcoadministration and route of delivery on cord blood hematopoietic stem cell engraftment. Cell Transplant 2013; 22: 1171-83. 
228. Le Blanc K, Frassoni F, Ball L, Locatelli F, Roelofs H, Lewis I. Mesenchymal stem cells for treatment of steroid-resistant, severe, acute graft-versus-host disease: a phase II study. Lancet. 2008;371:1579-1586.

229. Kaipe H, Erkers T, Sadeghi B, Ringden O. Stromal cells-are they really useful for GVHD? Bone Marrow Transplant. 2014;49:737-743.

230. Kuzmina LA, Petinati NA, Parovichnikova EN, Lubimova LS, Gribanova EO, Gaponova TV. Multipotent Mesenchymal Stromal Cells for the Prophylaxis of Acute Graft-versus-Host Disease-A Phase II Study. Stem Cells Int. 2012;2012:968213.

231. Trattler W, Kaiser PK, Friedman NJ. Pharmacology en Review of Ophthalmology. $2^{\text {nd }}$ Edition. 2012. Elsevier Saunders. UK.

232. Abla O, Friedman J, Doyle J. Performing bone marrow aspiration and biopsy in children: recommended guidelines. Paediatrics and Child Health.2008; 13(6): 499-501. 233. S.Gronthos,A.C.Zannettino,S.J.Hayetal. Molecular and cellular characterisation of highly purified stromal stem cells derived from human bone marrow. Journal of Cell Science. 2003; 116(9):1827-35.

234. Sen A, Lea-Currie YR, Sujkowska B. Adipogenic potential of human adipose derived stromal cells from multiple donors is heterogeneous. Journal of Cellular Biochemistry. 2001. 81 (2):312-19.

235. Zuk PA, Zhu M, Ashjian P. Human adipose tissue is a source of multipotent stem cells. Molecular Biology of the Cell. 2002; 13 (12):4279-95.

236. H. Mizuno, "Adipose-derived stem cells for tissue repair and regeneration: ten years of research and a literature review," Journal of Nippon Medical School. 2009;76(2):56-66.

237. Furlani D, Ugurlucan M, Ong L, Bieback K, Pittermann E, Westien I, Wang W, Yerebakan C, Li W, Gaebel R, Li RK, Vollmar B, Steinhoff G, Ma N. Is the 
intravascular administration of mesenchymal stem cells safe? Mesenchymal stem cells and intravital microscopy. Microvasc Res. 2009 May;77(3):370-6.

238. Radley JM, Ellis S, Palatsides M, Williams B, Bertoncello I. Ultrastructure of primitive hematopoietic stem cells isolated using probes of functional status. Exp Hematol. 1999 Feb;27(2):365-9.

239. Walczak P, Zhang J, Gilad AA, Kedziorek DA, Ruiz-Cabello J, Young RG, Pittenger MF, van Zijl PC, Huang J, Bulte JW. Dual-modality monitoring of targeted intraarterial delivery of mesenchymal stem cells after transient ischemia. Stroke. 2008;39(5):1569-74.

240. Toupet K, Maumus M, Luz-Crawford P, Lombardo E, Lopez-Belmonte J, van Lent P, Garin MI, van den Berg W, Dalemans W, Jorgensen C, Noël D. Survival and biodistribution of xenogenic adipose mesenchymal stem cells is not affected by the degree of inflammation in arthritis. PLoS One. 2015 Jan 5;10(1):e0114962.

241. Suzuki K, Sun R, Origuchi M, Kanehira M, Takahata T, Itoh J, Umezawa A, Kijima H, Fukuda S, Saijo Y. Mesenchymal stromal cells promote tumor growth through the enhancement of neovascularization. Mol Med. 2011;17(7-8):579-87.

242. Bruno S, Grange C, Deregibus MC, Calogero RA, Saviozzi S, Collino F, Morando L, Busca A, Falda M, Bussolati B, Tetta C, Camussi G. Mesenchymal stem cell-derived microvesicles protect against acute tubular injury. J Am Soc Nephrol. 2009; 20(5):105367.

243. Yu B, Zhang X, Li X. Exosomes derived from mesenchymal stem cells. Int J Mol Sci. $2014 ; 15(3): 4142-57$.

244. Akyurekli C, Le Y, Richardson RB, Fergusson D, Tay J, Allan DS. A systematic review of preclinical studies on the therapeutic potential of mesenchymal stromal cellderived microvesicles. Stem Cell Rev. 2015;11(1):150-60. 
245. Zhang Y, Chopp M, Zhang ZG, Katakowski M, Xin H, Qu C, Ali M, Mahmood A, Xiong Y. Systemic administration of cell-free exosomes generated by human bone marrow derived mesenchymal stem cells cultured under 2D and 3D conditions improves functional recovery in rats after traumatic brain injury. Neurochem Int. 2016 Aug 15. pii: S0197-0186(16)30251-0.

246. Kordelas L, Rebmann V, Ludwig AK, Radtke S, Ruesing J, Doeppner TR, Epple M, Horn PA, Beelen DW, Giebel B. MSC-derived exosomes: a novel tool to treat therapy-refractory graft-versus-host disease. Leukemia. 2014; 28(4):970-3.

247. Allers C, Lasala GP, Minguell JJ. Presence of osteoclast precursor cells during ex vivo expansion of bone marrow-derived mesenchymal stem cells for autologous use in cell therapy. Cytotherapy. 2014 Apr;16(4):454-9.

248. Fernández M, Simon V, Herrera G, Cao C, Del Favero H, Minguell JJ. Detection of stromal cells in peripheral blood progenitor cell collections from breast cancer patients. Bone Marrow Transplant 1997;20:265-71.

249. Cooke KR, Kobzik L, Martin TR, Brewer J, Delmonte J, Crawford JM, Ferrara JL. An experimental model of idiopathic pneumonia syndrome after bone marrow transplantation: I. The roles of minor H antigens and endotoxin. Blood 1996;88:3230-9. 250. Kaneko K, Yano M, Yamano T, Tsujinaka T, Miki H, Akiyama Y, Taniguchi M, Fujiwara Y, Doki Y, Inoue M, Shiozaki H, Kaneda Y, Mon M. Detection of peritoneal micrometastases of gastric carcinoma with green fluorescent protein and carcinoembryonic antigen promoter. Cancer Res 2001;61:5570-4.

251. Wilson T, Hastings JW. Bioluminescence. Annu.Rev Cell Dev Biol 1998;14:197-230. 252. Wu JC, Sundaresan G, Iyer M, Gambhir SS. Noninvasive optical imaging of firefly luciferase reporter gene expression in skeletal muscles of living mice. Mol Ther 2001;4:297-306. 
253. Blesch A. Lentiviral and MLV based retroviral vectors for ex vivo and in vivo gene transfer. Methods 2004;33:164-172.

254. Vashisht S, Singh S. Evaluation of Phenol Red Thread test versus Schirmer test in dry eyes: A comparative study. Int J Appl Basic Med Res. 2011; 1:40-2.

255. Khanal S, Tomlinson A, McFadyen A, Diaper C, Ramaesh K. Dry eye diagnosis. Invest Ophthalmol Vis Sci 2008;49:1407-14.

256. Delaleu N, Jonsson MV, Appel S, Jonsson R. New concepts in the pathogenesis of Sjogren's syndrome. Rheum Dis Clin North Am 2008;34:833-45.

257. Stapleton F, Garrett Q, Chan C, Craig JP. The Epidemiology of Dry Eye Disease. Heidelberg: Springer; 2015.

258. Perez VL, Barsam A, Duffort S, Urbieta M, Barreras H, Lightbourn C, Komanduri KV, Levy RB. Novel Scoring Criteria for the Evaluation of Ocular Graftversus-Host Disease in a Preclinical Allogeneic Hematopoietic Stem Cell Transplantation Animal Model. American Society for Blood and Marrow Transplantation 2016: 1083-8791.

259. Knop E, Korb DR, Blackie CA, Knop N. The lid margin is an underestimatedstructure for preservation of ocular surface health and development of dry eye disease. Dev Ophthalmol 2010;45:108-122.

260. Ogawa Y, Shimmura S, Dogru M, Tsubota K. Immune processes and pathogenic fibrosis in ocular chronic graft-versus-host disease and clinical manifestations after allogeneic hematopoietic stem cell transplantation. Cornea 2010; 29:S68-77.

261. Y. Ogawa; K. Yamazaki; D. Murat; E. Goto; S. Shimmura; H. Fujishima; M. Kuwana; S. Okamoto; Y. Kawakami; K. Tsubota. Pathogenic Fibrosis and Inflammation of Conjunctival Chronic Graft-Versus-Host Disease. Invest Ophthalmol Vis Sci 2006;47, 255. 
262. Yaguchi S.; Ogawa Y; Shinmura Y.; Tsubota K. Lacrimal Gland Inflammation And Fibrosis In Murine Model Of Ocular Graft Versus Host Disease. Invest Ophthalmol Vis Sci 2011;52, 3720.

263. Barraquer RI, De Toledo MI, Torres E. Distrofia y Degeneraciones Corneales. Barcelona; 2004.

264. Hare, J.M. Comparison of allogeneic vs autologous bone marrow-derived mesenchymal stem cells delivered by transendocardial injection in patients with ischemic cardiomyopathy: the POSEIDON randomized trial. J Am Med Assoc 2012; $308,2369-79$.

265. Zhang Z, Lin H, Shi M, Xu R, Fu J, Lv J, Chen L, Lv S, Li Y, Yu S, Geng H, Jin L, Lau GK, Wang FS. Human umbilical cord mesenchymal stem cells improve liver function and ascites in decompensated liver cirrhosis patients. J Gastroenterol Hepatol 2012; 27: 112-20.

266. Sun L, Wang D, Liang J, Zhang H, Feng X, Wang H, Hua B, Liu B, Ye S, Hu X, Xu W, Zeng X, Hou Y, Gilkeson GS, Silver RM, Lu L, Shi S. Umbilical cord mesenchymal stem cell transplantation in severe and refractory systemic lupus erythematosus. Arthritis Rheum 2010; 62: 2467-75.

267. Tyndall A, Van Laar JM. Stem cells in the treatment of inflammatory arthritis. Best Pract Res Clin Rheumatol 2010;24: 565-74.

268. Prockop DJ, Kota DJ, Bazhanov N, Reger RL. Evolving paradigms for repair of tissues by adult stem/progenitor cells (MSCs). J Cell Mol Med 2010; 14, 2190-9.

269. von Bahr L, Batsis I, Moll G, Hägg M, Szakos A, Sundberg B, Uzunel M, Ringden O, Le Blanc K. Analysis of tissues following mesenchymal stromal cell therapy in humans indicates limited long-term engraftment and no ectopic tissue formation. Stem Cells. 2012; 30: 1575-8. 
270. Tomita S, Li RK, Weisel RD, Mickle DA, Kim EJ, Sakai T, et al. Autologous transplantation of bone marrow cells improves damaged heart function. Circulation 1999;100: 247-56.

271. Shake JG, Gruber PJ, Baumgartner WA, Senechal G, Meyers J, Redmond JM. Mesenchymal stem cell implantation in a swine myocardial infarct model: engraftment and functional effects. Ann Thorac Surg 2002;73:1919-25.

272. Prockop DJ, Oh JY. Mesenchymal stem/stromal cells (MSCs): role as guardians of inflammation. Mol Ther 2012; 20: 14-20.

273. Wang Y, Chen X, Cao W, Shi Y. Plasticity of mesenchymal stem cells in immunomodulation: pathological and therapeutic implications. Nat Immunology 2014; 15: 1009-16.

274. Bai, L. y cols. Hepatocyte growth factor mediates mesenchymal stem cell-induced recovery in multiple sclerosis models. Nat Neurosci 2012;15: 862-70.

275. Ma, S. y cols. Immunobiology of mesenchymal stem cells. Cell Death Differ 2014; 21: 216-25.

276. Ranganath SH, Levy O, Inamdar MS, Karp JM. Harnessing the mesenchymal stem cell secretome for the treatment of cardiovascular disease. Stem Cell 2012;10: $244-58$.

277. Bernardo ME, Fibbe WE. Mesenchymal stromal cells: sensors and switchers of inflammation. Stem Cell. 2013; 13: 392-402.

278. Ren G, Zhang L, Zhao X, Xu G, Zhang Y, Roberts AI, Zhao RC, Shi Y. Mesenchymal stem cell-mediated immunosuppression occurs via concerted action of chemokines and nitric oxide. Stem Cell 2008; 2: 141-50.

279. Sudres M, Norol F, Trenado A, Grégoire S, Charlotte F, Levacher B, Lataillade JJ, Bourin P, Holy X, Vernant JP, Klatzmann D, Cohen JL. Bone marrow mesenchymal 
stem cells suppress lymphocyte proliferation in vitro but fail to prevent graft-versushost disease in mice. J Immunol 2006; 176: 7761-7.

280. Rafei M, Campeau PM, Aguilar-Mahecha A, Buchanan M, Williams P, Birman E, Yuan S, Young YK, Boivin MN, Forner K, Basik M, Galipeau J. Mesenchymal stromal cells ameliorate experimental autoimmune encephalomyelitis by inhibiting CD4 Th17 T cells in a CC chemokine ligand 2-dependent manner. J Immunol. 2009; 182: 59946002.

281. Constantin G, Marconi S, Rossi B, Angiari S, Calderan L, Anghileri E, Gini B, Bach SD, Martinello M, Bifari F, Galiè M, Turano E, Budui S, Sbarbati A, Krampera M, Bonetti B.Adipose-derived mesenchymal stem cells ameliorate chronic experimental autoimmune encephalomyelitis. Stem Cells 2009; 27: 2624-35.

282. D’Souza N, Rossignoli F, Golinelli G, Grisendi G, Spano C, Candini O, Osturu S, Catani S, Paolucci P, Horwitz EH, Dominici M. Mesenchymal stem/stromal cells as a delivery platform in cell and gene therapies. BMC Medicine 2015; 13:186.

283. Li W. Mesenchymal stem cells: a double-edged sword in regulating immune responses. Cell Death Differ 19, 1505-1513 (2012).

284. Chan JL. Antigen-presenting property of mesenchymal stem cells occurs during a narrow window at low levels of interferon- $\gamma$. Blood 2006; 107: 4817-24.

285. François M. Mesenchymal stromal cells cross-present soluble exogenous antigens as part of their antigen-presenting cell properties. Blood 2009; 114: 2632-8.

286. Li MO, Flavell RA. Contextual regulation of inflammation: a duet by transforming growth factor- $\beta$ and interleukin-10. Immunity 2008; 28: 468-476.

287. Li Z, Kupcsik L, Yao SJ, Alini M, Stoddart MJ. Mechanical load modulates chondrogenesis of human mesenchymal stem cells through the TGF- $\beta$ pathway. J Cell Mol Med 2010; 14: 1338-46. 
288. Crane JL, Cao X. Bone marrow mesenchymal stem cells and TGF-beta signaling in bone remodeling. J Clin Invest 2014; 124: 466-72.

289. Xu C. TGF- $\beta$ promotes immune responses in the presence of mesenchymal stem cells. J. Immunol. 2014; 192: 103-109.

290. Renner P. Mesenchymal stem cells require a sufficient, ongoing immune response to exert their immunosuppressive function. Transplant Proc 2009; 41: 2607-11.

291. Akiyama K, Chen C, Wang D, Xu X, Qu C, Yamaza T, Cai T, Chen W, Sun L, Shi S. Mesenchymal-stem-cell-induced immunoregulation involves FAS-ligand-/FASmediated T cell apoptosis. Stem Cell 2012; 10: 544-55.

292. Burr SP, Dazzi F, Garden OA. Mesenchymal stromal cells and regulatory T cells: the Yin and Yang of peripheral tolerance? Immunol. Cell Biol. 2013; 91: 12-8.

293. Ren G. Species variation in the mechanisms of mesenchymal stem cell-mediated immunosuppression. Stem Cells 2009; 27: 1954-1962. 


